JONAS DIAS DE SOUZA

\title{
ECÚMENO, PAISAGEM E DIREITO AMBIENTAL: PROBLEMÁTICAS GEOGRÁFICAS DA DOUTRINA E DA JURISPRUDÊNCIA
}

\author{
Versão Corrigida \\ (Versão original encontra-se na unidade que aloja \\ o Programa de Pós-graduação) \\ Tese apresentada à Universidade de São Paulo, \\ como requisito parcial, à obtenção do título de \\ Doutor em Geografia. \\ Área de Concentração: Geografia Física \\ Orientador: Prof. Dr. Adilson Avansi de Abreu
}


Autorizo a reprodução e divulgação total ou parcial deste trabalho, por qualquer meio convencional ou eletrônico, para fins de estudo e pesquisa, desde que citada a fonte. 
Nome: SOUZA, Jonas Dias de

Título: Ecúmeno, paisagem e Direito Ambiental: problemáticas geográficas da doutrina e da jurisprudência

Tese apresentada à Universidade de São Paulo, como requisito parcial, à obtenção do título de Doutor em Geografia.

Aprovado em:

Banca Examinadora

Prof. Dr. Instituição:

Julgamento: Assinatura::

Prof. Dr. Instituição:

Julgamento: Assinatura::

Prof. Dr. Instituição:

Julgamento: Assinatura::

Prof. Dr. Instituição:

Julgamento: Assinatura::

Prof. Dr. Instituição:

Julgamento: Assinatura:: 
Para meu pai, Jorge José de Souza, e para minha mãe, Ana Dias de Souza. 


\section{AGRADECIMENTOS}

Ao meu orientador, professor Doutor Adilson Avansi de Abreu, que me acompanha desde os primeiros passos da pesquisa na graduação. Agradeço a confiança depositada em mim durante esses anos de estudo, às orientações, conselhos e incentivos para a realização das pesquisas.

A todos os professores e funcionários do departamento de Geografia da Universidade de São Paulo, pelas estimulantes aulas e pelo apoio acadêmico recebido

Aos professores, funcionários e alunos da Universidade Federal do Tocantins Campus Porto Nacional - com quem dividi momentos únicos e inesquecíveis da vida. Agradeço ao colegiado de Geografia pela fraternal acolhida e apoio para desenvolvimento da pesquisa e pelas orientações na minha primeira experiência profissional acadêmica; ao pessoal da limpeza, manutenção, jardinagem, terceirizados da segurança, os quais tornaram um pouco portuense meu coração; agradeço aos alunos indígenas Xerente cuja companhia em Porto Nacional fez meus dias mais felizes.

Aos professores, funcionários e alunos da Universidade do Estado do Amazonas Centro de Estudos Superiores de Tabatinga. Ao professor Reginaldo Conceição da Silva e ao discente Jailson Franco Aguiar, os primeiros a me acolherem na cidade.

Aos casais e amigos, Matheus Nani Costa, Fernanda Mercedes Morales Diaz, Daniel Watanabe e Camila Torres e Cibelle Pereira Soares pelas incontáveis acolhidas em suas residências e apoio incondicional nas horas difíceis da pesquisa e da vida.

Ao grupo de capoeira Filhos do Bonfim e Capoeira Raízes, em especial nas figuras do Mestre Sena, Mestre Du, Mestre Banana, Mestre Gamela e Contramestre Penugem.

E por último, mas não menos importante, aos meus pais e familiares que incondicionalmente apoiaram minhas escolhas e sem os quais não teria conseguido chegar até aqui. A eles, meus sinceros agradecimentos. 


\section{RESUMO}

SOUZA, Jonas Dias de. Ecúmeno, paisagem e Direito Ambiental: problemáticas geográficas da doutrina e da jurisprudência. 2017. 207 f. Tese (Doutorado em Geografia Física) - Faculdade de Filosofia, Letras e Ciências Humanas da Universidade de São Paulo, São Paulo, 2017.

As degradações ambientais enfrentadas no mundo contemporâneo têm suscitado normas de proteção e controle das atividades humanas em função da preservação do meio ambiente. No Brasil, o Direito Ambiental consolida-se na década de 1980, principalmente a partir da Constituição Federal de 1988, embora desde a colônia existissem normas que protegessem a natureza. Esta tese de doutorado analisa e problematiza geograficamente o Direito Ambiental brasileiro, tendo por fundamento, de um lado, a teoria do ecúmeno, mediance e paisagem desenvolvida por Augustin Berque e, de outro, a teoria tridimensional do Direito, elaborada por Miguel Reale. Como ramo do Direito que visa regulamentar a relação do homem com o meio ambiente, objetivou-se caracterizar como o meio ambiente e seus elementos constitutivos são definidos no Direito Ambiental e qual relação a sociedade deve ter com a natureza para, posteriormente, confrontá-los com a existência do homem no mundo enquanto existência ecumenal. Metodologicamente, por meio de pesquisa indutiva exploratória no universo da doutrina brasileira de Direito Ambiental e da jurisprudência do Tribunal de Justiça de Minas Gerais, os princípios e conceitos "ambientais" foram sistematizados e analisados conforme suas definições e entendimentos predominantes. Os doutrinadores foram selecionados a partir das ementas da disciplina de Direito Ambiental do curso de Direito de universidades do sul e sudeste brasileiro. A pesquisa na jurisprudência do tribunal mineiro concentrouse nos termos paisagem e dano moral ambiental. O processo judicial a respeito da construção do Paço de Poços de Caldas também foi analisado para complementar a análise doutrinária e jurisprudencial, anteriormente realizadas. Na discussão dos resultados, debate-se a naturalização do meio ambiente operada pelo Direito Ambiental em detrimento da dimensão técnica e simbólica da relação humana com a superfície terrestre e o meio ambiente enquanto totalidade natural como forma de garantir o princípio isonômico do Direito. Discute-se, também, a construção de uma narrativa jurídica do mundo enquanto universo de significação da hermenêutica e aplicação do Direito e a composição jurídica da mediance e da paisagem.

Palavras-chave: Ecúmeno. Paisagem. Direito Ambiental. Paço Municipal de Poços de Caldas. Geografia do Direito. 


\begin{abstract}
SOUZA, Jonas Dias de. Ecumene, landscape and Environmental Law: geographic issues of theory and jurisprudence. 2017. $200 \mathrm{f}$. Tese (Doutorado) - Faculdade de Filosofia, Letras e Ciências Humanas da Universidade de São Paulo, São Paulo, 2017.

The environment problems faced by society today has demanded rules for controlling humans activities due to environmental protection. In Brazil, there are rules to protect nature since colonial times, but environmental law has consolidated itself at 1980's, especially from the Federal Constitution of 1988. This work analyses and pose geographical problems of Brazilian environmental law based on the theory of ecumene, mediance and landscape developed by Augustin Berque, for one hand, and, for other hand, the theory of three-dimensionality of law, elaborated by Miguel Reale. Regulating relation between man and environment, the definition of environment and its constitutive elements and how relation man-environment should be are characterized and after compared with the ecumenal existence of man. Methodologically, based on inductive-exploratory research on environmental law Brazilian theory and on the jurisprudence of Minas Gerais Justice Court, "environmental" principles and concepts were systematized and described fowling its dominant definition and understanding. The authors were selected from the environmental law discipline program of south and south-east universities of Brazil. The research at Minas Gerais jurisprudence used the key-words landscape and moral environmental damage. At last, the case involving the construction of a Civil Center (Paço Municipal) was also analysed to complete the debate realized. The results show the naturalization of environment as it is described by environmental law theory over the symbolic and technical relation of man and earth surface; it also discuss the environment taken as natural totality as a way to maintain the principle of isonomy of law, the construction of a juridical narrative of the word influentiating interpretation and application of law. At last, it is analysed juridical composition of mediance and landscape.
\end{abstract}

Key-words: Ecumene. Landscape. Environmental Law. Paço Municipal de Poços de Caldas. Geography of Law. 


\section{LISTA DE FIGURAS}

Figura 1 - Imagem de satélite de parte da sub-bacia do ribeirão das Vargens 175

Figura 2 - Área onde seria implantado o Paço Municipal.

Figura 3 - Silvicultura e plantação de aveia.

Figura 4 - Vista parcial da sub-bacia do ribeirão das Vargens 


\section{LISTA DE GRÁFICOS}

Gráfico 1 - Número de ocorrências do termo paisagem na jurisprudência dos

Tribunais de Justiça estaduais por região

Gráfico 2 - Número de ocorrências do termo paisagem na jurisprudência dos

Tribunais de Justiça dos estados da região Sudeste

Gráfico 3 - Número de ocorrências do termo paisagem na jurisprudência dos

Tribunais de Justiça dos estados da região Sul

Gráfico 4 - Número de ocorrências do termo paisagem na jurisprudência dos

Tribunais de Justiça dos estados da região Norte

Gráfico 5 - Número de ocorrências do termo paisagem na jurisprudência dos

Tribunais de Justiça dos estados da região Nordeste

Gráfico 6 - Número de ocorrência do termo paisagem na jurisprudência dos Tribunais de Justiça dos estados da região Centro-Oeste 


\section{LISTA DE MAPAS}

Mapa 1 - Localização geográfica do município de Poços de Caldas/MG ....................137

Mapa 2 - Localização da sub-bacia do ribeirão das Vargens ……………………….....138

Mapa 3 - Zoneamento municipal de 1970 .................................................................. 142

Mapa 4 - Macrozoneamento municipal de Poços de Caldas - 1992 ............................144

Mapa 5 - Zoneamento municipal de Poços de Caldas, 2006 …………........................ 146

Mapa 6 - Lotes vagos no município de Poços de Caldas .............................................. 148

Mapa 7 - Coeficiente de aproveitamento praticado nos lotes em Poços de Caldas 148 Mapa 8 - Uso e ocupação do solo praticado na sub-bacia do ribeirão das Vargens,

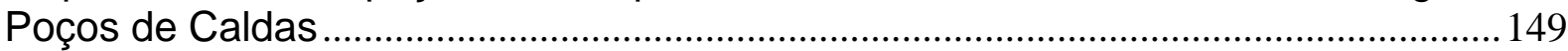




\section{LISTA DE TABELAS}

Tabela 1 - Áreas selecionadas para abrigar o Paço Municipal 151

Tabela 2 - Pontuação para fator distância geográfica média ponderada .....................152 Tabela 3 - Ponderação e pontuação final, considerando custos de desapropriação e construção de vias

Tabela 4 - Ponderação e pontuação final, suprimindo os custos de desapropriação das áreas 4 e 6 . Tabela 5 - Ponderação e pontuação final, suprimindo os custos de desapropriação das áreas 4 e 6 e construção de vias das áreas 1 e 4 


\section{LISTA DE QUADROS}

Quadro 1 - Autores e Obras citados por Universidade 88

Quadro 2 - Autores e Princípios de Direito Ambiental. 91

Quadro 3 - Conceito de Poluição na Legislação Nacional 104

Quadro 4 - Definições Presentes na Lei 9.985/2000 106

Quadro 5 - Espécies de Unidades de Conservação Conforme Lei № 9.985/2000 .. 108 Quadro 6 - Eventos geradores de dano moral ambiental 
1 INTRODUÇÃO

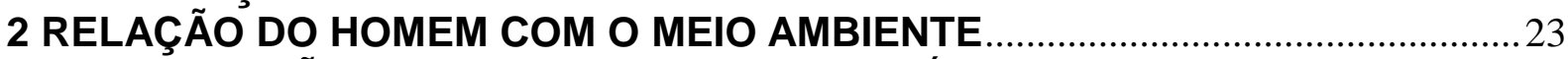

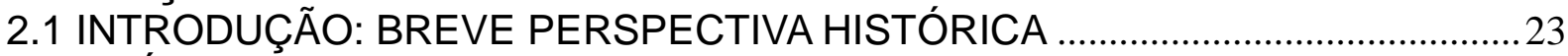

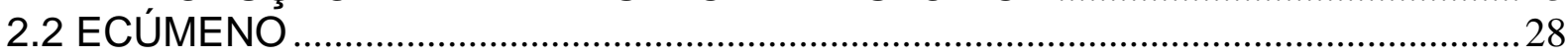

2.2.1 Ecúmeno e crítica à dicotomia homem-natureza ............................................. 30

2.2.2 Ecúmeno, mediance e ecosimbolicidade .......................................................... 35

2.2.3 Mediance e ideologia geográfica...................................................................... 36

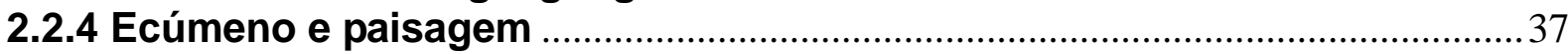

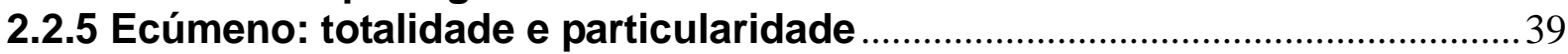

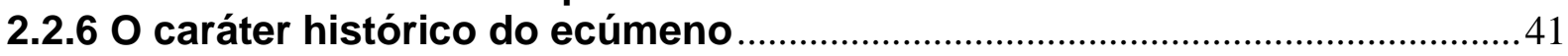

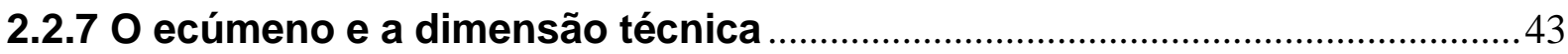

2.2.8 Ecúmeno, paisagem e Direito ………………..............................................4

2.2.8.1 Teoria tridimensional do Direito ....................................................................... 47

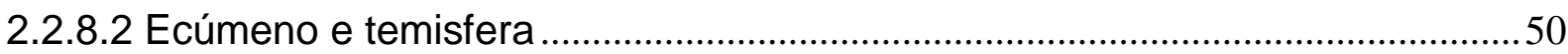

2.2.9 Paisagem enquanto dimensão jurídica ……………………………………....51

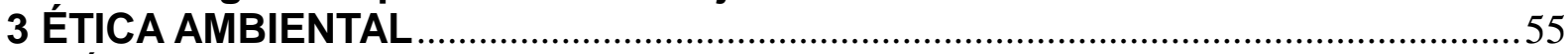

3.1 ÉTICA, LEIS NATURAIS E NATUREZA DAS COISAS ………….........................58

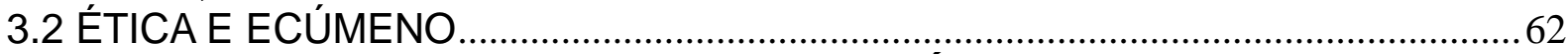

4 MEIO AMBIENTE NO BRASIL: NORMAS, POLÍTICAS E VALORES ………….......65

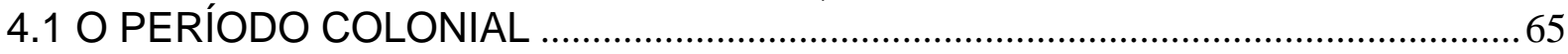

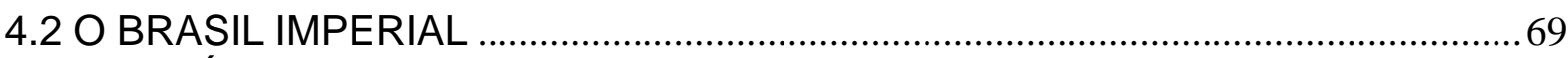

4.3 O PERÍODO REPUBLICANO: 1889-1930 ........................................................ 71

4.4 O PERÍODO REPUBLICANO A PARTIR DE 1930 E O REGIME MILITAR ...........74

4.5 O MARCO CONSTITUCIONAL DE 1988 ...........................................................

5 DIREITO AMBIENTAL: DOUTRINA, PRINCÍPIOS E CONCEITOS ……………....... 86

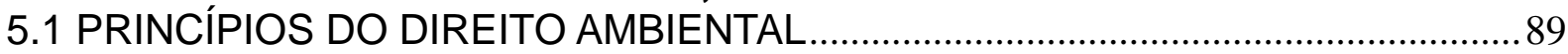

5.1.1 Princípio do meio ambiente ecologicamente equilibrado ...............................93

5.1.2 Princípio do direito à sadia qualidade de vida ..............................................93

5.1.3 Princípio do acesso equitativo dos recursos naturais....................................94

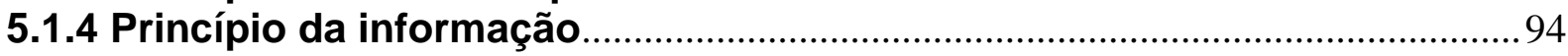

5.1.5 Princípio do desenvolvimento sustentável .....................................................95

5.1.6 Princípio do equilíbrio e princípio da capacidade de suporte .....................97

5.1.7 Princípio da prevenção e princípio da precaução .............................................98

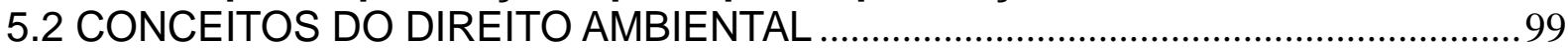

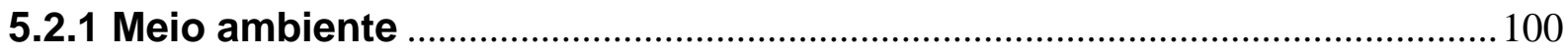

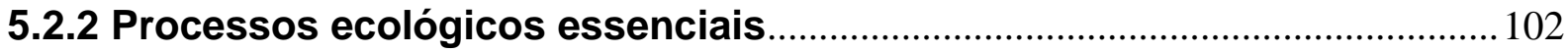

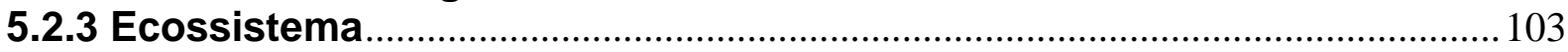

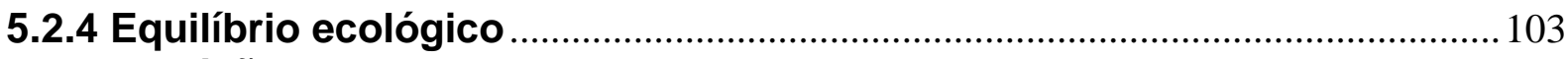

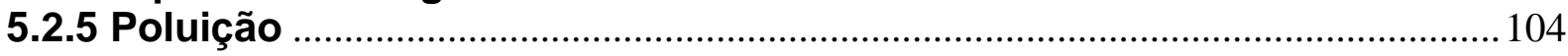

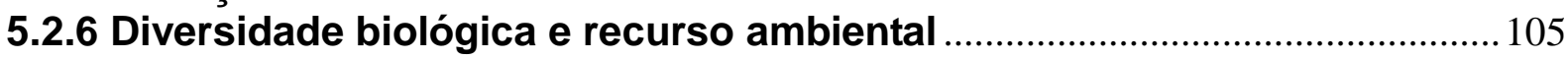

5.2.7 Espaços territoriais especialmente protegidos …………………………....... 106

5.2.8 Dano ambiental: patrimonial e extrapatrimonial ..........................................109

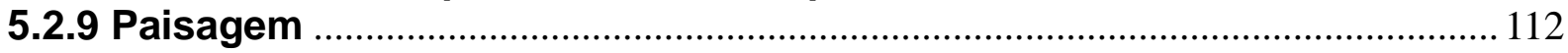

6 OS PROCESSOS JUDICIAIS ........................................................................ 115

6.1 JURISPRUDÊNCIA SOBRE PAISAGEM: OCORRÊNCIA NOS TRIBUNAIS DE JUSTIÇA ESTADUAIS 
6.2 SIGNIFICADO DA PAISAGEM NO TRIBUNAL DE JUSTIÇA DE MINAS GERAIS

6.3 DANO MORAL AMBIENTAL: USO NO TRIBUNAL DE JUSTIÇA DE MINAS GERAIS

7.1 ASPECTOS GEOGRÁFICOS GERAIS DA ÁREA.

7.2 ESCOLHA DA ÁREA PARA IMPLANTAÇÃO DO PAÇO MUNICIPAL

7.3 QUALIFICAÇÕES LEGAIS DA ÁREA

8.1 MEIO AMBIENTE ENQUANTO NATUREZA

8.2 MEIO AMBIENTE ENQUANTO TOTALIDADE NATURAL

8.3 FUNDAMENTOS DOS FATOS: NARRATIVA JURÍDICO-GEOGRÁFICA DO MUNDO 


\section{INTRODUÇÃO}

Esta tese de doutorado analisa e problematiza, geograficamente, o Direito Ambiental brasileiro. Partindo de sua própria definição, procuramos entender e discutir o conteúdo geográfico presente no Direito Ambiental e sua influência na formação da paisagem.

O Direito Ambiental é um direito humano de terceira dimensão que, no Brasil, desenvolveu-se principalmente a partir da Constituição Federal de 1988. Os direitos ambientais vêm na esteira do desenvolvimento dos direitos humanos, estes nascidos formalmente na Revolução Francesa, e somam-se aos direitos reconhecidos de liberdade e igualdade formal de todos perante a lei (direitos de primeira dimensão) e aos direitos sociais à educação, à cultura, ao trabalho e à assistência básica em saúde (direitos de segunda dimensão). Os direitos de terceira dimensão expressam a defesa dos interesses de toda a humanidade, como o direito à paz, ao desenvolvimento, ao meio ambiente ecologicamente equilibrado, independente da nacionalidade a qual se vinculam (MASSON, 2013).

Como direito de terceira dimensão, o Direito Ambiental já foi denominado, num primeiro momento, de Direito Ecológico; posteriormente, passou a ser nomeado de Direito do Meio Ambiente, Direito do Ambiente e, na atualidade, Direito Ambiental.

Sérgio Ferraz, ainda em 1972, definia o então Direito Ecológico como "o conjunto de técnicas, regras e instrumentos jurídicos organicamente estruturados para assegurar um comportamento que não atente contra a sanidade mínima do meio ambiente" (FERRAZ, 1972 apud MACHADO, 2010, p. 52) ${ }^{1}$.

Para Moreira Neto, na mesma década, em 1975, o Direito Ecológico indicava o "conjunto de técnicas, regras e instrumentos jurídicos sistematizados e informados por princípios apropriados, que tenham por fim a disciplina do comportamento relacionado ao meio ambiente" (MOREIRA NETO, 1975, p. 26).

Édis Milaré, numa definição mais recente, define o Direito do Ambiente como:

o complexo de princípios e normas coercitivas reguladoras da atividade humana que, direta ou indiretamente, possam afetar a sanidade do ambiente em sua dimensão global, visando à sua sustentabilidade para as presentes e futuras gerações" (MILARÉ, 2013, p. 255).

\footnotetext{
${ }^{1}$ FERRAZ, Sérgio. Direito Ecológico, Perspectivas e Sugestões. In: Revista da Consultoria-Geral do Rio Grande do Sul, vol.2, n.4, Porto Alegre, 1972.
} 
Nas palavras de Paulo de Bessa Antunes, o Direito Ambiental é "norma que, baseada no fato ambiental e no valor ético ambiental, estabelece os mecanismos normativos capazes de disciplinar as atividades humanas em relação ao meio ambiente" (ANTUNES, 2013, p. 6).

Paulo Affonso de Leme Machado, reconhecido doutrinador pátrio, não define exatamente o Direito Ambiental, mas traz uma coleção de definições nacionais e estrangeiras. Machado cita, por exemplo, o professor Tycho Branche Fernandes Neto, o qual conceitua o Direito Ambiental como "o conjunto de normas e princípios editados objetivando a manutenção de um perfeito equilíbrio nas relações do homem com o ambiente" (FERNANDES NETO, s/d, apud MACHADO, 2010, p. 53) ${ }^{2}$. Segundo Michel Prieur, também citado por Machado, o Direito Ambiental é:

constituído por um conjunto de regras jurídicas relativas à proteção da natureza e à luta contra as poluições (...) é um Direito portador de uma mensagem, um Direito do futuro e da antecipação, graças ao qual o homem e a natureza encontrarão um relacionamento harmonioso e equilibrado" (PRIEUR, 2011 apud MACHADO, 2010, p. 53) ${ }^{3}$.

Das definições acima colecionadas, fica evidente a relevância do Direito Ambiental para a análise geográfica, uma vez que a regulamentação da relação do homem com o meio ambiente é um dos temas mais clássicos e caros ao conhecimento geográfico.

A ideia de trabalhar com o Direito Ambiental brasileiro sob uma perspectiva geográfica surgiu ainda durante o desenvolvimento das pesquisas de mestrado, quando analisamos a relação entre a formação da paisagem urbana de Poços de Caldas (MG) e as leis municipais de proteção ao meio ambiente e ao patrimônio cultural. Naquele momento, as pesquisas mostraram a força das leis na definição das formas e na qualificação das paisagens urbanas da cidade mineira: normas de uso e ocupação do solo; diversos índices urbanísticos (tamanho de vias de circulação, taxas de ocupação e coeficientes de aproveitamento de lotes, afastamentos e recuos de obras, etc.); definições e delimitações de áreas de interesse patrimonial e ambiental estabeleciam padrões gerais na morfologia urbana ao mesmo tempo em que imprimiam valores à paisagem da cidade (SOUZA, 2012).

2 FERNANDES NETO, Tycho Brahe. Direito Ambiental - Uma Necessidade. Imprensa da Universidade Federal de Santa Catarina, s/d.

${ }^{3}$ PRIEUR, Michel. Droit de VEnvironnement. 6 ed. Paris, Dalloz, 2011. 
Ao longo do trabalho, o contato com a ciência do Direito - e, de forma mais próxima, com o Direito Ambiental - despertou inquietações acerca de uma certa substância geográfica presente nos diplomas legislativos e, especialmente, nas teorias e doutrinas jurídicas. Quer dizer, para além dos artigos e incisos enumerados na lei, um conteúdo a respeito de espaços, paisagens, territórios, ou seja, uma verdadeira ideologia geográfica (MORAES, 2005), era evidente no discurso doutrinário dos juristas.

Concomitantemente, o levantamento e pesquisa bibliográfica sobre a relação entre Geografia e Direito revelou uma escassez de obras específicas sobre o assunto - principalmente no âmbito nacional - mas um crescente interesse de pesquisadores pelo tema, com a emergência de artigos e obras sobre tal relação. Destacaram-se deste levantamento bibliográfico os trabalhos de Jean Marie Perret (1994), Nicholas Blomley (1990; 2001; 2003; 2008), David Delaney (2001; 2003; 2009), J. Holder e Carolyn Harrison (2003), Ruthenford Platt (1976; 2004), Patric Forest (2009), Romain Garcier (2009). No Brasil, dentre os trabalhos emergentes estão Afrânio Nardy (2003); Ricardo Mendes Anta Júnior (2005), Alcindo José da Sá (2009, 2011), Jaiza Maria Pinto Fraxe (2012), e Luiz Ugeda (2107). Deve-se mencionar ainda as contribuições de Milton Santos (2004; 2004a; 2014), Maria Laura Silveira (1997) e José Nicolau dos Santos (1954; 1956).

Da pesquisa empírica sobre Poços de Caldas somada aos estudos teóricos a respeito da relação entre Geografia e Direito, ficou claro o caráter intrinsecamente espacial da lei (o que Blomley, Delaney e Ford (2001) tentam traduzir com o termo splice) e a manipulação discursiva da realidade geográfica para alcançar os propósitos legais e políticos almejados (SOUZA, 2012).

No correr das pesquisas entre os diversos campos do Direito (Filosofia Jurídica, História do Direito, Direito Constitucional, Direito Civil, etc.), o Direito Ambiental mostrou-se de especial interesse, primeiro pela urgência da questão nos dias atuais e, também, pela própria relação que as normas ambientais objetivam regulamentar, tema tradicional de discussões geográficas: a relação do homem com o meio ambiente.

De fato, na Geografia, desde a sua institucionalização, percebe-se que a relação do homem com o meio foi a base para o entendimento das diversidades presentes na superfície terrestre. Ratzel, por exemplo, via na ligação das sociedades com o solo as razões e fundamentos do nascimento, desenvolvimento e morte dos 
Estados. Vidal de La Blache, por sua vez, enxergou na relação desenvolvida ao longo do tempo entre o homem e a natureza os fundamentos para a formação das paisagens e regiões. A diversidade de combinações dos fenômenos naturais e humanos também foi a base para Hartshorne explicar as semelhanças e diferenças entre áreas da Terra.

Mesmo antes de o conhecimento geográfico ser sistematizado, porém, filósofos e cientistas políticos já investigavam a influência do meio - especialmente a influência do clima sobre os povos - a exemplo dos trabalhos de Hipócrates e Montesquieu.

O Direito Ambiental, entretanto, sendo um ramo relativamente recente do Direito, não acumula discussões aprofundadas de tal relação. Com efeito, salvo considerações encontradas em capítulos referentes à ética ambiental, pouco se observa na doutrina de Direito Ambiental, pelo menos no que concerne à doutrina brasileira, ponderações ou problematizações sobre a relação do homem com o meio ambiente e sobre a forma como ela é regulamentada.

Não obstante, o Direito Ambiental, por meio dos princípios, normas ambientais e instrumentos jurídicos, forja uma verdadeira narrativa geográfica da relação do homem com o meio, participando ativamente, pela força coercitiva do Direito, na produção e formação dos espaços, paisagens e territórios.

Com efeito, quando disciplina o comportamento humano face ao meio ambiente com vistas à manutenção da qualidade de vida, do equilíbrio ecológico e da sustentabilidade, as leis ambientais atuam na produção material e subjetiva da paisagem.

Foi a partir destas premissas e dando continuidade aos estudos iniciados no mestrado, que se desenhou a problemática da presente pesquisa. Cabe acrescentar, contudo, algumas questões abertas pelos estudos sobre Poços de Caldas não totalmente esclarecidas. Nos trabalhos realizados durante o mestrado ficava clara a força das normas patrimoniais na dinâmica paisagística do centro urbano da cidade, enquanto as leis ambientais tinham força e recaiam mais nas áreas periféricas do município.

Restou dúvidas, entretanto, quanto ao aspecto não normativo do Direito, ou seja, a influência do Direito tomada para além das leis escritas. Se os diplomas legais tiveram incontestável importância na configuração da paisagem urbana de Poços de Caldas, regulamentando as intervenções no meio ambiente patrimonial e 
natural, faltaram discussões mais aprofundadas em nível teórico e prático dos princípios e conceitos do Direito, em geral, e do Direito Ambiental, em específico. A problemática da pesquisa estava, então, definida.

Dessa forma, com base na revisão bibliográfica e nos estudos preliminares de Direito Ambiental, desenhou-se a hipótese de que ao regulamentar a relação do homem com o meio ambiente, o Direito Ambiental naturaliza o meio ambiente, tomando-o precipuamente na sua dimensão natural e ecológica. Repete-se, neste sub-ramo do Direito, o paradigma dicotômico da relação entre natureza e sociedade que marca a visão da ciência moderna.

De fato, foi observado durante os estudos sobre Poços de Caldas que os princípios e conceitos do Direito Ambiental (equilíbrio ecológico, biodiversidade, florestas, etc.) tendem a uma naturalização do meio ambiente em detrimento dos fatores sociais em sua constituição e percepção.

Teoricamente, a análise e problematização geográfica do Direito Ambiental proposta neste trabalho são desenvolvidas tendo como suporte as teorias de ecúmeno, mediance e paisagem elaboradas por Augustin Berque e, na seara do Direito, a teoria tridimensional do Direito desenvolvida por Miguel Reale.

Em síntese, entende-se que a paisagem é parte integral e inseparável da vida do homem, seja individual ou socialmente. No avançar do tempo, às vezes em ritmo mais longo, em outras vezes mais curto, os movimentos da sociedade são acompanhados de perto por transformações na paisagem: novas formas ou novos usos das formas antigas; novas técnicas que se descobrem; novos valores ou relações sociais que se estabelecem na sociedade participam todos de uma nova configuração da paisagem.

A paisagem consubstancia, durante a vida humana, todas as transformações operadas sobre a superfície terrestre, as técnicas utilizadas, os valores e a cultura que as orientam. É o que Berque denomina 'paisagem marca'. Por outro lado e ao mesmo tempo, a paisagem é uma constante presença a fundamentar as ações do homem, impondo certos condicionantes no seu evolver histórico. Berque denomina de 'paisagem matriz'.

Nesse sentido, as mudanças operantes, a transformação da paisagem é a própria transformação do homem, da sociedade. Assim, e citando Éric Dardel, a paisagem é a "inserção do homem no mundo, lugar de combate pela vida" e "expressão fiel de sua existência" (DARDEL, 2011, p. 31). 
Roberto Lobato Corrêa, nesse mesmo sentido, afirma ser a paisagem uma materialidade social, "meio no qual a vida humana flui rotineiramente". A paisagem, portanto, ao mesmo tempo em que reflete o social em suas necessidades, possibilidades e conflitos sociais, é também permanência, "condição de reprodução social, sutil que seja, anunciando o futuro imediato" (CORREA, 2015, p. 10).

O meio ambiente onde o homem vive e habita, então, é a própria paisagem forjada no seio da sociedade e não meramente uma natureza primeira hermeticamente separada do homem.

Poços de Caldas mostra bem esta vinculação entre sociedade e paisagem na medida em que o espaço urbano da cidade assumiu formas e valores que refletiam os anseios civilizatórios da elite social brasileira no alvorecer do século XX. A paisagem poços-caldense assumia, nesse momento, o movimento social de modernização da nação, traduzido no traçado urbano, nos aspectos arquitetônicos das fachadas e na higiene dos espaços (MARRAS, 2004; SOUZA, 2012).

A paisagem de Poços de Caldas bem faz lembrar as palavras de Maurice Ronai (2015, p. 6) quando diz:

é através da paisagem que o território se torna visível aos cidadãos, o território como rede de belas paisagens que dão crédito à bondade da nação, conforme a ideia platônica do acordo entre a perfeição da forma (paisagem) e a excelência da coisa (nação).

Já no início do século XXI, a paisagem de Poços de Caldas começa a incorporar os interesses de preservação do meio ambiente, figurando na morfologia urbana áreas verdes e espaços ambientalmente qualificados, como reservas legais e áreas de proteção ambiental (SOUZA, 2012).

Em escala nacional, nessa ordem de ideias, Corrêa (2015) preconiza três tipos ideais da paisagem urbana brasileira, cada um representando uma parcela da sociedade nacional. A primeira, a fachada litorânea com altos prédios residenciais; a segunda, a favela consolidada com elevada densidade de edificações separadas por ruas, ruelas e becos; a terceira, as áreas de amenidades criadas, que recebem significativo investimento de capital (CORRÊA, 2015). O autor assim descreve: "Orla litorânea com belos edifícios, tristes e feias favelas inconclusas e frias e autossegregados setores de amenidades, eis três importantes tipos ideais de paisagem urbana brasileira" (CORRÊA, 2015, p. 10). 
$\mathrm{Na}$ medida em que se tem a paisagem e sociedade, então umbilicalmente ligadas, há de se considerar também que a paisagem incorpora as incontáveis leis, valores jurídicos e princípios normativos que ordenam as relações sociais. Ou seja, a paisagem contém a dimensão normativa da sociedade.

A disciplina do Direito efetivamente faz parte da paisagem. Mas o Direito é entendido aqui, porém, não somente como a lei em si, a norma escrita, mas também como o conjunto indissociável de fatos, valores e normas, conforme a abordagem da teoria tridimensional do Direito (REALE, 2000). O sistema jurídico é composto por fatos (fatos econômicos, fatos políticos, fatos geográficos) juridicamente qualificados integrados por uma norma (REALE, 2000; 2002). No nosso caso particular, as disciplinas do Direito Ambiental brasileiro equaciona fatos ambientais que são ambiental/juridicamente valorados, ambos compostos na norma ambiental.

Desse modo, ao regulamentar o comportamento humano, instituindo permissões e proibições à atividade social frente ao meio ambiente, o Direito Ambiental se agrega à paisagem como marca, por um lado, e como matriz, por outro. Inicialmente como marca, exposto nos contornos dos conjuntos paisagísticos e, posteriormente, como matriz, pela força normativa que a paisagem revela.

Ao transformar a superfície terrestre formando paisagens condizentes com a estrutura (jurídica) social, o homem é constrangido a agir, perceber e se apropriar do meio ambiente segundo as leis ambientais, assumindo a paisagem, pois, expressão material e axiológica presente no Direito Ambiental.

Mas é preciso entender melhor geograficamente esta participação do Direito na formação das paisagens, quer dizer, investigar em que dimensão exata configurase o meio ambiente e em que sentido as normas ambientais têm direcionado o comportamento humano e a formação da paisagem.

Este trabalho caminha nesta direção, tentando contribuir também, por outro lado, para as discussões em torno da relação entre a Geografia e o Direito.

Metodologicamente, o trabalho é desenvolvido com base numa pesquisa indutiva exploratória do conjunto da doutrina brasileira de Direito Ambiental e da jurisprudência do Tribunal de Justiça de Minas Gerais. O objetivo é analisar o entendimento jurídico sobre o meio ambiente através das definições e interpretações dos juristas pátrios.

Os doutrinadores foram selecionados com base em pesquisa nas ementas da disciplina de Direito Ambiental do curso de Direito de universidades da região sul e 
sudeste do Brasil, onde se localizam importantes Faculdades de Direito do país 4 . Foram sistematizados e caracterizados os princípios e conceitos "ambientais" conforme as definições predominantes nos diferentes autores selecionados, trazendo também, para a caracterização, obras e autores objetos das pesquisas preliminares que pudessem contribuir para a descrição almejada.

$\mathrm{Na}$ pesquisa da jurisprudência, o Tribunal de Justiça de Minas Gerais foi escolhido devido às possibilidades de diálogo com trabalhos de pesquisa anteriormente desenvolvidos sobre o município de Poços de Caldas. A pesquisa no tribunal mineiro concentrou-se nos termos paisagem e dano moral ambiental, termos cujo uso como palavras-chave de busca justificou-se, considerando o maior peso à dimensão humana que portam. Ou seja, outros conceitos (ecossistema, equilíbrio ecológico, etc) mostraram-se, já nas pesquisas preliminares na doutrina, definições essencialmente ecológicas, biológicas, enquanto paisagem e dano moral ambiental abria espaço dentro do Direito Ambiental para considerações mais amplas sobre a participação do homem.

O processo judicial a respeito da construção do Paço de Poços de Caldas também foi analisado para complementar a análise doutrinária e jurisprudencial anteriormente realizada, no sentido de discutir a participação do Direito na configuração da paisagem. Por outro lado, as celeumas criadas em torno da localização do Paço contribuem para entendimento mais apurado do comando do Direito na dinâmica urbana da cidade.

Estruturalmente, a tese está organizada da seguinte forma: no capítulo primeiro discute-se a relação do homem com o meio ambiente, a fim de trazer subsídios para problematização do Direito Ambiental. Foi esboçado um breve resumo histórico dos pensadores e estudiosos que se preocuparam com tal relação. Em seguida, a relação do homem com o meio ambiente é discutida na perspectiva da teoria do ecúmeno de Augustin Berque: recupera-se, de início, a crítica ao paradigma da ciência moderna que separa homem e natureza e o entendimento ontológico da relação proposto por Berque; posteriormente, destacam-se as

Outros centros relevantes de Direito podem ser lembrados, fora das regiões sul e sudeste, como a Faculdade de Direito da Universidade Federal de Pernambuco (antiga Faculdade de Direito de Recife) e a Faculdade de Direito da Universidade Federal da Paraíba. Porém, obtivemos pouco retorno das informações solicitadas das coordenações do curso de Direito fora da região sul e sudeste. 
dimensões de totalidade/particularidade, técnica, histórica e jurídica do ecúmeno, finalizando com considerações da paisagem enquanto dimensão jurídica.

O capítulo segundo discute brevemente a ética ambiental. O texto está estruturado basicamente na oposição e intercâmbio entre leis da natureza e leis sociais: a corrente ecocêntrica do ambientalismo é confrontada com autores que criticam a associação das leis naturais com as leis humanas, terminando o capítulo com as formulações éticas da teoria do ecúmeno.

O capítulo terceiro aborda as políticas, valores e normas que orientaram ou orientam a proteção ao meio ambiente no Brasil desde o período colonial. Através de pesquisa bibliográfica desenhou-se a visão e valores que conduziram a política nacional de proteção ambiental e as leis mais representativas de cada período (colônia, império e as diferentes fases do período republicano). Buscou-se destacar as continuidades e rupturas na apreciação do meio ambiente no Brasil, por um lado pela permanência conjunta de uma visão econômica e louvatório em relação à natureza e, por outro, pela introdução de valores propriamente ambientais no contexto brasileiro.

Os capítulos quarto e quinto dedicam-se à descrição dos princípios, conceitos e dos processos judiciais. Optou-se por um encadeamento mais descritivo destes elementos, deixando a análise e problematização para capítulos posteriores. $\mathrm{O}$ capítulo sexto é voltado para a descrição do processo que envolveu a construção do Paço Municipal, sendo feita inicialmente uma caracterização geográfica da área onde seria instalado o empreendimento.

Feitas as descrições e caracterizações no universo doutrinário e jurisprudencial, os resultados são então analisados sob a ótica do ecúmeno, mediance e paisagem no capítulo sétimo. Tendo por horizonte a hipótese levantada, argumentou-se a respeito da naturalização do meio ambiente dentro do Direito Ambiental e a consequente restrição do significado semântico do termo. Ao mesmo tempo, argumenta-se pela totalidade e unidade do meio ambiente jurídico, conseguida pela sua identificação com os fenômenos propriamente naturais. Ainda no capítulo sétimo, discutiu-se a construção da realidade geográfica operada principalmente pela descrição dos fatos jurídico/ambientais sob uma perspectiva ecológica. Por fim, avalia-se a composição da mediance e da paisagem derivadas da aplicação do Direito Ambiental. 


\section{RELAÇÃO DO HOMEM COM O MEIO AMBIENTE}

\subsection{INTRODUÇÃO: BREVE PERSPECTIVA HISTÓRICA}

O Direito Ambiental procura regulamentar, por meio dos princípios, normas e instrumentos jurídicos, a relação do homem com o meio ambiente. O Direito Ambiental, contudo, não foi o primeiro e não é o único a se preocupar com tal relação.

De fato, a relação do homem com o meio onde vive, habita e produz interessou pensadores em diferentes épocas e foi interpretada sob diferentes perspectivas. Curiosidades sobre como são os lugares e povos distantes; como eles se organizam nesses espaços e como encontram soluções de sobrevivência e produção face a um meio diverso; por que os comportamentos humanos e a cultura são diferentes nos diferentes espaços que habitam são questões que frequentemente inquietaram os estudiosos.

Nos estudos sobre tal relação, ora voltava-se a atenção para a força do meio sobre as culturas, ora para a ação humana sobre o meio, mas as preocupações em torno da ligação do homem com o ambiente atravessou as épocas.

A ideia das influências ambientais sobre a cultura é tão importante historicamente pelos seus questionamentos como pelo seu próprio contexto intelectual e filosófico. É parte daquele antigo e amplo contraste entre physis e nomos, entre natureza e lei ou costume. É uma ideia profundamente envolvida na interpretação da infinitamente fascinante ordem das diferenças humanas (GLACKEN, 1976 apud SEEMANN, 2012, p. 4) ${ }^{5}$.

$\mathrm{Na}$ antiguidade clássica tem lugar a ideia, que perdurará durante séculos, de superioridade do homem perante a natureza. Tudo que se encontra na natureza existe para o benefício do homem (PONTING, 1995). Aristóteles afirmava que "se a natureza não faz nada incompleto e nada em vão, devemos acreditar que ela fez todos os animais para o bem-estar dos seres humanos" (ARISTÓTELES apud PONTING, 1995, p. 239) ${ }^{6}$. Segundo o professor Clive Ponting:

o pensamento clássico geralmente estava caracterizado pela ideia dos seres humanos como organizadores da natureza. Os seres humanos eram

\footnotetext{
${ }^{5}$ GLACKEN, Clarence J. Traces on the Rhodian shore. Nature and culture in Western thought from ancient times to the end of the eighteenth century. Berkeley/Los Angeles: University of California Press, 1976.

${ }^{6}$ ARISTÓTELES. A Política, s.d.
} 
colocados em um plano mais elevado que o dos outros animais: sua capacidade de criar seu próprio mundo implicava uma posição superior, de finalizador da criação crua (PONTING, 1995, p. 239).

A ascensão do cristianismo durante o império romano acrescenta às ideias do período a visão judaica dos textos sagrados, os quais reforçam a hierarquia superior do homem no mundo natural. De fato, lê-se no livro sagrado da Gênesis: "crescei e multiplicai e povoai a Terra e dominai-a; e dominai os peixes do mar e as aves dos ares e todos os seres vivos que se movem sobre a Terra" (BÍBLIA SAGRADA apud PONTING, 1995, p. 240) ${ }^{7}$.

Ainda durante a antiguidade clássica, e em paralelo a este discurso antropocêntrico, uma segunda linha de pensamento desenvolve-se com Hipócrates, filósofo que analisa as relações do homem com o meio em que vive.

Para Hipócrates, existe uma ligação que coordena as condições do ambiente e o estado que o homem se apresenta. Certo determinismo por analogia, como define Paul Claval (2014), vincula o homem ao meio; tudo que acontece no microcosmo humano não é senão reflexo, uma concordância com o macrocosmo que o circunda. Assim:

[o determinismo hipocrático] baseia-se em uma comunicação íntima entre o corpo do homem e o Mundo (...). O determinismo não se concebe na causalidade, mas na analogia. Trata-se certamente da analogia macrocosmo/microcosmo, que tem um lugar importante no pensamento grego. O corpo do homem não se sobrepõe ao mundo: o homem possui, para além do seu corpo físico, um corpo cósmico (STASZAK apud CLAVAL, 2014, p. 115).

Durante a idade média, com o forte predomínio da igreja sobre a sociedade, pouco se mudou quanto à crença da superioridade humana sobre a natureza, herdada do período clássico, servindo esta de moldura a novas formulações. São Tomás de Aquino, por exemplo, segundo Ponting (1995) justificou a posição privilegiada dos seres humanos pela hierarquia que ocupava entre os seres vivos, conforme o plano divino:

Ele [São Tomás de Aquino] argumentou que existia uma hierarquia dos seres, do mais insignificante até Deus, mas, apesar de existir uma razão para a existência de cada um deles, o plano geral era somente do conhecimento de Deus. Os seres humanos ocuparam seu lugar privilegiado acima dos animais e seu domínio sobre a natureza fazia parte do plano divino - as criaturas racionais deveriam governar as irracionais (os animais) e isto estava bem ilustrado pela capacidade demonstrada pelos seres humanos de domesticar os animais (PONTING, 1995, p. 242).

\footnotetext{
${ }^{7}$ BÍBLIA SAGRADA. s.d.
} 
No Renascimento, uma atenção especial foi dada para os usos e costumes dos povos. Consoante Paul Claval, neste momento a etnografia ganhava destaque e então "falava-se mais frequentemente dos usos e costumes das populações do que do meio no qual vivem e exploram" (CLAVAL, 2014, p. 117). Foram sublinhadas, dessa forma, informações sobre os hábitos alimentares, as vestimentas, os instrumentos de trabalho e a arquitetura das moradias.

Posteriormente, quando da ascensão dos Estados-nação, o poder secular se sobrepôs ao poder da lgreja e o conhecimento de novos povos e lugares proporcionado pelas grandes navegações, o que fez com que as ideias hipocráticas fossem retrabalhadas em função das novas necessidades da época.

Teóricos sob diferentes pontos de vista, como Montesquieu, John Locke e Jean Bodin, construíram teorias que buscavam dar legitimidade às novas instituições ao mesmo tempo em que tentam relacioná-las ao ambiente físico onde surgem (BONAVIDES, 2013). Procura-se formular interpretações de como se deve governar em face da alteridade física e social reinante.

Jean Bodin, por exemplo, teórico do século XVI, analisa as maneiras de governar em meios naturais e sociais diferentes. Para Claval (2014), Bodin pensa a maneira de governar segundo os costumes dos povos. Diz Claval:

Os seis livros da república fazem da soberania o atributo comum dos
Estados, mas a forma de se governar deve ser adaptada à maneira de ser e
de viver dos sujeitos. Bodin insiste no papel da latitude e divide a distância
do polo ao equador em três faixas de $30^{\circ}$ cada uma, depois subdivide cada
uma em duas: a cada domínio correspondem povos de humores diferentes.
É normal que a sua cor de pele, os seus costumes e a sua organização
social se alterem (CLAVAL, 2014, p. 117).

Por outro lado, Montesquieu, filósofo e político francês do século XVIII, no seu livro "O Espírito das Leis" tenta explicar as leis de um povo segundo a influência do meio onde vive, com especial ênfase à influência do clima (MARIAS, 2004). Mas não há uma predominância do clima sobre a sociedade na obra de Montesquieu, de acordo com Romain Garcier (2009), pois o filósofo coloca as leis e o quadro natural num mesmo plano, inexistindo uma sobredeterminação de um sobre o outro.

Também John Locke, filósofo inglês e ideólogo do liberalismo, apoiava-se na ideia geral de que a influência do meio é determinada pelas sensações que emergem no contato com o mundo. "É através da ação das sensações que se imprimem na memória que as aptidões se desenvolvem" (CLAVAL, 2014, p. 121). A partir daí, constrói-se a ideia de controle do ambiente onde o homem vive a fim de 
atingir determinados fins. Novamente, a superioridade do homem sobre a natureza era reafirmada.

Paul Claval conclui, enfim, dizendo: "a ideia de ambiente impõe-se, por conseguinte, no domínio político, onde permanece lugar-comum de Jean Bodin a Montesquieu e para além dela" (CLAVAL, 2014, p.118).

Aqui ainda encontramos a ideia do primado do homem sobre o mundo natural, quando, por exemplo, Francis Bacon, filósofo do renascentismo, diz ser o mundo feito para o homem e não o homem para o mundo: "o homem, se examinarmos as causas finais, pode ser encarado como o centro do mundo, tanto que, se o homem fosse tirado do mundo, o resto pareceria vazio, despido de meta ou significado" (BACON apud PONTING, 1995, p. 246).

Durante muito tempo, tanto o pensamento clássico, com suas diferentes formulações, quanto as ideias hipocráticas continuam a influenciar as interpretações sobre a relação do homem com o mundo natural.

Ainda no século XIX, as ideias hipocráticas seduziram as reflexões de Vidal de La Blache (CLAVAL, 2014). Com efeito, Vidal fazia corresponder às características do relevo, do clima ou da vegetação a história de vida dos povos e, particularmente, sobre como condicionavam a conformação das regiões. "Tal área [contrée], tais homens", lembrava o mestre da geografia francesa, embora já exprimisse também uma explicação causal de cunho darwinista, para além da analogia hipocrática. Pondera Ribeiro (2012),

\footnotetext{
Que o homem não escapa nada à influência do meio [milieu] local, bem em sua constituição física e moral; que as obras que se originam de suas mãos contraem uma marca particular em conformidade com o solo, o clima e os seres vivos que o cercam: nada de mais generalizado e mais antigo a ser admitido. Tal área [contrée] tais homens, diz-se (LA BLACHE, 1903 apud RIBEIRO, 2012, p. 118).
}

Mas La Blache entende que não se pode pensar uma relação direta e sem mediações entre o homem e o meio, porquanto um conjunto de técnicas, costumes e história colocam-se entre a relação estabelecida. É preciso antes atentar para os gêneros de vida de cada sociedade (CLAVAL, 2014).

Além das ideias hipocráticas, outra corrente de pensamento - o ambientalismo darwinista - emerge no século XIX como novo paradigma para interpretação da relação do homem com o meio e coloca a questão do comportamento dos homens como resultado da seleção natural a qual estão submetidos: a relação do homem 
com o meio opera uma seleção onde certos comportamentos e culturas sobrevivem em detrimento de outros (CLAVAL, 2014).

Friedrich Ratzel, nesse sentido, ainda no século XIX e antes mesmo de La Blache, influenciado pelo ambientalismo darwinista, entende que o crescimento ou decadência dos Estados é favorecido ou impedido pelo solo onde se desenvolve: "o Estado constitui-se como organismo ligado a uma fração determinada da superfície da terra, de modo que as suas propriedades se originam das do povo e do solo", afirma o geógrafo alemão (RATZEL, 2011, p. 52).

Ratzel intenta explicar a evolução da sociedade e dos Estados pelo seu aspecto espacial, consoante o uso e mobilidade nos diferentes meios (SEEMANN, 2012). Nas palavras de Don Mitchell:

O Estado era essencialmente uma coisa viva, que, como outras coisas orgânicas, precisava crescer para viver (...) O Estado era, então, em grande medida, uma ligação natural entre pessoas e o ambiente, a expressão espacial do (...) espiritual, mas também dos laços orgânicos entre pessoas e lugares (...) Ratzel argumentava que a ligação entre o ambiente e as pessoas não era uma [ligação] de um simples determinismo (...), mas apesar de tudo, ele deixou claro que o desenvolvimento social ou cultural do Estado (...) era diretamente relacionado à habilidade do Estado de crescer (MITCHELL, 2000 citado por SEEMANN, 2012, p. 7) $)^{8}$.

Com efeito, Ratzel afirmava:

O desenvolvimento do Estado é a organização progressiva do solo através de uma relação mais estreita com ele. Com o crescimento demográfico, as relações do povo com o seu solo reforçam-se, os recursos naturais sempre são mais bem explorados, o povo cresce em potência até impermeabilizar as fronteiras (...) vasto, mais as suas relações com o povo são tênues. $A$ diferença entre o Estado de um povo civilizado e o de um povo bárbaro se relaciona ao fato de que a organização do solo é muito mais desenvolvida no primeiro do que no segundo. (RATZEL, 2011, p. 52).

As ideias darwinistas geraram ainda, como consequência, o enriquecimento de uma nova disciplina que se forjava, a ecologia, a qual teve grande impacto nas formas como se analisa o meio. De fato, a ecologia introduz a matemática e a física nos estudos sobre as interações entre a biocenose e o biótopo a ela correspondente, fazendo destacar o componente físico-químico das relações entre os animais, plantas e o meio físico e integrando-os no conceito de ecossistema (ACOT, 1990).

A ecologia desdobrou-se ainda como ecologia humana, voltada de início para as bases ecológicas dos processos de aculturação social ao mesmo tempo em que

\footnotetext{
${ }^{8}$ MITCHELL, Don. Cultural geography. A critical introduction. London: Blackwell, 2000.
} 
conceitos ecológicos eram aproximados dos estudos de sociologia urbana (ACOT, 1990).

Por fim, como bem lembra Clive Ponting, atualmente não é possível analisar a relação do homem com a natureza se não se fizer referência ao pensamento econômico enquanto disciplina científica, porquanto as premissas e o sistema econômico de uma sociedade e os valores que ela engloba "são essenciais para compreensão da visão moderna do relacionamento entre os seres humanos e o mundo natural" (PONTING, 1995, p. 255).

Segundo Ponting, as diferentes correntes econômicas - da economia clássica, marxista até a keynesiana e ultraliberal - tratam os elementos da natureza como bens de capital, "um conjunto de ativos que devem ser transformados em fonte de lucro" (PONTING, 1995, p. 258). Presumem a infinitude das fontes de materiais e energia e concentram demasiada atenção, então, na organização da produção.

Desse modo, a natureza continuou sendo vista como utilidade, bens que servem exclusivamente para as finalidades humanas. A relação do homem com o meio onde vive é norteada em grande medida, então, pelos ditames da economia, da produção de riquezas a partir da exploração da natureza.

\subsection{ECÚMENO}

No âmbito geográfico, dentre as formulações teóricas mais atuais sobre a relação do homem com o meio, as ideias do geógrafo e filósofo francês Augustin Berque destacam-se por equacionar a questão a partir do conceito de ecúmeno, mediance e paisagem. De forma sintética, a teoria de Berque entende que tal relação desenvolve-se de forma orgânica a integrar o meio ecológico, os sistemas técnicos e a esfera simbólica da humanidade.

A noção ou ideia de ecúmeno existe desde a antiguidade clássica e significava a parte da terra habitada pela espécie humana. Pensadores do período clássico, em sua maioria, consideravam que o ecúmeno correspondia à zona temperada do hemisfério setentrional, situado entre o círculo polar ártico, ao norte, e o trópico de câncer, ao sul. Para além destes limites havia apenas desertos inabitados, frequentados por criaturas não humanas (AKAL, 1991).

O mundo habitado, porém, era visto de um ponto de vista particular e, no período clássico, o mundo grego era a referência: confrontava-se os modos de viver, 
as instituições e cidades gregas com aquelas existentes no mundo não grego, dos "exóticos" e bárbaros (TISSIER, 2004; BERQUE, 2010).

O ecúmeno era ainda dividido de diversas maneiras: entre gregos e bárbaros, divisão em três continentes (Europa, Ásia e África) ou por divisões geométricas (AKAL, 1991).

Com o descobrimento de novas terras e novos povos, outras partes habitadas do mundo são reveladas, estendendo os contornos do ecúmeno para além das zonas temperadas e forçando sua redefinição.

Na Geografia, no momento de definição de um campo particular de análise e reflexão, Vidal de la Blache recupera o termo, considerando determinada superfície da terra habitada pelo homem, o ecúmeno, a primeira questão que se coloca à geografia humana (AKAL, 1991; TISSIER, 2004).

Em seguida, Max Sorre desenvolve a perspectiva do ecúmeno, integrando-o na sua análise da ecologia do homem. Sorre examina os limites polares dos povoamentos, as altitudes que alcançam, além de suas descontinuidades espaciais em contraste com a ubiquidade humana, tentando entender a "formação do espaço habitado, o œkoumeno" (SORRE, 1948).

"O homem pode viver por todo lugar" sentencia Sorre logo a princípio: "a superfície inteira da Terra é seu domínio e ainda as camadas inferiores da atmosfera e as águas superficiais e mesmo as camadas superiores da crosta" (SORRE, 1948, p. 78), alcançando os povoamentos humanos altitudes de 7.000 a 7.500 metros e estendendo-se por regiões polares além do paralelo $70^{\circ}$ norte e sul.

A ocupação humana do espaço, porém, é uma ocupação ecológica, no sentido de que a própria morfologia e fisiologia humana são afetadas pelas condições ambientais. A constituição das raças, a cor da pele, o metabolismo corporal e tantas outras funções biológicas do corpo reagem às forças do meio.

(...) não há grupos humanos capazes de se fixar e de se perpetuar não
importa onde, conservando a totalidade de suas características fisiológicas
e anatômicas. Cada grupo confinado em um habitat bem caracterizado
corresponde a um tipo específico, qualquer coisa como uma raça
geográfica" (SORRE, 1948, p. 109).

Augustin Berque, por sua vez, elabora uma proposta para o ecúmeno a partir de uma abordagem ontológica. Segundo Berque, as sociedades conformam-se na confluência das forças do espaço que ocupam, incluídos aí os fatores sociais, técnicos e ecológicos. Assim, pode-se dizer que não há uma sociedade, 
abstratamente considerada, cuja existência se dá sobre uma porção da superfície terrestre a sofrer passivamente transformações advindas da atividade humana ou, ao contrário, uma natureza existente antes ou acima do homem a determinar seus comportamentos básicos. Nesse sentido, a teoria de Berque recupera e reforça discussões já realizadas por geógrafos sobre a falácia de se separar a natureza do seu componente humano.

Tal perspectiva berquiana é elaborada a partir da crítica da dicotomia que predomina na ciência moderna, cujo paradigma funda-se na separação entre homem e natureza. Ao contrário deste paradigma da ciência ocidental moderna, o ecúmeno parte do princípio da inseparabilidade entre os homens e o meio onde vivem e habitam.

\subsubsection{Ecúmeno e crítica à dicotomia homem-natureza}

Separar a existência da natureza da existência humana é a visão científica predominante desde pelo menos as teorias de Newton, Galileu, Decartes e Francis Bacon, podendo-se encontrar tal ideia, porém, ainda no período clássico da história.

Com efeito, já em Sócrates tem início o rompimento da ligação mágica entre o homem e a natureza, tornando o homem, se não separado do mundo, um ser existente por si. Robert Lenoble, estudando a história da ideia de natureza desde a antiguidade clássica, afirma que em Sócrates o homem torna-se o "primeiro sistema fechado que se conseguiu constituir e, por conseguinte, o primeiro 'fato'” (LENOBLE, 2002, p. 59). A partir daí, diz o autor, "a natureza recebe por seu turno o direito de se organizar e começa a receber uma objetividade verdadeira", (LENOBLE, 2002, p. $60)$.

Mesmo em Hipócrates, o meio já é algo exterior ao homem, é o macrocosmo que não se confunde, embora se comunique, com o microcosmo humano (CLAVAL, 2014).

Anos mais tarde, a separação entre ser humano e natureza se complementa de maneira mais intensa. Nos séculos XVI e XVII, de fato, existe uma separação total entre o homem e a natureza, aliada à ideia do período clássico de controle, de domínio do primeiro sobre o segundo. Aplica-se no estudo da natureza, agora, um racionalismo emergente e procura-se entendê-la segundo os novos descobrimentos da física e da matemática. 
Consoante Boaventura de Souza Santos, opera-se, nesse momento, uma cisão total entre o humano e o mundo natural: de um lado repousa uma natureza passiva e inerte; de outro se eleva o homem ativo, dominador do mundo. Escreve o autor:

\begin{abstract}
A natureza é tão só extensão e movimento; é passiva, eterna e reversível, mecanismo cujos elementos se podem desmontar e depois relacionar sob a forma de leis; não tem qualquer outra qualidade ou dignidade que nos impeça de desvendar os seus mistérios, desvendamento que não é contemplativo, mas antes ativo, já que visa conhecer a natureza para dominar e controlar. Como diz Bacon, a ciência fará da pessoa humana o senhor e o possuidor da natureza (SOUZA SANTOS, 1995, p.4).
\end{abstract}

Augustin Berque, por seu turno, destaca o afastamento, o recuo (retrait du sujeit) em relação ao mundo, ao objeto. Diz: "estabelecendo uma dualidade entre ele mesmo e as coisas, com efeito, o sujeito moderno é retirado do mundo ambiente, por considerar doravante este recuo, como um objeto decisivamente distinto dele mesmo (BERQUE, 1996, p.22).

O afastamento do sujeito em relação ao objeto, sua apreensão na qualidade concreta, de extensão, leva a uma geral objetivação do mundo onde os fenômenos são conhecidos pelos seus aspectos físicos e materiais, quantificados e descritos em função de suas expressões mecânicas e numéricas.

É, afinal, a linguagem matemática e as explicações mecanicistas da física que descobrem e explicam as leis que regem a natureza e determinam as causas dos fenômenos.

Quando Galileu disse que a natureza é escrita em linguagem matemática, ele quis dizer que, além das manifestações sensíveis (os fenômenos que nós percebemos diretamente), a razão última da realidade não é outra que aquela que o espírito humano pode alcançar pela matemática, porque o universo ele mesmo é matemático: a teoria não pode somente representar o mundo, mas coincidir com suas leis internas (BERQUE, 1996, p.30).

Contra essa visão dicotômica da ciência moderna, Vidal de La Blache, já no final do século XIX início do XX, dizia não ser o homem "como um império dentro de um império", afirmando que não podemos entender a natureza e o homem como dois adversários em duelo, dois termos opostos: "ele [o homem] faz parte da criação vivente, é seu colaborador mais ativo. Ele não age sobre a natureza senão nela e por seu intermédio" (LA BLACHE, [1903] 2012, p. 103).

Também para Albert Demangeon, discípulo de La Blache, a sociedade não se relaciona com uma natureza puramente considerada, mas antes com o meio 
geográfico. Desde os primeiros grupamentos humanos, o homem participa dos processos naturais, criando novas associações entre plantas e animais, transformando áreas desérticas pela irrigação, alterando o curso dos rios ou o modelado dos relevos, estendendo-se estas transformações sobre vastas regiões (DEMANGEON, 1942, p. 12-13).

A sociedade, então, vive numa natureza já modificada, já convertida numa natureza humanizada. "Assim, as obras humanas, resultantes de todo o passado da humanidade, contribuem elas mesmas a constituir o ambiente, o entorno, o meio geográfico que condiciona a vida dos povos" (DEMANGEON, 1942, p. 13).

Hartshorne caminha na mesma direção ao considerar os conceitos de natural e humano; conceitos puramente teóricos. Para o geógrafo, quando o homem entra em cena a paisagem natural está perdida para sempre.

\footnotetext{
Verifica-se que os aspectos comumente julgados 'naturais' são produzidos pela natureza e pelo homem em conjunto; do mesmo modo, aspectos geralmente considerados de origem humana, terão sido o produto da interação de fatores humanos e naturais, em determinada época do passado" (HARTSHORNE, 1978, p. 54).
}

A propósito, em tempos mais modernos, Milton Santos indaga se hoje ainda é pertinente distinguir o meio ecológico e as obras produzidas pelo homem. Segundo Santos (2014), o homem já encontra na sua existência um meio trabalhado sobre o qual ele opera, sendo artificial separar meio natural de meio não natural. $O$ meio ecológico torna-se, no decorrer da história humana, cada vez mais modificado:

\footnotetext{
Dessa forma, o que em realidade se dá é um acréscimo ao meio de novas obras dos homens, a criação de um novo meio a partir daquele que já existia: o que se costuma chamar de 'natureza primeira' para contrapor à 'natureza segunda' já é natureza segunda. A natureza primeira, como sinônimo de 'natureza natural', só existiu até o momento imediatamente anterior àquele em que o homem se transformou em homem social, através da produção social (SANTOS, 2014, p. 19).
}

Uma contribuição valorosa, que mostra como homem e natureza estão intrinsecamente ligados, é dada por David Drew (2014), cujas análises deixam claro como a atividade humana participa de uma gama variada de processos físicos, químicos e biológicos, estabelecendo novas condições de equilíbrio.

O caráter dos solos, por exemplo, é determinado pela ação do homem que, a nível local, diz Drew, "assume maior significado que todos os demais fatores naturais em conjunto" (DREW, 2014, p. 47). De forma análoga, o padrão de distribuição de plantas e animais que, em função dos interesses humanos, foram controlados, 
eliminados de certos locais ou introduzidos em novas áreas. Nem mesmo a ausência física do homem em dada área, conforme reconhece Drew, "significa obrigatoriamente que a sua influência não se faça sentir" (DREW, 2014, p. 15), dado o princípio da conexão que une todos os fenômenos terrestres.

O homem participa da natureza não apenas de forma material, mas a própria percepção do que é natureza está em função das épocas e das sociedades consideradas. Ou seja, o próprio conceito de natureza possui um componente social e histórico e suas definições e os elementos nela contidos variam de um lugar e tempo a outro.

A natureza é o que se procura nela, observa Lenoble (2002).

Não era possível descobrir 'descrições' mecanicistas dos fenômenos enquanto se representasse a Natureza como uma Mãe providencial, muito simplesmente porque não se procurava tal coisa. Não era possível 'descrever' a evolução das espécies enquanto o homem se fizesse passar por protótipo das coisas e esse protótipo fosse concebido como rigorosamente imutável (LENOBLE, 2002, p. 30. Grifos do autor).

Desse modo, continua o autor, a concepção de mundo depende menos de ideias científicas e reflete mais "necessidades morais e sociais, até mesmo desejos inconscientes" (LENOBLE, 2002, p. 30).

Éric Dardel, na mesma ordem de ideias, também entende que a percepção que se tem da natureza se constrói a partir dos desígnios dos homens, de sua história presente e passada e de seus valores. Fala o autor: "[o] espaço material não é, de forma alguma, uma coisa indiferente, fechado sobre ele mesmo, de que se dispõe ou que se pode descartar (...). A planície só é 'vasta', a montanha só é 'alta', a partir da escala humana, à medida de seus desígnios" (DARDEL, 2011, p.8).

Assim como a noção de natureza é construção social, dependente do tempo e do espaço, falar em natureza a partir do ecúmeno é falar também de uma elaboração social. Destarte, natureza já é uma natureza humanizada, segunda natureza. A natureza, no contexto do ecúmeno, deve ser vista dentro do tempo histórico, cultural, simbólico inerente às sociedades, configurando-se como uma realidade física e fenomenal:

a natureza é, com efeito, o que em si não tem sentido ni par ni pour I'homme, mas que tem um sentido dans l'homme et autour de l'homme (...). A natureza é forçosamente traduzida em termos próprios a uma cultura; ela é integrada no mundo que o homem é capaz de conceber, perceber e organizar (BERQUE, 1990, p.51). 
No ecúmeno, o meio ecológico não figura separado do homem, mas integrase, junto à dimensão técnica e simbólica da humanidade, como base da existência humana. Ou seja, o ecúmeno define-se como a Terra enquanto habitada pelo homem, enquanto condição de vida. Nas palavras de Berque:

o ecúmeno é o conjunto das condições do meio humano, no que ela tem de propriamente de humano, mas não menos de ecológico e físico (...) o ecúmeno é uma relação: a relação a um só tempo ecológica, técnica e simbólica da humanidade com a superfície terrestre (BERQUE, 2010, p.17).

No ecúmeno, o mundo é a base da existência humana, um prolongamento do seu ser. Não há estranhamento entre a coisa extensa e a coisa pensante, entre a res extensa e a res cogitans de Descartes, pois o mundo participa do próprio ser do homem, e é este amálgama que Berque denomina ecúmeno. Este, como "conjunto das condições do meio humano, entende ontologicamente o ser humano para além do paradigma da ciência moderna, abordando a relação da humanidade com a superfície terrestre na sua substância, a um só tempo, técnica, simbólica e ecológica" (BERQUE, 2010).

O ecúmeno constitui-se, portanto, como algo de essencialmente humano, social na sua essência. Somos parte do meio onde vivemos, num movimento do ser em direção ao mundo e uma interiorização do mundo no corpo social.

Éric Dardel talvez expresse melhor essa ideia quando em sua obra escreve:

Amor ao solo natal ou busca por novos ambientes, uma relação concreta liga o homem à Terra, uma geograficidade (géographicité) do homem como modo de sua existência e de seu destino (...). Medo, admiração, simpatia, participamos ainda, por mais modernos que sejamos, por um acordo ou desacordo fundamental, do ritmo do mundo circundante. Entre o Homem e a Terra permanece e continua uma espécie de cumplicidade no ser (DARDEL, 2011, p. 2-6).

Mais a frente complementa:

A terra, como base, é o advento do sujeito, fundamento de toda a consciência a despertar a si mesma; anterior a toda objetivação, ela se mescla a toda tomada de consciência, ela é para o homem aquilo que ele surge no ser, aquilo sobre o qual ele erige todas as suas obras, o solo de seu hábitat, os materiais de sua casa, o objeto de seu pensar, aquilo a que ele adapta a sua preocupação de construir e erigir" (DARDEL, 2011, p. 41).

Em resumo, existe uma geograficidade primordial na relação do homem com o mundo, relação compreendida como "a inscrição do terrestre no humano e do homem sobre a Terra, de tal modo que nem o humano nem o terrestre podem ser geograficamente pensáveis um sem o outro" (BESSE, 2011, p. 112). 
A relação ecumenal desenvolve-se dentro de um movimento passivo e ativo, quer dizer, a sociedade transforma o meio em que vive material e simbolicamente, mas incorpora também forças inelutáveis do meio. Se, por um lado, são mais claras e evidentes as mudanças operadas pelo homem no meio, por outro, a parte que cabe ao meio técnico, cultural e ecológico na formação da sociedade é mais sutil, e as formulações que tentam explicá-las não raras vezes caem num determinismo simplista.

\subsubsection{Ecúmeno, mediance e ecosimbolicidade}

$\mathrm{Na}$ teoria de Berque, o homem habita a superfície terrestre conforme um sentido geral tomado na formação do ecúmeno. Quer dizer, existe uma direção predominante, uma identidade específica, tanto material quanto simbólica, na relação do homem com o meio. Diz Berque: "A mediance se acha definida como o sentido ou a idiossincrasia de um certo meio, quer dizer, a relação de uma sociedade com seu ambiente" (BERQUE, 2010, p. 206).

No desenvolvimento do ecúmeno, nessa direção, os esforços na apropriação da natureza e as decorrentes transformações promovidas pelo homem seguem caminhos que se particularizam em relação uns aos outros; "tais áreas, tais homens", para lembrar a expressão do mestre francês. A mediance expressa e reproduz, pois, as relações específicas de uma sociedade com seu ambiente.

Mas, esclarece o autor em outra passagem a respeito da mediance: "a mediance não é somente uma subjetivação do mundo. A trajetividade que a funda não é a subjetividade. Na mediance, há tanto uma assimilação do sujeito ao ambiente quanto uma assimilação do ambiente ao sujeito" (BERQUE, 1996, p.102).

A trajetividade que o autor cita significa a participação, a existência ontológica que a sociedade mantém com o meio. Isto é, a relação do homem com a superfície terrestre se dá de forma mais complexa que uma simples consideração sujeito/objeto, algo mais que o homem sobre a natureza ou a natureza sobre o homem. Diz o autor:

Coloquemos de imediato que este movimento não pode ser compreendido nos termos dualistas sujeito/objeto. O meio humano é uma relação, não um objeto (...). Nós participamos ontologicamente desta relação, como participam as coisas do nosso meio; o que significa que nosso ser e o deles se sobrepõem ou mesmo se identificam em certa medida (...) a ontologia 
das coisas força, então a admitir que o mundo ecumenal do ser - que é dizer tudo simplesmente a realidade - não revela nem propriamente 0 objetivo, nem propriamente o subjetivo. Este modo, eu o chamo de trajetivo (trajectivité) (BERQUE, 2010, p. 142-148).

A trajeção, portanto, significa a constituição conjunta dos seres, a confluência ontológica do mundo no ser humano e do homem no mundo. Esta ideia, pois, supera a configuração de dois polos opostos cujas tentativas de integração não acabam com a dicotomia. O homem é a natureza na medida em que ela faz parte do seu ser e a natureza é humana nas técnicas e símbolos que incorpora.

\begin{abstract}
Ora, este sentido [mediance] vem justamente do fato que a relação em questão é dissimétrica. Ela consiste com efeito na bipartição de nosso ser em duas "metades" que não são equivalentes, uma investida no meio ambiente [environnement] pelas técnicas e símbolos, outra constituída de nosso corpo animal. Estas duas metades não equivalente são entretanto unidas. Elas fazem parte do mesmo ser. Deste modo, esta estrutura ontológica faz sentido por ela mesma, em estabelecendo uma identidade dinâmica a partir destas duas metades, uma interna, outra externa, uma psicologicamente individualizada (o topos que é nosso corpo animal), outra difusa no meio (a chôra que é nossa corpo medial) (...). A médiance, é o momento estrutural instaurado pela bipartição, específica ao ser humano, entre corpo animal e um corpo médial (BERQUE, 2010, p. 206).
\end{abstract}

Nesta direção, o habitar do homem no mundo é de ordem ecossimbólica, ou seja, a presença do homem no mundo implica dimensões materiais e simbólicas, uma variável biológica e outra de ordem axiológica na apropriação do meio (BERQUE, 1996).

A ecossimbolicidade do ecúmeno implica que "todos os lugares são, sempre, carregados de valores humanos" (BERQUE, 1996, p. 80). Nada pode existir por si mesmo, diz Augustin Berque, mas antes, em referência à existência humana. A chuva, exemplifica o autor, só existe porque nós a percebemos e a interpretamos (BERQUE, 1996).

No ecúmeno, portanto, todos os seres são ecossimbólicos; é onde se exprime nossa relação com o mundo. É por esta razão, conclui Berque, que a relação ecumenal é também uma relação ética.

\title{
2.2.3 Mediance e ideologia geográfica
}

Tomando o universo subjetivo de apropriação humana do mundo, é possível construir um diálogo entre o conceito de mediance com o conceito de ideologias geográficas desenvolvidas por Antônio Carlos Robert Moraes. 
Assim como a mediance, enquanto subjetivação do mundo, cada sociedade desenvolve, de acordo com Moraes, um discurso geográfico sobre os espaços onde vivem: "a relação dos homens com a natureza implica níveis de percepção do meio que os abriga. A construção do hábitat necessariamente envolve projeções, préideações, avaliações, enfim formas de consciência do espaço" (MORAES, 2005, p. 2).

Os discursos geográficos forjados no seio das sociedades manifestam-se em várias esferas, seja na literatura, na mídia, na política e no Direito, conformando o pensamento dos grupos sociais, do Estado e dos agentes privados a respeito do espaço.

Vinculando este discurso geográfico às práticas políticas, Moraes desenvolve o conceito de ideologia geográfica: "as ideologias geográficas alimentam tanto as concepções que regem as políticas territoriais dos Estados, quanto à autoconsciência que os diferentes grupos sociais constroem a respeito do seu espaço e de suas relações com ele" (MORAES, 2005, p. 44).

\subsubsection{Ecúmeno e paisagem}

A expressão material da relação ecumenal dá-se na paisagem. A paisagem mostra concretamente a integração do homem com a superfície terrestre, revelando as transformações ocorridas e os sentidos da mediance existentes em cada período.

A paisagem não se configura apenas com os elementos do mundo natural, mas, antes, ela é animada, de forma trajetiva, pela ação do homem se apropriando do meio. Nesse sentido, Augustin Berque assevera:

Nós podemos estudar a morfologia do ambiente do ponto de vista das ciências naturais, e chamar este objeto de 'paisagem' (tal como a ecologia da paisagem); mas é necessário ser consciente de que, agindo assim, nós abstraímos do mundo sua própria existência e aquela dos outros humanos, os quais podem ter com este ambiente todo uma outra apreciação que aquela que nós reunimos no termo paisagem (BERQUE, 2010, p. 261).

Sendo a trajetividade o caráter essencial de sua formação, Berque fala da existência, da existência do homem no mundo na qualidade de paisagem. Diz o autor: "Nós não estamos imersos apenas biologicamente no ambiente; ele condiciona também nossa identidade e nossa personalidade pelo balanço dos 
valores que ele nos agrega. Ou seja, como paisagem" defende o autor (BERQUE, 1994, p. 26).

Éric Dardel também enxerga na paisagem este atributo existencial quando diz ser a paisagem a "ligação existencial com a Terra, ou, se preferirmos, sua geograficidade original: a Terra como lugar, base e meio de sua realização" (DARDEL, 2011, p. 31). Para o autor, ainda, a paisagem é "inserção do homem no mundo, lugar de combate pela vida" e "expressão fiel de sua existência".

Dardel, segundo Besse, indica a totalidade da paisagem porque esta é inserção do homem no mundo: "é através da paisagem que o homem toma consciência do fato de que habita a Terra" (BESSE, 2011, p. 199). Jean-Marc Besse diz ser a paisagem, na obra de Dardel, a expressão da existência, "portadora de um sentido, porque é marca espacial do encontro entre a Terra e o projeto humano" (BESSE, 2006, p. 92).

A paisagem, se é condição existencial do homem na Terra, porta as marcas desta presença humana, ou seja, a paisagem é, segundo terminologia de Berque, ao mesmo tempo empreint (marca, impressão) e matrice (matriz). Marca, uma vez que a ação do homem no ecúmeno transforma a fisionomia da Terra, imprimindo-lhe uma identidade que é sua. Se paisagem tem uma instância material, física, ela é um material já trabalhado, talhado pela atividade humana. Matriz porque ela inspira, guia ou constrange a atividade humana (BERQUE, 1996). "Claramente, a paisagem também chama por formas particulares de pensamento e até inspiram certas ideias" (BERQUE, 2013, p.1), afirma o autor.

Tomando o caso de uma cidade, Berque exemplifica:

a vila é então uma marca da ação humana. A longo prazo todavia, a materialidade mesmo da cidade torna-se uma matriz da ação humana. Ela inspira, guia, constrange a obra dos arquitetos, 0 regulamento dos urbanistas, o comportamento dos habitantes (BERQUE, 1996, p. 155).

Possivelmente, as marcas humanas na paisagem chamam mais a atenção, mas não menos intrigante e controversa é a força da paisagem como matriz. 


\subsubsection{Ecúmeno: totalidade e particularidade}

No contexto de expansão do ecúmeno para toda a Terra conhecida, Vidal de La Blache, ao analisar a conformação das regiões e paisagens francesas, sublinhava os princípios da totalidade (ou unidade terrestre) e da particularidade na apreensão dos fenômenos geográficos.

Segundo La Blache, na esteira de Humboldt e Ritter, nada existe isolado no organismo terrestre, pois a Terra é um todo "cujas diferentes partes se esclarecem mutuamente" (LA BLACHE, 1894 apud RIBEIRO, 2012, p.44). A fisionomia de uma área, para o autor, depende de influências múltiplas e longínquas das quais importa determinar a origem.

Guilherme Ribeiro, ao apresentar Vidal a seus leitores, ressalta esta contribuição do mestre francês e reproduz um trecho significativo do autor, no qual se lê:

É preciso ir além e reconhecer que nenhuma parte da Terra contém em si mesma a sua explicação. Só se descobre o jogo das condições locais com alguma clareza quando a observação se eleva para além de tais condições, quando se é capaz de apreender as analogias naturalmente conduzidas pela generalidade das leis terrestres (...). Na realidade, a Terra é um todo cujas diferentes partes se esclarecem mutuamente. (LA BLACHE, 1894 apud RIBEIRO, p. 44).

O ecúmeno não escapa desta totalidade e particularidade na sua formação. Com efeito, ao habitar o mundo, o homem em sociedade se põe frente a totalidades naturais, técnicas, econômicas, simbólicas ao mesmo tempo em que as manipula e as expressa de forma particular, singular para cada porção da superfície terrestre.

As sociedades se desenvolvem em climas cujos regimes são globais ou sob economias cuja racionalidade é mundial. Ao mesmo tempo, no evolver da relação ecumenal, assume igual força as diferenças naturais e as especificidades técnicas, culturais, econômicas de cada sociedade.

O todo e a parte se combinam na relação ecumenal, portanto, numa reciprocidade de determinações e condicionamentos inescapáveis na integração do homem com a Terra e na formação da paisagem.

Milton Santos insiste também na noção de totalidade para a compreensão da realidade, principalmente em se tratando dos processos sociais. Para o autor, lembrando Wittgenstein, "a totalidade é o conjunto de todas as coisas e de todos os homens, em sua realidade, isto é, em suas relações, em seu movimento". Daí que o 
movimento de transformação social não se deve somente "à influência do movimento próprio das parcelas localizadas nas diferentes regiões, mas ao movimento global decorrente das forças mais gerais responsáveis pela distribuição geográfica das diversas variáveis sobre o conjunto" (SANTOS, 2004, p. 116).

Considerar a totalidade, contudo, não minimiza a importância das condições e manifestações locais dos fenômenos, os quais fornecem, justamente, a miríade de tons das regiões e paisagens. Cada área, região da superfície terrestre realiza uma parte da totalidade e manifesta os diferentes tipos e graus de integração dos fenômenos. Cada área é uma particularidade, uma singularidade na ligação dos fenômenos e na relação do homem com a natureza.

Os homens vivem no espaço na dimensão do chôra, considera Berque. Partindo das análises platonianas, Berque (2010) diz ser o ecúmeno "a abertura pela qual vêm à existência os seres que constituem o mundo" (BERQUE, 2010, p. 31). Ao contrário de topos, que refere-se à localização ou se situa um corpo, o chôra, é um lugar "genitor", um lugar dinâmico que participa do desenvolvimento das coisas. "A chôra é um lugar que participa daquilo que ali se encontra; e é um lugar dinâmico, a partir do qual advém qualquer coisa de diferente, não um lugar que encerra as coisas na identidade do seu ser" (BERQUE, 2010, p.34).

É essa particularidade nas combinações que dotam cada superfície de integrações específicas, as quais Hartshorne propõe estudar quando define a Geografia como o estudo da diferenciação de áreas (HARTSHORNE, 1978).

Nas particularidades do ecúmeno existe, igualmente, "quelque chose qui exprime le général'. O ecúmeno reflete o todo não apenas na sua expressão ecológica, mas na qualidade de seres humanos: "a plena expressão da essência humana de cada um de nós é como tal uma expressão do todo que é a Terra" (BERQUE, 1996, p. 177).

A Terra é um todo, enuncia La Blache, mas suas partes expressam de maneira variada esta unidade. Em cada área - ou em cada região, como denominou o autor - os fenômenos terrestres apresentam-se e encadeiam-se de forma particular. Os fenômenos, embora obedeçam às leis gerais na unidade terrestre, ocupam diferentes posições e extensões na superfície do globo, o que lhes atribui diferentes intensidades nas suas manifestações e ligações mútuas, configurando regiões determinadas. Assevera o autor: 
O que mais surpreende, depois que pudemos comparar sobre uma escala maior os fenômenos da superfície terrestre, é a maravilhosa variedade de combinações que eles apresentam. Em todos os lugares, tais fenômenos se mostram regidos por leis gerais, mas igualmente modificados por circunstâncias locais de solo, relevo, clima e pelo cruzamento entre todas as causas que concorrem a determinar a fisionomia das regiões (...) encadeamentos diferentes de fenômenos diversificam regiões que, em certos aspectos, são análogas. Cada região é a expressão de uma série particular de causas e efeitos (LA BLACHE, 1899 apud RIBEIRO, 2012, p. 81).

O todo não exclui as partes. A natureza da integração dos fenômenos, as variadas combinações e intensidade das ligações estabelecidas são também variáveis que influenciam na conformação da paisagem. O homem encontra diferentes quadros naturais, diferentes manifestações da totalidade, as quais ele deve compor e achar soluções para responder às necessidades de habitação, alimentação e defesa.

La Blache afirma:

Constatamos assim as diversidades, cujo princípio, como podemos nos convencer, reside sobretudo nas diferenças de materiais fornecidos pela natureza ambiente. Mas, por comparação, chegamos também à constatação de que, para além das variantes locais, existem formas de existência e modos de civilização abraçando grandes extensões e numerosos conjuntos de seres humanos" (LA BLACHE, 1902 apud RIBEIRO, 2012, p. 87).

No ecúmeno, portanto, a relação do homem com a superfície terrestre obedece a condicionantes locais e, igualmente, se expressa enquanto totalidade. Os vínculos dos homens com o meio estão também em função da totalidade dos processos humanos e naturais, e não apenas das manifestações locais dos fenômenos. Destarte, as migrações, os contatos técnico-culturais, as estruturas político-econômicas mais gerais e os processos naturais globais entram no jogo das relações dos homens com a natureza.

$\mathrm{Na}$ materialidade da paisagem ou na sua camada mais simbólica e valorativa, enfim, também se expressa o homem enquanto totalidade manifesta na diversidade de suas particularidades.

\subsubsection{O caráter histórico do ecúmeno}

"O mundo, com efeito, tem uma história", afirma a certa altura Augustin Berque. História do mundo, porém, que é a história do próprio homem, pois na 
realidade do mundo o concreto (concretus do latim "crescer junto") e o homem possuem uma história comum. Tem-se, portanto, um caráter temporal na configuração do ecúmeno e da paisagem (BERQUE, 2010).

De fato, a relação do homem com a superfície terrestre é uma relação de conteúdo histórico. As sociedades carregam consigo a vivência que tiveram no passado com o meio onde habitaram, onde trabalharam e por onde circularam, acumulando formas de conhecer e de se apropriar do ambiente que se traduzem na própria forma de ser.

Vidal de La Blache, por sua formação inicial de historiador, não deixou escapar a importância do tempo na configuração das relações do homem com o meio e na formação dos gêneros de vida e da paisagem. É o que deixa claro, em certa passagem, ao trabalhar o conceito de gênero de vida na Geografia Humana, quando diz: "os primórdios podem explicar o que vem em seguida; as circunstâncias iniciais regeram, na maioria das vezes, o sentido da evolução ulterior" (LA BLACHE, 1911 apud RIBEIRO, 2012, p. 141).

Vidal tinha, porém, a ideia de um tempo geográfico diferente de tempo histórico, pois "o relógio do geógrafo não é exatamente o mesmo que o do historiador", afirmava (LA BLACHE, 1914 apud LIRA, 2012, p. 90).

Analisando esta noção de tempo no autor francês, Larissa Alves Lira comenta:

\begin{abstract}
Apoiado na literatura histórica, ele conseguiu ver na paisagem um tempo que se materializava no espaço segundo lógicas incompreensíveis ao olhar do historiador de gabinete. Círculos sucessivos, estendendo as periferias, avanços e recuos do espaço em uso, fluxos e difusão das técnicas, um jogo de balança entre os sistemas avançados e atrasados de acordo com períodos de crise - os homens e as técnicas são a expressão inelutável da cronologia da obra humana em contato com a natureza (LIRA, 2012, p. 90).
\end{abstract}

Albert Demangeon chamava igualmente a atenção para a historicidade da interação homem-natureza. Dizia: "todo o estudo desta conquista do solo se faz com base na história" (DEMANGEON, 1942, p.17). Ou seja, para o autor, é preciso recorrer à história, remontar ao passado para examinar a evolução dos fatos.

O tempo é imprescindível na consideração do ecúmeno, afinal. Ele se forma no acúmulo de instrumentos técnicos, na sucessão das relações sociais e de produção que se afirmam no caráter geral da paisagem.

Mas considerar a ligação do homem com o meio de forma histórica requer que tomemos o cuidado de levarmos adequadamente em conta o período que tal ou 
qual relação se estabeleceu. Quer dizer, a experiência dos grupos sociais no meio em que vivem se efetiva e consolida-se em função da totalidade de cada período, do conjunto de sistemas técnicos e do conjunto de valores predominantes em cada época.

A relação se estabelece não em função de um elemento técnico ou de um único valor pretérito, mas segundo a soma dos sistemas ao qual pertencem, porquanto cada sistema técnico forma um todo coerente com os sistemas sociais, econômicos, políticos e culturais. Do contrário, corre-se o risco de perder a verdadeira natureza de sua configuração.

Nesse sentido, Milton Santos nos alerta a respeito da consideração histórica na análise do espaço:

Se um elemento não é considerado como um dado dentro do sistema a que pertence (ou ao qual pertencia na época da sua apresentação), não se está utilizando um enfoque espaçotemporal. A mera referência a uma situação histórica ou a busca de explicações parciais concernentes a um ou outro dos elementos do conjunto não são suficientes (...). Sozinha, uma variável é inteiramente carente de significado, como o é fora do sistema ao qual pertence (SANTOS, 2014, p. 36-7).

Assim, "a cada momento da história local, regional, nacional ou mundial, a ação das diversas variáveis depende das condições do correspondente sistema temporal" (SANTOS, 2014, p. 36).

A evolução social do ecúmeno, com efeito, desenvolve-se mantendo as aprendizagens passadas de apropriação do meio, ao qual são incorporadas, por outro lado, formas atuais de uso.

Há uma continuidade histórica na relação do homem com o meio, certas margens de permanência que condicionam o progresso posterior da relação do homem com o mundo.

\subsubsection{O ecúmeno e a dimensão técnica}

Uma das características essenciais do ecúmeno e da paisagem encontra-se na sua dimensão técnica. Toda uma gama de ferramentas, instrumentos e equipamentos sociais permeiam a existência do homem junto ao meio.

Milton Santos (2004) não deixa dúvida, realmente, ao afirmar que a principal forma de relação entre o homem e a natureza é dada pela técnica, em tal medida que hoje, no mundo contemporâneo, vivemos o chamado período tecnológico: 
"dentre as múltiplas denominações aplicadas ao nosso tempo, nenhuma é mais expressiva que a de período tecnológico" assevera o autor (SANTOS, 2004a, 16).

Conforme Augustin Berque, a técnica surgiu com nossos ancestrais "no mesmo processo onde sua espécie emergiu dos primatas", processo que se deu concomitantemente quando o ecúmeno surge a partir da biosfera. Um triplo e mútuo engendramento ocorreu, segundo o autor,: a hominização ("a transformação física do animal em humano"), a antropização ("a transformação objetiva das coisas pela técnica") e a humanização ("a transformação das coisas pelos símbolos"), submetendo o evolver do ecúmeno a um triplo devir (BERQUE, 2010, p. 154-5). "Assim o ecúmeno nasceu, quer dizer emergiu, da biosfera por um processo de interação entre a hominização, a antropização e a humanização" (BERQUE, 2010, p. 159).

A humanidade, ao longo de sua história, atravessou diferentes fases tecnológicas, as quais, por sua vez, permitiram modos variados de integração com a natureza. Desde as técnicas mais simples até o período técnico-científicoinformacional em que vivemos, segundo Santos (2004), a percepção e apropriação do meio se deu em função do desenvolvimento técnico alcançado pela sociedade.

De fato, alterações na natureza e na qualidade das técnicas, seu grau de aperfeiçoamento, ensejam apreensões distintas do mundo, quando não percepções humanas antagônicas sobre a natureza circundante. Por outro lado, e concomitantemente, o próprio ser do homem, seus modos de pensar, agir e fazer acompanham a evolução das técnicas.

É nesse sentido que Northrop sustenta que:

o homem contemporâneo é, a um só tempo, criador e cativo da civilização tecnológica. Seus instrumentos relacionaram-no com a terra de uma nova maneira. Esta nova maneira refletiu de volta sobre ele mesmo, formando e alterando seus valores (NORTHROP, 1956, p. 1052).

Northorp, sem esquecer a existência de técnicas em todas as sociedades, classifica as civilizações segundo a essência do desenvolvimento tecnológico - uma de formulação abstrata e outra empírica. Para o autor, existem civilizações tecnológicas e civilizações não tecnológicas, conforme sua denominação, cujas diferenças residem nas formas mediata ou imediata de apreensão da natureza e elaboração do conhecimento. 
Uma civilização não tecnológica pode ser identificada pela apreensão imediada ou por um senso indutivo puro dos objetos; "seus objetos científicos são definidos em termos de propriedades sensíveis diretas" (NORTHROP, 1956, p. 10534). Uma civilização tecnológica, por outro lado, se caracteriza pela tomada dedutiva dos objetos, pelas formulações teóricas construídas a priori; "seus objetos e relações cientificas elementares básicas não são diretamente observáveis" (NORTHROP, 1956, p. 1053).

Milton Santos (2004), refletindo também sobre o momento "quando tudo era meio natural" afirma que a técnica estava ligada às dádivas da natureza "com a qual se relacionavam sem outra mediação"; as técnicas não tinham existência autônoma, pois eram elaboradas de forma orgânica, simbiótica com o meio local.

As motivações de uso eram, sobretudo, locais, ainda que o papel do intercâmbio nas determinações sociais pudessem ser crescentes. Assim, a sociedade local era, ao mesmo tempo, criadora das técnicas utilizadas, comandante dos tempos sociais e dos limites de sua utilização. (SANTOS, 2004, p. 235-6).

O que caracteriza as técnicas atuais, por outro lado, é seu casamento com a ciência moderna, de inspiração decartiana e newtoniana, cuja racionalidade obedece a modelos de representação da realidade elaborados anteriormente à investigação empírica.

Milton Santos acrescenta ainda a informação como componente da elaboração técnica, consubstanciando-se o meio, no fim, como meio técnicocientífico-informacional. Conforme o autor salienta, no período atual, os objetos técnicos são, a um só tempo, objetos técnicos e informacionais; "na verdade, a energia principal de seu funcionamento é também a informação" (SANTOS, 2004, p. 238).

Assim, enquanto numa civilização tecnológica a natureza é apreendida em função de postulados axiomáticos teoricamente construídos, cuja validade dedutiva é dada a posteriori, numa civilização não tecnológica o conhecimento sobre a natureza deriva de sua apreensão sensível direta. Como consequência da natureza tecnológica ou não das sociedades, as ferramentas, os valores éticos, estéticos e legais dos dois tipos de civilização diferem de forma correspondente e engendram relações próprias com o mundo.

Northrop resume da seguinte forma: 
É nesta diferença entre ferramentas feitas de objetos científicos manipulados de forma indutiva simples, imediatamente sensíveis e as ferramentas derivadas de objetos e relações científicas axiomaticamente construídas e dedutivamente formuladas que a diferença de natureza entre uma civilização não tecnológica e uma tecnológica consiste. É na diferença dos significados e materiais e nas suas formas providas pela apreensão e sensação imediata do homem e da natureza comparado com o sentido, material e formas providas pela construção axiomática, homem e natureza concebidos dedutivamente, com seus mais elementares e objetos e relações científicos universais, que a diferença de tipo entre a ética, a estética e os valores legais de uma civilização não tecnológica daquela de uma civilização tecnológica tem suas bases (NORTHROP, 1956, p. 1054).

A existência humana no mundo, o ecúmeno e a formação da paisagem, portanto, sofrem uma influência constitutiva decisiva das técnicas. Sua integração ecológica com o mundo está indissociado da essência do desenvolvimento técnico.

Na verdade, a ideia da dimensão técnica no conceito de ecúmeno é de uma exteriorização de nosso corpo animal no ambiente, consubstanciando o que Berque denomina de corpo medial. O ecúmeno prolonga, concreta e simbolicamente, nossa carne, nosso corpo animal no ambiente: "ela é a trajeção de nossa corporeidade nas coisas de nosso ambiente" (BERQUE, 2010, p. 157).

Por isso a negação de uma perspectiva sujeito/objeto, homem/natureza, porquanto o meio é o nosso próprio ser. O corpo medial, para Berque, "é a trajeção do humano no ambiente [environment] o que justamente faz dele um meio humano" (BERQUE, 2010, p. 170).

É o sistema técnico que promove esta "exteriorização de nossa corporeidade", que artificializa a natureza e torna o ambiente ontologicamente parte do nosso ser constitutivo. Concomitantemente, esse ambiente artificializado também nos artificializa, isto é, o movimento de exteriorização do ser humano na formação do ecúmeno é, ao mesmo tempo, um movimento de interiorização do mundo sobre nosso corpo animal e nosso ser espiritual. A trajeção ecumenal é um "vai e vem [váet-vient]": "toda exteriorização por meio de um dispositivo técnico se acompanha de uma interiorização simultânea de suas modalidades de funcionamento" (PICON, 1998 apud BERQUE, 2010, p. 339) ${ }^{9}$.

Por outro lado, efetivar a trajeção no ecúmeno tem, por consequência, a alteração da própria existência humana no sentido de que os ritmos de vida ou a própria forma de pensar e sentir do homem são também transformados junto com a técnica.

\footnotetext{
${ }^{9}$ PICON, Antoine, 1998 : La ville territoire des cyborgs, Éd. de l'Imprimeur.
} 
Cada nova técnica nos leva a uma nova percepção do tempo, pondera Milton Santos:

(...) cada nova técnica não apenas conduz a uma nova percepção do tempo. Ela também obriga a um novo uso do tempo (...) a influência das técnicas sobre o comportamento humano afeta [também] as maneiras de pensar, sugerindo uma economia de pensamento adaptada à lógica do instrumento (SANTOS, 2004, p. 186).

A propósito, Georges Friedmann (1968), valendo-se dos termos de civilização maquinista e civilização pré-maquinista, ressalta os efeitos da tecnologia nos ritmos da vida cotidiana. "Numerosos exemplos mostram que estas técnicas, frequentemente ligadas aos ritmos, mergulham profundo nas tradições de uma coletividade" (FRIEDMANN, 1968, p. 18).

Quando o homem estava mais próximo de uma civilização não tecnológica, os ritmos de vida e trabalho eram ditados pelos ciclos naturais. Diz o autor: "Na civilização pré-maquinista do Ocidente, onde o indivíduo estava muito mais dependente do que hoje dos elementos, terra, estações, animais, divisão dos dias e das noites, o trabalho se achava constantemente sobre a pressão dos ritmos naturais" (FRIEDMANN, 1968, p. 18).

A análise de Georges Friedmann estende-se dos ritmos de vida e trabalho para a percepção do tempo, a sensibilidade, a mentalidade e o psiquismo humano. Desta forma, pergunta-se Friedmann, devemos acreditar que os modos de perceber e de sentir não são afetados na passagem de um meio natural para um meio técnico?

\footnotetext{
O meio natural (...) se acompanha de uma mentalidade diferente daquela dos homens do meio técnico (...) A mentalidade dos indivíduos, num grupo humano, é inseparável do conjunto de suas condições de existência e particularmente do estado dos conhecimentos das técnicas, e da linguagem que eles dispõem para se exprimir (FRIEDMANN, 1968, p. 25).
}

\subsubsection{Ecúmeno, paisagem e Direito}

\subsubsection{Teoria tridimensional do Direito}

Ecúmeno e paisagem comportam também, devemos considerar, a dimensão jurídica da sociedade. Com efeito, o Direito participa ativamente no habitar do homem na superfície terrestre. 
Pela teoria tridimensional do Direito elaborada por Miguel Reale, o Direito compõe-se de três elementos fundamentais: o valor, a norma e o fato. $\mathrm{O}$ valor é a projeção do espírito humano sobre os fenômenos, "a medida estimativa do fato" atribuindo-Ihes significado; a norma, "como medida de concreção do valioso no plano da conduta social"; e o fato "como condição de conduta, base empírica da ligação intersubjetiva" (REALE, 2002, p. 490).

Conforme esta teoria, a norma integra um fato juridicamente caracterizado e um valor que qualifica este fato, atuando na elaboração, interpretação e aplicação da lei. O Direito não se resume, pois, à lei, ao texto escrito, mas é composto também dos fatos (que passam por uma categorização jurídica) e dos valores ético morais predominantes na sociedade.

O Direito, além da consideração unicamente da norma, também opera uma subjetivação do mundo, atribuindo um caráter axiológico aos fatos. Existe sempre, assevera Reale, uma tomada de "posição estimativa do homem" em relação aos fatos do mundo. As leis jurídicas, diz, "marcam sempre uma posição espiritual, uma atitude crítica e valorativa do homem perante os fatos" (REALE, 2000, p. 200).

"O específico do homem é conduzir-se, é escolher fins e pôr em correspondência meios a fins", diz Miguel Reale nas suas apreciações sobre fins e valores.

\footnotetext{
A ação, em seu sentido rigoroso, ou o ato, é energia dirigida para algo, que é sempre um valor. O valor, portanto, é aquilo a que a ação humana tende, porque reconhece, em um determinado momento, ser motivo, positivo ou negativo da ação mesma (REALE, 2002, p. 368-9).
}

O fim como valor coloca a ação do homem enquanto dever ser, portanto, enquanto uma "solicitação de comportamento ou em direção para atuar" (REALE, 2002). Nesse sentido, o ecúmeno evolui segundo os fins e valores postos pela sociedade, sendo o Direito um elemento relevante deste evoluir.

O Direito é, com efeito, este complexo de valores que orientam a conduta humana conforme um dever ser. "Se a ação humana se subordina a um fim ou a um alvo, há direção, ou pauta assinalando a via ou a linha de desenvolvimento do ato. $A$ expressão dessa pauta de comportamento é o que nós chamamos de norma ou de regra” (REALE, 2002, p. 374).

O valor, entretanto, não prescinde do meio onde a sociedade vive e habita, o mundo físico que o cerca e envolve, assim como, por consequência, o Direito não 
pode pairar abstratamente acima do elemento fático que o compõe. As dimensões materiais e subjetivas da sociedade se constituem mutuamente na produção do Direito.

De fato, os homens direcionam as escolhas possíveis e os interesses de acordo com a variabilidade do meio ecológico bem como em função das diferenças socioculturais entre os diversos grupamentos humanos. Não é uma causalidade mecânica entre os elementos que determina o desenvolvimento da relação ecumenal, mas os fins que os homens se colocam enquanto sociedade que dão sentido e carregam de valores o ecúmeno. Assevera Berque: "no ecúmeno, causa e motivo se combinam na trajetividade da realidade. Ela está então a meio caminho entre a necessidade moral e a necessidade física" (BERQUE, 2010, p. 240).

São diversos os elementos do meio apropriados pela ação humana. Pelo ângulo da teoria tridimensional do Direito, Miguel Reale fala em termos de fatos que são os objetos de valoração pelo homem: fato é todo meio histórico, social, físico que envolve o homem no momento de agir. "Não há conduta humana (e o 'humano' aqui é redundante) que não se desenvolva na condicionalidade de um complexo de fatos (físicos, econômicos, históricos, estéticos, jurídicos, morais, religiosos)" assevera Reale (2002, p.381).

Os fatos nunca ocorrem isoladamente, mas, antes, configuram-se como um "conjunto de circunstâncias, estando o homem rodeado por uma série de fatores que solicitam sua atenção" (REALE, 2002, p. 530).

O fato humano, ou natural, é a base da origem do Direito, mas o Direito a ele não se reduz, pois como dito acima, é preciso a concorrência do elemento valorativo na conformação da lei. Daí que se configura um fato jurídico, diferente da mera consideração de um fato bruto, anterior a qualquer valoração jurídica. O fato jurídico é um fato já juridicamente qualificado, "um evento ao qual as normas jurídicas já atribuíram determinadas consequências, configurando-o e tipificando objetivamente" (REALE, 2000, p. 200). Reale acrescenta ainda: "é o motivo pelo qual não há, em Direito, fato bruto, pois o fato já deve conter algumas notas valorativas que permitam a sua correspondência ao fato-tipo previsto na regra de Direito. Em última análise, o fato-tipo é um módulo de valoração do fato possível na vida concreta" (REALE, 2000, p.203).

Na relação do ecúmeno, afinal, a esfera jurídica desempenha um papel de sobremodo importante ao instituir a medida de valorização dos fatos segundo o 
posto pelas regras de Direito. O sistema jurídico ao mesmo tempo em que carrega os valores de dada sociedade fornece também os valores do ecúmeno, dando sentido no seu movimento de trajecção. Os valores, as ações humanas, e a formação do ecúmeno são elementos constituintes de um mesmo processo.

Os valores representam, por conseguinte, o mundo do dever ser, das normas ideais segundo as quais se realiza a existência humana, refletindose em atos e obras, em forma de comportamento e em realizações de civilização e de cultura, ou seja, em bens que representam o objeto das ciências culturais (REALE, 2002, p. 187).

Por outro lado, a valoração jurídica dos fatos não obedece a valores transcendentes que independem do meio social; ao contrário, ela pertence a um universo de significação do espaço edificado em cada sociedade. "Uma certa ordem de valores resulta consagrada", lembra Miguel Reale.

Quando o poder social ou o poder estatal, em virtude de seu ato decisório, aperfeiçoa o nascimento de uma norma costumeira ou legal, uma certa ordem de valores resulta consagrada, tornando-se obrigatória: a norma não é, assim, um "objeto ideal", mas uma realidade cultural, inseparável das circunstâncias de fato e do complexo de estimativas que condicionam o seu surgir e o seu desenvolvimento (REALE, 1992, p. 61).

\subsubsection{Ecúmeno e temisfera}

Em termos axiológicos, a esfera jurídica que orienta valorativamente 0 desenvolvimento do ecúmeno, José Nicolau dos Santos define como temisfera, espécie do gênero psicosfera. Do conceito de noosfera enunciado por Pierre Chardin na primeira metade do século XX, Nicolau dos Santos deriva a ideia de temisfera, a esfera do pensamento jurídico, conceituada nos seguintes termos:

Dentro dessa esfera do pensamento, dessa esfera onde opera a razão humana, nesse envelope, nessa capa psíquica e imponderável de todas as camadas físicas e biológicas (biosfera), que integram a morfologia planetária, pode situar-se a marca mais constante e imperiosa da mente humana que é o Direito, constituindo assim uma esfera nova e específica, a qual chamaremos temisfera, ou seja, a esfera legal, o invólucro jurídico norteador e dominante das demais atividades geossociais (SANTOS, 1956, p. 308).

No aspecto material, também o conceito de temisfera se aproxima do de mediance, porquanto o professor paranaense bem lembra a dimensão concreta da 
"esfera de pensamento jurídico": assim como o "espírito religioso", a esfera do pensamento jurídico materializa na face da Terra "tribunais e parlamentos, aduanas e prefeituras, edificações onde as leis são elaboradas ou aplicadas, e que revelam sempre uma fisionomia adequada às funções que exercem" (Santos, 1954, p. 194).

José Nicolau dos Santos complementa o conceito de temisfera argumentando, por outro lado:

\begin{abstract}
Julgamos não ser a materialização do Direito em edifícios que assinale melhor a marcha do pensamento jurídico sobre a fisionomia do nosso planeta. Muito mais do que isso, a Terra está dividida em compartimentos estanques, fragmentada em nacionalidades independentes, repartida em Estados politicamente soberanos (...) As fronteiras são como extensas cercas configurando territórios, e, dentro delas, as leis e os costumes juridicamente aceitos diferenciam as atividades humanas, modelam e diversificam a mentalidade dos povos, criando além de uma simples 'paisagem humanizada" uma verdadeira e nítida paisagem espiritual, típica de cada nacionalidade (SANTOS, 1954, p. 195).
\end{abstract}

Justamente por estar fragmentada em nacionalidades independentes, por operar em superfícies de domínio estatal delimitadas, a esfera jurídica ou temisfera, se presta melhor a ser cartografada, considera Santos:

A validade espacial das jurisprudências estatais, a extensão e o domínio de cada soberania política decorrem sempre dentro de perímetros geográficos rigorosos e previstos. Por consequência, da noosfera ou da psicosfera, a manifestação mais importante, com possibilidade da mais rigorosa representação cartográfica é precisamente a esfera imperativa do Direito (Santos, 1954, p. 198).

\title{
2.2.9 Paisagem enquanto dimensão jurídica
}

A paisagem como marca e como matriz diz também da esfera jurídica de regulamentação humana. O Direito, sendo parte da relação ecumenal e ligado a mediance, é igualmente parte da paisagem.

A participação do Direito na paisagem pode assumir a forma ou o contorno dos elementos nela presente, como ilustram muitos padrões morfológicos observados na cidade ou no campo. É a 'paisagem marca' como definida por Berque.

Desse modo, a disciplina do Direito conduz a ação transformadora do homem em direções específicas, definindo formas paisagísticas de maneira determinada. $\mathrm{O}$ 
Direito se mostra impresso nas métricas das vias de circulação, nos padrões e arquiteturas urbanas e rurais ou no tamanho e contorno de áreas de proteção.

São estas marcas da lei na paisagem que Rutherford Platt, geógrafo norteamericano, traduz com o termo paisagem legal (legal landscape). Afirma Platt: "[A] lei como instrumento tanto do direito privado como do poder público é um instrumento sutil, mas onipresente na evolução das formas urbanas e é frequentemente discernível também na paisagem rural" (PLATT, 2004, p. 49).

O Direito participa da paisagem não só enquanto marca, mas também como matriz. Existe um conjunto de regras que se associam à paisagem em sua formação, tanto de forma material quanto simbolicamente, comandando, em função da força do Direito, os usos e os comportamentos em certos espaços paisagísticos.

$\mathrm{Na}$ medida em que o Direito assume formas concretas no espaço, a paisagem passa a influenciar o movimento geral da sociedade, pois ela é materialidade enquanto trajeção da mediance e, como tal, dotada de valor. No caso, valores trazidos pelo Direito e representando a força coercitiva das leis.

Nesta ordem de ideias, vale traçar alguns paralelos entre a paisagem como marca e matriz e os conceitos de território normado e território como norma desenvolvidos por Milton Santos e Ricardo Mendes Antas Júnior.

Tanto Milton Santos (2004) como Antas Junior (2005) chamam bastante a atenção para o fato de que o espaço geográfico assume uma dimensão normativa. Os autores trabalham a ideia do território como norma e território normado, no sentido de que este significa a normatização do território pelas ações e, aquele, a configuração territorial agindo como norma (SANTOS, 2004; ANTAS JUNIOR, 2005).

Milton Santos e Ricardo Mendes partem da ideia do espaço geográfico como um conjunto de objetos indissociáveis de um conjunto de ações. As normas estariam entre os objetos e as ações comandando os usos e funcionalidades do território.

Por um lado, as normas, em diferentes escalas (das internacionais às locais), agem como ações sobre espaços específicos, controlando em graus variados a dinâmica e os comportamentos da área - o território normado.

Por outro lado, as próprias formas do espaço geográfico induzem ações prédeterminadas - é o território como norma (SANTOS, 2004; ANTAS JUNIOR, 2005). Neste último sentido, cabe frisar o que Ricardo Mendes diz: humanizadas) não poupam a dinâmica social de atritos e condicionamentos, 
gerando, desse modo, uma forma peculiar de regulação. Na verdade, podese afirmas que a rigidez da norma jurídica e da forma geográfica elementos que, instrumentalizados, se prestam à regulação - compõem partes de um mesmo processo (ANTAS JUNIOR, 2005, p. 52).

É neste sentido que Antas Júnior fala em espaço geográfico como fonte material e não formal do Direito, justamente por essa qualidade "normativa" que os objetos e sua correlata organização têm. Explicando melhor a ideia, o autor assevera:

Indivíduos, grupos e/ou populações têm seus comportamentos constantemente submetidos a enquadramentos geradores de resultados "socialmente desejáveis". Essa coação produzida externamente aos sujeitos pode ter sua fonte numa materialidade apenas aparentemente inerte, uma vez que os conjuntos de objetos artificiais e humanizados que a constituem arranjam-se intencionalmente, de modo a obstaculizar dadas ações ou, ao contrário, a promover-Ihes a fluência (ANTAS JUNIOR, 2005, p. 54).

Em termos do Direito, a paisagem também possui essa normatização incidente que atua através das ações que ali de desenrolam, bem como age de maneira normativa trazida pela concretude tomada da lei. $O$ conjunto de regras que se associam à paisagem toma forma material (paisagem como marca) e assume uma intencionalidade específica, passando a influenciar a atividade humana (paisagem como matriz).

Em suma, paisagem e Direito participam de um mesmo processo de integração social com o meio. Seja separadamente, mas muitas vezes de forma indissociável, paisagem e Direito conjugam-se na formação do espaço de vivência do homem.

Esta inseparabilidade do Direito e da paisagem, tanto em termos materiais quanto no ambiente jurídico da área - a temisfera -, aproxima-se do conceito de splice proposto por Blomley et al., (2001).

Os autores tentam definir esta conjunção da lei e do espaço (os autores falam em espaço e não em paisagem) em termos de splice (literalmente, união, costura, encaixe), no sentido de que espaço e lei "são aspectos um do outro", que "constituem-se reciprocamente" e são elementos inseparáveis um mesmo fenômeno (BLOMLEY et al., 2001; BLOMLEY, 2003; DELANEY, 2003).

Diz Delaney:

Como outras práticas o Direito tem seus artefatos particulares locais; seus documentos e selos, seus textos, algemas, distintivos, cadeiras elétricas, e martelos, as micro espacialidades peculiares das salas das cortes, e assim por diante. Mas precisamente porque o imperialismo do Direito vis-à-vis a 
totalidade social, então todo o mundo material, todos os artefatos materiais da ordem cultural da modernidade, são instrumentos através do qual o legal (the legal) é realizado no mundo. O legal é incorporado, executado e instanciado em todos os corpos, em todos os lugares, e em todos os tempos. (...) Não é apenas o caso que 'o legal' torna-se inscrito em segmentos do mundo material (law-in-space). E não é apenas que a metáfora espacial confere uma medida de coerência para o discurso legal (space-in-law). O caso é também que o que nós chamamos "legal" é uma presença palpável no e entre (in and among) as coisas do mundo (DELANEY, 2003, p. 81-2).

A paisagem enfim, consubstancia as leis num feixe de totalidades, temporalidades e técnicas, formando o ambiente onde o homem vive. Destacandose o Direito, a paisagem materializa e assume valores presentes nas leis e disciplinas que regulamentam o comportamento humano. 


\section{3 ÉTICA AMBIENTAL}

Segundo Édis Milaré, a ética ambiental trabalha as relações humanas com o resto do planeta no intento de alcançar "bons hábitos e comportamentos morais, quer na vida individual, quer na vida social" (MILARÉ, 2013, p.147).

Existindo diversas tendências da ética ambiental, duas correntes fundamentais podem ser identificadas, contudo: a antropocêntrica, que defende a centralidade do homem em relação a outros seres; e a ecocêntrica, para a qual todos os seres devem ser considerados na filosofia moral (VALDÉS, 2004).

A perspectiva antropocêntrica restringe o âmbito da moralidade aos seres humanos e condiciona o comportamento perante a natureza às finalidades humanas:

Desta perspectiva, (...) [a função da ética] é aplicar uma teoria ética já existente a um novo tema, o ambiental (...). Nossas obrigações morais com o meio ambiente sempre são, desta perspectiva, derivadas de nossas obrigações morais para com os demais [homens] (VALDÉS, 2004, p. 8).

A corrente ecocêntrica preconiza, por sua vez, abranger a ética a todos os seres viventes (homens, animais e plantas indistintamente) até os sistemas que os suportam, devendo, inclusive, haver uma mudança radical nas nossas condutas com a natureza.

Aldo Leopold, filósofo e conservacionista norte-americano, um dos pioneiros nas teorias éticas em relação ao meio ambiente, tem influência fundamental na corrente ecocêntrica. Leopold fala de "Ética da Terra" no sentido de que considerações de ordem ética devem abranger o mundo biótico e abiótico: "a ética da terra simplesmente amplia os limites da comunidade para incluir solos, águas, plantas e animais, ou coletivamente: a terra” (LEOPOLD, 2004, p. 27).

A ética da terra na verdade, para o autor, representa "a existência de uma consciência ecológica". Quer dizer, questões éticas foram ampliadas de considerações sobre a relação entre os indivíduos, primeiro, e sobre os indivíduos e - Estado, em segundo, para preocupações em torno do meio que circunda o homem, representando mesmo uma necessidade ecológica. Afirma o autor: "a extensão da ética a este terceiro elemento do entorno humano é (...) tanto uma possibilidade evolutiva como uma necessidade ecológica" (LEOPOLD, 2004, p. 26).

Nessa ordem de ideias, o homem passa a ser apenas mais um membro da comunidade biótica existente na Terra, "de conquistador da Terra-comunidade para 
um simples membro e cidadão dela". A própria história humana é explicada de forma ecológica.

Que o homem é, de fato, tão só um membro de uma equipe biótica o mostra uma interpretação ecológica da história. Muitos sucessos históricos até agora explicados com base em ações humanas eram, na realidade, interações bióticas entre a gente e a terra. As características da terra determinam os fatos tão poderosamente como o fizeram as características dos homens que viviam nela (LEOPOLD, 2004, p. 28).

Portanto, os elementos da natureza possuem tanta importância quanto os seres humanos. Em consequência, a existência dos seres deve ser garantida com bases que vão além do cálculo econômico atribuído pelos homens, pois "a maioria dos membros que formam a comunidade da terra não têm valor econômico" (LEOPOLD, 2004, p. 32).

Sprigge (2004) acompanha o pensamento de Aldo Leopold e defende valores intrínsecos existentes nos elementos da natureza. Ou seja, existe um valor que independe da consciência humana sobre ela. Posiciona-se o autor dizendo:

\footnotetext{
Nós, os humanos capazes de valorar, bem podemos valorar coisas não humanas pelo que são em si mesmas, por seu próprio ser não humano, e não por seus efeitos sobre nós ou sobre outros seres sensíveis. Sem embargo, pessoalmente penso que 0 valor e o valor negativo são propriedades reais que certas coisas possuem (SPRIGGE, 2004, p. 206).
}

Arne Naess (2004) também entende que todos os seres têm o mesmo direito de viver e florescer assim como os humanos; do contrário, se restringirmos esse direito aos homens, efeitos nocivos seriam sentidos na qualidade de vida humana.

Naess advoga por uma ecologia profunda que se funda na ideia de valor intrínseco para todos os seres da Terra e no ideal de articulação mais profunda de nossa sensibilidade e mais espiritual com a natureza. Dentre suas plataformas estão o reconhecimento da riqueza e diversidade da vida como um valor em si mesmo à qual os humanos não têm direito de reduzir; a diminuição da população humana que possa permitir o florescimento da vida e a apreciação da qualidade de vida como uma mudança ideológica (NAESS, 2004).

No Brasil, dois juristas alinham-se ao ecocentrismo em ética ambiental. O primeiro, Édis Milaré, mantém posicionamento bem determinado: a ética ambiental está vinculada ao direito natural, este informando preceitos morais e normas jurídicas. Averba o autor: "nenhum ordenamento de costumes e de normas jurídicas pode contrariar a finalidade manifestada no significado natural e na destinação das 
coisas criadas, desde o menor dos ecossistemas até o ecossistema planetário em sua totalidade" (MILARÉ, 2013, p. 146).

Milaré aponta três aspectos éticos ambientais possíveis. No primeiro deles, numa perspectiva social, o meio ambiente é patrimônio público, de uso coletivo, como estabelecido na Lei 6.938/81. Não haveria razão para restringir de forma privada os recursos ambientais e naturais já que prevalece o sentido comunitário e coletivo do espaço social e recursos naturais. Consequentemente, afetando profundamente o direito de propriedade, agora o proprietário deve suportar uma hipoteca social, afirma Milaré:

os proprietários de recursos naturais e bens ambientais, seja a que título for, sob o ponto de vista ético não são senão meros gestores deste patrimônio, com a agravante de serem tanto mais cobráveis quanto mais manipularem e utilizarem tais recursos e bens, usufruindo deles em detrimento dos interesses coletivos de hoje e de amanhã (MILARÉ, 2013, p. 148).

A segunda perspectiva é a política. Aqui, o Estado é o gestor qualificado, pois legisla, executa, julga, vigia, defende e impõe sanções. Assim, numa boa moralidade administrativa evita que abusos antiecológicos de poder, discricionariedades e favorecimentos ilícitos gerem degradação ambiental.

A terceira e última é a perspectiva humanista onde predomina a ética da vida e para a qual a natureza, a vida humana e não humana possuem valores éticos intrínsecos em si mesmos (MILARÉ, 2013). Seria preciso, pois, um reordenamento dos valores culturais, inclusive os jurídicos e a legislação.

Por seu turno, José Renato Nalini, ex-presidente do Tribunal de Justiça do Estado de São Paulo, também defende o valor que a natureza tem por si mesma, independente de sua utilidade prática. Nalini chega mesmo a afirmar que a responsabilidade ética sobre a natureza deriva de exigências teológicas.

Para Nalini, o homem é inquilino indigesto do planeta Terra, agindo de forma ignorante, gerando degradações as mais diversas. Seriam necessários, então, padrões éticos globais que fomentassem uma solidariedade universal. "Esse mundo uno precisa de uma ética básica (...) para que a humanidade tenha chances de sobreviver, precisará de padrões éticos globais" (NALINI, 2015, p. 32). (Grifos no original).

Dessa forma, a ética ecológica nos libertaria da visão ingênua do antropocentrismo e nos levaria a um "sistema de responsabilidade prática entre 
todos" (NALINI, 2015, p. 34). Apenas uma ética ambiental seria capaz de reverter nosso comportamento e colocá-lo em harmonia com a natureza.

Nalini, entretanto, defende a cobrança de certos recursos naturais, como a água, por exemplo, justificando que assim reconheceríamos os recursos hídricos como bens econômicos e a utilizaríamos de forma racional e sustentável.

O intuito da cobrança pela utilização dos recursos hídricos é reconhecer a água como bem econômico e dar ao usuário uma indicação do seu real valor. Além disso, o propósito é incentivar o uso racional e sustentável da água e obter recursos financeiros para o financiamento dos programas e intervenções contemplados nos planos de recursos hídricos (NALINI, 2015, p. 88).

\section{1 ÉTICA, LEIS NATURAIS E NATUREZA DAS COISAS}

Os posicionamentos sobre a identidade ética com fatos naturais é posto sob análise e problematização por, dentre outros, Dale Jamieson (2010), Augustin Berque (1996) e Enrique Leff (2010), estes últimos mais alinhados com o antropocentrismo.

Jamieson, professor da Universidade de Nova lorque, argumenta, de início, que não é possível identificar propriedades morais com propriedades naturais, porquanto sempre cairíamos em questões abertas. Na linha de pensamento de Jamieson, dizer "gorilas-das-montanhas são valiosos" (é o exemplo dado pelo autor) abre um amplo espaço para debatermos quais propriedades ou estados do mundo tornam algo valioso ou não. "O problema não é apenas a dificuldade de juntar as informações relevantes, mas o amplo espaço para desentendimentos acerca de que informações deveríamos coletar" (JAMIESON, 2010, p. 86). Ou seja, a pergunta é o que deveríamos valorizar na natureza para que esta propriedade torne-se base para a ética ambiental.

Existe ainda, segundo Jamielson, a questão de definir o que na natureza possui valor intrínseco que possa fundamentar a edificação de um sistema ético e moral, pois a própria ideia de valor intrínseco possui diferentes conotações.

Primeiro, por um lado, o que é valor intrínseco é o de máximo valor, como o prazer, em contraste com o valor instrumental, como esquiar, que é favorável à produção de prazer. 
Por outro lado, em segundo lugar, valor intrínseco pode ser também o que importa na avaliação moral primária:

valor intrínseco é visto como o ingresso que admite algo à comunidade moral. Mais precisamente, ter valor intrínseco é suficiente para ser objeto de preocupação moral primária (...). Suponhamos que a senciência - a capacidade de prazer e dor - tenha valor intrínseco nesse sentido. Seguese que tudo o que for senciente será um membro da comunidade moral e seus interesses devem figurar em nossa tomada de decisão (JAMIESON, 2010, p. 115).

Em terceiro lugar, valor intrínseco chama-se "valor inerente" porque "o valor que de algo depende inteiramente do que é natural da coisa em si mesma" (JAMIESON, 2010, p. 116), menos o que possui propriedades relacionais, como o ecossistema ou a raridade de animais, pois eles pressupõem mais de um sujeito para existir. Sobre este ponto, exemplifica o autor:

o que torna uma certa gorila-das-montanhas (vamos chamá-la de Helen) rara é o fato de que existem muito poucos gorilas-das-montanhas. Se alguns gorilas-das-montanhas adicionais subitamente passassem a existir, então Helen não teria mais a propriedade de ser rara, assim, qualquer valor que ela pudesse ter não seria em virtude de sua raridade (JAMIESON, 2010, p. 117)

O último sentido de valor intrínseco é aquele no qual algo possui valor independente de alguém que o valorize: "por exemplo, um sistema ecológico que não envolva nenhum 'avaliador' poderia ser intrinsecamente valorizável nesse quarto sentido, embora possa não ser de valor intrínseco no terceiro sentido já que é necessariamente relacional" (JAMIESON, 2015, p. 118).

Augustin Berque (1996), por sua vez, argumenta pela impossibilidade de se erigir postulações éticas a partir da dicotomia homem-natureza operada pela ciência moderna.

Conforme apreciação de Berque (1996), a ciência moderna separa o ser do dever ser do mundo onde postulações éticas não estão vinculadas ao mundo objetivado composto de entes mecânicos, natureza-máquinas, na medida em que o que é não se confunde com o que deve ser. "Com efeito, não há em princípio campo algum para a ética - a qual supõe sujeitos humanos dotados de sensibilidade - se a fria razão coincide diretamente com as coisas. Conta apenas a eficácia desta coincidência" (BERQUE, 1996, p.32).

Para Enrique Leff (2010), em concordância com as posições anteriores, a tradição filosófica e científica "coisifica e objetiva o mundo" e coloca à margem "o ser 
significador da vida e das coisas, do real e da natureza", forjando "uma maneira de ver e pensar o mundo". Destarte, diz Leff,

\begin{abstract}
atrevo-me a afirmar que a crise ambiental não é senão a crise desse processo histórico que criou um pensamento que construiu o mundo através de teorias que, mais que refletir uma realidade fática, modelam o mundo, o constroem à sua imagem e semelhança. E a economia é o ápice dessa ficção da ciência moderna, ao gestar um princípio - o mercado - que transforma a natureza e o homem segundo os ditames de suas leis cegas e seus falsos equilíbrios; que constrói o homo economicus como a manifestação do grau mais elevando de racionalidade do ser, e que se confirma ajustando os comportamentos e desejos do homem aos desígnios da lei abstrata e totalitária do mercado (LEFF, 2010, p.25).
\end{abstract}

"A lei não está na origem e na essência das coisas", afirma Enrique Leff: "não existe uma lei natural que sirva de norma às ações dos agentes sociais para com a natureza" (2011, p. 349). Porém, legitimando os direitos ambientais numa pretensa universalidade ambiental válida em diferentes tempos e espaços, as normas conceituam e definem a natureza como uma mesma coisa, objetificada em prejuízo dos valores sociais. Os ordenamentos jurídicos elaborados dessa forma criam obstáculos para a defesa de direitos baseados em outras formas de apreensão da natureza, uma vez que, por fundar-se num paradigma moderno da dicotomia homem-natureza, outros conceitos e valores, outras racionalidades enfim "não encontram uma via clara de expressão de defesa" (LEFF, 2011, p. 353).

A questão ambiental, nesse sentido, reflete não só a necessidade de preservação da natureza, mas também de revalorização da diversidade étnica e cultural no "manejo produtivo da biodiversidade" (LEFF, 2011), onde as condições ecológicas são integradas com os potenciais tecnológicos e culturais de forma sustentável. No entanto, assevera Enrique Leff, “a sustentabilidade baseada em uma política da diversidade e da diferença implica fazer descer do seu pedestal o regime universal e dominante do mercado como medida de todas as coisas, como princípio organizador do mundo globalizado e do próprio sentido da existência humana" (LEFF, 2010, p. 26).

É preciso, pois, uma nova ética ambiental, uma nova racionalidade que faça emergir os diferentes sentidos éticos na apropriação da natureza de forma a evitar as disrupturas provocadas pela lógica econômica do mercado. "O grande desafio diante da crise ambiental não é economicizar a vida e a natureza, e sim pensar e construir outra economia" afirma Leff (2010, p.27): 
(...) para além da incomensurabilidade entre valores de mercado e valores morais, entre racionalidade econômica e racionalidade ecológica, a racionalidade ambiental rompe com o valor unitário da crematística do valor de mercado ao se abrir para uma política da diferença, entendida como uma pluralidade de racionalidade e identidades, a partir das quais se reconhece e se valoriza a natureza sob códigos culturais diversos. Nesse sentido, a racionalidade ambiental desconstrói o círculo fechado, unitário e universal do mercado e reabre os cursos e discursos civilizatórios em uma relação infinita entre cultura e natureza (LEFF, 2010, p. 26).

Segundo Leff, é precisamente na disputa para definir e fazer valer novos conceitos e valores que ultrapassem o paradigma moderno que se situam os movimentos sociais na luta por novos direitos ambientais "que legitime[m] e estabeleça[m] os procedimentos legais para sua defesa" (LEFF, 2011, p. 348).

Discutindo as diferenças entre as leis naturais e as leis éticas, Reale vai na mesma direção dizendo:

Há, pois, uma diferença fundamental entre esses dois grupos de leis, das
leis físicas e das leis éticas, de ordem causal umas, teleológicas as outras;
insancionáveis as primeiras, sancionáveis as segundas; leis não referidas
ao mundo dos valores, as físicas; leis essencialmente axiológicas, as que
regem o mundo do Direito ou da Moral. São dois mundos, que não se
repelem nem se excluem, mas, ao contrário, se completam, porque na base
do mundo da cultura está sempre o mundo da natureza (REALE, 2002, p.
253).

Para o jurista, o mundo natural não é desprezível para o Direito, sendo antes, na verdade, condição, mas não razão suficiente para sua gênese.

O fato natural, devemos assumir, pode ter e tem consequências no mundo do Direito, mas dele não necessariamente nasce uma lei de forma direta, como se das leis e relações naturais derivassem as leis humanas. Há de sobrevir uma valoração sobre o fato, tornando-o significativo em termos humanos e jurídicos.

Posturas éticas, afinal, devem erigir-se sobre a alteridade social reinante no mundo, negando fundamentos naturais supostamente universais.

Questões em torno da gênese das leis a partir da natureza, das leis naturais, são afins à discussão sobre a natureza das coisas. Quer dizer, existe nos fenômenos e fatos naturais algo inerente do qual derivam as leis jurídicas?

Montesquieu, ainda no século XVIII, definia a lei como "as relações necessárias que derivam da natureza das coisas" (MONTESQUIEU, 1960 apud REALE, 2000, p.24) ${ }^{10}$. A fórmula é repetida por Max Sorre em 1948 no livro Les Fondements de la Geographie Humaine nos seguintes termos: "a natureza das

\footnotetext{
${ }^{10}$ MONTESQUIEU, Do Espírito das Leis. São Paulo: Edições e Publicações Brasil Editora S-A, 1960.
} 
coisas, eis aqui o meio geográfico do qual estas regras são o reflexo" (SORRE, 1948, p. 143).

Se para Montesquieu a natureza das coisas explica tanto as leis físicas como as leis culturais (REALE, 2000), o mesmo não pode ser dito de Sorre sem cometer uma incorreção ao seu conceito de meio geográfico, o qual expressa mais do que o mundo físico-natural.

Consoante Norberto Bobbio, os juristas nunca examinaram profundamente o conceito de natureza das coisas. Segundo o autor, esta é uma noção puramente jusnaturalista e obedece à ideia de que as leis valem por si mesmas, independente dos atos volitivos do homem (BOBBIO, 2006, p. 176-7).

A natureza das coisas é uma noção que nasce, portanto, da exigência de garantir a objetividade da regras jurídicas. O problema é saber se existe efetivamente esta relação entre a natureza do fato e a regra. A nosso ver, a noção de natureza das coisas é negada por aquela que, em filosofia moral, é chamada de falácia naturalística, isto é, pela convicção ilusória de poder extrair da constatação de uma certa realidade (o que é um juízo de fato) uma regra de conduta (que implica num juízo de valor). O sofisma da doutrina da natureza das coisas, como do jusnaturalismo, é pretender extrair um juízo de valor de um juízo de fato (...). Na realidade, não é o fato em si que impõe a regra, mas o fim que se quer atingir; é o fim que faz apreciar de um certo modo os fatos (...). A natureza das coisas não pode, por si só, sugerir uma regra porque não pode sugerir um fim (...) (BOBBIO, 2006, p. 177-8).

Por fim, cabe resumir a discussão citando as palavras de Miguel Reale:

As normas jurídicas não são cópias de algo dado de antemão no processo social. O que existe são 'condicionantes naturais' e 'tendências constantes' que balizam e orientam o trabalho criador e constitutivo do legislador, primeiro, e do intérprete ou exegeta, depois (...). [Porém] é possível reconhecer-se que as normas jurídicas não podem ser elaboradas com desprezo de dados naturais que se impõe à consciência ética ou científica de todos. (REALE, 2000, p. 187).

\section{2 ÉTICA E ECÚMENO}

Os preceitos éticos ambientais também são discutidos no contexto do ecúmeno por Augustin Berque (1996). Deixa claro o autor, num posicionamento contrário ao fundamento natural da ética, que não se podem transferir preceitos éticos entre duas categorias de seres diferentes, ontologicamente falando. Quer 
dizer, os animais, as plantas, pertencem à sua própria categoria, diferente da categoria humana, esta marcada pela subjetividade. Nesse sentido, avaliando o holismo ecológico, diz Berque:

[o holismo ecológico] explica bem por que deve-se respeitar os ecossistemas, mas diante da questão de quem os deve respeitar, ele é seja mudo, seja incoerente; porque, se é o ser humano - mais do que, por exemplo, o gafanhoto ou o vírus da Aids - que deve ser tomado como responsável de respeitar o ecossistema, isso supõe a subjetividade do ser humano, é dizer que supõe-se que o ser humano pertence a uma categoria de ser - aquela do sujeito consciente e responsável - que não é nem aquela do gafanhoto nem aquela do vírus da sida (BERQUE, 1996, p. 69).

É nesse sentido que Augustin Berque critica a existência de um Direito da Natureza, porquanto não é possível, se considerarmos argumentos de ordem ética, colocar o homem na mesma categoria da natureza. Segundo Berque, a defesa de um Droit de la Nature recusa a considerar "um estatuto particular à subjetividade humana" (1996, p. 64).

Equipara-se, no fim, a natureza como um sujeito de direitos, sujeito encarnando de valores éticos e morais por pertencer à mesma categoria dos sujeitos humanos com sua subjetividade.

O que o Direito da Natureza considera, na verdade, é a categoria de um ser geral onde se dissolve a particularidade da subjetividade humana. "O holismo ecológico é obrigado a supor que todos os seres vivos pertencem à mesma categoria do ser; senão, ele não pode justificar sua posição fundamental, a saber, que o ser geral prevalece sobre o ser particular" (BERQUE, 1996, p. 69).

Segundo Berque, é preciso ver a relação do homem com a superfície terrestre enquanto tal para que se possa instituir a dimensão da ética ambiental. $\mathrm{Na}$ ótica do ecúmeno, a ética não surge da simples adição da ciência da natureza e da ciência do homem.

\footnotetext{
Não é partindo, de um lado, de uma reflexão sobre as condutas humanas (éticas), de outro, de uma ciência da natureza (ecologia) misturando suas especificidades respectivas e justapondo seus conceitos que se poderá fundar eticamente a relação da humanidade com a superfície terrestre, é examinando esta relação enquanto tal, e procurando como, nesta relação mesma, se institui a dimensão da ética (BERQUE, 1996, p. 79).
}

$\mathrm{Na}$ esteira das ideias anteriores, Augustin Berque diz que a ética ambiental deve ser pensada na perspectiva do ecúmeno, lembrando que o homem e a Terra se conjugam numa mesma realidade. 
O ecúmeno é a uma só vez a Terra e a humanidade; mas não é a Terra mais a humanidade, nem o inverso; é a Terra enquanto ela é habitada pela humanidade, e é também a humanidade enquanto habitada pela Terra. $\mathrm{O}$ ecúmeno é então uma realidade relativa, ou, dizendo mais exatamente, relacional; de onde nossa definição: o ecúmeno, é a relação da humanidade com a superfície terrestre (BERQUE, 1996, p. 78).

A ética ambiental, nesse sentido, se funda na noção de que "todos os fenômenos são uma expressão da subjetividade do ser ele mesmo" (BERQUE, 1996, p. 102). É porque os seres, na esfera do ecúmeno, incorporam a subjetividade humana que é possível edificar uma ética ambiental. "É esta estrutura que justifica, ontologicamente, que o ser humano deve respeitar os animais, as plantas, a vida, a todas as coisas inanimadas, porque os lugares dos seres de todos estes entes não são outro que os lugares dos seres humanos eles mesmos" (BERQUE, 1996, p. 138).

Berque argumenta que há uma questão de escala na problemática da ética. $\mathrm{Na}$ escala da natureza, diz o autor, não existe responsabilidade, direito ou virtude "que possamos conceber em termos éticos válidos para a escala da pessoa humana" (BERQUE, 1996, p. 131). Assim, considerar a escala do indivíduo como equivalente à escala da natureza é operar uma confusão escalar. 


\section{MEIO AMBIENTE NO BRASIL: NORMAS, POLÍTICAS E VALORES}

Embora preocupações em torno da relação do homem com o meio ambiente onde vive conheçam antigas formulações, uma ação mais ativa em prol da proteção ambiental contra atividades humanas potencialmente prejudiciais só tomaram corpo e ganharam força na década de 1970.

Em âmbito internacional, a proteção ao meio ambiente entrou na agenda internacional, sobretudo, com a Conferência de Estocolmo ocorrida em 1972, quando 113 países se reuniram para discutir os problemas ambientais comuns enfrentados.

No Brasil, é principalmente nos anos 80 e 90 que a defesa do meio ambiente ganha força, com a edição de leis, a criação de instituições e o surgimento de associações da sociedade civil de proteção ambiental.

Anteriormente, contudo, discursos em defesa da riqueza e diversidade da natureza no país, bem como legislações eminentemente protetivas da fauna e flora nacionais, testemunham a existência de inquietações em torno da proteção ambiental desde pelo menos o período colonial.

Durante o desenvolvimento histórico do país, tais preocupações se avolumaram, resultando num aumento das políticas estatais e atuações da sociedade civil, cada vez mais incisivas, em prol da preservação do ambiente.

A defesa do meio ambiente no Brasil, entretanto, atendeu a diferentes valores e interesses predominantes em cada período, ora rompendo com especificações do passado, ora mantendo determinações pretéritas sob novo equilíbrio de forças.

Hoje, novas éticas ambientais são incorporadas na história de proteção ambiental do país, acrescentando novos valores na defesa nacional do meio ambiente.

\subsection{O PERÍODO COLONIAL}

No Brasil, reflexões e normas sobre o meio ambiente existem desde o período colonial. Os termos empregados, o objeto para o qual se voltava o olhar, a finalidade e os valores que informavam as normas e posições, porém, modificaram-se no decorrer da história do país, fruto de novos paradigmas e preocupações da sociedade com o meio ambiente. 
No contexto do Brasil colônia, predominam os interesses econômicos na ocupação do espaço, havendo pouco terreno para políticas restritivas de proteção ambiental. De fato, as atividades de ocupação e exploração do território visaram, precipuamente, extrair lucros para a metrópole, sendo a organização agrária, a mineração e o próprio extrativismo praticado na bacia amazônica algumas das atividades destinadas a saciar a ganância da coroa portuguesa (PRADO JUNIOR, 2008) e nada inibidas, na prática, em nome da proteção ambiental.

Existe, neste período, contudo, registros sobre o meio ambiente do Brasil colonial encontrados nos escritos dos viajantes, cronistas e naturalistas que primeiro visitaram a colônia e que, sob diferentes propósitos, registraram as visões predominantes na época sobre a natureza.

Segundo José Augusto de Pádua (1987), estes viajantes conjugavam dois olhares sobre o meio ambiente: um primeiro, derivado da cultura renascentista que enxergava na natureza a imagem do Éden divino; o segundo enxergava a natureza em função de interesses mercantilistas e comerciais.

Assim, diz Pádua: "algumas das primeiras descrições da natureza brasileira e seus primitivos habitantes assumiram a imagem do reencontro com o próprio Éden", encontrando-se aí, "alusões à essência edênica da natureza brasileira, expressas na excelência do seu clima, na saúde e longevidade dos seus habitantes" (PÁDUA, 1987, p. 16-7).

Por outro lado, e de forma não antagônica, pois presente às vezes no mesmo autor, "o Brasil era um imenso 'pau-brasil', uma rica natureza a ser usada e explorada sem nenhuma preocupação além do ganho imediato" (PÁDUA, 1987, p. 18-9).

A visão econômica da natureza, entretanto, predominou no contexto de descobrimento e exploração colonial do Brasil. Com efeito, a visão portuguesa de exploração econômica da natureza decorre da própria lógica que regia a empresa colonial e vai permanecer durante toda a história do país. Quer dizer, o ânimo econômico dos portugueses de conquista do espaço e apropriação dos recursos naturais vai marcar a formação colonial brasileira e se estender até o período republicano.

Denunciando tais interesses econômicos, Antônio Carlos Robert Moraes assevera: "uma ótica dilapidadora comanda o processo de instalação do colonizador, 
a qual se expressa num padrão extensivo (do ponto de vista do espaço) e intensivo (do ponto de vista dos recursos naturais) de uso do solo" (MORAES, 2005, p. 13).

De fato, consoante Pádua (1987), existe uma permanência, ao longo da política ecológica nacional, de uma visão exploratória da natureza, se bem que em conjunto, por outro lado, com o discurso louvatório em relação à mesma, esta servindo muitas vezes para escamotear a realidade da devastação existente. Diz o autor:

temos a respeito da questão da natureza no Brasil uma tradição de dois polos esquizofrenicamente divorciados: uma celebração puramente retórica de um lado, e uma realidade de devastação impiedosa do outro. É verdade que esse divórcio é em grande parte aparente, na medida em que a retórica serve para obscurecer a prática, desviando o olhar de uma realidade que violenta tudo o que é idealizado na teoria (PÁDUA, 1987, p. 20).

Tal situação, continua Pádua (1987), só foi por vezes rompida por pensadores críticos que buscavam outro projeto para o país que não aquele da exploração predatória feito pela metrópole. Frei Vicente de Salvador, Ambrósio Fernandes Brandão ou José Bonifácio são exemplos de pensadores que, cada um a sua maneira, condenavam o tipo de colonização feita pelos portugueses ao mesmo tempo em que propunham uma alternativa de desenvolvimento para a colônia.

Contudo, tal visão crítica não floresceu na colônia, predominando ainda os objetivos dilapidadores mercantilistas da metrópole.

\begin{abstract}
Infelizmente, esse tipo de análise mais crítica, que se preocupa em denunciar a relação predatória e displicente com a terra e a mentalidade exploratória que impedia a constituição de uma vida social mais orgânica no Brasil, foi pouco cultivado no período colonial. Em termos de práticas administrativas concretas a omissão era igualmente notável, e só encontramos algumas medidas mais práticas contra a destruição das matas, por exemplo, no final do século XVIII - e mesmo assim em função das necessidades de construção naval da marinha portuguesa (PÁDUA, 1987, p. 21).
\end{abstract}

Para Pádua, as medidas mais práticas da administração portuguesa davamse contra a destruição das matas e, de fato, a proteção de árvores que servissem à construção naval era a tônica da preocupação da administração colonial.

Com efeito, se olharmos para a legislação da época, veremos que a salvaguarda de árvores, matas e florestas frequentemente são citadas nos diplomas legais.

Segundo Wainer, sempre houve preocupação da coroa portuguesa com a proteção das riquezas florestais, preocupação expressa já nas Ordenações 
Afonsinas que vigoraram na colônia quando do descobrimento do Brasil. Mas outras normas para além da proteção florestal são também encontradas na legislação colonial, principalmente nas Ordenações Manuelinas e Filipinas, levando a autora a afirmar que "a legislação ambiental portuguesa era extremamente evoluída" (WAINER, 1999, p. 5).

As Ordenações Manuelinas, por exemplo, que vigoraram no Brasil colônia até o início do século XVII, proibiam o uso de instrumentos que pudessem causar dor e sofrimento na morte de animais (Título LXXXIII), colocava as abelhas sob proteção especial (Título XCVII) e introduziam o conceito de zoneamento ambiental "ao vedar a caça em determinados lugares" (WAINER, 1999).

As Ordenações Filipinas, por sua vez, expedidas a 11 de janeiro de 1603, mantinha certa proibição de corte de árvores frutíferas (Título LXXV), dava proteção às abelhas e ao gado (Título LXXVIII) e mantinha a proibição de uso de instrumentos que causassem dor ou sofrimento na caça de perdizes, lebres e coelhos (Título LXXXVIII). Ademais, o Código Filipino trazia o conceito de poluição das águas (Título LXXXVIII, $\S 7^{\circ}$ ), pois "expressamente proibia a qualquer pessoa jogar material que pudesse matar os peixes" (WAINER, 1999, p. 19).

$\mathrm{Na}$ mesma linha de Pádua, entretanto, Ann Helen Wainer concorda que as normas descritas eram pouco efetivas. "Não se tem evidência da aplicação concreta dessa legislação ambiental que aqui analogamente deveria ser cumprida", assevera (WAINER, 1999, p. 19).

As causas do descumprimento da legislação encontram-se talvez na sobreposição dos interesses particulares sobre os interesses públicos, opina Édis Milaré, pois no Brasil colônia havia um descompasso entre "a estrutura formal (leis e Administração Pública) e estrutura real (a mentalidade e as práticas correntes, o dia a dia da vida colonial)" (MILARÉ, 2013, p. 235).

A opinião de Milaré é corroborada pela de Wainer na medida em que a autora também concorda que faltava certo civismo tanto da administração quanto da população.

$\mathrm{Na}$ verdade pouco valiam as leis que visavam à conservação das florestas, se não existia uma conscientização coletiva, no sentido de respeitá-las, fazendo com que fossem cumpridas. O problema era bilateral, pois está tanto na falta de civismo do corpo administrativo, quanto na falta de civilidade por parte da população (WAINER, 1999, p. 47). 
Wainer concorda igualmente, por outro lado, que os interesses de preservação da natureza atendiam mais a cálculos econômicos do que propriamente um ideal ecológico. Analisando as posições, por exemplo, do Ouvidor e Conservador das matas da Comarca de Ilhéus, Balthazar da Silva Lisboa, que recorrera a fazendeiros solicitando prevenção contra os crimes florestais, considera que:

A princípio, sem analisar os aspectos históricos e econômicos da época, parecem essas atitudes augurar um novo pensamento e um ideal ecológico. Na realidade, esses posicionamentos continham interesses puramente econômicos; pois a escassez das madeiras significaria a acumulação de grandes prejuízos (WAINER, 1999, p. 47).

\subsection{O BRASIL IMPERIAL}

A independência do Brasil em 1822 fomentou novas ideias e embates políticos no país, porém a base econômica continuava a ser a exploração agrícola. $O$ café despontava na pauta de exportações, sendo produzido de forma crescente na região Centro-Sul; no Nordeste, a produção açucareira, embora em declínio, continuava tendo importância econômica na região e na pauta de exportações nacionais, sendo superada pelo algodão somente na segunda metade do século XIX; na Bacia Amazônica, a exploração da borracha ganhava impulso com os novos usos industriais do material (FAUSTO, 2003).

Politicamente, a vinda da família real em 1808 e, posteriormente, D. Pedro I assumindo como imperador do Brasil, forçou a definição da antiga colônia como país nação. Todo o esforço da elite política dirigiu-se para a construção de uma identidade nacional que desse condições para a manutenção do país enquanto povo e território. Com esse propósito, forjou-se, então, um discurso oficial em termos de história, território e culturas comuns.

Neste contexto político-econômico, a natureza foi revalorizada, ora servindo para a exaltação das grandezas do novo país independente, ora sendo apropriada como recurso a ser explorado. A exuberância e diversidade da natureza no Brasil serviram a este duplo propósito.

A natureza ganha, nesse período, maior atenção dentro do discurso político e econômico que se desenhava no Brasil: por um lado, ela representava o que havia de verdadeiramente nacional uma vez que o escravo africano, o índio silvícola e o 
português não poderiam ser considerados nacionais, brasileiros; por outro, a natureza englobava um vasto território a ser explorado, de onde os ganhos econômicos seriam retirados.

Em relação a este último aspecto, não houve verdadeiro rompimento com as determinações coloniais depois da independência do Brasil. Continuava-se explorando de maneira intensiva a natureza, dilapidando o patrimônio natural brasileiro, mesmo que ainda sob um discurso da grandeza de seu meio ambiente (MORAES, 2005).

Isto porque o grande mote legitimador do Estado brasileiro, consoante Moraes (2005), sempre foi a conquista do espaço e a construção de um país. Apropriar-se economicamente da natureza e transformá-la segundo os padrões civilizados de cada período, dando forma ao Brasil, é o que justifica a existência de um Estado cuja presença de uma nação aos moldes europeus é ausente.

Nesse quadro, a natureza brasileira é vista como pura riqueza a ser apropriada, e o espaço e os recursos naturais são tomados como inesgotáveis. Daí a ideia do país celeiro de riquezas, o 'gigante deitado em berço esplêndido', em certo momento 'a vaquinha-de-leite de Portugal'.

Uma ótica espoliativa domina a relação da sociedade com o meio no Brasil, a qual se expressa com clareza no ritmo e na forma como avançam as 'frentes pioneiras' na história do país, deixando ambientes degradados em sua retaguarda (MORAES, 2008, p. 139).

Dada as circunstâncias históricas, houve a necessidade de produzir conhecimento mais detalhado da diversidade natural presente no território, preenchendo de conteúdo afirmações genéricas sobre a riqueza do país e fornecendo material para exploração política e econômica (PÁDUA, 2009). Nesse sentido, José Augusto Pádua lembra os discursos proferidos por José Bonifácio, ainda em 1819, destacando a necessidade de conhecimento da natureza brasileira e suas riquezas, principal capital político do Império.

A urgência desse conhecimento, na visão de Bonifácio, deriva do fato de a natureza constituir o recurso político mais essencial do Brasil. É significativo que no discurso de 1819 (...) quase não se faça referência às possíveis virtudes da sociedade brasileira. A ignorância, o atraso tecnológico, a violência e, principalmente, o trabalho escravo que a caracterizavam não eram fonte de grandes esperanças. A utopia de construir um poderoso império na América portuguesa assentava-se quase que exclusivamente na posição e riqueza do território (PÁDUA, 2009, p. 328). 
São desta época, destarte, que datam as primeiras comissões e institutos voltados ao levantamento estatístico e geográfico do território nacional, instrumentalizando o Estado com um aparato geográfico oficial (UGEDA, 2017).

É neste período que são criadas a Commissão de Estatística geographica e natural, política e civil (sic) (decreto de 25 de novembro de 1829) e o Instituto Histórico Geográfico Brasileiro (1838). São incentivados, também, a expansão da litografia de mapas e carta do território nacional e, a partir da década de 1840, começam os encaminhamentos para os censos a nível nacional (o último censo foi realizado em 1872, durante o reinado de D. Pedro II) (UGEDA, 2017).

Assevera Luiz Ugeda sobre a instrumentalização da Geografia de Estado:

\begin{abstract}
Assim, o Império promoveu a Geografia de Estado em diversas frentes, mas de forma desequilibrada: havia uma busca por instrumentalizar, por meio de órgãos, um sistema de representação do espaço nacional, mas de maneira precária, sem uma noção de sistemas e com uma concepção de Geografia descritiva e não reflexiva. Os mapas produzidos eram temáticos e pouco permitiam uma análise conjunta entre si. O Censo de 1872 foi um grande marco da política geográfica, mas não teve continuidade, situação que fazia o conhecimento do país se deteriorar rapidamente, haja vista o ambiente de alta mutação econômica, demográfica e social (UGEDA, 2017, p. 82).
\end{abstract}

Data deste período, por fim, a Lei 601 de 18 de setembro de 1850, primeira lei que dispõe sobre as terras devolutas do Império, que dava atenção aos desmatamentos e incêndios criminosos, obrigando os posseiros das terras devolutas a despejo e perda de benfeitorias.

\title{
4.3 O PERÍODO REPUBLICANO: 1889-1930
}

Com a queda da monarquia em 1889, o Brasil adentra o período republicano de sua história, com transformações e rearranjos de ordem política, econômica e cultural.

A preocupação imediata era organizar a forma de Estado e a forma e sistema de governo. Promulgada a Carta Constitucional de 1891, o Brasil tornou-se uma república federativa, garantindo certas autonomias aos Estados (os Estados poderiam tomar empréstimos no exterior e taxar as mercadorias estaduais de exportação) de forma a não comprometer a integridade do território nacional. Foi adotado, também, o sistema presidencialista de governo, com voto direto e universal (excluídos analfabetos, praças militares e mendigos) e separados o poder da lgreja do poder estatal. 
O destino político do país, contudo, era controlado por pequenos grupos oligárquicos estaduais que monopolizaram o Estado nacional na defesa de seus interesses regionais (FAUSTO, 2003).

Economicamente, o país continuava a ser um país essencialmente agrícola, não obstante a crescente importância que a produção industrial adquiria, principalmente no Centro-Sul. A produção agrária, por outro lado, também se diversificou para atender ao mercado interno, este alavancado pelo processo de urbanização que o país conhecia.

Noutra seara, o desejo de tornar o Brasil um país moderno e civilizado, aos moldes das civilizações europeias, permaneceu no ideário dos intelectuais e da elite política do país. Neste ambiente, tomou força no Brasil as ideias provenientes do higienismo.

Nascido na Europa do século XIX, o higienismo traduzia a preocupação dos governos com a saúde dos habitantes da cidade. Em meio a cortiços e aglomerações de toda ordem que se espalhavam pelo espaço urbano, era preciso manter a ventilação, insolação e circulação das águas de forma a condicionar um ambiente salubre.

Em termos ambientais, intervenções para sanar espaços construídos ou naturais foram levadas a cabo em nome dos ideais higienistas. Projetavam-se ações que almejavam manter ou transformar grandes espaços urbanos em ambientes salubres e adequados para uso e habitar humanos. Nesse momento, o Estado preocupava-se em sanar as doenças que assolavam o interior e fomentar um processo civilizatório no país.

Os ideais higienistas espalharam-se por todo Brasil, promovendo intervenções no espaço urbano de cidades como Rio de Janeiro, Santos, Poços de Caldas ou alcançando lugares tão distantes da capital como Pelotas, no Rio Grande do Sul ou Recife, em Pernambuco (SOARES, 2000).

No Rio de Janeiro, o prefeito Pereira Passos levava a cabo as transformações urbanísticas da então capital federal com objetivo de torná-la moderna e europeizada: Passos removeu cortiços do centro da cidade, aterrou espaços brejosos e rasgou a cidade com a abertura de túneis e avenidas.

As transformações higiênicas e saneamento dos espaços levou, outrossim, à preservação de elementos ambientais que garantissem os objetivos desejados. 
Em Minas Gerais, a cidade de Poços de Caldas experimentava a mesma sorte nos espaços: a atuação de médicos higienistas (o nome do doutor Pedro Sanches de Lemos deve ser lembrado) acabou garantindo a manutenção da limpeza das fontes e a preservação de certas matas que corriam risco de degradação (SOUZA, 2012).

A própria legislação municipal refletia o contexto higienista. A Lei n 157 de 30 de setembro de 1921 autorizava a prefeitura a organizar tipos de habitações higiênicas nos moldes das modernas cidades europeias. Dizia a lei:

art. $1^{\circ}$ - Fica a prefeitura municipal autorizada a mandar organizar tipos de planos de habitações com mais propriedade higiênica e mais apropriado aspecto arquitetônico, para melhorar a construção da cidade, podendo cedê-los por cópias, aos interessados, mediante pagamento de pequena taxa, sem permitir, no entanto, a sua repetição exata em prédios próximos. (...)

art. $3^{\circ}-$ no regulamento a se organizar serão seguidas as regras gerais de arquitetura e construção comumente observados nas Cidades Modernas, tendo-se, contudo, em vista as condições do meio.

A mata da Serra de São Domingos, por exemplo, no extremo norte do município, foi preservada em grande medida em função da concepção médica e higiênica que dominava a construção da estância balneária de Poços de Caldas, não obstante algum incipiente intuito preservacionista ambiental que possa ter existido. Escrevia o Dr. Pedro Sanches em 1904: "esta mata quase desapareceu hoje, por amor do machado e do fogo, apesar de meus veementes protestos. Nunca se viu maior desprezo pelos conselhos da higiene" (LEMOS, 1904, p. 153).

Muitas destas preocupações com saúde e higiene tiveram como consequência a edição de normas de cunho eminentemente ambiental de fato, como registrado em diversos Códigos de Posturas Municipais ou leis estaduais.

Elvino Antônio Lopes Rivelli menciona o Código Sanitário do Estado de São Paulo, instituído pelo Decreto n 233 de 02 de março de 1894, cujos artigos regulamentavam o lançamento de esgoto nos rios (estes deveriam ser antes purificados, lançados no meio do rio e a jusante da população) (RIVELLI, 2005).

Iniciativas de cunho mais propriamente ambiental foram tomadas, entretanto, como ilustra a criação da reserva florestal do Acre em 1911 (decreto no 8.843 de 26 de junho de 1911) e a fundação do Serviço Florestal do Brasil em 1921.

Em nível federal, o Código Civil de 1916 trouxe alguns artigos atinentes à proteção à natureza, da qual se pode citar: o artigo 554, que impedia que o mau uso da propriedade vizinha prejudicasse a segurança, o sossego e a saúde dos 
moradores; e o artigo 584 que proibia construções capazes de poluir, ou inutilizar, para o uso ordinário a água de poços ou fonte alheia, a elas preexistentes (WAINER, 1999; MILARÉ, 2013).

À promulgação do Código Civil de 1916, seguiu-se a edição de uma série de diplomas legais que regulamentavam a exploração das florestas, das águas, o aproveitamento das reservas minerais, a proteção ao patrimônio nacional e outros.

\subsection{O PERÍODO REPUBLICANO A PARTIR DE 1930 E O REGIME MILITAR}

A ascensão de Getúlio Vargas em 1930 significou a centralização do poder no âmbito federal, com a perda de autonomia dos estados e a nomeação de interventores pelo presidente. Em meio a esforços estatais voltados à industrialização do país, sustentada por uma política de substituição de importações e instalação de um parque industrial de base, o acesso, uso, controle e proteção dos recursos naturais foi regulamentado por uma série de diplomas legislativos setoriais.

A própria Constituição Federal de 1934 passa a conter alguns dispositivos de cunho ambiental, como o artigo 10, inciso III, por exemplo, que estabelecia a competência concorrente da União e dos Estados para proteger as belezas naturais e os monumentos de valor histórico ou artístico.

Os anos de 1930 também são referência para Luís Henrique Cunha e Maria Célia Nunes Coelho (2012) proporem uma primeira fase das políticas públicas voltadas ao meio ambiente. Consideram os autores que o período compreendido entre 1930 a 1971 conformam, de fato, uma primeira fase das políticas nacionais ambientais caracterizadas pela construção de uma base regulatória nacional de uso dos recursos naturais. Afirmam:

\footnotetext{
Nesse primeiro período das políticas ambientais no Brasil, privilegiou-se uma abordagem nacional do problema ambiental e apenas secundariamente ações com caráter regional. As ações públicas incidiram basicamente nas regiões Sul e Sudeste, onde os processos de industrialização e urbanização estavam mais avançados (CUNHA e COELHO, 2012, p. 47).
}

Nesse momento, os autores mencionam, então, a criação do Parque Nacional de Itatiaia, no Rio de Janeiro, e a Floresta Nacional de Caxuanã, na Amazônia, ambos influenciados pela criação de parques nacionais nos Estados Unidos. É nesse período também que surge a Fundação Brasileira para a Conservação da 
Natureza (FBCN), entidade filiada à União Internacional para a Conservação da Natureza, e é criado o Instituto Brasileiro de Desenvolvimento Florestal (IBDF) (CUNHA e COELHO, 2012).

É ainda nessa primeira fase que o conceito de poluição começa a ser aprimorado na legislação: primeiro com o próprio Código das Águas de 1934, nos artigos 98 e 109 e, posteriormente, com os Decreto-lei no 50.877 de 1961, № 303 de 1967 e no 221 também de 1967, respectivamente (WAINER, 1999).

Dentre a legislação editada no período pode-se citar:

- $\quad$ Decreto 23.793 de 23 de janeiro de 1934 (institui o Código Florestal);

- $\quad$ Decreto 24.643 de 10 de julho de 1934 (institui o Código das Águas);

- Decreto-lei no 25 de 30 de novembro de 1937 (organiza a proteção do patrimônio histórico e artístico nacional);

- $\quad$ Decreto-lei no 794 de 19 de outubro de 1938 (institui o Código de Pesca);

- $\quad$ Decreto-lei no 1.985 de 29 de janeiro de 1940 (institui o Código de Minas);

- $\quad$ Lei 4.771 de 15 de setembro de 1965 (institui o novo Código Florestal);

- $\quad$ Lei 5.197 de 03 de janeiro de 1967 (estabelece a proteção à fauna)

Paralelamente a esta profusão de diplomas legais, o Estado se estrutura melhor para promover o adequado ordenamento das atividades econômicas no território e nas regiões respectivas (UGEDA, 2017). Desse modo, foram criados: o Departamento Nacional de Produção Mineral (Decreto no 24.648/1934), voltado à regulação das atividades geológicas e mineralógicas no país; o Conselho Nacional de Petróleo (Decreto-lei no 395/1938); e o Instituto Brasileiro de Geografia e Estatística (Decreto-lei no 218/1938), responsável pelos dados demográficos, econômicos e sociais do país.

A tônica destas legislações, contudo, continua a ser o caráter econômico dos recursos naturais, reproduzindo a velha visão mercantilista do período colonial (MORAES, 2008; MILARÉ, 2013). Se o meio ambiente ainda era protegido por normas pontuais e na esteira de valores emergentes (saúde e higiene), a apropriação lucrativa da natureza ditava ainda grande parte da ação pública.

A propósito, Paulo de Bessa Antunes afirma: "de alguma forma, a Constituição Federal de 1934 estimulou o desenvolvimento de uma legislação 
infraconstitucional que se preocupou com a proteção do meio ambiente, dentro de uma abordagem de conservação dos recursos econômicos" (ANTUNES, 2013, p. 65) (Grifos nossos).

Por outro lado, a natureza continuava contendo as possibilidades para a construção da riqueza da nação brasileira: era na natureza existente no território nacional que repousava o progresso econômico e social do país. Em discurso proferido em 1937, em meio ao processo de ocupação do interior do país, Getúlio Vargas afirmava:

Retomando a trilha dos pioneiros que plantaram no coração do Continente em vigorosa e épica arrancada, os marcos das fronteiras territoriais, precisamos de novo suprimir obstáculos, encurtar distâncias, abrir caminho e estender fronteiras econômicas, consolidando, definitivamente, os alicerces da nação (...). E lá teremos de ir buscar: - dos vales férteis e vastos, o produto das culturas variadas e fartas; das entranhas da terra, o metal, com que forjar os instrumentos da nossa defesa e do nosso progresso industrial (VARGAS, citado por UGEDA, 2017, p. 136).

Uma segunda fase, periodizada por Cunha e Coelho (2012), estende-se de 1972 a 1987. Sob a influência das discussões internacionais, nomeadamente do relatório do Clube de Roma, das discussões realizadas durante a Conferência de Estocolmo de 1972 e influenciada também pela criação de agências ambientais na Europa e América do Norte, a proteção ao meio ambiente ganho novo patamar.

A Declaração de Estocolmo nasceu por iniciativa da Suécia, país que propôs à ONU uma conferência internacional para tratar dos problemas ambientais mais importantes em escala mundial.

Reunindo 113 países, 250 organizações não governamentais e organismos da ONU, a Conferência das Nações Unidas sobre o Meio Ambiente Humano foi realizada em 1972 e resultou na criação do Programa das Nações Unidas para o Meio Ambiente e na declaração de 26 princípios. No geral, tais princípios adotaram uma perspectiva mais integrativa para o meio ambiente.

Iniciando uma ruptura com a proteção reflexa e parcelada que existia, novas ideias e valores relativos ao meio ambiente consolidam-se em âmbito internacional, desdobrando-se em políticas ambientais específicas no Brasil.

Consoante Cunha e Coelho (2012), tal período é marcado, no âmbito do Estado brasileiro, pela criação de um arcabouço institucional destinado a lidar com os problemas ambientais. Viola e Leis mencionam que em 1970 havia 12 agências ambientais nacionais enquanto em 1990 já eram mais de 140 em nível federal, estadual e municipal (VIOLA E LEIS, 1995, p. 75). 
É na década de 70, igualmente, que o movimento ambientalista no Brasil ganha corpo. Quer dizer, se antes os protestos contra a destruição da natureza não encontravam ecos no âmbito político e social, como mostrou Pádua (1987) a respeito das ideias de José Bonifácio ou Joaquim Nabuco, o ambiente internacional e o retorno, para o Brasil, de exilados políticos engajados com as questões ambientais conformou a conjuntura necessária para que as problemáticas com relação ao meio ambiente entrassem na pauta de discussões.

De fato, os debates realizados por ocasião da Conferência de Estocolmo de 1972 e a respectiva Declaração do Meio Ambiente com seus 26 princípios, mais do que apenas criarem condicionantes para a atuação do Estado, abriram caminho para que a preservação do meio ambiente fosse discutida politicamente e se desdobrasse em diplomas legislativos (SILVA, 2009; ANTUNES, 2013).

Ademais, o país conheceu, na década de 1970, o encontro de intelectuais exilados, que viveram a experiência dos movimentos ecológicos na Europa - como Fernando Gabeira - com ativistas que já lutavam no Brasil para a proteção ambiental, podendo-se mencionar igualmente a atuação do engenheiro agrônomo José Lutzenberger (VIOLA, 1987; GONÇALVES, 2010).

Dentro deste contexto, deve-se mencionar a fundação, por Lutzenberger, da Associação Gaúcha de Proteção ao Ambiente Natural (AGAPAN), "primeira associação ecologista a surgir no Brasil e na América Latina", segundo Viola (1987, p. 87), embora existisse já, desde 1958, a Fundação Brasileira para a Conservação da Natureza.

É no finalzinho deste segundo período que Juliana Santilli (2005) diz nascer o socioambientalismo brasileiro, movimento criado a partir da união dos movimentos sociais com o movimento ambientalista.

O socioambientalismo só vai se consolidar, entretanto, segundo Santilli, com a Constituição Federal de 1988 e com a Conferência das Nações Unidas sobre Meio Ambiente e Desenvolvimento - a Rio 92 (SANTILLI, 2005).

O socioambientalismo brasileiro - tal como o reconhecemos e identificamos - nasceu na segunda metade dos anos 80 , a partir de articulações políticas entre os movimentos sociais e o movimento ambientalista. $O$ surgimento do socioambientalismo pode ser identificado com o processo histórico de redemocratização do país, iniciado com o fim do regime militar, em 1984, e consolidado com a promulgação da nova Constituição, em 1988, e a realização de eleições presidenciais diretas, em 1989. Fortaleceu-se - como o ambientalismo em geral - nos anos 90, principalmente depois da realização da Conferência das Nações Unidas sobre Meio Ambiente e 
Desenvolvimento, no Rio de Janeiro, em 1992 (Eco-92), quando os conceitos socioambientais passaram claramente a influenciar a edição de normas legais (SANTILLI, 2005, p. 31).

Consoante Santilli, o socioambientalismo é caracterizado pela defesa da esfera social na política ambiental brasileira, até então marcada por uma visão conservacionista. Conforme a autora, "verifica-se nas leis ambientais editadas durante esse período histórico uma orientação conservacionista, voltada para a proteção de ecossistemas e espécies, mas sem uma dimensão social claramente incorporada" (SANTILLI, 2005, p. 29).

No que concerne a instituições estatais, é criada, em 1973, a Secretaria Especial do Meio Ambiente (SEMA) (Decreto № 73.030), voltada para a conservação do meio ambiente e para o uso racional dos recursos naturais, e, em 1985, o Ministério do Desenvolvimento, Urbanização e Meio Ambiente.

Pertence igualmente a esse período a promulgação da Lei 6.938 de 31 de agosto de 1981 que dispõe sobre a Política Nacional do Meio Ambiente. A lei define o conceito normativo de meio ambiente, até então usado de forma indistinta com o termo natureza. No seu artigo 6으, ademais, a Lei 6.938 institui o Sistema Nacional do Meio Ambiente (SISNAMA) e o Conselho Nacional do Meio Ambiente (CONAMA). Enquanto o primeiro organiza as instituições governamentais responsáveis pela proteção e melhoria da qualidade ambiental, o segundo estabelece normas e critérios que assegurem a proteção ambiental.

Em 1986, o CONAMA edita a Resolução 001 de 23 de janeiro instituindo a obrigatoriedade do Estudo de Impacto ambiental (EIA) e do Relatório de Impacto Ambiental (RIMA), impondo a uma série de atividades o seu cumprimento (artigo $2^{\mathrm{a}}$ ).

Esta segunda fase é caracterizada, também, por um crescente aprimoramento do conceito de poluição (Decreto no 73.030 de 1973; Decreto-lei ํo 1.413 de 1975), culminando com a definição trazida pela Lei 6.938 de $1981 \mathrm{em} \mathrm{seu}$ artigo 3ㅜㅗ. inciso III (ver tabela 5) (WAINER, 1999).

A avaliação que se faz de tais leis e instituições, contudo, é que sua criação foi, antes, uma resposta às pressões internacionais do que uma genuína preocupação ambiental no seio do estado nacional. Ademais, o governo, sob o comando dos militares, possuía um projeto de desenvolvimento para o país que entrava em contradição com as exigências de preservação do meio ambiente, sendo aquele preferido a este. Tem-se assim, que as instituições de cunho ambiental 
criadas no período analisado visavam acima de tudo atender às exigências internacionais necessárias para a captação de recursos e empréstimos.

Para Viola (1987), o discurso durante o período militar e mesmo depois, com a redemocratização, sempre foi do crescimento econômico e não da preservação ambiental.

Esta é a mesma avaliação feita por Carlos Walter Porto Gonçalves. Diz o autor:

A pressão da preocupação ambientalista que cresce a nível
internacional obriga as instituições financeiras públicas e privadas a
colocarem exigências para a realização de investimentos aqui (...).
Assim, antes que se houvesse enraizado no país um movimento
ecológico, o Estado criou diversas instituições para gerir o meio
ambiente, a fim de que os ansiados investimentos pudessem aqui
aportar (...) a lógica destas instituições é determinada pela política
global de atração de investimentos e não pelo valor intrínseco da
questão ambiental (GONÇALVES, 2010, p. 15).

A SEMA, por exemplo, foi criada, nas palavras de Viola:

com o único objetivo de cumprir exigências de alguns organismos internacionais, que exigiam a existência formal deste tipo de órgão junto com relatórios de impacto ambiental, para a aprovação de empréstimos destinados a grandes obras públicas. Durante todo o regime militar, a SEMA foi uma agência marginal do Ministério do Interior (VIOLA, 1987, p. 84).

Mesmo Édis Milaré, que ressalta a criação da SEMA e do Plano Nacional de Desenvolvimento (PND) como uma "nova era para o ambientalismo e para o desenvolvimento correlato da legislação", reconhece o caráter exploratório sob o qual a natureza era posta. Criticando a maneira assistemática e setorial da proteção ao ambiente, assevera que a legislação "até então não se preocupava em proteger o meio ambiente de forma específica e global, dele cuidando de maneira diluída, e mesmo casual, e na exata medida em que pudesse atender sua exploração pelo homem" (MILARÉ, 2013, p. 240) (Grifos nossos).

\subsection{O MARCO CONSTITUCIONAL DE 1988}

Com o fim da ditadura militar no Brasil, a participação democrática da sociedade civil na esfera governamental ganha impulso. Diversos setores da sociedade se organizam em torno da redemocratização do país e da elaboração de 
uma nova carta constitucional. Cabe destacar a atuação do movimento ambientalista na elaboração de um capítulo na Constituição voltado exclusivamente para a proteção do meio ambiente.

Economicamente, com o crescimento da produção industrial e do setor de serviços (em 1985 a indústria e os serviços correspondiam a 34 e 55\% do Produto Interno Bruto, respectivamente), o país deixa de ser um país agrário. Longe de ficar estagnado, contudo, a agricultura vivenciou novas dinâmicas: a produção cafeeira, em declínio em função da concorrência internacional e da queda dos preços, foi substituída por produções mais rentáveis que articulavam agricultura e indústria (denominada agroindústria), como a soja no Paraná e a laranja no interior de São Paulo (FAUSTO, 2003).

Novos problemas ambientais, então, advindos de várias frentes (indústria, agroindústria, cidade) demandavam uma regulamentação mais efetiva e eficiente na proteção do meio ambiente que colocasse sobre um novo eixo a política de defesa ambiental.

Uma mudança substancial nas políticas ambientais brasileiras deu-se a partir de 1988, com a promulgação da nova Constituição Federal. Nela foi inserido um capítulo dedicado ao meio ambiente (Capítulo VI, art. 225), trazendo novos paradigmas para a proteção ambiental sob os seguintes termos:

Art. 225. Todos têm Direito ao meio ambiente ecologicamente equilibrado, bem de uso comum do povo e essencial à sadia qualidade de vida, impondo-se ao Poder Público e à coletividade o dever de defendê-lo e preservá-lo para as presentes e futuras gerações.

$\S 1 \stackrel{0}{ }$ Para assegurar a efetividade desse Direito, incumbe ao Poder Público:

I - preservar e restaurar os processos ecológicos essenciais e prover 0 manejo ecológico das espécies e ecossistemas;

II - preservar e restaurar os processos ecológicos essenciais e prover 0 manejo ecológico das espécies e ecossistemas;

III - definir, em todas as Unidades da Federação, espaços territoriais e seus componentes a serem especialmente protegidos, sendo a alteração e a supressão permitidas somente através de ei, vedada qualquer utilização que comprometa a integridade dos atributos que justifiquem sua proteção;

IV - exigir, na forma da lei, para instalação de obra ou atividade potencialmente causadora de significativa degradação do meio ambiente, a que se dará publicidade;

V - controlar a produção, a comercialização e o emprego de técnicas, métodos e substâncias que comportem risco para a vida, a qualidade de vida e o meio ambiente;

VI - promover a educação ambiental em todos os níveis de ensino e a conscientização pública para a preservação do meio ambiente; 
VII - proteger a fauna e a flora, vedadas, na forma da lei, as práticas que coloquem em risco sua função ecológica, provoquem a extinção de espécies ou submetam os animais à crueldade;

$\S 2^{\circ}$ - aquele que explorar recursos minerais fica obrigado a recuperar o meio ambiente degradado, de acordo com solução técnica exigida pelo órgão público competente, na forma da lei;

$\S 3^{\circ}$ - as condutas e atividades consideradas lesivas ao meio ambiente sujeitarão os infratores, pessoas físicas ou jurídicas, a sanções penais e administrativas, independente da obrigação de reparar os danos causados;

§o 4 - a Floresta Amazônica brasileira, a Mata Atlântica, a Serra do Mar, o Pantanal Matogrossense e a Zona Costeira são patrimônio nacional, e sua utilização far-se-á, na forma da lei, dentro de condições que assegurem a preservação do meio ambiente, inclusive quanto aos recursos naturais;

$\S 5^{\circ}$ - são indisponíveis as terras devolutas ou arrecadadas pelos Estados, por ações discriminatórias, necessárias à proteção dos ecossistemas naturais;

$\S 60$ - as usinas que operem com reator nuclear deverão ter sua localização definida em lei federal, sem o que não poderão ser instaladas.

Com a Constituição de 1988, o meio ambiente passa a ser tratado nas normas constitucionais de forma sistemática e global: por um lado, o meio ambiente deixa de ser encarado por setores (água, floresta, solo) e passa a ser entendido de forma unitária; por outro, incorpora-se a proteção ambiental como responsabilidade das três esferas da federação (União, Estados e Municípios), da sociedade civil e nas disciplinas atinentes aos direitos fundamentais, à ordem econômica e financeira, à cultura, à política urbana e agrícola.

A proteção ao meio ambiente sofreu um influxo tal que a Carta de 88 é por vezes chamada de constituição verde, constituição ambiental ou constituição ecológica, chegando mesmo a se falar num Estado de Direito Ambiental ou Estado Constitucional Ecológico (CANOTILHO, 2004; ROTHENBURG, 2005; LEITE et al, 2005; MILARÉ, 2013).

Uma constituição ecológica acolhe o ambiente em seu texto de modo a influenciar todo o seu conteúdo, ou seja, a proteção ao meio ambiente forma e informa a consecução de toda norma constitucional (ROTHENBURG, 2005). Portanto, a constituição holisticamente considerada, assevera Rothenburg (2005, p. 817), "possui um componente ambiental fundamental". São os princípios ecológicos, considera José Gomes Canotilho (2004), que devem reger um Estado de Direito Ambiental. 
ambiente, no texto constitucional, nos alerta os autores, deve ser entendido de forma integrativa, ampla, de modo a incluir o ambiente natural e aquele humano, artificial.

Nesse sentido, ademais, uma constituição ecológica aponta para novas formas de comunicação e participação dos cidadãos na elaboração das normas ambientais, porquanto a proteção ao meio ambiente, além de responsabilidade comum do Estado e cidadãos, deve ser feita de forma democrática a permitir diversas representações dos interesses ecológicos (CANOTILHO, 2004). José Gomes Canotilho avalia que:

integrar os cidadãos e as suas organizações nas estratégias regulativas do ambiente representa, afinal, uma das dimensões indispensáveis à concepção integrativa do ambiente, sob pena de esta concepção se transformar num encapuçado plano global do ambiente, sem quaisquer comunicações com o ambiente humano e social (CANOTILHO, 2004, p. 13).

Cunha e Coelho (2012) também tomam a Constituição de 1988 como referência para delimitarem um terceiro e último período das políticas ambientais brasileiras (de 1988 aos dias atuais), "marcado pelos processos de democratização e descentralização decisórias e pela rápida disseminação da noção de desenvolvimento sustentável" (CUNHA \& COELHO, 2012, p. 46).

Com efeito, a política ambiental brasileira testemunha uma crescente participação dos movimentos em defesa do meio ambiente, fruto da coordenação mais sistemática das atividades dos ativistas e membros do movimento ecológico e do contexto das discussões da assembleia constituinte na década de 80 (VIOLA, 1987).

Sobre esta nova fase das políticas ambientais no Brasil, Cunha e Coelho resumem:

O envolvimento da sociedade local nas questões ambientais passou a ser
estimulado. Noções de divisão de responsabilidades e de
complementariedade entre as competências federais, estaduais e
municipais ganham importância, acompanhadas de discussões sobre o
papel dos diversos atores sociais na reformulação das políticas públicas e
no reordenamento das demandas setoriais e regionais (CUNHA e COELHO,
2012, p. 53).

A Carta Magna de 88 é referência igualmente para o socioambientalismo brasileiro porquanto, para Juliana Santilli (2005, p.41), a Constituição "passou a dar sólido arcabouço jurídico ao socioambientalismo". Nessa perspectiva, segundo Santilli, o sistema jurídico-ambiental brasileiro, tanto a legislação quanto a 
interpretação dos artigos legais, passa a revestir-se de um caráter social, expressando preocupações com as populações quilombolas, indígenas, ribeirinhos e com as culturas e legitimidade dos conhecimentos associados que, além de promover a proteção da natureza, promovem a justiça socioambiental (SANTILLI, 2005).

[O socioambientalismo] desenvolveu-se com base na concepção de que, em um país pobre e com tantas desigualdades sociais, um novo paradigma de desenvolvimento deve promover não só a sustentabilidade estritamente ambiental - ou seja, a sustentabilidade de espécies, ecossistemas e processos ecológicos - como também a sustentabilidade social - ou seja, deve contribuir também para a redução da pobreza e das desigualdades sociais e promover valores como justiça social e equidade. Além disso, o novo paradigma de desenvolvimento preconizado pelo socioambientalismo deve promover e valorizar a diversidade cultural e a consolidação do processo democrático no país, com ampla participação social na gestão ambiental (SANTILLI, 2005, p.34).

Conclui, por fim, a autora:

o texto constitucional revela a compreensão de que não basta proteger a biodiversidade: a diversidade de espécies, genética e de ecossistemas, sem assegurar a diversidade cultural que está intimamente relacionada a esta. A síntese socioambiental está presente na interface entre biodiversidade e sociodiversidade, permeada pelo multiculturalismo, pela plurietnicidade e pelo enfoque humanista (SANTILLI, 2005, p. 93).

Entretanto, os valores e ideias gerais que orientam as políticas ambientais continuaram fortemente caracterizados pelo valor econômico dos bens ambientais, observam Cunha e Coelho (2012). Não obstante a proteção ao meio ambiente tenha adquirido nova dimensão, principalmente com a inserção da questão social tanto em termos de participação quanto no conceito, uma ótica economicista prevalece como valor de grande peso na definição das políticas públicas.

Discorrendo sobre as crenças, ideias e valores que influenciaram a formulação de políticas públicas para o meio ambiente, os autores asseveram que, de fato, uma corrente instrumental foi hegemônica em relação à corrente ecocêntrica na emergência do novo paradigma de proteção ambiental dos anos 80 e 90 . Enquanto, por um lado, a corrente ecocêntrica visualiza a Terra em termos de biosfera, um imenso ser vivo, a corrente instrumental, por outro,

prega a proteção do planeta por seu valor econômico, sem desafiar os fundamentais filosóficos da sociedade industrial. Concebe o planeta como um sistema gigante de recursos, e o termo conservação é sinônimo de manejo eficiente dos recursos com o objetivo de obter níveis ótimos de produção sem ameaçar a reposição de seus estoques. As noções de manejo, monitoramento e planejamento do uso dos recursos naturais são 
caras frente à corrente instrumental, preocupada em assegurar o fornecimento contínuo de matérias-primas para a indústria e comprometida com o discurso de progresso (CUNHA e COELHO, 2012, p. 56).

Em 1992 acontece no Rio de Janeiro a Conferência das Nações Unidas sobre meio ambiente e desenvolvimento, conhecida como Rio-92, momento em que se reconhece a necessidade de se conciliar o desenvolvimento econômico com a utilização dos recursos naturais. Em decorrência do encontro, o Brasil ratifica: I) a Convenção-Quadro das Nações Unidas sobre a Mudança do Clima, estabelecendo dentro da administração pública uma "estrutura responsável pela coordenação da implantação da Convenção no país, ou seja, a Coordenadoria de Mudanças do Clima" e; II) a Convenção sobre Diversidade Biológica, comprometendo-se à conservação e utilização sustentável da biodiversidade nacional. Deve-se mencionar também a implantação da Agenda 21, programa de ações que propõe objetivos, atividades, instrumentos e estruturação humana e institucional para o desenvolvimento sustentável.

Neste último período, multiplicaram-se a criação de unidades de conservação (os autores citam a criação de 119 unidades de conservação entre 1988 a 2001) e o Instituto Brasileiro de Meio Ambiente e Recursos Naturais Renováveis (IBAMA) vem substituir o Instituto Brasileiro de Desenvolvimento Florestal (IBDF).

Por outro lado, houve um avanço na edição de diplomas legais protetores do meio ambiente, dentre os quais podemos mencionar:

- Lei 9.433 de 8 de janeiro de 1997 (institui a Política Nacional de Recursos Hídricos);

- Lei 9.605 de 12 de fevereiro de 1998 (dispõe dos crimes ambientais);

- Lei 9.795 de 27 de abril de 1999 (institui a Política Nacional de Educação Ambiental);

- Decreto № 4.339 de 22 de agosto de 2002 (institui a Política Nacional da Biodiversidade);

- Lei 12.305 de 2 de agosto de 2010 (institui a Política Nacional de Resíduos Sólidos);

- Lei 12.651 de 25 de maio de 2012 (institui o novo Código Florestal); 
Concomitantemente, o Estado passa a promover políticas indutoras do desenvolvimento sustentável, embora ainda formule e implemente, ao mesmo tempo, políticas dilapidadoras dos recursos ambientais (CUNHA e COELHO, 2012). Assim, por exemplo, a Lei 11.284 de 02 de março de 2006 acrescentou à Lei 6.938/1981 uma série de instrumentos de preservação ambiental relacionadas à atividade econômica. "Nesse sentido, a Lei 11.284/2006 inaugura 'um novo tipo' de regulamentação, ou seja, a instituição direta de regras ambientais voltadas à preocupação com a atividade econômica" (MILARÉ, 2013, p. 848).

Mecanismos de mercado, como as certificações ambientais ou a privatização de recursos naturais também ganharam força neste último período como uma forma não estatal de proteção natural, transferindo para particulares e setores empresariais a responsabilidade de preservação do meio ambiente (CUNHA e COELHO, 2012). 


\section{DIREITO AMBIENTAL: DOUTRINA, PRINCÍPIOS E CONCEITOS}

O escopo central deste trabalho é discutir, geograficamente, o Direito Ambiental brasileiro. Para tanto, reuniu-se primeiramente um conjunto de doutrinadores pátrios a fim de analisar os princípios e conceitos empregados no Direito Ambiental relativos ao meio ambiente, além de avaliar como é entendida, pela doutrina, a relação do homem com o meio.

Doutrina é um termo de acepção ampla. Na raiz latina docere, doctrina é ensino, educação, instrução (SARAIVA, 2000). Nos dicionários modernos significa tanto o conjunto de ideias e princípios que servem de base a um sistema religioso, político, filosófico ou científico, quanto a opinião de um autor sobre determinado assunto (FERREIRA, 1986; SILVA, 2008).

Na esfera do Direito, segundo De Plácido e Silva, doutrina é, em sentido lato, "o conjunto de princípios expostos nos livros de Direito, em que se firmam teorias ou se fazem interpretações sobre a ciência do Direito". Em sentido estrito, diz ainda o autor, "quer significar a opinião particular, admitida por um ou vários jurisconsultos, a respeito de um ponto de Direito controverso" (SILVA, 2008, p. 503).

A doutrina jurídica desempenha importante papel dentro do Direito desde a elaboração das normas até a sua sistematização, interpretação e aplicação. Conceitualmente, Maria Helena Diniz define doutrina como atividade científicojurídica, ou seja,

[são] estudos científicos realizados pelos juristas, na análise e sistematização de normas jurídicas, na elaboração das definições dos conceitos jurídicos, na interpretação das leis, facilitando e orientando a tarefa de aplicar o Direito, e na apreciação de justiça ou conveniência dos dispositivos legais, adequando-os aos fins que o Direito deve perseguir, emitindo juízos de valor sobre o conteúdo da ordem jurídica, apontando as necessidades e oportunidades das reformas jurídicas (DINIZ, 2004, p. 316).

Para Maria Helena Diniz, a doutrina é, ainda, fonte de direito costumeiro, uma vez que "é importante recurso à produção de normas individuais para preencher determinadas lacunas, sendo valiosa fonte de cognição" (DINIZ, 2004, p. 318).

Em posição contrária, coloca-se Miguel Reale, o qual recusa a qualificação de fonte de direito para a doutrina. Esta, para o autor, não é fonte de direito, pois ela "não se desenvolve numa "estrutura de poder", que é um requisito essencial ao conceito de fonte" (REALE, 2000, p. 176). A produção de normas jurídicas, segundo 
Reale, sempre pressupõe uma estrutura de poder capaz de garantir o adimplemento das normas (REALE, 2000).

Porém, para além da controvérsia sobre fontes de direito, cabe reter a importância da doutrina jurídica dentro do Direito. De fato, as elaborações doutrinárias conduzem em muito o trabalho dos juristas, não raro sendo a fonte principal para aquisição de conhecimento ou o manual primeiro para o entendimento das normas.

Para Maria Helena Diniz: "é a doutrina que constrói noções gerais, conceitos relevantes na elaboração, reforma e aplicação do Direito, devido à sua grande influência na legislação e na jurisprudência" (DINIZ, 2004, p. 319).

Conclui, por fim, Miguel Reale: "os modelos doutrinários envolvem as fontes de direito desde a emanação das normas, desde o momento da produção dos modelos jurídicos prescritivos, até o momento de interpretação e aplicação dos modelos" assevera Reale (2000, p. 177).

No Brasil, as primeiras doutrinas de Direito Ambiental surgem na década de 70 com Sérgio Ferraz e Diogo de Figueiredo Moreira Neto. São nas décadas seguintes, contudo, que se desenvolve e constitui um corpo doutrinário mais consolidado, acompanhando a crescente importância do meio ambiente no sistema jurídico nacional.

Os doutrinadores aqui analisados foram selecionados tendo por referência as ementas do curso de Direito de 12 universidades do Sul e Sudeste brasileiro. Os resultados com os autores, obras, universidades e número total de citações constam no quadro 1. 
Quadro 1 - Autores e Obras citados por Universidade ${ }^{11}$

\begin{tabular}{|c|c|c|c|}
\hline AUTOR & OBRA & UNIVERSIDADE & $\begin{array}{c}\text { № DE } \\
\text { CITAÇÕES }\end{array}$ \\
\hline $\begin{array}{c}\text { Paulo de Bessa } \\
\text { Antunes }\end{array}$ & $\begin{array}{l}\text { Curso de Direito } \\
\text { Ambiental }\end{array}$ & $\begin{array}{l}\text { UENP; UERJ; UFES; UFJF; UFMG; UFPR; UFSM; UNIRIO; } \\
\text { UFU; USP (Departamento de Direito econômico, financeiro } \\
\text { e tributário - DEF0566 Direito Ambiental*); USP }{ }^{\star *} \\
\text { (Departamento de Direito público - DDP5004 Direito } \\
\text { Ambiental I); USP (Departamento de Direito econômico, } \\
\text { financeiro e tributário - DEF0514 Direito Ambiental I**); } \\
\text { USP (Departamento de Direito econômico, financeiro e } \\
\text { tributário - DEF0563 Direito Ambiental }{ }^{\star * * *} \text { ) }\end{array}$ & 13 \\
\hline $\begin{array}{l}\text { Paulo Affonso } \\
\text { Leme Machado }\end{array}$ & $\begin{array}{c}\text { Direito Ambiental } \\
\text { Brasileiro }\end{array}$ & $\begin{array}{l}\text { UENP; UERJ; UFES; UFJF; UFMG; UFPR; UFSM; UNIRIO; } \\
\text { UFU; USP* (Departamento de Direito Público - DDP5004 } \\
\text { Direito Ambiental I); USP (Departamento de Direito } \\
\text { econômico, Financeiro e Tributário - DEF0514 Direito } \\
\text { Ambiental I**); USP (Departamento de Direito Econômico, } \\
\text { Financeiro e Tributário - DEF0563 Direito Ambiental }{ }^{\star * \star *} \text { ) }\end{array}$ & 12 \\
\hline Cristiane Derani & $\begin{array}{l}\text { Direito Ambiental } \\
\text { Econômico }\end{array}$ & $\begin{array}{l}\text { UFU; UFES; UFJF; UFRRJ; USP (Departamento de Direito } \\
\text { econômico, financeiro e tributário - DEF0566 Direito } \\
\text { Ambiental }^{\star} \text { ); USP** (Departamento de Direito público - } \\
\text { DDP5004 Direito Ambiental I); USP (Departamento de } \\
\text { Direito econômico, financeiro e tributário - DEF0514 Direito } \\
\text { Ambiental I***); USP (Departamento de Direito econômico, } \\
\text { financeiro e tributário - DEF0563 Direito Ambiental }{ }^{* * * *} \text { ) }\end{array}$ & 8 \\
\hline Édis Milaré & $\begin{array}{c}\text { Direito Ambiental: } \\
\text { doutrina, prática, } \\
\text { jurisprudência, } \\
\text { glossário } \\
\text { (Direito do Meio } \\
\text { Ambiente) }\end{array}$ & $\begin{array}{l}\text { UENP; UFES; UFPR; UFSM; UNIRIO; USP } \\
\text { (Departamento de Direito público - DDP5004 Direito } \\
\text { Ambiental I); USP (Departamento de Direito econômico, } \\
\text { financeiro e tributário - DEF0514 Direito Ambiental I }{ }^{* * *} \text { ) }\end{array}$ & 7 \\
\hline $\begin{array}{l}\text { Luis Paulo } \\
\text { Sirvinskas }\end{array}$ & $\begin{array}{c}\text { Manual de Direito } \\
\text { Ambiental }\end{array}$ & UNEP; UEMG; UFPR; UFRRJ; UFSM; UFU & 6 \\
\hline $\begin{array}{l}\text { José Afonso da } \\
\text { Silva }\end{array}$ & $\begin{array}{l}\text { Direito Ambiental } \\
\text { Constitucional }\end{array}$ & $\begin{array}{l}\text { UENP; UFPR; UFSM; USP }{ }^{* *} \text { (Departamento de Direito } \\
\text { público - DDP5004 Direito Ambiental I); USP (Departamento } \\
\text { de Direito econômico, financeiro e tributário - DEF0514 } \\
\text { Direito Ambiental I***) }\end{array}$ & 5 \\
\hline $\begin{array}{l}\text { Celso Antonio } \\
\text { Pacheco Fiorillo }\end{array}$ & $\begin{array}{c}\text { Curso de Direito } \\
\text { Ambiental brasileiro }\end{array}$ & UENP; UFES; UFPR; UFRRJ; UFU & 5 \\
\hline
\end{tabular}

Fonte: Elaborado pelo autor com base nos dados da pesquisa, 2015.

${ }^{11}$ Doutrinadores, obras e universidades. Elaborado por Jonas Dias de Souza. * Docente responsável: Cristiane Derani; ${ }^{* \star}$ Faculdade de Direito de Ribeirão Preto; ${ }^{\star \star \star}$ Docente responsável: Ana Maria de Oliveira Nusdeo; ${ }^{* \star \star \star}$ Docente responsável: Fábio Nusdeo; ${ }^{* \star * *}$ Docente responsável: Raul Miguel Freitas de Oliveira. Faculdades pesquisadas: Universidade do Estado de Minas Gerais (UEMG); Universidade Estadual do Norte do Paraná (UENP); Universidade do Estado do Rio de Janeiro (UERJ); Universidade Federal do Espírito Santo (UFES); Universidade Federal de Juiz de Fora (UFJF); Universidade Federal de Minas Gerais (UFMG); Universidade Federal do Paraná (UFPR); Universidade Federal Rural do Rio de Janeiro (UFRRJ); Universidade Federal de Santa Maria (UFSM); Universidade Federal de Uberlândia (UFU); Universidade Federal do Estado do Rio de Janeiro (Unirio); Universidade de São Paulo (USP). 


\subsection{PRINCÍPIOS DO DIREITO AMBIENTAL}

$\mathrm{Na}$ esfera do Direito, princípio é um valor fundamental que baliza a correta elaboração, entendimento, interpretação e aplicação da norma, auxiliando o legislador, o jurista e o aplicador da lei na execução de suas tarefas.

Segundo Celso Antônio Bandeira de Mello, um princípio é:

mandamento nuclear de um sistema, verdadeiro alicerce dele, disposição fundamental que se irradia sobre diferentes normas compondo-lhe o espírito e servindo de critério para sua exata compreensão e inteligência exatamente por definir a lógica e a racionalidade do sistema normativo, no que lhe confere a tônica e the dá sentido harmônico (MELLO, 1980 apud MILARÉ, 2013, p. 257) ${ }^{12}$.

Sirvinskas (2016) diz ser por meio dos princípios que se estabelece o conteúdo valorativo das normas, exigindo sua realização da melhor forma possível.

Por força legal, os princípios também podem ser usados em caso de omissão da lei (Decreto Lei no 4.657/1942 - Lei de Introdução às Normas do Direito Brasileiro, art. 4ำ). Nesse sentido, aduz Carlos Maximiliano (2011), configuram-se como verdadeiras "diretivas gerais do hermeneuta":

se é deficiente o repositório de normas, se não oferece, explicita ou
implicitamente, e nem sequer por analogia, o meio de regular ou resolver
um caso concreto, o estudioso, o magistrado ou funcionário administrativo
como que renova, em sentido inverso, o trabalho do legislador. Este
procede de cima para baixo, de geral ao particular; sobe aquele
gradativamente, por indução, da ideia em foco para outra mais elevada,
prossegue em generalizações sucessivas, e cada vez mais amplas, até
encontrar a solução colimada (MAXIMILIANO, 2011, p.240).

No conjunto da doutrina pesquisada, inexiste unanimidade quanto aos princípios que regem o Direito Ambiental. Cada autor enumera e denomina os princípios que julga existir segundo critérios próprios. Os princípios, por autor, são mostrados no quadro 2. Cabe ressalvar que outros doutrinadores, além daqueles selecionados anteriormente, foram incorporados à pesquisa já que foram objetos de análise das primeiras investigações.

Tendo em vista os objetivos almejados neste trabalho, vamos analisar aqueles princípios que mais diretamente se relacionam ao meio ambiente. Ademais, apesar da quantidade de princípios enumerados pelo conjunto de doutrinadores

\footnotetext{
${ }^{12}$ MELLO, Celso Antônio Bandeira de. Elementos de Direito Administrativo. Ed. RT, São Paulo, 1980.
} 
selecionados, o conteúdo de alguns princípios coincide uns com os outros, embora sob diferentes denominações. 
Quadro 2 - Autores e Princípios de Direito Ambiental

\begin{tabular}{|c|c|c|c|c|c|c|c|c|c|c|c|}
\hline \multirow{2}{*}{ PRINCÍPIO } & \multicolumn{11}{|c|}{ AUTORES } \\
\hline & Antunes & Machado & Derani & Milaré & Sirvinkas & Fiorillo & Weyermuller & $\begin{array}{l}\text { Phillippi Jr; } \\
\text { Rodrigues }\end{array}$ & Seguim & Sampaio & Beltrão \\
\hline Princ. da capacidade de suporte & $x$ & & & & & & & & & & \\
\hline $\begin{array}{l}\text { Princ. da consideração da variável ambiental no } \\
\text { processo decisório de políticas de desenvolvimento }\end{array}$ & & & & $\mathbf{x}$ & & & & & & & $\mathbf{x}$ \\
\hline Princ. da cooperação entre os povos & & & & $\mathbf{x}$ & & & $\mathbf{x}$ & $\mathbf{x}$ & & & \\
\hline Princ. da dignidade da pessoa humana & $\mathbf{x}$ & & & & & & & & & & \\
\hline Princ. da educação ambiental & & & & & & & & $\mathbf{x}$ & & & \\
\hline Princ. da equidade/solidariedade intergeracional & & & & $\mathbf{x}$ & & & $\mathbf{x}$ & & & $\mathbf{x}$ & \\
\hline Princ. socioambiental da propriedade & & & & $\mathbf{x}$ & & & & & & & \\
\hline Princ. da informação & & $\mathbf{x}$ & & & & & & $\mathbf{x}$ & $\mathbf{x}$ & $\mathbf{x}$ & $\mathbf{x}$ \\
\hline Princ. da natureza pública da proteção ambiental & & & & $\mathbf{x}$ & & & & $\mathbf{x}$ & & & \\
\hline Princ. da notificação & & & & $\mathbf{x}$ & & & & $\mathbf{x}$ & $\mathbf{x}$ & & \\
\hline Princ. da obrigatoriedade da intervenção estatal & & $\mathbf{x}$ & & $\mathbf{x}$ & & & & $\mathbf{x}$ & $\mathbf{x}$ & & \\
\hline Princ. da participação (cooperação) comunitária & & $\mathbf{x}$ & $\mathbf{x}$ & $\mathbf{x}$ & $\mathbf{x}$ & $\mathbf{x}$ & & $\mathbf{x}$ & $\mathbf{x}$ & $\mathbf{x}$ & $\mathbf{x}$ \\
\hline Princ. da precaução & $\mathbf{x}$ & $\mathbf{x}$ & $\mathbf{x}$ & $\mathbf{x}$ & $\mathbf{x}$ & & & $\mathbf{x}$ & $\mathbf{x}$ & $\mathbf{x}$ & $\mathbf{x}$ \\
\hline Princ. da prevenção & $\mathbf{x}$ & $\mathbf{x}$ & & $\mathbf{x}$ & $\mathbf{x}$ & $\mathbf{x}$ & & $\mathbf{x}$ & $\mathbf{x}$ & $\mathbf{x}$ & $\mathbf{x}$ \\
\hline Princ. da proibição do retrocesso ambiental & & & & $\mathbf{x}$ & $x$ & $\mathbf{x}$ & & & & & \\
\hline Princ. da reparação & & $\mathbf{x}$ & & & & & & & & & \\
\hline Princ. da responsabilidade & $\mathbf{x}$ & & & & & & & & $\mathbf{x}$ & & \\
\hline Princ. da responsabilidade ecológica & & & & & & & & & & $\mathbf{x}$ & \\
\hline
\end{tabular}

(continua) 
(continuação)

\begin{tabular}{|c|c|c|c|c|c|c|c|c|c|c|c|}
\hline \multirow{2}{*}{ PRINCÍPIO } & \multicolumn{11}{|c|}{ AUTORES } \\
\hline & Antunes & Machado & Derani & Milaré & Sirvinkas & Fiorillo & Weyermuller & $\begin{array}{l}\text { Phillippi Jr; } \\
\text { Rodrigues }\end{array}$ & Seguim & Sampaio & Beltrão \\
\hline \multicolumn{12}{|l|}{ Princ. da responsabilidade estatal } \\
\hline Princ. da responsabilidade socioambiental & & & & & $\mathbf{x}$ & & & & & & \\
\hline Princ. da ubiquidade & & & & & & $\mathbf{X}$ & & $\mathbf{X}$ & & & \\
\hline Princ. democrático & $\mathbf{x}$ & & & & $\mathbf{x}$ & & & & & & \\
\hline Princ. do acesso equitativo dos recursos naturais & & $\mathbf{x}$ & & & & & & & & & \\
\hline Princ. do controle do poluidor pelo poder público & & & & $\mathbf{x}$ & & & & & & & \\
\hline Princ. do desenvolvimento sustentável & & & & & $\mathbf{x}$ & $\mathbf{x}$ & $\mathbf{x}$ & $\mathbf{x}$ & & $\mathbf{X}$ & \\
\hline Princ. do Direito ao desenvolvimento & $\mathbf{x}$ & & & & & & & & & & \\
\hline $\begin{array}{l}\text { Princ. do Direito ao meio ambiente (ecologicamente) } \\
\text { equilibrado }\end{array}$ & & $\overline{\mathbf{X}}$ & & $\mathbf{X}$ & & & & $\mathbf{X}$ & & & \\
\hline Princ. do equilíbrio & $\mathbf{X}$ & & & & $\mathbf{X}$ & & & & & & \\
\hline Princ. do poluidor pagador & $\mathbf{X}$ & $\mathbf{X}$ & $\mathbf{X}$ & $\mathbf{X}$ & $\mathbf{X}$ & $\mathbf{X}$ & $\mathbf{X}$ & $\mathbf{X}$ & $\mathbf{X}$ & & $\mathbf{X}$ \\
\hline Princ. do protetor recebedor & & & & $\mathbf{X}$ & $\mathbf{X}$ & & & & & & \\
\hline Princ. do usuário pagador & & $\mathbf{X}$ & & $\bar{X}$ & $\mathbf{X}$ & & & & & & $\bar{X}$ \\
\hline Princ. do limite & & & & & $\mathbf{X}$ & & & & & & \\
\hline Princ. do Direito humano & & & & & $\mathbf{X}$ & & & & & & \\
\hline
\end{tabular}

Fonte: elaborado pelo autor a partir dos dados da pesquisa, 2015. 


\subsubsection{Princípio do meio ambiente ecologicamente equilibrado}

Um dos mais autorizados juristas do Direito Ambiental brasileiro, Paulo Affonso Leme Machado, elenca onze princípios gerais, dos quais nos interessa aqui, primeiro, o princípio do meio ambiente ecologicamente equilibrado. Define o autor que "o direito ao meio ambiente equilibrado, do ponto de vista ecológico, consubstancia-se na conservação das propriedades e das funções naturais desse meio, de forma a permitir a 'existência, e evolução e o desenvolvimento dos seres vivos"” (MACHADO, 2010, p. 57-8).

Lembra que equilíbrio não significa uma situação de estabilidade absoluta porquanto "todo ecossistema é evolutivo", mas é preciso identificar "situações que conduzem as comunidades naturais a uma maior ou menor instabilidade" (MACHADO, 2010, p. 59). Afirma ainda que

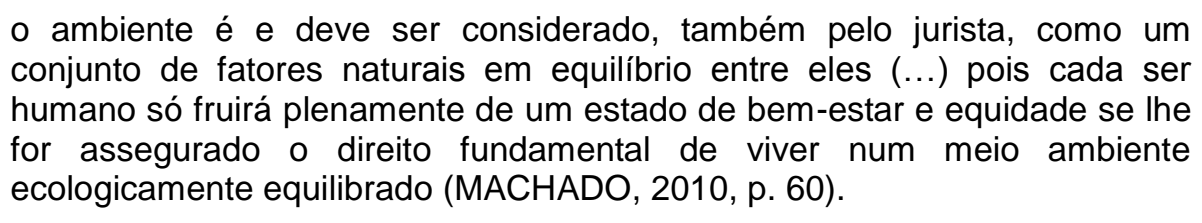

Édis Milaré (2013) enxerga o princípio do meio ambiente ecologicamente equilibrado como uma extensão do direito à vida, seja considerando a existência física, a saúde ou a dignidade do ser humano. Esse novo direito fundamental da pessoa humana, no dizer de Milaré, significa o "desfrute de adequadas condições de vida em um ambiente saudável, ou, na dicção da lei, 'ecologicamente equilibrado'” (2013, p. 258).

\subsubsection{Princípio do direito à sadia qualidade de vida}

Um segundo princípio elencado por Machado é o princípio do direito à sadia qualidade de vida. Nas palavras do jurista:

A saúde dos seres humanos não existe somente numa contraposição a não ter doenças diagnosticadas no presente. Leva-se em conta o estado dos elementos da Natureza - água, solo, ar, flora, fauna e paisagem - para se aquilatar se esses elementos estão em estado de sanidade e de seu uso advenham saúde ou doenças e incômodos para os seres humanos (MACHADO, 2010, p. 62). 
Atrelando o Direito Econômico e o Direito Ambiental na busca do conceito de qualidade de vida, Cristiane Derani assevera que "tal expressão traz o condão de traduzir todo o necessário aparato interno e externo ao homem, dando-Ihe condições de desenvolver suas potencialidades como indivíduo e como parte fundamental da sociedade" (DERANI, 2001, p. 81).

Para Derani, qualidade de vida como expresso e segundo o sentido atribuído pelo Direito Ambiental, surgiu como complemento do sentido dado pela economia, de caráter mais quantitativo e centrada em conquistas materiais. Desse modo, afirma:

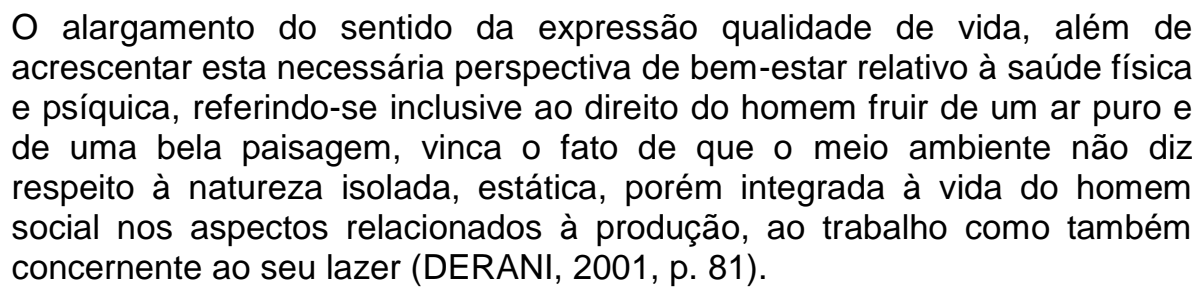

Conclui mais a frente: "tal implica que nem pode ser entendida como apenas o conjunto de bens e comodidade materiais, nem como a tradução do ideal da volta à natureza, expressando uma reação e indiscriminado desprezo a toda elaboração técnica e industrial" (DERANI, 2001, p. 81).

\subsubsection{Princípio do acesso equitativo dos recursos naturais}

Seguindo ainda os princípios enumerados por Machado, o princípio do acesso equitativo aos recursos naturais significa que "os bens que integram o meio ambiente planetário, como a água, ar e solo, devem satisfazer as necessidades comuns de todos os habitantes da Terra" (MACHADO, 2010, p. 62-3).

\subsubsection{Princípio da informação}

O princípio da informação também fundamenta o Direito Ambiental. Procurando a "dimensão da informação sobre o meio ambiente", Machado cita a Convenção sobre o Acesso à Informação, a Participação do Público no Processo Decisório e o Acesso à Justiça em Matéria de Meio Ambiente, que no seu artigo $2^{\circ}$ designa informação como o "estado do meio ambiente, tais como o ar, e a atmosfera, as águas, o solo, as terras, a paisagem e os sítios naturais, a diversidade 
biológica e seus componentes, compreendidos os OGMs, e a interação desses elementos" (MACHADO, 2010, p. 97).

Beltrão (2009) nos lembra da Lei 6.938/1981, artigo 9º, incisos VII e XI, que impõem o sistema nacional de informação sobre o meio ambiente e a garantia de prestação de informações relativas ao meio, funcionando como instrumentos de informação da população. Igualmente a Lei 10.650/2003 que dispõe sobre o acesso público aos dados e informações existentes nos órgãos e entidades integrantes do Sistema Nacional do Meio Ambiente (SISNAMA). Diz Beltrão:

\begin{abstract}
Os órgãos e entidades da administração pública passam a ter a obrigação legal de fornecer "todas as informações ambientais que estejam sob sua guarda, em meio escrito, visual, sonoro ou eletrônico, especialmente relativas a: (I) qualidade do meio ambiente; (II) políticas, planos, e programas potencialmente causadores de impacto ambiental; (III) resultados de monitoramento e auditoria nos sistemas de controle de poluição e de atividades potencialmente poluidoras, bem como de planos e ações de recuperação de áreas degradadas; (IV) acidentes, situações de risco ou de emergência ambientais; (V) emissões de efluentes líquidos e gasosos, e produção de resíduos sólidos; (VI) substâncias tóxicas e perigosas; (VII) diversidade biológica; (VIII) organismos geneticamente modificados (BELTRÃO, 2009, p. 43).
\end{abstract}

\title{
5.1.5 Princípio do desenvolvimento sustentável
}

Outro importante princípio que rege o Direito Ambiental é o princípio do desenvolvimento sustentável.

Historicamente, a ideia de desenvolvimento sustentável surgiu na Conferência de Estocolmo de 1972 de forma ainda embrionária, assevera Weyermüller (2010), pois a dita Conferência, diz Geraldo Eulálio do Nascimento e Silva (1995), preocupava-se precipuamente com a poluição dos rios, dos lagos e mares e da atmosfera. Considerava-se, então, a equação entre desenvolvimento e preservação do meio ambiente impraticável.

Posteriormente, a teoria de desenvolvimento sustentável foi formulada pela Comissão Mundial sobre Desenvolvimento e Meio Ambiente da ONU em 1983 e remetia ao relatório "The Limits of Growth" publicado pelo $\mathrm{MIT}^{13}$ na década de 70.0 Relatório Meadowns, como ficou conhecida a publicação do MIT, mostrava que o mundo passaria por inelutáveis cataclismas caso as taxas de crescimento, de utilização de recursos naturais, o aumento do consumo de alimentos e a crescente

\footnotetext{
${ }^{13}$ MIT: Massachusetts Institute of Technology.
} 
poluição mantivessem-se inalterados. Embora o prognóstico não se confirmasse, o Relatório Meadowns levou a Comissão Mundial sobre Desenvolvimento e Meio Ambiente a formular a tese de desenvolvimento sustentável (NASCIMENTO E SILVA, 1995, p. 48).

A ideia de desenvolvimento sustentável ganhou força com o Relatório Brundtland, publicado em 1988 sob o título Nosso Futuro Comum, e consagrou-se como princípio a partir da ECO-92 (SIRVINSKAS, 2016).

Sustentabilidade, consoante Weyermüller, é a correta gestão de recursos naturais, a fim de impedir escassez ou inexistência de elementos explorados hoje equivocadamente: "busca-se a harmonização das necessidades materiais e as necessidades de preservar o meio ambiente" (WEYERMÜLLER, 2010, p. 34).

Para Sirvinskas:

\begin{abstract}
Sustentabilidade, em outras palavras, tem por finalidade buscar compatibilizar o atendimento das necessidades sociais e econômicas do ser humano com a necessidade de preservação do ambiente. Visa-se, com essa conciliação, assegurar a manutenção de todas as formas de vida na Terra, inclusive a humana. Busca-se, por meio desse princípio, melhorar a qualidade de vida respeitando a capacidade de suporte dos ecossistemas. Objetiva-se, com isso, a diminuição da miséria, da exclusão social e econômica, do consumismo, do desperdício e da degradação ambiental (SIRVINSKAS, 2016, p. 146).
\end{abstract}

Com a tomada de consciência pública sobre os problemas e riscos ambientais que a sociedade enfrenta, a ideia de desenvolvimento sustentável tenta conciliar as orientações da economia com as exigências ambientais. Destarte, para Edith Brown Weiss "o Princípio do Desenvolvimento Sustentável requer que os recursos renováveis (...) não sejam explorados num nível superior aos de suas taxas de reposição" (WEISS, 1990 apud PHILIPPI \& RODRIGUES, 2005, p. 8) ${ }^{14}$. Também Gerd Winter entende que a sustentabilidade "permite a destruição de bens ambientais, se tal destruição for também compatível com a renovação a longo prazo dos recursos" (WINTER, 2005, p. 146). Intenta-se com a sustentabilidade manter a disponibilidade dos recursos naturais para as gerações futuras (princípio da equidade intergeracional).

No mesmo sentido Fiorillo diz:

O princípio do desenvolvimento sustentável tem por conteúdo a manutenção das bases vitais da produção e reprodução do homem e de suas atividades, garantindo igualmente uma relação satisfatória entre os

\footnotetext{
${ }^{14}$ Weiss, Edith Brown 1990, OEIn fairness to future generations, Environment, vol. 32, no. 3, Apr., p. 9
} 
homens e destes com o seu ambiente para que as futuras gerações também tenham oportunidade de desfrutar os mesmos recursos que temos hoje à nossa disposição (FIORILLO, 2013, p. 80).

E mais a frente adverte:

O princípio não objetiva impedir o desenvolvimento econômico. Sabemos que a atividade econômica, na maioria das vezes, representa alguma degradação ambiental. Todavia, o que se procura é minimizá-la, pois pensar de forma contrária significaria dizer que nenhum empreendimento que venha a afetar o meio ambiente poderá ser instalado, e não é essa a concepção apreendida do texto. O correto é que as atividades sejam desenvolvidas lançando-se mão dos instrumentos existentes adequados para a menos degradação possível (FIORILLO, 2013, p. 81).

\subsubsection{Princípio do equilíbrio e princípio da capacidade de suporte}

De certa forma, os princípios da capacidade de suporte, do limite e o princípio do equilíbrio definidos por Antunes e Sirvinskas tentam traduzir esta equação entre desenvolvimento econômico e preservação ambiental, porquanto tais princípios procuram respeitar os limites que o meio ambiente equilibrado possui frente à atividade econômica.

Assim, o princípio do equilíbrio reza que sejam pesadas as consequências ambientais das políticas de intervenção econômica de forma que ela possa ser útil socialmente, mas sem graves danos aos ecossistemas. "Princípio do equilíbrio é o princípio pelo qual devem ser pesadas todas as implicações de uma intervenção no meio ambiente, buscando-se adotar a solução que melhor concilie um resultado globalmente positivo" (ANTUNES, 2013, p. 50).

O princípio da capacidade de suporte é definido por Paulo de Bessa Antunes como "o limite de matéria e energia estranha que o ambiente pode suportar sem alterar suas características básicas e essenciais" (ANTUNES, 2013, p. 50). Limitamse os lançamentos excessivos de matéria e energia despejadas sobre o meio ambiente de maneira a atingir o delicado e difícil equilíbrio entre os benefícios sociais e a manutenção da estabilidade ambiental.

Nesse sentido, Luis Paulo Sirvinskas advoga pelo princípio do limite como a fixação, pelo Poder Público, de parâmetros para o lançamento de "partículas, de ruídos e de presença de corpos estranhos no meio ambiente", sendo dever das autoridades competentes "estabelecer normas administrativas a fim de fixar padrões 
de qualidade ambiental (do ar, das águas, dos ruídos etc.)" (SIRVINSKAS, 2016, p. 149).

\title{
5.1.7 Princípio da prevenção e princípio da precaução
}

Dois princípios dentre os 34 enumerados são os mais citados pela doutrina, quais sejam, o princípio da prevenção e o princípio da precaução.

A par das disputas interpretativas sobre referentes princípios ${ }^{15}$, prevenir e precaver é evitar, antecipadamente, o máximo o risco, o desequilíbrio ambiental e os efeitos negativos para a saúde humana e a qualidade de vida, sejam eles identificados pela ciência ou não. Avalia-se previamente se as ações, as intervenções humanas, trariam desequilíbrio irreversível sobre o meio ambiente ou impactos maiores que os benefícios auferidos.

Tais princípios têm o escopo de evitar danos ao meio ambiente adotando-se medidas e técnicas mitigadoras do desequilíbrio ambiental, que preservem a qualidade de vida e a sanidade ambiental, sem que isso signifique a paralisia das atividades humanas.

Em relação ao princípio da precaução, a articulação mais conhecida é empregada na Declaração do Rio sobre Meio Ambiente e Desenvolvimento:

\begin{abstract}
Com fim de proteger o meio ambiente, o princípio da precaução deverá ser amplamente observado pelos Estados, de acordo com suas capacidades. Quando houver ameaça de danos graves ou irreversíveis, a ausência de certeza científica absoluta não será utilizada como razão para o adiamento de medidas economicamente viáveis para prevenir a degradação ambiental (RIO DE JANEIRO, 1992).
\end{abstract}

Leciona Édis Milaré: "na prática o princípio da prevenção tem como objetivo impedir a ocorrência de danos ao meio ambiente, através da imposição de medidas acautelatórias, antes da implantação do empreendimento e atividades consideradas efetivas ou potencialmente poluidoras" (MILARÉ, 2013, p. 264).

No final, os princípios da precaução e da prevenção almejam controlar os riscos e diminuir os danos em relação à poluição das águas, à destruição das

\footnotetext{
${ }^{15}$ Costuma-se diferenciar na doutrina jurídica prevenção de precaução ou cautela. O primeiro teria por referência riscos e impactos conhecidos; tem-se conhecimento da consequente degradação ambiental que a atividade humana gera de forma a antecipar-se a eles. Já o segundo refere-se a riscos e impactos não conhecidos, desconhecimento que, embora a ciência não tenha certeza absoluta de sua ocorrência, não obsta que se procure evitar ao máximo o risco que se corre de degradação ambiental.
} 
florestas, à perda de diversidade biológica ou à extinção de espécies. No caso de incerteza científica em relação às atividades humanas sobre o meio, prevalece o in dubio pro natura (ANTUNES, 2013), a proteção à natureza, aos elementos naturais.

José Rubens Morato Leite e Patryck de Araújo Ayala, discorrendo sobre os princípios estruturantes do Estado de Direito Ambiental, asseveram:

Com efeito, este princípio reforça a regra de que as agressões ao ambiente,
uma vez consumadas, são normalmente de reparação difícil, incerta e
custosa, e pressupõem uma conduta genérica in dubio pro ambiente (...).
Parte-se dos pressupostos que os recursos ambientais são finitos e os
desejos e a criatividade do homem infinitos, exigindo uma reflexão através
da precaução, se a atividade pretendida, ou em execução, tem como
escopo a manutenção dos processos ecológicos e de qualidade de vida
(LEITE e AYALA, 2015, p. 63-5).

Consoante Machado, o princípio da prevenção, voltado a evitar a consumação de danos ao meio ambiente, é aplicado conforme cinco itens, dentre os quais se destacam: "10) a indicação e inventário das espécies animais e vegetais de um território, quanto à conservação da natureza e identificação das fontes contaminantes das águas e do mar, quanto ao controle da poluição; $2^{\circ}$ ) identificação e inventário dos ecossistemas, com elaboração de um mapa ecológico (...)" (MACHADO, 2010, p. 94).

\subsection{CONCEITOS DO DIREITO AMBIENTAL}

Tão importante quanto os princípios de Direito Ambiental, os conceitos "ambientais" desempenham relevante papel na elaboração, interpretação e aplicação das leis.

O tratamento doutrinário dispensado a estes conceitos não se prende exatamente a uma discussão profunda do sentido de cada vocábulo, apesar de algumas ponderações feitas. Adotam-se, frequentemente, as definições legais para discutir os objetos de maneira propriamente jurídica, sem um questionamento demorado do termo. Vejamos: 


\subsubsection{Meio ambiente}

O conceito central no Direito Ambiental é, pode-se afirmar, o conceito de meio ambiente, pois é a partir dele que irá se definir o objeto com o qual o homem se relaciona.

O conceito legal é dado pela Lei 6.938 de 1981 nos seguintes termos do artigo $3^{\circ}$, inciso I: "meio ambiente, o conjunto de condições, leis, influências e interações de ordem física, química e biológica, que permite, abriga e rege a vida em todas as suas formas".

Embora o conceito legal possa ser considerado para alguns como contendo apenas uma dimensão natural, como para José Afonso da Silva e Luís Paulo Sirvinskas, a doutrina opera uma interpretação extensiva da definição, significando meio ambiente também pela sua dimensão social. Ou seja, na doutrina brasileira de Direito Ambiental, meio ambiente é entendido como a soma dos elementos naturais e sociais que circundam o homem.

Segundo José Afonso da Silva, a definição legal refere-se ao meio ambiente natural, sendo uma concepção, portanto, restrita aos elementos naturais (SILVA, 2009).

Sirvinskas (2016, p. 129) corrobora esse ponto de vista, na medida em que registra que o conceito da lei "é um conceito restrito ao meio ambiente natural", não abrangendo todos os bens jurídicos protegidos.

Sem embargo a estas posições, Leite e Ayala (2015, p. 91) posicionam-se de forma contrária, defendendo que o legislador optou por uma definição ampla de meio ambiente, pois, citando Paulo Affonso Leme Machado, o conceito atinge tudo aquilo que permite a vida, que a abriga e a rege.

Estende-se que o legislador brasileiro teve de optar em sua conceituação e
o fez de maneira correta, pois adotou uma conceituação mais atual,
abarcando vários elementos culturais do ser humano, os quais não podiam
ser excluídos da definição, considerando a necessidade de uma interação
destes com os elementos naturais e artificiais (LEITE \& AYALA, 2015, p. 93).

Nesse sentido, Helena Barreto Custódio defende uma interpretação ampla do conceito, que leve em conta o equilíbrio ecológico e o equilíbrio social:

tanto a definição legal principal que considera o meio ambiente como o conjunto de condições, leis, influências e interações, no campo das Ciências Naturais, de ordem física, química e biológica, que permite, abriga e rege a vida em todas as suas formas (vida humana, animal, vegetal e micro- 
orgânica em geral) como a definição legal complementar que considera o meio ambiente como o patrimônio público a ser necessariamente assegurado e protegido, tendo em vista o uso coletivo, no campo das Ciências Jurídicas, de forma harmônica, compreendem um conjunto de fatores inerentes às relações recíprocas próprias das Leis da Natureza e das Leis Humanas, respectivamente, relacionadas com o equilíbrio ecológico ou equilíbrio ecológico ambiental e com 0 equilíbrio socioeconômico, equilíbrios estes de manutenção e melhorias permanentes e indispensáveis à continuidade da sadia qualidade ambiental propícia à vida em geral e à vida humana em particular. Evidentemente, tanto 0 equilíbrio ecológico ou equilíbrio ecológico ambiental (inerente às Leis da Natureza de ordem física, química e biológica) como o equilíbrio socioeconômico (inerente às Leis Humanas integrantes do Direito Positivo) constituem relevantes conceitos básicos inseparáveis da ampla definição legal (principal e complementar) de meio ambiente (CUSTÓDIO, 2005, p. 80-81).

Na mesma direção, Paulo de Bessa Antunes diz ser criticável a definição da lei uma vez que é fundamental considerar o meio ambiente do ponto de vista social.

O conceito estabelecido na Política Nacional de Meio Ambiente (PNMA) merece crítica, pois, como se pode perceber, o seu conteúdo não está voltado para um aspecto fundamental do problema ambiental, que é, exatamente 0 aspecto humano. A definição legal considera o ambiente do ponto de vista puramente biológico e não do ponto de vista social que, no caso é fundamental (ANTUNES, 2013, p. 70).

Édis Milaré também considera o ser humano parte integrante do mundo natural, aspecto omitido pela Lei 6.938/81.

\begin{abstract}
Assim, tanto a Lei 6.938/81 quanto a Lei Maior omitem-se sobre o aspecto essencial de que o ser humano, considerado como indivíduo ou como coletividade, é parte integrante do mundo natural e, por conseguinte, do meio ambiente. Essa omissão pode levar facilmente à ideia de que o ambiente é algo extrínseco e exterior à sociedade humana, confundindo-o, então, com seus componentes físicos e biológicos a abióticos, ou com recursos naturais e ecossistemas (MILARÉ, 2013, p. 139).
\end{abstract}

Destarte, Milaré define meio ambiente numa concepção ampla: "o meio ambiente abrange toda a natureza original (natural) e artificial, assim como os bens culturais correlatos". Chama a atenção ainda o autor para o "fator relações", essencial na constituição do meio ambiente pois "o meio ambiente é precisamente o resultado destas relações". Citando José Afonso da Silva, diz que o "meio ambiente seria a interação do conjunto de elementos naturais, artificiais e culturais que propiciem o desenvolvimento equilibrado da vida em todas as suas formas" (MILARÉ, 2013, p. 136).

Para Paulo de Bessa Antunes, meio ambiente "é a natureza mais a atividade antrópica, mais modificações produzidas pelo Ser Humano sobre o meio físico onde 
retira o seu sustento" (ANTUNES, 2013, p. 7). Elaborando mais o conceito, Antunes chega a seguinte definição:

meio ambiente compreende o humano como parte de um conjunto de relações econômicas, sociais e políticas que se constroem a partir da apropriação dos bens naturais que, por serem submetidos à influência humana, transformam-se em recursos essenciais para a vida humana em quaisquer aspectos (ANTUNES, 2013, p. 10).

\subsubsection{Processos ecológicos essenciais}

Um segundo conceito importante no Direito Ambiental é o conceito de processos ecológicos essenciais, expressão usada na Constituição Federal de 1988 (art. 225, inciso II).

Segundo José Afonso da Silva, a expressão significa "regenerar e proteger os solos, o ar atmosférico (...) defender a qualidade das águas, o patrimônio florestal (SILVA, 2009, p. 91).

Para Sirvinskas (2016, p. 165), processos ecológicos essenciais é um conceito "eminentemente ecológico", devendo-se preservar e restaurar não somente um dos recursos naturais, "isoladamente, na área degradada, mas todos os elementos bióticos e, abióticos que se relacionam entre si (física, química e biologicamente)". Assim, "para proteger a água, por exemplo, deve-se proteger o solo, o ar atmosférico, a flora, a fauna, enfim, todos os recursos naturais existentes na bacia hidrográfica e em torno dela".

Paulo de Bessa Antunes, por sua vez, ao discutir o termo constitucional assevera: "o que me parece é que o constituinte pretendeu resguardar uma estrutura natural mínima capaz de assegurar a reprodução e o desenvolvimento de determinados padrões de ecossistema". Interessante notar que o autor, logo em seguida, afirma que os processos ecológicos não essenciais do ponto de vista científico "estão a princípio, excluídos da proteção ambiental" (ANTUNES, 2013, p. 96).

Quando Édis Milaré traz uma listagem exemplificativa do que "podemos considerar como processos ecológicos fundamentais" enumera:

Fixação, transformação, transporte e utilização de energia; produção, transporte, transformação e utilização de matérias várias; biodegradação, condições e qualidades naturais; propagação e aperfeiçoamento das formas de vida num sentido evolutivo e de seleção natural; e num sentido mais 
amplo, o estabelecimento de condições adequadas à perpetuação e ao aperfeiçoamento da espécie humana (MILARÉ, 2013, p. 175).

\subsubsection{Ecossistema}

Processos ecológicos essenciais estão associados, na Constituição Federal de 88, ao conceito de ecossistema (art. 225, § I, inciso I).

Consoante Sirvinskas (2016), é a ecologia que nos fornece o conceito de ecossistema. $\mathrm{O}$ autor diz que ecossistema:

pode ser considerado como o conjunto de elementos bióticos (flora, fauna, micro-organismos) que interage com outros elementos abióticos (água, energia solar, solo, minérios etc.), dando sustentabilidade ao meio ambiente. Engloba o lugar (biótopo) e o agrupamento de seres vivos (biocenose) (SIRVINSKAS, 2016, p. 166).

José Afonso da Silva, citando Roger Dajoz, define

A biocenose e seu biótopo constituem, portanto, dois elementos inseparáveis que reagem um sobre o outro para produzir um sistema mais ou menos estável que recebe o nome de ecossistema. Ecossistemas são, pois, como já dissemos antes, sistemas de plantas, animais e microrganismos interagindo com elementos inanimados do seu meio (DAJOZ, 1973 apud SILVA, 2009, p. 92-3) ${ }^{16}$.

Paulo de Bessa Antunes sintetiza ecossistema como um: "conjunto de relacionamentos mútuos entre determinado meio ambiente e a flora, a fauna, e os microrganismos que nele habitam, e que incluem os fatores de equilíbrio geológico, atmosférico, meteorológico e biológico" (ANTUNES, 2013, p. 607-8).

\subsubsection{Equilíbrio ecológico}

Além de meio ambiente, processos ecológicos essenciais e ecossistema, um quarto conceito, o de equilíbrio ecológico, também expressão constitucional (art. 225, caput), define-se em consonância com os termos anteriores.

Machado limita-se a definir equilíbrio ecológico citando um dicionário de Geografia $^{17}$, segundo o qual equilíbrio ecológico:

\footnotetext{
${ }^{16}$ DAJOZ, R. Ecologia Geral. 2 ed. São Paulo: Vozes/Edusp, 1973.

${ }^{17}$ GIOVANETTI, Gilberto; LACERDA, Madalena. Melhoramentos Dicionário de Geografia. São Paulo: Melhoramentos, 1996.
} 
é o estado de equilíbrio entre os diversos fatores que formam o ecossistema ou habitat, suas cadeias tróficas, vegetação, clima, micro-organismos, solo, ar, água, que pode ser desestabilizado pela ação humana, seja por poluição ambiental, por eliminação ou introdução de espécies animais e vegetais (MACHADO, 2010, p. 553).

Na mesma direção, diz Édis Milaré: "Diz-se que um ambiente encontra-se equilibrado quando a pressão do meio regula e mantém a biota, mediante o fluxo de matéria, energia e informações genéticas" (MILARÉ, 2013, p. 553).

Por seu turno, Luís Paulo Sirvinskas assevera: "o equilíbrio ecológico não significa a inalterabilidade das condições naturais. Busca-se, no entanto, a harmonia ou a proporção e a sanidade entre os vários bens que compõem a ecologia (populações, comunidades, ecossistemas e biosfera)" (SIRVINSKAS, 2016, p. 162). E mais:

é bom ressaltar que equilíbrio ecológico não se confunde com sociedade ambientalmente equilibrada (art. 5으, V, da Lei n 9.795/99); o primeiro referese aos aspectos do meio ambiente natural, cultural, artificial e do trabalho; já o segundo descreve as cidades como sociedades urbanas ambientalmente equilibradas, no sentido de sociedades urbanas sustentáveis (SIRVINSKAS, 2016, p. 162).

\subsubsection{Poluição}

O conceito de poluição, segundo Wainer (1999), como visto anteriormente, aparece já no século XVII no Código Filipino, Título LXXXVIII, § 7ํ․ Posteriormente, é só o Código das Águas de 1934 que volta a falar em poluição, culminando com a definição trazida pela Lei 6.938 de 1981 (Quadro 3).

A doutrina, como dito, não trabalha demoradamente o conceito, limitando-se às definições legais.

\section{Quadro 3 - Conceito de Poluição na Legislação Nacional}

\begin{tabular}{|c|c|c|c|c|c|}
\hline LEI / DECRETO & ANO & \multicolumn{1}{c}{ ARTIGO } \\
\hline Decreto 24.643 & 1934 & $\begin{array}{l}\text { Art. 98: São expressamente proibidas construções capazes de poluir ou inutilizar } \\
\text { para o uso ordinário a água do poço ou nascente alheia, a elas preexistentes. } \\
\text { Art. 109: A ninguém é lícito conspurcar ou contaminar as águas que não } \\
\text { consome, com prejuízo de terceiros. }\end{array}$ \\
\hline Decreto-lei 50.877 & 1961 & $\begin{array}{l}\text { Art. 3ㅇ. Para os efeitos deste Decreto, considera-se "poluição" qualquer alteração } \\
\text { das propriedades físicas, químicas e biológicas das águas, que possa importar } \\
\text { em prejuízo à saúde, à segurança e ao bem-estar das populações e ainda } \\
\text { comprometer a sua utilização para fins agrícolas, industriais, comerciais, } \\
\text { recreativos e, principalmente, a existência normal da fauna aquática. }\end{array}$ \\
\hline
\end{tabular}


(continuação)

\begin{tabular}{|c|c|c|}
\hline LEI / DECRETO & ANO & ARTIGO \\
\hline Decreto-lei 221 & 1967 & $\begin{array}{l}\text { Art. 37: Os efluentes das redes de esgotos e os resíduos líquidos ou sólidos das } \\
\text { indústrias somente poderão ser lançados às águas, quando não as tornarem } \\
\text { poluídas. } \\
\text { § 1o: Considera-se poluição qualquer alteração das propriedades físicas, } \\
\text { químicas ou biológicas das águas, que possa constituir prejuízo, direta ou } \\
\text { indiretamente, à fauna e à flora aquática. }\end{array}$ \\
\hline Decreto-lei 303 & 1967 & $\begin{array}{l}\text { Art. 1:: Para as finalidades deste decreto-lei, denomina-se poluição qualquer } \\
\text { alteração das propriedades físicas, químicas ou biológicas do meio ambiente } \\
\text { (solo, água e ar), causada por qualquer substância sólida líquida, gasosa ou em } \\
\text { qualquer estado da matéria, que, direta ou indiretamente. }\end{array}$ \\
\hline Decreto 73.030 & 1973 & $\begin{array}{l}\text { Art. 13: No âmbito de suas atribuições, a SEMA dará prioridade, nos exercícios } \\
\text { de } 1973 \text { e 1974, aos estudos, proposições e ações relacionadas com a poluição } \\
\text { hídrica. } \\
\S 1^{\circ} \text { - Para os efeitos previstos neste artigo, a SEMA adotará diretrizes e critérios } \\
\text { que assegurem a defesa contra a poluição das águas, entendida como qualquer } \\
\text { alteração de suas propriedades físicas, químicas ou biológicas, que possa } \\
\text { importar em prejuízo à saúde, à segurança e ao bem-estar das populações, } \\
\text { causar dano à flora e à fauna, ou comprometer o seu uso para fins sociais e } \\
\text { econômicos. }\end{array}$ \\
\hline Lei 6.938 & 1981 & $\begin{array}{l}\text { Art. } 3^{\circ} \text { - Para os fins previstos nesta Lei, entende-se por: } \\
\text { III - poluição, a degradação da qualidade ambiental resultante de atividades que } \\
\text { direta ou indiretamente: } \\
\text { a) prejudiquem a saúde, a segurança e o bem-estar da população; } \\
\text { b) criem condições adversas às atividades sociais e econômicas; } \\
\text { c) afetem desfavoravelmente a biota; } \\
\text { d) afetem as condições estéticas ou sanitárias do meio ambiente; } \\
\text { e) lancem matérias ou energia em desacordo com os padrões ambientais } \\
\text { estabelecidos; }\end{array}$ \\
\hline Lei 9.605 & 1998 & $\begin{array}{l}\text { Art. 54: Causar poluição de qualquer natureza em níveis tais que resultem ou } \\
\text { possam resultar em danos à saúde humana, ou que provoquem a mortandade de } \\
\text { animais ou a destruição significativa da flora. }\end{array}$ \\
\hline
\end{tabular}

Fonte: Elaborado pelo autor com base nos dados da pesquisa, 2015.

Descrevendo resumidamente, as primeiras normas sobre poluição falam das propriedades físicas, químicas e biológicas do meio ambiente, sobretudo dos recursos hídricos, enquanto que, a partir da década de 70, os aspectos sociais, econômicos estéticos e sanitários são incorporados à noção de poluição.

\subsubsection{Diversidade biológica e recurso ambiental}

Diversidade biológica é definida na Lei que institui o Sistema Nacional de Unidades de Conservação da Natureza (Lei 9.985/2000). Pela norma, diversidade biológica é "a variedade de organismos vivos de todas as origens, compreendendo, dentre outros, os ecossistemas terrestres, marinhos e outros ecossistemas aquáticos 
e complexos ecológicos de que fazem parte; compreendendo ainda a diversidade dentro de espécies, entre espécies e de ecossistemas" (art. $2^{\circ}$, inciso III).

A Lei 9.985/2000 conceitua igualmente recurso ambiental como "a atmosfera, as águas interiores, superficiais e subterrâneas, os estuários, o mar territorial, o solo, os elementos da biosfera, a fauna e a flora" (art. $2^{\circ}$, inciso IV).

\subsubsection{Espaços territoriais especialmente protegidos}

Os demais termos presentes na Lei 9.985/2000 não definem, exatamente, o conceito de meio ambiente, mas são com ele correlatos, como ilustram os conceitos de unidade de conservação, a definição de conservação, preservação, recuperação e restauração da natureza (quadro 4). As unidades de conservação são espécies do gênero "espaços territoriais e seus componentes a serem especialmente protegidos", expressão empregada na Constituição Federal (art. 225, § 1ำ, inciso III). A doutrina de Direito Ambiental interpreta o termo da seguinte forma:

\section{Quadro 4 - Definições Presentes na Lei 9.985/2000}

TERMO

Unidade de Conservação

Conservação da Natureza

Diversidade Biológica

Recurso ambiental

Preservação

\section{DEFINIÇÃO}

Espaço territorial e seus recursos ambientais, incluindo as águas jurisdicionais, com características naturais relevantes, legalmente instituído pelo Poder Público, com objetivos de conservação e limites definidos, sob regime especial de administração, ao qual se aplicam garantias adequadas de proteção (art. $2^{\circ}$, inciso I)

O manejo do uso humano da natureza, compreendendo a preservação, a manutenção, a utilização sustentável, a restauração e a recuperação do ambiente natural, para que possa produzir o maior benefício, em bases sustentáveis, às atuais gerações, mantendo seu potencial de satisfazer as necessidades e aspirações das gerações futuras, e garantindo a sobrevivência dos seres vivos em geral (art. $2^{\circ}$, inciso II)

A variabilidade de organismos vivos de todas as origens, compreendendo, dentre outros, os ecossistemas terrestres, marinhos e outros ecossistemas aquáticos e os complexos ecológicos de que fazem parte; compreendendo ainda a diversidade dentro de espécies, entre espécies e de ecossistemas (art. 2ㅜ inciso III)

A atmosfera, as águas interiores, superficiais e subterrâneas, os estuários, o mar territorial, o solo, o subsolo, os elementos da biosfera, a fauna e a flora (art. 2ㅜㄹ inciso IV)

Conjunto de métodos, procedimentos e políticas que visem a proteção a longo prazo das espécies, habitats e ecossistemas, além da manutenção dos processos ecológicos, prevenindo a simplificação dos sistemas naturais (art. $2^{\circ}$, inciso $\mathrm{V}$ ) 
(continuação)

TERMO

Manejo

Recuperação

Restauração

\section{DEFINIÇÃO}

Todo e qualquer procedimento que vise assegurar a conservação da diversidade biológica e dos ecossistemas (art. $2^{\circ}$, inciso VIII)

Restituição de um ecossistema ou de uma população silvestre degradada a uma condição não degradada, que pode ser diferente de sua condição original (art. $2^{\circ}$, inciso XIII)

Restituição de um ecossistema ou de uma população silvestre degradada o mais próximo possível da sua condição original (art. $2^{\circ}$, inciso XIV)

Fonte: Elaborado pelo autor com base nos dados da pesquisa, 2015.

Para José Afonso da Silva, os espaços territoriais especialmente protegidos (ETEPs) "em sentido ecológico, referem-se, na verdade, a ecossistemas. Se são dignos de proteção especial é porque são áreas representativas dos ecossistemas". Assim, os ETEPs possuem regime jurídico especial "quanto à modificabilidade e quanto à fruição" em vista da relevância dos atributos naturais de que se revestem, postulando proteção especial" (SILVA, 2009, p. 231).

\begin{abstract}
Espaços Territoriais Especialmente Protegidos são áreas geográficas públicas ou privadas (porção do território nacional) dotadas de atributos ambientais que requeiram sua sujeição, pela lei, a um regime jurídico de interesse público que implique sua relativa imodificabilidade e sua utilização sustentada, tendo em vista a preservação e proteção de integridade de amostras de toda a diversidade de ecossistema, a proteção ao processo evolutivo das espécies, a preservação e proteção dos recursos naturais (SILVA, 2009, p. 233).
\end{abstract}

À medida que os atributos das áreas protegidas não são os mesmos, dividem-se as ETEPs em territórios espécies que permitam a proteção de características mais particulares de cada área, a exemplo das unidades de conservação (UC), das áreas de preservação permanente (APPs) e das reservas legais $(R L)$.

Sobre Unidades de Conservação, Sirvinskas cita Motauri Ciocchetti de Souza, para quem o escopo das Unidades de Conservação é "o de proteger e preservar os ecossistemas em seus estados naturais e primitivos ou recuperá-los" (SOUZA, 1996 apud SIRVINSKAS, 2016, p. 563). Sirvinskas completa: "Unidade de Conservação é o espaço territorial e seus recursos ambientais, incluindo as águas jurisdicionais, com características naturais relevantes, legalmente constituídas (...)" (SIRVINSKAS, 2016, p. 563).

São consideradas, no total, doze unidades no Brasil, tanto as de proteção integral quanto as de uso sustentável (quadro 5). 


\section{Quadro 5 - Espécies de Unidades de Conservação Conforme Lei № 9.985/2000 \\ PROTEÇÃO INTEGRAL \\ OBJETIVO}

Estação Ecológica

Monumento Natural

Parque Nacional

Refúgio da Vida Silvestre

Reserva Biológica

USO SUSTENTÁVEL

Floresta Nacional

\begin{tabular}{|c|}
\hline Reserva Extrativista \\
\hline Reserva Particular do \\
Patrimônio Natural \\
\hline Reserva de \\
Desenvolvimento \\
Sustentável
\end{tabular}

Reserva da Fauna

Área de Proteção Ambiental

Áreas de Relevante Interesse Ecológico
Preservação da natureza e a realização de pesquisas científicas (art. 9)

Preservar sítios naturais raros, singulares ou de grande beleza cênica (art. 12)

Preservação de ecossistemas naturais de grande relevância ecológica e beleza cênica, possibilitando a realização de pesquisas científicas e o desenvolvimento de atividades de educação e interpretação ambiental, de recreação em contato com a natureza e de turismo ecológico (art. 11)

Proteger ambientes naturais onde se asseguram condições para a existência ou reprodução de espécies ou comunidades da flora local e da fauna residente ou migratória (art. 13)

Preservação integral da biota e demais atributos naturais existentes em seus limites, sem interferência humana direta ou modificações ambientais, excetuando-se as medidas de recuperação de seus ecossistemas alterados e as ações de manejo necessárias para recuperar e preservar o equilíbrio natural, a diversidade biológica e os processos ecológicos naturais (art. 10)

Área com cobertura florestal de espécies predominantemente nativas e tem como objetivo básico o uso múltiplo sustentável dos recursos florestais e a pesquisa científica, com ênfase em métodos para exploração sustentável de florestas nativas (art. 17)

Área utilizada por populações extrativistas tradicionais, cuja subsistência baseia-se no extrativismo e, complementarmente, na agricultura de subsistência e na criação de animais de pequeno porte, e tem como objetivos básicos proteger os meios de vida e a cultura dessas populações, e assegurar o uso sustentável dos recursos naturais da unidade (art. 18)

Área privada, gravada com perpetuidade, com o objetivo de conservar a diversidade biológica (art. 21)

Área natural que abriga populações tradicionais, cuja existência baseia-se em sistemas sustentáveis de exploração dos recursos naturais, desenvolvidos ao longo de gerações e adaptados às condições ecológicas locais e que desempenham um papel fundamental na proteção da natureza e na manutenção da diversidade biológica (art. 20)

Área natural com populações animais de espécies nativas, terrestres ou aquáticas, residentes ou migratórias, adequadas para estudos técnico-científicos sobre o manejo econômico sustentável de recursos faunísticos (art. 19)

Área em geral extensa, com um certo grau de ocupação humana, dotada de atributos abióticos, bióticos, estéticos ou culturais especialmente importantes para a qualidade de vida e o bem-estar das populações humanas, e tem como objetivos básicos proteger a diversidade biológica, disciplinar o processo de ocupação e assegurar a sustentabilidade do uso dos recursos naturais (art. 15)

Área em geral de pequena extensão, com pouca ou nenhuma ocupação humana, com características naturais extraordinárias ou que abriga exemplares raros da biota regional, e tem como objetivo manter os ecossistemas naturais de importância regional ou local e regular o uso admissível dessas áreas, de modo a compatibilizá-lo com os objetivos de conservação da natureza (art. 16)

Fonte: Elaborado pelo autor com base nos dados da pesquisa, 2015. 


\subsubsection{Dano ambiental: patrimonial e extrapatrimonial}

Dano ambiental é um dano que se produz ao meio ambiente, podendo repercutir no sujeito de direito, individual ou coletivamente considerado. Ele possui uma dupla ocorrência, ou seja, o dano ao meio ambiente enquanto dano na esfera patrimonial e o dano na esfera extrapatrimonial.

Dano, nas palavras de Sirvinskas (2016), é toda lesão a um bem jurídico tutelado. Já dano ambiental é entendido como "toda agressão contra o meio causada por atividade econômica potencialmente poluidora, por ato comissivo praticado por qualquer pessoa ou por omissão voluntária decorrente de negligência" (SIRVINSKAS, 2016, p. 265).

Paulo Affonso Leme Machado fala em dano ecológico, buscando o conceito no Direito comparado, mas no decorrer das explanações intercala a palavra ecológico com meio ambiente. "Todas as alterações ecológicas constituem dano ecológico reparável?", pergunta-se o autor ao tratar do Direito brasileiro. "Seria excessivo dizer que todas as alterações no meio ambiente vão ocasionar um prejuízo, pois dessa forma estaríamos negando a possibilidade de mudança e de inovação, isto é, estaríamos entendendo que o estado adequado do meio ambiente é o imobilismo, o que é irreal" (MACHADO, 2010, p. 359).

José Afonso da Silva também fala em dano ecológico e o conceitua como sendo "qualquer lesão ao meio ambiente" (2009, p. 302), cabendo lembrar que para o autor, o conceito legal de meio ambiente se restringe ao meio ambiente natural.

Porém, o dano ambiental não se confunde com os bens materiais ecológicos, quer dizer, não se resume à lesão ocasionada aos elementos que compõem o meio ambiente. De fato, pondera Bessa Antunes:

\footnotetext{
Embora uma árvore seja um recurso ambiental, não é o meio ambiente. Dano ambiental, portanto, é a ação ou omissão que prejudique as diversas condições, leis, influências e interações de ordem física, química e biológica que permita, abrigue e reja a vida, em quaisquer de suas formas (...). O bem jurídico meio ambiente não é um simples somatório da flora e fauna, de recursos hídricos e recursos minerais. Ele resulta do somatório de todos os componentes que, isoladamente, podem ser identificados, tais como florestas, animais, ar etc. Esse conjunto de bens adquire particularidade jurídica que é derivada da própria interação ecológica de seus elementos componentes (ANTUNES, 2013, p. 539).
}

Conforme Antunes, o bem jurídico meio ambiente não é um bem material em si, mas um bem abstrato resultante da interação do conjunto de seus componentes. 
Nisto concorda com Dionísio Renz Birnfeld, pois "quando são protegidos esses bens, o que se busca não é sua defesa, em si, mas a sua defesa como elementos indispensáveis à proteção do meio ambiente como bem imaterial, que é objeto último visado pelo legislador", afirma Birnfeld (2009, p. 46). Destarte, o meio ambiente é um bem autônomo, inconfundível com os elementos que o constituem.

$\mathrm{Na}$ proposta de classificação do dano ambiental, Leite e Ayala (2015) diferenciam o dano ambiental quanto à amplitude do bem protegido em dano ecológico puro e o dano ambiental lato sensu. O primeiro, numa concepção restrita, está relacionado aos componentes naturais do ecossistema enquanto o segundo, num significado mais amplo, concerne "aos interesses difusos da coletividade", abrangendo todos os elementos do meio inclusive o patrimônio cultural (LEITE \& AYALA, 2015, p. 105).

Ainda segundo a classificação dos autores, o dano ambiental, quanto à sua extensão, pode dar-se como dano patrimonial ambiental e dano extrapatrimonial ou moral ambiental. $\mathrm{O}$ dano patrimonial ambiental relaciona-se ao bem ambiental lesado ao passo que o dano moral ambiental insere-se na ordem dos sentimentos vividos pelo indivíduo ou pela coletividade.

Lecionam Leite e Ayala:

\begin{abstract}
O dano ambiental, por sua vez, constitui uma expressão ambivalente que designa, certas vezes, alterações nocivas ao meio ambiente e outras, ainda, os efeitos que de tal alteração provoca na saúde das pessoas e em seus interesses. Dano ambiental significa, em uma primeira acepção, uma alteração indesejável ao conjunto de elementos chamados meio ambiente, como por exemplo, a poluição atmosférica; seria, assim a lesão ao Direito fundamental que todos têm de gozar e aproveitar do meio ambiente apropriado. Contudo, em sua segunda conceituação, dano ambiental engloba os efeitos que esta modificação gera na saúde das pessoas e em seus interesses (LEITE \& AYALA, 2015, p. 104).
\end{abstract}

Dionísio Renz Birnfeld afirma que "o dano ambiental possui uma dimensão material consistente na perda ou diminuição das características essenciais dos sistemas ecológicos e uma dimensão imaterial que afeta o interesse difuso e se relaciona ao valor de existência dos bens ambientais" (BIRNFELD, 2009, p. 50).

$\mathrm{Na}$ doutrina de Édis Milaré, dano ambiental patrimonial é conceituado da seguinte forma:

Dano ambiental patrimonial é aquele que repercute sobre o próprio bem ambiental, isto é, o meio ambiente ecologicamente equilibrado, relacionandose à sua possível restituição ao status quo ante compensação ou indenização. A diminuição da qualidade de vida da população, o 
desequilíbrio ecológico, o comprometimento de um determinado espaço protegido, os incômodos físicos ou lesões à saúde e tantos outros constituem lesões ao patrimônio ambiental (MILARÉ, 2013, p. 323).

Dano ambiental extrapatrimonial, por sua vez, é assim conceituado:

O dano moral extrapatrimonial, previsto no art. 1으, caput, da Lei 7.347 , caracteriza-se pela ofensa, devidamente evidenciada, ao sentimento difuso ou coletivo resultante da lesão ambiental patrimonial. Vale dizer, quando um dano patrimonial é cometido, a ocorrência de relevante sentimento coletivo de dor, sofrimento e/ou frustração resulta na configuração do dano ambiental extrapatrimonial ou moral (...). O dano moral ambiental, dessa forma, irá se contrapor ao dano ambiental material. Este afeta, por exemplo, a própria paisagem natural, ao passo que aquele se apresentará como um sentimento psicológico negativo junto à comunidade respectiva (MILARÉ, 2013, p. 323).

A extrapatrimonialidade do dano ambiental está ligada a sua imaterialidade, pois se vincula ao sentimento do indivíduo ou da comunidade.

José Augusto Delgado, ex-ministro do Superior Tribunal de Justiça (STJ), em artigo sobre a Responsabilidade Civil por Dano Ambiental Moral, transcreve variada doutrina nacional sobre o tema, sempre a destacar os valores culturais ligados aos componentes ambientais, como a qualidade ambiental e a qualidade de vida. Delgado cita, por exemplo, Talden Farias no sentido de que uma coisa é o dano material, outra "é o dano moral consistente na perda de valores ambientais pela coletividade" (DELGADO, 2008, p. 115). Noutra citação, é transcrito um trecho do artigo de Ana Maria Marchesam, Annelise Monteiro Steigleder e Sílvia Cappelli no qual asseveram:

No caso do dano ecológico, a primeira premissa é perceber que este dano não consiste apenas e tão-somente na lesão ao equilíbrio ecológico, afetando igualmente outros valores precípuos da coletividade a ele ligados, a saber: a qualidade de vida e a saúde. Estes valores estão intimamente inter- relacionados, de modo que a agressão ao ambiente afeta diretamente a saúde e a qualidade de vida da comunidade. Portanto, as lesões a direitos difusos e coletivos também poderão produzir danos morais, pois qualquer abalo no patrimônio moral da coletividade também merece reparação (MARCHESAM et al, 2006 apud DELGADO, 2008, p. 99).

Segundo José Luiz Baracho Júnior:

O dano ambiental pode ser compreendido como sendo o prejuízo causado a todos os recursos ambientais indispensáveis para a garantia de um meio ecologicamente equilibrado, provocando a degradação e, consequentemente, o desequilíbrio ecológico (...). O dano moral ambiental, por sua vez, tem ligação com todo prejuízo que não seja econômico, causado à coletividade, em razão da lesão ao meio ambiente (BARACHO JÚNIOR, 2000 apud DELGADO, 2008, p. 108-9). 
No mesmo sentido caminha Rogério Tadeu Romano quando diz: "Aparecerá o dano moral quando além da repercussão física no patrimônio ambiental houver ofensa ao sentimento difuso ou coletivo (...). Há ofensa ambiental quando for identificada dor, sofrimento ou desgosto da comunidade" (ROMANO, s, d., apud DELGADO, 2008, p. 119).

O dano extrapatrimonial ambiental, contudo, consoante doutrina de Leite e Ayala (2015) não prende-se somente ao caráter subjetivo da pessoa ou comunidade atingida, sendo subdividida também quanto ao seu aspecto objetivo. Esclarecem os autores:

\begin{abstract}
Pode ser configurada uma subdivisão do dano extrapatrimonial em aspecto subjetivo e/ou objetivo levando em conta o sujeito lesado. De um lado, observa-se o seu caráter subjetivo, quando importe em sofrimento psíquico, de afeição, ou físico, como por exemplo, a perda de um ascendente ou descendente. Na hipótese da lesão ambiental, esta se configura subjetiva quando, em consequência desta, a pessoa física venha a falecer ou sofrer deformidades permanentes ou temporais, trazendo sofrimento de ordem direta e interna. Por outro lado, tem-se como dano extrapatrimonial objetivo aquele que lesa interesse que não repercutem na esfera íntima da vítima e dizem respeito a uma dimensão moral da pessoa no meio social em que vive, envolvendo sua imagem. Isto é, aquele que atinge valores imateriais da pessoa ou da coletividade, como, por exemplo, ao degradar o meio ambiente ecologicamente equilibrado ou a qualidade de vida, como um Direito intergeracional, fundamental e intercomunitário (LEITE \& AYALA, 2015, p. 276).
\end{abstract}

\title{
5.2.9 Paisagem
}

A proteção legal da paisagem no Brasil consta, pelo menos, desde a Constituição Federal de 1937 e, especialmente, a partir do Decreto Lei ํo 25 de 1937.

A Constituição de 37 , no seu artigo 134, colocava as paisagens ou os locais particularmente dotados pela natureza sob proteção e cuidados especiais da Nação, dos Estados e dos Municípios, enquanto o Decreto ํo 25 no artigo 1으, §2º equiparava as paisagens de feição notável, dotados pela natureza ou agenciados pela indústria humana, aos bens constituintes do patrimônio histórico e artístico nacional.

Apesar das Constituições posteriores manterem a proteção às paisagens em seus textos, ressente-se ainda hoje de uma definição legal em âmbito nacional. A exceção fica por conta da Portaria no 127 do Instituto do Patrimônio Histórico e Artístico Nacional (IPHAN) e, além da esfera legal, por conta das doutrinas de José 
Afonso da Silva, Édis Milaré, podendo mencionar-se, também, a tese de doutorado de Maraluce Maria Custódio.

A Portaria no 127 de 2009 do IPHAN dispõe sobre a chancela da paisagem cultural brasileira, conceituando-a como "uma porção peculiar do território nacional, representativa do processo de interação do homem com o meio natural, à qual a vida e a ciência humana imprimem marcas ou atribuem valores" (art.1). Mas, além de restringir a definição desta à "paisagem cultural brasileira", o IPHAN não é o órgão mais competente para estabelecer uma apropriada definição legal de forma a vincular outras esferas do poder público.

$\mathrm{Na}$ doutrina, José Afonso da Silva centra-se na definição de paisagem urbana $^{18}$, a qual constitui "a roupagem da cidade" a revelar-se nos "elementos formas da cidade". Para o autor, os componentes fundamentais da paisagem "exteriorizam-se no traçado urbano, nas áreas verdes e outras formas de arvoredo, nas fachadas arquitetônicas e no mobiliário urbano" (SILVA, 2010, p. 302).

Já Édis Milaré conceitua paisagem como "uma realidade biológica, uma realidade físicoquímica, integradora da biota local (...) paisagem é uma síntese do solo, do ar, da água, dos vegetais e, sem dúvida, também dos animais" (MILARÉ, 2013, p. 609-610).

Maraluce Maria Custódio, por último, no final de sua tese, propõe a seguinte definição de paisagem:

\begin{abstract}
A paisagem é um Direito de terceira geração basilar, integrado tanto pela criação, quanto pela proteção da estabilidade ou transformação física de seus elementos naturais e culturais, levando-se em conta as percepções de todos os grupos sociais, independentemente de raça, cor e classe, garantida, assim, sua mutabilidade e evolução. Para isso, a paisagem deve ser construída possibilitando-se a participação de todos, ainda que através de associações que representem os diversos interesses da comunidade, de forma que expressem em debate público seus anseios. Em sendo um bem comum, sua proteção é primordial para garantia da paz social e da proteção de identidades - tanto local, quanto nacional - e conhecimentos tradicionais nos âmbitos da federação brasileira, das presentes e futuras gerações (CUSTÓDIO, 2012, p. 321-322).
\end{abstract}

Apesar destas definições, o conceito não está consolidado legalmente e a proteção legal da paisagem fica, então, sujeita a interpretações da doutrina jurídica e da jurisprudência dos Tribunais. Para Custódio: "não existe um conceito jurídico de paisagem no Brasil, o que dificulta sua percepção pela população em geral e permite

18 Em outra obra, José Afonso da Silva cita o termo paisagem dentro de um contexto de análise do meio ambiente natural, mas não chega a elaborar uma definição. 
ao poder público ser arbitrário em suas decisões, definindo ele próprio o conceito e, portanto, a referência e a delimitação de seu referente" (CUSTÓDIO, 2012, p. 267). 


\title{
6 OS PROCESSOS JUDICIAIS
}

Caracterizar como a doutrina compreende o meio ambiente traz um aspecto importante do Direito Ambiental, mas não revela todo seu conteúdo. A doutrina é apenas uma face do problema, tendo em vista que a jurisprudência dos tribunais conforma igualmente um entendimento jurídico do meio ambiente.

Efetivamente, a interpretação e aplicação dos conceitos e definições ambientais são também operadas no âmbito dos tribunais, por juízes e advogados. O exemplo abaixo nos mostra isso mais de perto.

Num processo que correu no Tribunal do Estado de Minas Gerais (MINAS GERAIS, Apelação Criminal oㅜ 1.0879.08.000656-9/001, 2014a), assim se manifestou o juiz na decisão de mérito sobre o conceito de floresta:

\begin{abstract}
Conquanto haja prova suficiente da autoria deletiva, demonstrando robustamente que foi o apelante quem ordenou o seu empregado que ateasse fogo na área de preservação permanente, entendo não haver nos autos prova suficiente de que a área de vegetação queimada tratava-se de 'floresta', sendo, portanto, atípica a conduta (...)

A análise do referido tipo penal revela o elemento normativo 'floresta', sendo este, ainda, o objeto material da conduta incriminada. Embora a lei 9.605/1998 não defina o significado de 'floresta', a doutrina e a jurisprudência do Superior Tribunal de Justiça a conceituam como vegetação cerrada, composta de árvores de grande porte, que cobre grande extensão de terra (...)

Tem-se, pois, que a prova colecionada aos autos, assim como a narrativa dos fatos na denúncia, despreocupada com a definição jurídica de 'floresta', não permite concluir com segurança que a ação de queimada da área de preservação permanente deu-se sobre o elemento normativo do tipo do artigo 38 da Lei 9.605/1998, nada exsurgindo dos autos que permita a conclusão segura de que a vegetação queimada era de grande porte, densa e ocupada de grande extensão de terra (MINAS GERAIS, Apelação Criminal no $1.0879 .08 .000656-9 / 001,2014 a$, p. 6-8).
\end{abstract}

No mesmo Tribunal, um segundo juiz manifestou-se em sentido contrário, nos seguintes termos (MINAS GERAIS, Recurso em sentido estrito no 1.0702.09.598762$5 / 001,2010)$.

Todavia, "floresta de preservação permanente", como elementar típica do art. 38 da Lei de Crimes Ambientais, constitui um conceito complexo que não comporta uma análise superficial. Primeiramente, é preciso ressaltar que o tipo do art. 38 da Lei n. 9.605/98 não apresenta a melhor redação ao restringir o objeto da tutela ao termo "floresta" de preservação permanente, quando sabemos, por uma interpretação adequada e sistemática à luz das normas ambientais, que o objetivo da norma é proteger toda e qualquer vegetação existente em área de preservação permanente (...).

A lei [lei 4.771/65] é clara ao tutelar toda e qualquer vegetação existente na área de preservação permanente, o que não se adequa à restrição protetiva do tipo "floresta" contida no tipo do art. 38 da Lei n. 9.605/98. Apegar-se à 
literalidade do dispositivo é negar a importância da vegetação e do reflorestamento para a manutenção de um meio ambiente ecologicamente equilibrado (...).

Assim, é importante reconhecermos que o conceito legal de floresta de preservação permanente alcança toda a formação vegetal contida nesta área, e não somente aquela nativa e de grande porte arbóreo. A norma visa dissuadir e punir qualquer conduta humana contrária a tal escopo, e não só aquela dirigida à extração florestal massiva propriamente dita (MINAS GERAIS, Recurso em sentido estrito no $1.0702 .09 .598762-5 / 001,2010$, p. 5$6)$.

Nos trechos reproduzidos, o conceito de floresta é discutido e definido pelo magistrado, tornando-se base para a decisão de mérito da lide. No primeiro caso, uma interpretação restritiva de floresta fundamentou a decisão, enquanto, no segundo processo, uma interpretação extensiva e teleológica do conceito de floresta permitiu uma decisão em sentido contrário.

A caracterização do meio ambiente da forma como é interpretada no Direito Ambiental exige, portanto, pesquisas também nos processos existentes nos tribunais.

Conceitualmente, processo é "instrumento através do qual a jurisdição opera" (DINAMARCO et al, 2010, p. 301). Pelo processo, o Estado exerce o poder de jurisdição que tem no território, ou seja, o poder de "formular e fazer atuar praticamente a regra jurídica concretamente que, por força do direito vigente, disciplina determinada situação jurídica" (THEODORO JR., 2011, p. 46). Substituindo a justiça privada na resolução de conflitos, o Estado moderno assume a função jurisdicional, compondo o conflito de interesses dentro do processo, obedecendo a uma série coordenada de procedimentos para, no final, fazer valer a vontade da lei. No processo, o Estado compõe "a lide em juízo através de uma relação jurídica vinculativa de direito público" (THEODORO JR., 2011, p. 58).

O processo é método ou sistema de atuação, consoante Theodoro Júnior (2011); ele é composto pelos atos processuais ou procedimentos, que são "o meio extrínseco pelo qual se instaura, desenvolve-se e termina o processo; é a manifestação extrínseca deste, a sua realidade fenomenológica perceptível" (DINAMARCO, 2010, p. 301).

O processo tem início com o despacho da petição inicial pelo juiz. É na petição inicial que o autor demanda perante o Estado-juiz a prestação jurisdicional. É também na petição inicial que o autor descreve o fato material e os fundamentos jurídicos do pedido, isto é, o autor indica "o direito subjetivo que pretende exercitar 
contra o réu e apontar o fato de onde ele provém" (THEODORO JR., 2011, p. 358). Nas palavras de Luis Arlindo Feriani:

O autor deve ser preciso com relação aos fatos relevantes, que dizem respeito à questão jurídica que será objeto de decisão judicial (...). A fundamentação jurídica, que é diferente da legal, é obrigatória e refere-se à relação jurídica e o fato contrário do réu que está justificando a invocação da tutela do Estado-juiz (FERIANI, 2000, p. 196).

Sobre os fatos e os fundamentos jurídicos, aduz Cândido Rangel Dinamarco:

\begin{abstract}
Narrar fatos significa descrevê-los como faz um historiador. Descrevem-se os acontecimentos em si mesmos, em sua autoria e em suas circunstâncias de modo, lugar e tempo. Fatos descritos são segmentos da História, ou eventos da vida, aos quais o demandante atribui a eficácia de lhe conferir o direito alegado e a necessidade da tutela jurisdicional postulada. Das dimensões que tiverem dependerão os limites da sentença a ser proferida, a qual não pode apoiar-se em fatos não narrados (...). Fundamentos jurídicos constituem na demonstração de que os fatos narrados se enquadram em determinada categoria jurídica (...) e de que a sanção correspondente é aquela que o demandante pretende (DINAMARCO, 2005, p. 127).
\end{abstract}

Noutro extremo do processo encontra-se a sentença, que é ato do juiz mediante o qual o Estado cumpre sua função jurisdicional. É na sentença que se decide o mérito da ação e se põe termo a controvérsia ajuizada. A sentença marca o fim do processo. O conjunto de sentenças ditadas sobre o mesmo ponto, com interpretação uniforme do direito, forma a jurisprudência.

O processo tem, portanto, dentro do Direito Ambiental, papel relevante por revelar - e às vezes mesmo estabelecer conceitualmente - como o meio ambiente é interpretado e a sua consequente aplicação. Os processos têm o potencial de desvelar o meio ambiente da maneira como ele é narrado nos fundamentos de fato e sob quais princípios, conceitos e normas de direito ele é abrigado.

A tarefa de pesquisa de processos judiciais é, porém, custosa dada a quantidade de casos que vão à arbitragem da Justiça. A menos que se queira trabalhar com alguma situação concreta em particular, a escolha do tribunal, o tipo de processo, a forma de pesquisa do conteúdo são variáveis que dificultam uma sistematização mais rígida.

Não obstante, para pesquisar como meio ambiente é interpretado na jurisprudência dos tribunais em relação ao seu significado, tentamos primeiro pesquisar a ocorrência do termo paisagem (um dos elementos que compõem o meio ambiente). 
6.1 JURISPRUDÊNCIA SOBRE PAISAGEM: OCORRÊNCIA NOS TRIBUNAIS DE JUSTIÇA ESTADUAIS

Optamos por pesquisar o uso do termo paisagem como ocorre na jurisprudência dos Tribunais de Justiça estaduais e do Distrito Federal. A pesquisa foi realizada em outubro de 2014. A busca foi feita no site oficial de cada Tribunal estadual e do Distrito Federal: buscou-se a expressão "paisagem" no inteiro teor dos acórdãos presentes em todos os órgãos julgadores entre os anos de 1988 e 2015.

Apesar de uma necessária análise estatística dos resultados obtidos (o número de ocorrências em cada estado deve ser posto em relação ao número total de processos em cada tribunal) a pesquisa sobre o uso do termo paisagem expõe uma primeira situação quanto à ocorrência do uso do termo: algumas regiões apresentam ocorrência de uso bem maior em relação aos outros estados.

Quando se procura a palavra paisagem na jurisprudência dos Tribunais de Justiça, a região Sudeste aparece com maior número de processos, sendo seguido pela região Sul e Centro-Oeste respectivamente. Já as regiões Norte e Nordeste mostram baixa ocorrência do termo (Gráfico 1).

Gráfico 1 - Número de ocorrências do termo paisagem na jurisprudência dos Tribunais de Justiça estaduais por região

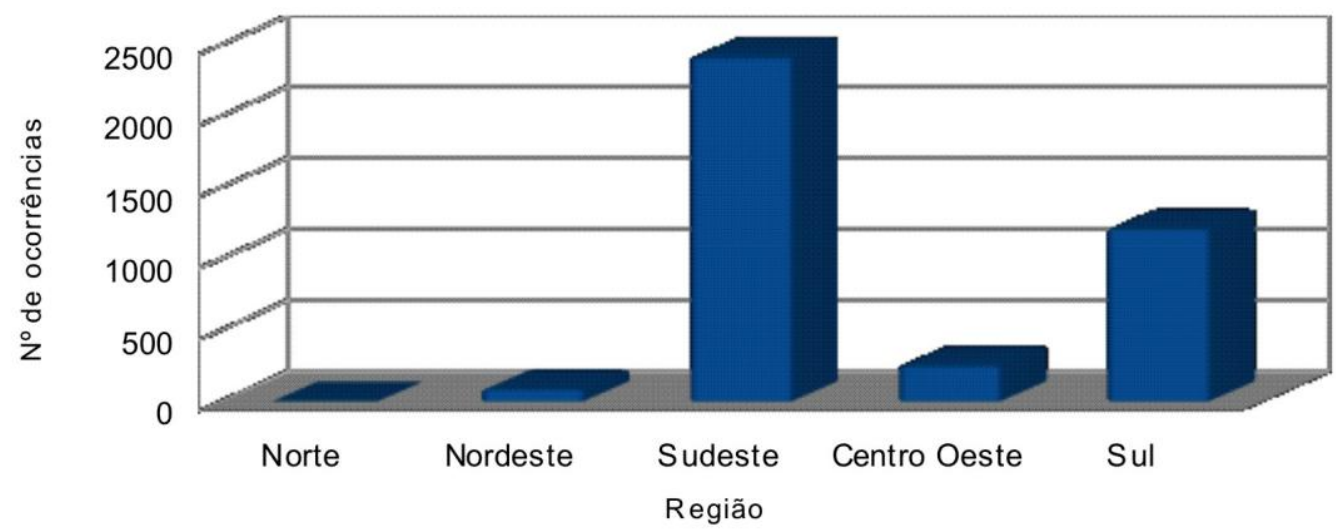

Fonte: Elaborado pelo autor com base nos dados da pesquisa.

Se discriminarmos a região Sudeste, porém, veremos alguns estados com número de ocorrências bem mais significativo que outros. No gráfico 2 , São Paulo é o estado onde o termo paisagem mais aparece como resultado da busca na 
jurisprudência, atingindo quase 1500 casos; Rio de Janeiro e Espírito Santo, por outro lado, não totalizam uma centena das ocorrências.

Gráfico 2 - Número de ocorrências do termo paisagem na jurisprudência dos Tribunais de Justiça dos estados da região Sudeste

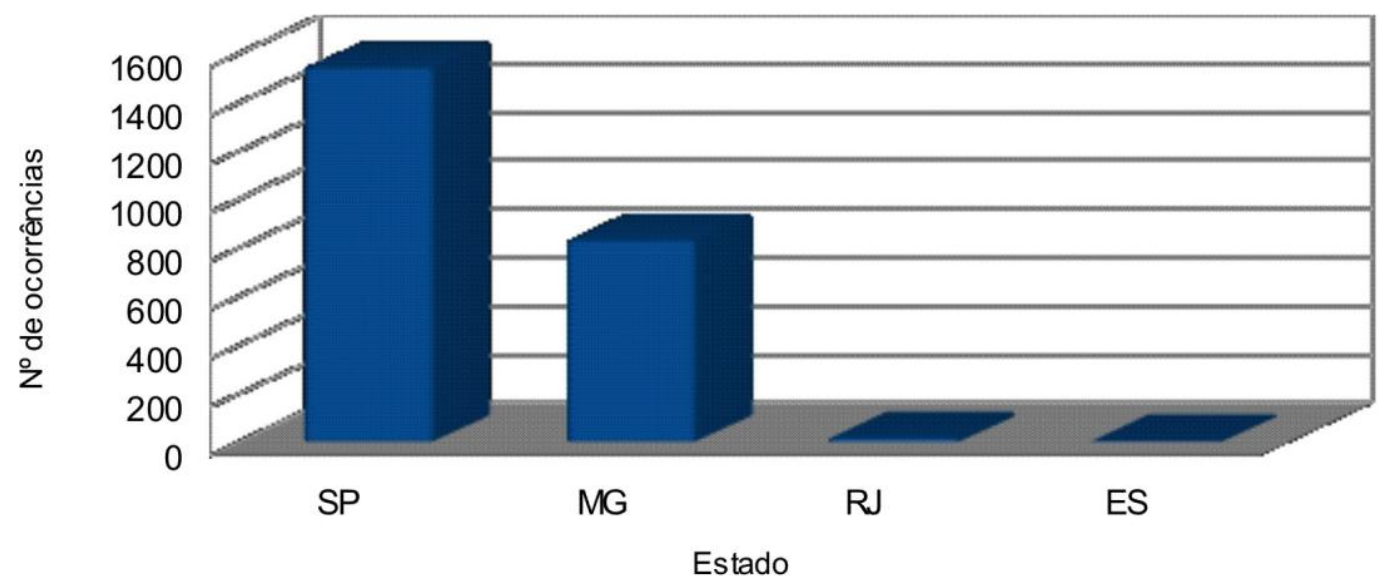

Fonte: Elaborado pelo autor com base nos dados da pesquisa.

Quem mais se aproxima de São Paulo é o estado do Paraná, na região Sul, que alcança praticamente 500 ocorrências do termo paisagem. No sul, os estados não apresentaram diferenças tão extremas no uso do termo, pois Santa Catarina alcança 300 ocorrências enquanto o Rio Grande do Sul chega perto dos 400 (Gráfico 3).

Gráfico 3 - Número de ocorrências do termo paisagem na jurisprudência dos Tribunais de Justiça dos estados da região Sul

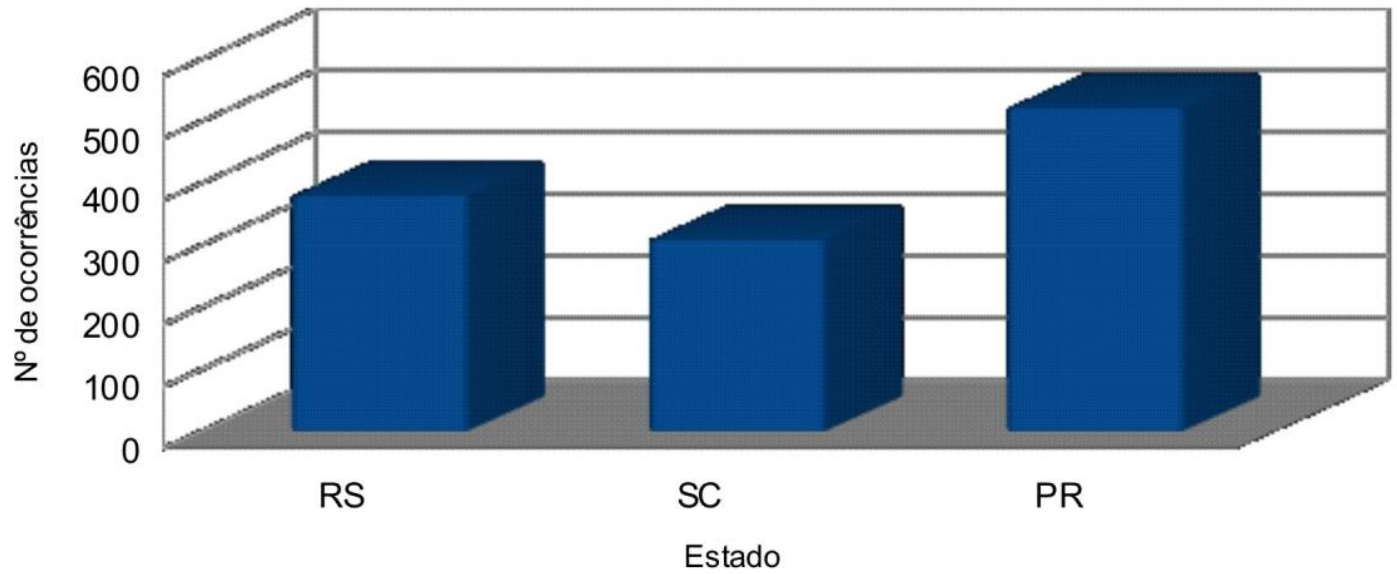

Fonte: Elaborado pelo autor com base nos dados da pesquisa. 
Nos estados do Maranhão, Piauí, Amazonas, Roraima, Tocantins, Amapá e Rondônia, a palavra paisagem não aparece nenhuma vez na jurisprudência dos Tribunais de Justiça respectivos (Gráficos 4 e 5). E mesmo nos outros estados, a quantidade de vezes que paisagem aparece na jurisprudência é mínima: o Acre e o Pará tiveram apenas 1 processo cada onde aparece citada a palavra paisagem.

Gráfico 4 - Número de ocorrências do termo paisagem na jurisprudência dos Tribunais de Justiça dos estados da região Norte

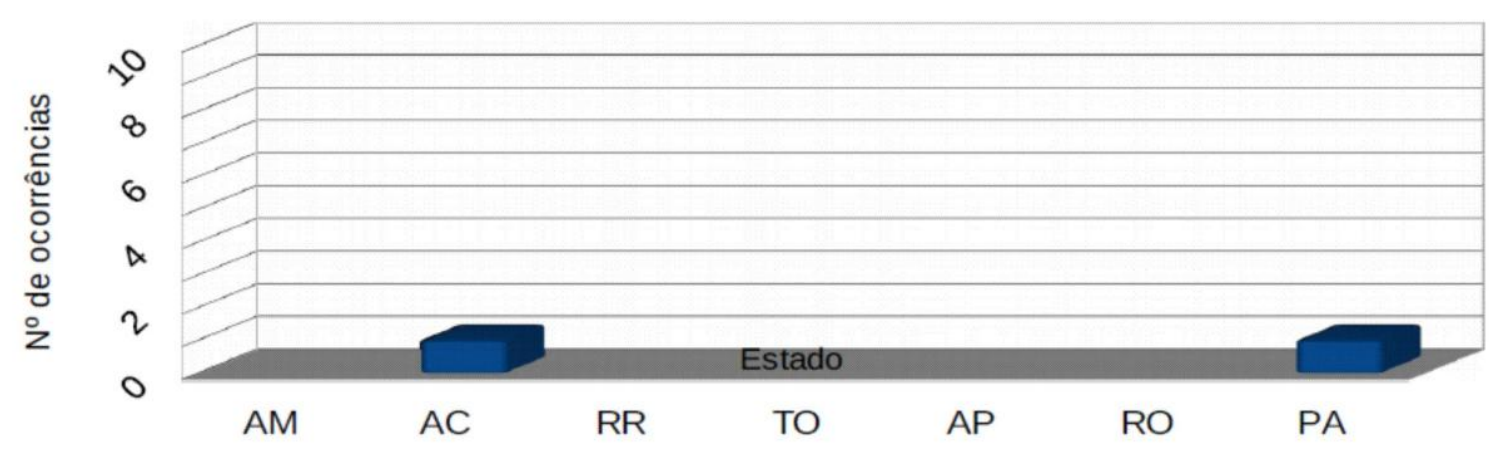

Fonte: Elaborado pelo autor com base nos dados da pesquisa.

Gráfico 5 - Número de ocorrências do termo paisagem na jurisprudência dos Tribunais de Justiça dos estados da região Nordeste

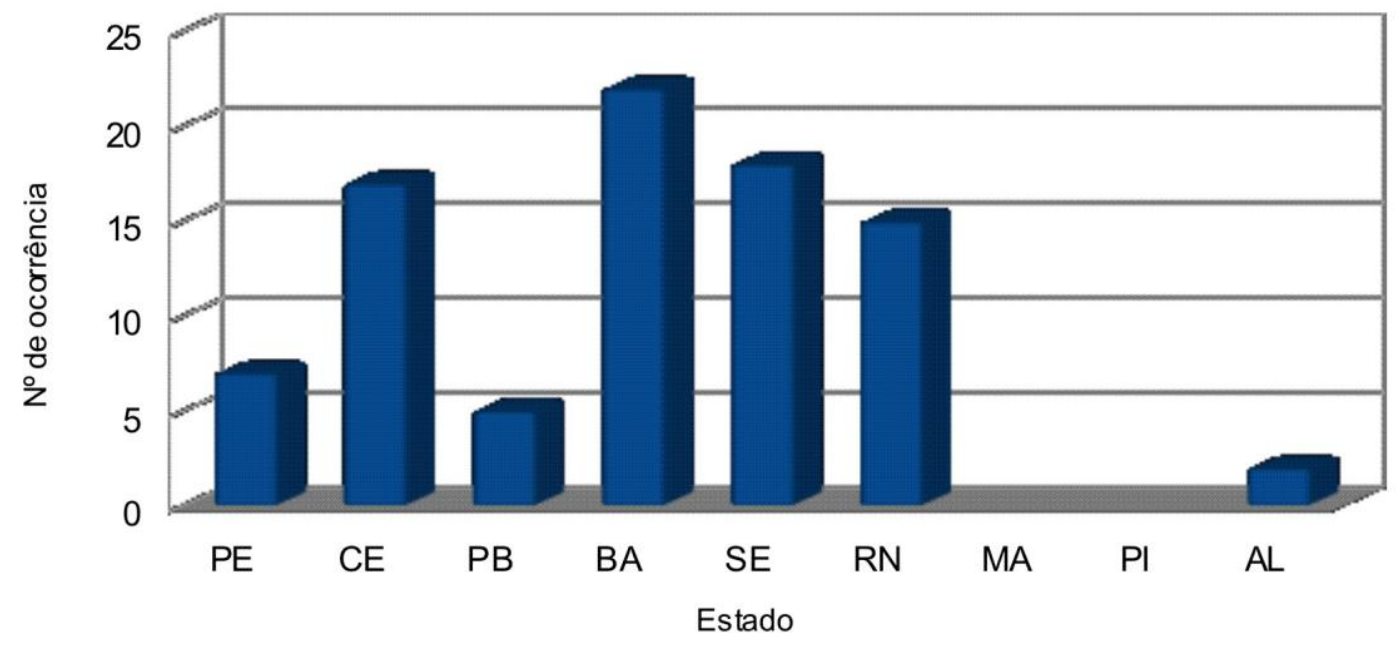

Fonte: Elaborado pelo autor com base nos dados da pesquisa.

Os estados do Centro-Oeste e o Distrito Federal são bem contrastantes também: enquanto o Distrito Federal chega a quase 140 ocorrências, o estado de Goiás não alcança 20 (Gráfico 6). 
Gráfico 6 - Número de ocorrência do termo paisagem na jurisprudência dos Tribunais de Justiça dos estados da região Centro-Oeste

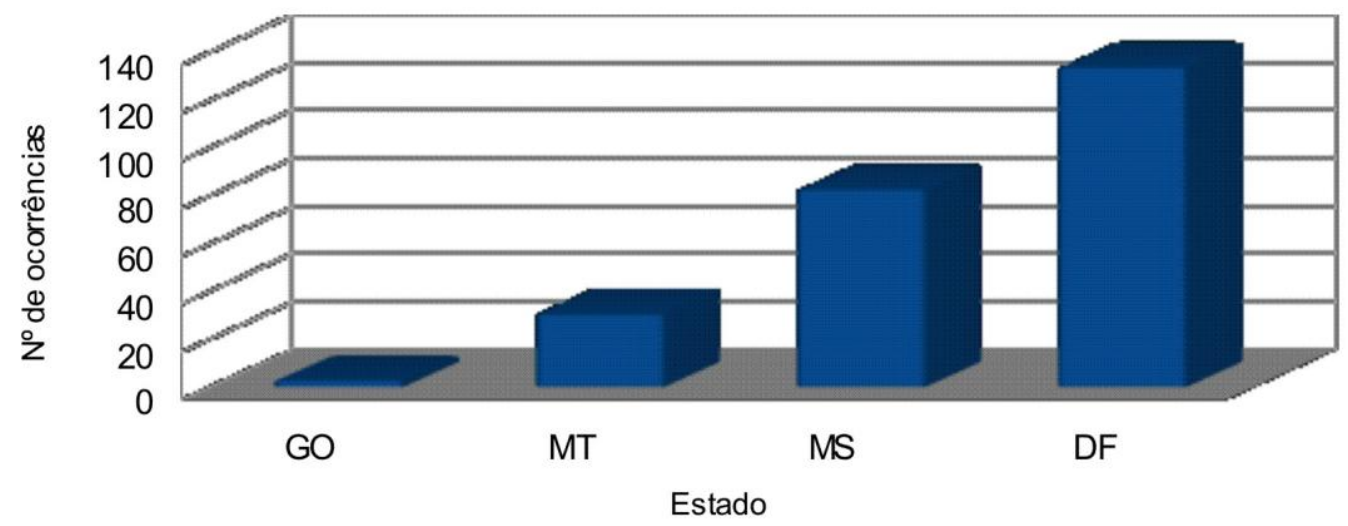

Fonte: Elaborado pelo autor com base nos dados da pesquisa.

Podemos observar, com a ajuda dos gráficos, que a distribuição no uso do termo paisagem pelos Tribunais de Justiça estaduais varia consideravelmente, apesar de ser necessário ressaltar a requerida análise estatística mencionada. Em algumas regiões, o uso do termo paisagem é significativamente maior que em outras e, mesmo em uma mesma região, alguns estados destacam-se em relação aos outros. Tal situação enseja questionamentos geográficos importantes, tais como a distribuição e efetivação dos "direitos de paisagem". A concentração das ocorrências nas regiões Sul e Sudeste pode revelar uma percepção e uma apropriação jurídica diferenciada da ideia de paisagem, em contraste com o pouco uso representado pelas regiões Norte, Nordeste e Centro-Oeste.

Os diferentes graus de desenvolvimento econômico e institucional entre as regiões, a densidade da urbanização e os melhores índices sociais na área de educação e cultura nas regiões Sul e Sudeste são hipóteses que podem contribuir na explicação desta desigual distribuição geográfica encontrada. Com efeito, estruturas e órgãos públicos mais bem aparelhados, bem como organizações da sociedade civil de defesa da paisagem podem estar relacionados à maior demanda judicial para salvaguarda das paisagens. Ademais, pode ocorrer um maior ativismo na educação paisagística promovido pelo poder público, universidades ou associações civis, sensibilizando a sociedade em torno da questão.

Não obstante as questões geográficas e hipóteses que podem ser levantadas, das quais não temos elementos para uma análise aprofundada, o uso do termo 
paisagem será analisado segundo o sentido que adquire nos processos judiciais do Tribunal de Justiça de Minas Gerais.

\subsection{SIGNIFICADO DA PAISAGEM NO TRIBUNAL DE JUSTIÇA DE MINAS GERAIS}

Para sabermos como o termo paisagem é interpretado nos processos, começamos a pesquisa pelo Tribunal de Justiça de Minas Gerais: pesquisamos a jurisprudência disponível no site oficial do Tribunal de Justiça do Estado entre os meses de dezembro de 2014 e janeiro de 2015. A pesquisa foi feita selecionando o inteiro teor dos processos, acórdãos e a partir da palavra-chave de entrada "paisagem".

Obtivemos 924 processos como resultado. Optando por uma análise qualitativa, realizamos uma leitura sumária de todos os processos e, na medida em que o uso do termo apresentava características semelhantes, selecionamos aqueles cujo mérito se mostrou mais representativo do conjunto e mais significativo para os objetivos almejados.

Apreende-se da leitura dos processos, de início, a existência de um direito à paisagem. Na verdade, a própria inscrição do termo nos textos legais já coloca a paisagem como direito, mas os processos nos trazem mais próximos do conteúdo de sua aplicação judicial.

A paisagem como direito aparece, por exemplo, quando da controvérsia a respeito da construção de uma concha acústica na Praça Monsenhor Pedro Cintra, no município de Borda da Mata. Para o município "não restou comprovado que a paisagem central da cidade iria ser desfigurada" e que "a concha acústica iria compor o conjunto arquitetônico e paisagístico do Município" (MINAS GERAIS, Apelação Civil/Reex Necessário no 1.0083.12.001095-0/001, 2013a, p. 3). Porém, na decisão do mérito da questão, firmou-se entendimento que a construção, "além de não se tratar de uma simples obra de embelezamento, trará alterações no conjunto arquitetônico e paisagístico da cidade" (MINAS GERAIS, Apelação Civil/Reex Necessário no 1.0083.12.001095-0/001, 2013a, p. 6). Visando à proteção ao "monumento paisagístico da cidade", declarou-se então a nulidade do contrato para execução das obras na praça municipal.

Outro interessante caso em que se garantiu o direito à paisagem ocorreu no município de Mariana e referia-se à venda de lotes, cujo principal atrativo era a 
"paisagem enriquecida pela lagoa". Afirma o juiz que "se as vendas dos lotes foram realizadas e firmadas na confiança de ter seu imóvel à margem ou com vista para a lagoa (...) [o loteador] não pode modificar ou permitir que modifiquem substancialmente àquela paisagem" (MINAS GERAIS, Agravo de Instrumento no 1.0400.05.018073-8/001, 2006a, p.3). Assim, manteve-se a decisão anterior que obrigava o empreendedor a reconstituir a lagoa outrora esvaziada pela destruição de uma barragem.

A paisagem também aparece como direito quando sua modificação enseja danos morais ambientais. Por exemplo: a retirada de cascalho por uma construtora para asfaltamento de rodovia havia ocasionado, segundo vistoria da secretaria do meio ambiente, alteração do relevo e da paisagem. Tal fato deu azo para que os proprietários do imóvel atingidos pelas alterações na paisagem ajuizassem ação pleiteando direito a danos morais (não aceito pelo juiz, contudo, pois o direito havia prescrito) (MINAS GERAIS, Apelação Civil no 1.0086.11.001987-3/001, 2013b).

Nestas sentenças, as figuras de proteção a monumento paisagístico, de visão da paisagem ou da proteção contra alterações danosas evocam certo direito à paisagem; em nenhum momento, entretanto, neste e noutros processos, fala-se expressamente de direito à paisagem, nem se elabora uma teoria do que seria este direito.

Além da paisagem como Direito, cabe sublinhar os sentidos no uso do termo pelo Tribunal de Justiça mineiro.

No conjunto dos processos analisados predomina o aspecto material, estético e visual no uso do vocábulo, seja a paisagem adjetivada como urbana ou natural. Em outras palavras, são os danos estéticos negativos ou os impactos visuais na forma material da paisagem urbana e natural que se tenta cessar ou evitar.

No município de Belo Horizonte, a instalação de estações de rádio base por empresa de telecomunicações foi objeto de ação porque, dentre outras razões, as antenas "podem modificar intensamente a paisagem urbana". Procurava-se evitar que "os tipos de equipamentos a serem instalados não causassem impactos visuais às características daqueles bens [tombados] nem à paisagem" (MINAS GERAIS, Agravo de Instrumento no 1.0024.13.129727-7/001, 2013c, p.4). Na decisão de mérito, aduz o juiz que os engenhos humanos "podem modificar sobremaneira a paisagem urbana, causando impactos diversos, inclusive visuais negativos", afetando a qualidade de vida das populações (MINAS GERAIS, Agravo de 
Instrumento $\mathrm{n}^{0}$ 1.0024.13.129727-7/001, 2013c, p. 14). Nesta direção, o juiz cita como argumento de autoridade a doutrina de Édis Milaré, para o qual a paisagem também se equaciona em torno da harmonia estética urbana, sendo a poluição visual o principal elemento negativo que afeta a paisagem urbana (MINAS GERAIS, Agravo de Instrumento oㅜ 1.0024.13.129727-7/001, 2013c, p. 15-16).

É também num processo envolvendo o município de Belo Horizonte que se vê a relação da paisagem urbana com a estética da cidade: "De presumir-se a efetividade da fiscalização exercida pelos agentes da municipalidade de Belo Horizonte no controle da exploração e utilização da publicidade na paisagem urbana, com vistas a evitar prejuízos à estética da cidade e à segurança dos munícipes" (MINAS GERAIS, Apelação Civil no 1.0024.05.685939-0/001, 2007a, p.4).

No mesmo sentido, para evitar a "completa descaracterização da paisagem natural" da Serra dos Cristais, no município de Diamantina, julgou-se procedente o indeferimento de alvará de construção localizada ao pé da Serra uma vez que a construção reduziria a visibilidade do bem tombado (a Serra dos Cristais), causando "impacto muito grande na paisagem da Serra, descaracterizando aquela paisagem preservada" (MINAS GERAIS, Mandado de Segurança ํㅜ 1.0216.06.040037-3/001, 2007b, p. 6).

Por último, um processo no Município de Mariana: certa construção de escola em área de preservação arqueológica (Sítio do Gogô) foi questionada face aos danos causados "à paisagem cultural na qual estão inseridas as ruínas" e "embora não exista reconhecimento formal de toda sua extensão, tais obras contribuem para descaracterizar a topografia e o aspecto visual natural da área" (MINAS GERAIS, Agravo de Instrumento no 1.0400.07.027129-3/001 2008a, p. 3).

É, em suma, a paisagem material na sua qualidade visual, fisionômica e estética que marca o seu uso na jurisprudência do Tribunal de Justiça de Minas Gerais e que, por outro lado, encaminha o direito à paisagem a sua dimensão estética e visual.

Outra característica importante a ressaltar - e que os processos anteriormente citados já antecipam - diz respeito ao caráter natural ou urbano da paisagem. Isto é, há um entendimento tácito de que o visual da paisagem configurase pelo conjunto dos elementos naturais ou construídos; no primeiro caso, a paisagem confunde-se com a natureza e, no segundo, com as formas urbanas. 
A propósito da paisagem como natural, percebe-se nos processos a repetição dos artigos das leis que tratam das áreas de preservação permanente e, de fato, é frequente a reprodução dos textos das leis federais $n^{0} 12.651 / 2012$ e no 4.771/1965 e da lei estadual $\mathrm{n}$ ํ114.309/2002.

No município de Poços de Caldas, por exemplo, constatou-se dano à floresta "que tem como função a preservação permanente de recursos hídricos, da paisagem da estabilidade geológica, da biodiversidade (...)" (MINAS GERAIS, Apelação Criminal no 1.0518.06.105934-2/001, 2011a, p. 2). Noutro julgamento, no município de Lima Duarte, a supressão da vegetação de topo de morro está associada à "preservação da paisagem, dos recursos hídricos, da biodiversidade (...)" (MINAS GERAIS, Apelação Criminal no 1.0386.07.007037-3/001, 2014b, p. 7). Nestes processos, importa destacar a colocação da paisagem dentro de uma controvérsia sobre o meio ambiente natural, o que leva à compreensão da paisagem também como natural.

O mesmo se diga quanto à paisagem urbana, a qual é constantemente conjugada com as leis municipais de tombamento ou de preservação da paisagem urbana propriamente dita.

\subsection{DANO MORAL AMBIENTAL: USO NO TRIBUNAL DE JUSTIÇA DE MINAS GERAIS}

Para sabermos como o dano ambiental (patrimonial e extrapatrimonial) é usado nos processos e, via de consequência, qual o significado do meio ambiente, foi realizado, em julho de 2016, o mesmo procedimento empregado na pesquisa do termo paisagem.

Restringimos a busca ao Tribunal de Justiça do Estado de Minas Gerais, porém, devido aos vícios que a pesquisa por Estado da federação e o Distrito Federal apresentam. Isso porque, assim como a pesquisa sobre a ocorrência do termo paisagem, também neste caso os resultados obtidos por Estado mereceriam um tratamento estatístico apropriado que desse a porcentagem de ocorrência em relação ao número total de processos existentes em cada Tribunal.

Outro vício dos resultados por federação reside no fato de que nem sempre é possível garantir a busca em função de todas as condicionantes mencionadas já que 
a ferramenta de busca de alguns sites não permite tal seleção. Então, por exemplo, no Tribunal de Justiça do Estado do Rio Grande do Norte, mesmo utilizando ferramentas para restringir a pesquisa à exata expressão, a busca pelo termo "dano moral ambiental" acusa processos que no seu inteiro teor citam apenas "dano moral" e não somente "dano moral ambiental".

Aumenta a dificuldade da pesquisa o uso de "dano moral" no lugar de "dano moral ambiental" nas discussões de mérito dos processos, ou seja, embora haja dano ambiental, a repercussão na esfera íntima da pessoa ou comunidade é categorizada como "dano moral" apenas e não como "dano moral ambiental".

llustra o dito os repetidos processos que cuidam do rompimento de uma barragem de lavras de bauxita, em 2007, localizada em Miraí - MG. O rompimento da barragem provocou a inundação, pela lama de rejeitos da mineração, de bairros e casas da cidade de Muriaé - MG, dando causa a inúmeros processos. Neles, o mérito da questão residia na constatação ou não de nexo de causalidade entre o dano sofrido pelas vítimas e o rompimento da barragem sob responsabilidade da mineradora encarregada da lavra (esta alegou-se em contraditório que a inundação havia sido causada pelas fortes chuvas na região). Reconhecem os juízes o dano ambiental causado e o sofrimento ocasionado às pessoas, mas este é dito "dano moral" e não "dano moral ambiental".

De fato, assevera um primeiro desembargador que as inundações do rio Muriaé, consequência ou não do rompimento da barragem,

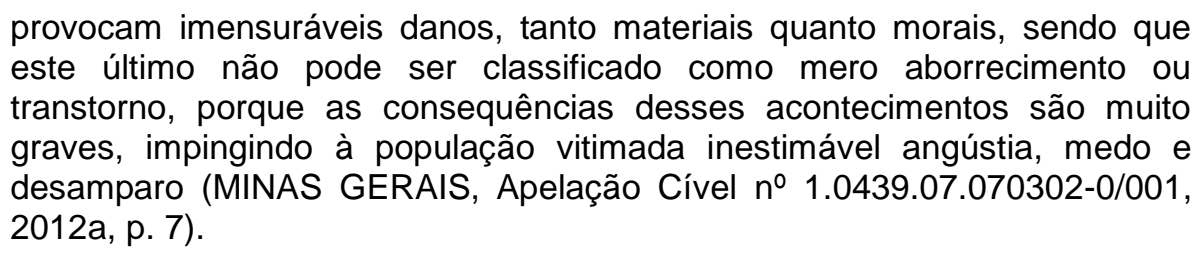

Porém, tais danos não são classificados como "danos morais ambientais" por estarem vinculados a um dano ambiental. Fala-se apenas em "danos morais", como mostra o voto de um segundo juiz do mesmo caso:

No caso, o dano moral restou caracterizado em razão da inequívoca ofensa à dignidade humana da autora, a qual, reprisa-se, em razão do dano ambiental provocado pelo rompimento da barragem, teve sua casa invadida por lama, o que gerou um verdadeiro caos, com consequências diversas, notadamente o comprometimento do uso regular do imóvel (MINAS GERAIS, Apelação Cível no 1.0439.07.070302-0/001, 2012a, p. 10) (Grifos nossos). 
Igualmente exemplificativo do emprego de "dano moral" à "dano moral ambiental" são os processos que tratam do aprisionamento de pássaros silvestres. Em Belo Horizonte, em 2008, a manutenção de pássaros em cativeiro (1 papagaio verdadeiro e 2 canários chapinha) foi tido como dano ambiental com efeitos morais por constituir ofensa ao direito difuso ao meio ambiente (MINAS GERAIS, Ação Cível Pública no 1.0024.03.115978-3/001, 2008b).

\footnotetext{
A apreensão, pela polícia ambiental, de pássaros mantidos em cativeiro, para serem reintegrados ao meio ambiente, caracteriza ofensa que extrapola o terreno dos danos meramente patrimoniais, constituindo, em verdade, danos com efeitos morais ou simplesmente danos extrapatrimoniais, com ofensa ao direito difuso ao meio ambiente (MINAS GERAIS, 2008b, Ação Cível Pública no 1.0024.03.115978-3/001, p. 1).
}

Um caso semelhante já havia sido julgado, em 2005, pelo Tribunal de Justiça de Minas Gerais no mesmo sentido, quer dizer, a manutenção da fauna silvestre em cativeiro (3 sabiás, 2 assanhaços, 1 cardeal, 2 tico-tico comuns, 1 patativa, 3 bicos de veludo, 1 bico de pimenta, 1 tico-tico-rei e 1 estrelinha) caracteriza dano ambiental os quais, "extrapolam o terreno dos danos patrimoniais, constituindo, em verdade, danos com efeitos morais ou simplesmente danos extrapatrimoniais" (MINAS GERAIS, Apelação Cível n 1.0024.03.131618-5/001, 2006b, p. 4).

Em ambos os casos, há de observar-se que o dano moral reconhecido vincula-se antes ao direito difuso ao meio ambiente do que à repercussão negativa sobre a esfera íntima da pessoa, com dor, sofrimento e angústia. Defende-se o interesse da coletividade na preservação do meio ambiente ecologicamente equilibrado.

Também demandou pedido por danos morais coletivos a contaminação do solo e água subterrânea em certo posto de gasolina por vazamento em Belo Horizonte. Os danos ambientais reconhecidos (a contaminação do solo e da água subterrânea é tipificada como dano ambiental) deu azo para o pleito de danos morais (MINAS GERAIS, Recurso em sentido estrito ํo 1.0702.09.598762-5/001, 2011b).

Quando o excesso de ruído proveniente de um shopping provocou poluição sonora, os vizinhos do estabelecimento pleitearam danos morais pelo incômodo e doenças que tiveram. Perdendo em primeira instância, o Tribunal de Justiça mineiro reformou a sentença no sentido de reconhecer os danos morais gerados pelo barulho: 
A sentença vergastada [sentença da primeira instância] julgou improcedente o pleito de indenização a título de danos morais, sob os fundamentos de que a prática de atividade poluidora, por si só, não configura dor, sofrimento, angústia ou aflição, passíveis de indenização e de que não há, nos autos, documentos que comprovem o nexo de causalidade entre as doenças relatadas e os atos ilícitos praticados pelos réus.

(...) o desconforto de encontrar-se exposto a ruído excessivo, a meu ver, ultrapassa a barreira dos meros aborrecimentos, daquele dissabor que 0 cidadão deve absorver como realidade da vida em sociedade e decorrente de suas relações. A conduta dos requeridos causou uma sucessão de incômodos aos autores, sendo inegável que a perturbação do seu sossego, no período noturno, caracteriza ofensa ao Direito de personalidade (MINAS GERAIS, Apelação Cível oㅜ1.0024.06.069158-1/001, 2015a, p. 5).

Feitas as ressalvas acima, no segundo semestre de 2016 analisamos o uso do termo "dano moral ambiental" e "dano ambiental extrapatrimonial" no Tribunal de Justiça do Estado de Minas Gerais. A pesquisa foi feita nos acórdãos, inteiro teor dos processos, no período de 1988 a 2015. Foram localizados 97 processos (96 para "dano moral ambiental" e 1 para "dano ambiental extrapatrimonial").

Para saber quais os tipos de danos ambientais geraram como consequência danos morais ambientais ou danos ambientais extrapatrimoniais, os processos foram analisados e os fatos que ocasionaram a lide foram classificados conforme apresentado no quadro 6.

\section{Quadro 6 - Eventos geradores de dano moral ambiental}

TERMO

EVENTOS TIPIFICADOS COMO DANO AMBIENTAL

- Poluição sonora

Dano moral

Dano ambiental extrapatrimonial

Dano moral ambiental
- Inundação de rio por lama de barragem

- Aprisionamento de pássaros da fauna silvestres

- Aprisionamento de pássaros da fauna silvestre

- Poluição sonora

- Contaminação de recursos hídricos

- Loteamento irregular (degradação dos recursos hídricos; prejuízos ao solo, a fauna e flora)

- Intervenção em área de preservação permanente (Desmatamento, plantio de cana, edificações, modificações na paisagem, morte de animais silvestres)

- Morte de animais em zoológico

- Desvio, drenagem e aterro de curso d'água

- Desmatamentos

Total de acórdãos: 355

Fonte: Elaborado pelo autor com base nos dados da pesquisa. 
A primeira observação da tabela mostra que predomina como fato gerador de dano ambiental as lesões aos elementos naturais no meio, como a matança ou aprisionamento da fauna silvestre, a poluição sonora e atmosférica, desmatamentos, degradação dos recursos hídricos, erosão do solo, etc.

No primeiro caso analisado, aquele que diz "dano ambiental extrapatrimonial", o magistrado discute a indenização por haver, novamente, a manutenção em cativeiro de pássaros da fauna silvestre. $O$ mérito do processo cuida da indenização por danos ambientais, não alcançando, contudo, discussão sobre o dano moral extrapatrimonial, embora a expressão seja usada no texto. De qualquer forma, manter em cativeiro pássaros da fauna silvestre, o que impossibilitou "os pássaros de cumprirem a sua função ecológica e contribuiu para o desequilíbrio do meio ambiente", foi caracterizado como dano ambiental (MINAS GERAIS, Apelação Cível no 1.0024.05.700750-2/001, 2008c).

Poluição sonora é outro fato gerador de dano moral ambiental. Em um dos casos, uma casa de shows que organizava bailes funk em Belo Horizonte causou "degradação ao meio ambiente, desconforto, irritabilidade, e perturbação da paz social, em razão da poluição sonora provocada", sendo cabível o dano moral ambiental coletivo (MINAS GERAIS, Ação Civil Pública no 1.0024.13.377739-1/001, 2015b, p. 4).

Dano ambiental também ocorre em loteamentos irregulares onde falta infraestrutura básica, especialmente, drenagem de águas pluviais, "fazendo o uso de cisternas e lançamentos de esgotos domésticos em fossas, ocasionando degradação do lençol freático, gerando danos ao meio ambiente e urbanísticos" (MINAS GERAIS, Apelação Cível no 1.0625.11.003277-2/002, 2014c, p. 23). Os danos ambientais provocados pelo loteamento podem ser lidos num excerto do laudo técnico que vistoriou a área:

O laudo técnico de fls. 67/78 demonstra claramente os danos ambientais, ressaltando que "as águas pluviais escoam livremente sobre o leito das ruas 07, 08, 09 e 10, o que gera assoreamento da APP e curso d'água a jusante". Ressalta ainda que com a intervenção do campo de futebol houve rebaixamento do lençol freático e provável deslocamento da nascente, impedindo a regeneração florestal da mata ciliar, bem como loteamento em área de APP na quadra "V", com prejuízo ao solo, à flora e à fauna, além de lançamento de esgoto clandestino sobre o curso d'água, com prejuízo à qualidade de água e à saúde da população, bem como os demais danos ambientais descritos à f. 72 .

E ainda à f. 75:

O lançamento de efluentes domésticos sem tratamento inviabiliza diversos usos humanos dos ecossistemas aquáticos (...) Os danos ambientais decorrentes do lançamento in natura de esgotos em corpos hídricos 
também são enormes (...) (MINAS GERAIS, Apelação Cível $n^{\circ}$ 1.0625.11.003277-2/002, 2014c, p. 28).

Intervenções em área de preservação permanente são constantemente tidas como de dano ambiental, mas este não necessariamente gera dano moral ambiental, porquanto ou o dano é pequeno, ou não causa impacto na comunidade, ou é incabível em caso de sujeitos indeterminados.

Um embargo de declaração oposto pelo Ministério Público mineiro pedia que fosse reconhecida a ocorrência de dano moral ambiental em face de lesão sofrida pelo meio ambiente, qual seja o desmatamento empreendido em área de preservação permanente. Atendendo ao pedido do Ministério Público, isto é, reconhecido o dano moral ambiental, o magistrado porém, julgou improcedente o pedido de indenização dada a "reduzida área desmatada e a precária situação econômica dos demandados" (MINAS GERAIS, Embargo de Declaração $n^{\circ}$ 1.0132.06.003144-1/002, 2014d, p. 3).

Em Uberaba, a Polícia Militar Ambiental apurou intervenção em área de preservação permanente para o plantio de açúcar, levando o Ministério Público a interpor ação por, dentre outros, danos morais ambientais. O juiz, entretanto, considerou que "o dano moral ambiental 'in casu' foi somente potencial, não lesou pessoas determinadas e nem causou impacto direto na comunidade local. Logo, a indenização por dano moral ambiental é mesmo incompatível com a noção de transindividualidade" (MINAS GERAIS, Apelação Cível no 1.0701.09.260144-5/001, 2014e, p. 14).

A supressão da vegetação e degradação de área de preservação permanente advinda da exploração de jazida de sienito no maciço da Serra de Pedra Branca, localizada no município de Caldas-MG causou danos comprovados ao meio ambiente.

A extração do mineral em área não devidamente licenciada "causou prejuízo ao meio ambiente, conforme as perícias e vistorias supramencionadas", afirma o juiz na decisão de mérito. Para o magistrado, ainda, a atividade mineradora "alteraram o estado natural da Serra da Pedra Branca" (MINAS GERAIS, Apelação Cível no 1.0103.06.000376-3/001, 2012b, p. 11-12).

O primeiro laudo citado no processo elenca os seguintes danos ambientais: 
movimentação de máquinas e equipamentos para o corte e retirada dos blocos e devido ainda a deficiência e ineficiência dos sistemas de condução, drenagem e retenção dos sedimentos (bacias de decantação), constatamos vários locais degradados devido a erosão e constatamos também que as águas das chuvas estão carreando sedimentos em direção aos cursos d'água, estradas, etc. (...).

Outro grande impacto causado pela mineradora é o visual, gerado principalmente, pelos enormes depósitos de rejeitos localizados na parte frontal da área. Estando a mineradora localizada logo abaixo da Pedra Branca (um dos mais belos cartões-postais do município) este impacto tem contribuído para a formação de uma imagem negativa desse atrativo turístico. Não existe na área cortina vegetacional procurando minimizar este impacto (MINAS GERAIS, Apelação Cível no 1.0103.06.000376-3/001, 2012b, p. 8).

O segundo laudo técnico lista:

Os impactos ambientais observados em campo, provocados pela extração intensificada de sienito na região vistoriada, basicamente referem-se a:

A) Poluição visual das frentes de lavra, principalmente nas frentes abandonadas (devido a problemas com a textura ou estrutura da rocha, ocasionando um material fora dos padrões comerciais), que são descartadas sem preocupação com sua recuperação morfológica e topográfica (modificações na paisagem). A operação de equipamentos provoca, ainda, modificações de relevo nos locais de extração e vias por onde são transportados o material.

B) $(\ldots)$

C) Deposição inadequada de material lavrado (blocos), próximos às frentes de lavra, gerando a formação de várias aglomerações irregulares;

D) Alteração na drenagem das águas superficiais (...);

E) Geração de poeira (poluição atmosférica), nas frentes de extração (material desagregado);

F) Alteração nas calhas dos cursos d'água. Também verifica-se que a extração efetuada a montante das margens dos cursos d'água locais e a declividade do terreno, associado ao tipo de solo que compõe os taludes das margens, podem ocasionar a sua instabilidade.

Podem ser citados, ainda, a poluição sonora causada pela denotação de explosivos, pelos motores isolados e equipamentos de extração, carregamento e transporte, a interferência direta sobre a fauna provocando evasão ou alterações nos hábitos dos animais da região, a compactação do solo que contribui para 0 arraste de sedimentos para os corpos d'água" (MINAS GERAIS, Apelação Cível no 1.0103.06.000376-3/001, 2012b, p. 8).

A exploração de cascalho em área de preservação permanente deu azo para uma ação civil pública que pedia a condenação pelos danos ambientais causados e indenização por danos morais ambientais. O juiz relator acolheu a perícia técnica realizada na área em questão, constatando o dano ambiental em área de preservação permanente:

Com efeito, a área de preservação permanente serviu aos interesses econômicos da empresa exploradora de recurso mineral em área interditada para tanto. Ademais, não há dúvida que a exploração de recurso mineral trouxe danos ao meio ambiente, muitos deles irreversíveis. Neste aspecto, a irresignação é mesmo inacolhível (MINAS GERAIS, Apelação Cível no 1.0702.96.002497-5/002, 2004, p. 7). 
Sobre os danos causados, é possível ler no trecho citado da perícia:

O perito do juízo, após exaustiva análise, concluiu que a área objeto da demanda contém solos hidromórficos, com várias nascentes e cabeceiras de curso de água, constituindo local de interesse comum e preservação permanente. Acrescentou ter encontrado vestígios de exploração recente em cava como decorrência de existir equipamentos, vasilhames contendo combustível e óleo lubrificante e marcas de pneumáticos. Afirmou que a exploração mencionada removeu substancial quantidade de solos hidromórficos, tendo como resultado a interferência do armazenamento e dinâmica hídrica do local. Afirmou, ainda, haver na área cavas antigas em regeneração e fase de reequilíbrio. Acrescentou que a recomposição somente pode ser parcial (MINAS GERAIS, Apelação Cível $\mathrm{n}^{\text {}}$ 1.0702.96.002497-5/002, 2004, p. 5).

Figura entre os danos ambientais as lesões ao meio ambiente causadas pelas atividades de empresa de transporte na cidade de Uberlândia: o uso de posto no abastecimento de combustível e a lavagem de veículos causou degradação ao meio ambiente com a contaminação de recursos hídricos. Contudo, o dano moral ambiental é negado pela impossibilidade de indicar os sujeitos afetados.

No entanto, a possibilidade de reconhecimento do "dano extrapatrimonial ambiental" exige uma apreciação minuciosa da situação fática, com interpretação que invariavelmente leva à alteração do próprio conceito de dano moral, notadamente a sua vinculação aos direitos da personalidade e ao significado de "dor", com o fito de abranger sua incidência à coletividade. A conexão do Direito Ambiental ao Direito de personalidade para fins de reparação por dano extrapatrimonial coletivo encontra obstáculos na impossibilidade de se determinar o sujeito passivo do dano, bem como na indivisibilidade da ofensa e da reparação (..) (MINAS GERAIS, Apelação Cível no 1.0702.09.604039-0/001.2012c, p. 13).

A morte de animais silvestres decorrentes de desmate em área de preservação permanente é igualmente caracterizada como dano ambiental. No município de Caranaíba, 4,5 hectares de floresta estacional semidecidual foram desmatados para a produção de carvão vegetal, porém, além do ato ilegal de desmate em APP, espécies da fauna silvestre também foram atingidas (MINAS GERAIS, Apelação Cível no 1.0132.05.001724-4/001, 2013d).

Outro caso de dano ambiental gerado pela morte de animais ocorreu em Uberlândia-MG, no Zoológico Parque do Sabiá. Assim se manifestou o juiz: "deve-se reconhecer a responsabilidade do ente público pela falha na segurança de zoológico municipal, sabidamente precária, e que teve por consequência a morte e subtração de animais do local, gerando evidente dano ambiental" (MINAS GERAIS, Apelação Cível no 1.0702.10.005258-9/003, 2013e, p. 2). 
O desvio, drenagem e aterro de afluente do rio São Francisco ensejou condenação por danos ambientais de empresa agrícola localizada na cidade de Luz - MG. Não foi provado, contudo, o vínculo entre o dano ambiental e ofensa à coletividade, motivo pelo qual o juiz indeferiu o pedido do Ministério Público por danos morais ambientais (MINAS GERAIS, Apelação Cível nำ 1.0388.03.0040157/001, 2012d).

A ocorrência de dano ambiental, por vezes, depende fundamentalmente de perícias e vistorias, feitas por autoridades públicas ou técnicos particulares, para formar a convicção dos juízes sobre a situação de fato. Em Belo Horizonte, no primeiro semestre de 2000, um acidente ferroviário com o descarrilamento de 11 vagões carregados de óleo diesel e gasolina gerou diferentes interpretações sobre a ocorrência ou não de danos ao meio ambiente segundo variavam os resultados dos laudos técnicos.

O laudo de vistoria expedido pelo IBAMA realizado um dia após o acidente elencou uma extensa lista de danos provocados:

O laudo de vistoria expedido pelo Instituto Brasileiro do Meio Ambiente e
dos Recursos Naturais Renováveis (IBAMA), realizado um dia após o
acidente, afirma que com o acidente, em relação à vegetação, foram
afetadas duas áreas; uma, com cerca de $1.400 \mathrm{~m} 2$ pela queima de
vegetação rasteira e árvores de médio e grande porte e a outra, numa
superfície total de aproximadamente $600 \mathrm{~m} 2$, foi afetada em razão do
escoamento do óleo; quanto ao solo, sua carbonização e infiltração em
razão do derramamento; no ar, constatou-se poluição atmosférica,
proveniente da queima dos produtos atingidos, com emissão de gases,
material particulado, além de aumento de temperatura; quanto aos recursos
hídricos, anotou-se que todo o material não queimado foi carreado para o
curso d'água denominado "córrego do cachorro Magro", tributário do
"Ribeirão Arrudas" que por sua vez é afluente do "Rio das Velhas"; que a
empresa tomou medidas de contenção para a retenção do óleo e, por fim,
quanto à fauna, afirmou que toda a forma de vida que porventura se
encontrava na área atingida foi incinerada, sem possibilidade de vestígios,
ficando prejudicada a avaliação dos danos (MINAS GERAIS, Apelação Cível
no $1.0024 .03 .971351-6 / 001,2008 d$, p. 6-7).

Um segundo laudo produzido "vários anos da ocorrência do acidente", elaborado por biólogo a pedido do Ministério Público, concluiu que "atualmente não existem danos ambientais que mereçam atenção e recuperação" (MINAS GERAIS, Apelação Cível no 1.0024.03.971351-6/001, 2008d, p. 9). Sobre a fauna e a flora diz:

entre a data do sinistro com o comboio e a execução deste estudo, decorreu um tempo significativo, o que propiciou a regeneração herbácea (capins, citados no inventário florístico) e arbustiva. Quanto à vegetação arbórea, ao que tudo indica e, pelas oitivas e entrevistas no local, esta não sofreu danos, pois não foi atingida pelo acidente. 
(...) tanto a flora quanto a fauna são pobres em diversidade biológica no local. Todos que aí ocorreram são constantes e ubíquos dos domínios do cerrado, além daquelas pioneiras, invasora e ruderais da flora exótica (MINAS GERAIS, Apelação Cível no 1.0024.03.971351-6/001, 2008d, p. 9$10)$.

Conclui o biólogo mais a frente:

atualmente não existem danos ambientais que mereçam atenção e recuperação. O local no qual foi observado um residual de óleo consistente em uma pequena área cuja contaminação, além de ser superficial, a 1,5 m de profundidade, é de baixa concentração, cerca de 40 ppm de VOC (concentração de orgânicos voláteis). O que confirma também tal afirmação é que o furo de sondagem de $12 \mathrm{~m}$ de profundidade realizado no mesmo ponto com o objetivo de colher amostras, não conseguiu alcançar o lençol subterrâneo, isto é, o risco desta pequena contaminação atingir o lençol freático é praticamente nulo (MINAS GERAIS, Apelação Cível $\mathrm{n}^{\circ}$ 1.0024.03.971351-6/001, 2008d, p. 11).

Interessante anotar que no segundo laudo técnico, o biólogo não defende a proteção da vegetação remanescente na área do acidente para fins de regeneração, pois considera a área na sua importância lúdico cultural:

A vegetação arbórea dada a sua franca descaracterização e pela sua atual composição não é significativa, em se tratando de complexo fisionômico do Cerrado. Poder-se-ia protegê-la com o intuito de sua regeneração mas, no entanto, restringir-se-ia a área para o desenvolvimento de atividades de lazer para as crianças e jovens de baixa renda, bem como todo o gado teria que de lá ser retirado (MINAS GERAIS, Apelação Cível no 1.0024.03.971351-6/001, 2008d, p. 9).

Sob o argumento do segundo relatório, um primeiro juiz posicionou-se pela não ocorrência de danos ambientais, afirmando que "diante da prova produzida nos autos, tem-se, pois, que embora o fato inequívoco do acidente, inexiste repercussão ambiental/danos ambientais de tal decorrentes e que mereçam atenção ou recuperação" (MINAS GERAIS, Apelação Cível n 1.0024.03.971351-6/001, 2008d, p.12).

Com base nos resultados do primeiro relatório (da qual se acrescentaram outros), um segundo juiz considera "efetiva constatação de danos ambientais":

Cumpre observar que os danos ambientais foram devidamente constatados em vistorias realizadas pela FEAM, IBAMA, IEF e Polícia Florestal. Constou dos referidos laudos: a queima de vegetação rasteira e árvores de pequeno e grande porte, ocorrida em área de preservação permanente, causada pela queima do diesel derramado dos vagões que descarrilaram; a existência de resíduo do óleo derramado no solo nos arredores do acidente e, ainda manchas de óleo derramado no leito do Córrego do Cachorro Magro, que deságua no Ribeirão Arrudas e, posteriormente, no Rio das Velhas.

Não desconheço que a empresa ré promoveu diversas medidas para a contenção do óleo derramado, mitigação dos efeitos da queima e retirada 
dos resíduos do solo e do córrego. Inclusive, tais medidas foram salientadas pelo ilustre Perito Oficial.

No entanto, tais medidas apenas diminuíram a proporção dos danos ambientais verificados, que poderiam ser bem maiores do que os ocorridos, sem, contudo, afastá-los de todo (MINAS GERAIS, Apelação Cível no 1.0024.03.971351-6/001, 2008d, p. 17-18).

O desmatamento por corte raso sem destoca de 0,5 hectares de floresta estacional semidecídua em Carandaí - MG no ano de 2001 levou à condenação do proprietário a indenização por danos morais ambientais. O fato considerado como dano ambiental, contudo, foi menos o corte ilegal ocorrido - este relevante obviamente - e mais a lesão ao equilíbrio ecológico, aos valores ecológicos da comunidade. Diz o julgador: "no caso em tela, o dano moral é significativo e caracteriza-se por lesão ao valor ecológico da coletividade (...). O dano ambiental consiste na degradação do equilíbrio ecológico" (MINAS GERAIS, apelação cível n 1.0132.05.002117-0/001, 2008e, p. 6-13).

Neste caso, o juiz adota a teoria de que o dano moral ambiental não se liga a pessoa determinada dada sua natureza transindividual difusa.

\footnotetext{
Trata-se de um Direito fundamental, intergeracional, intercomunitário, constitucionalmente garantido e ligado ao Direito da personalidade, posto que diz respeito à qualidade de vida da comunidade (...).

O meio ambiente ecologicamente equilibrado é um dos bens e valores indispensáveis à personalidade humana, considerado essencial à sadia qualidade de vida, portanto, à dignidade social. A existência de um ambiente salubre e ecologicamente equilibrado representa condição especial para um completo desenvolvimento da personalidade humana (...).

O dano extrapatrimonial não surge apenas em consequência da dor, em seu sentido moral de mágoa, mas também do desrespeito a valores que afetam negativamente a coletividade (MINAS GERAIS, Apelação Cível $\mathrm{n}^{\circ}$ 1.0132.05.002117-0/001, 2008e, p. 5).
}

Nas conclusões do voto, afirma o relator do processo: "e, justamente pelo enorme período em que a sociedade ficará desprovida do recurso natural que justifica a imposição de indenização pelo dano moral coletivo, do qual se insurge o apelante" (MINAS GERAIS, Apelação Cível n 1.0132.05.002117-0/001, 2008e, p.12).

Muitos casos tratam da averbação da reserva legal em propriedade rural. Normalmente, o Ministério Público pleita indenização por danos morais ambientais pela não averbação da reserva legal no cartório de registro de imóveis (no cadastro ambiental rural - C.A.R., pela legislação posterior); a jurisprudência, porém, nega dano ambiental pelo simples fato da não inscrição da área legal no registro imobiliário. 
Assevera determinado juiz sobre a não averbação: "deve ser ressaltado, nesse passo, que a mera ausência de formalização da reserva legal não dá azo à conclusão de que a comentada área de preservação tenha suportado ilegal degradação ambiental" (MINAS GERAIS, Apelação Cível n 1.0702.11.0412831/001, 2014f, p. 12).

No mesmo diapasão: "do mesmo modo, não há qualquer evidência quanto à ocorrência de dano moral coletivo ou dano moral decorrente da não averbação de reserva legal” (MINAS GERAIS, Apelação Cível nº 1.0702.11.045745-5/001, 2015c, p. 17).

Em conclusão, temos que foram encerradas como dano ambiental e deram base para dano moral ambiental agressões ao meio natural, seja poluição d'água ou do ar, erosões do solo, aprisionamento de pássaros silvestres, etc. 


\section{O PAÇO MUNICIPAL DE POÇOS DE CALDAS}

\subsection{ASPECTOS GEOGRÁFICOS GERAIS DA ÁREA.}

Poços de Caldas está localizado no sul de Minas Gerais e faz divisa com o estado de São Paulo (Mapa 1). Sua origem e localização estão relacionados a existência de fontes de águas termais em seu território, fruto de processos hidrogeológicos ocorridos na região.

Mapa 1 - Localização geográfica do município de Poços de Caldas/MG

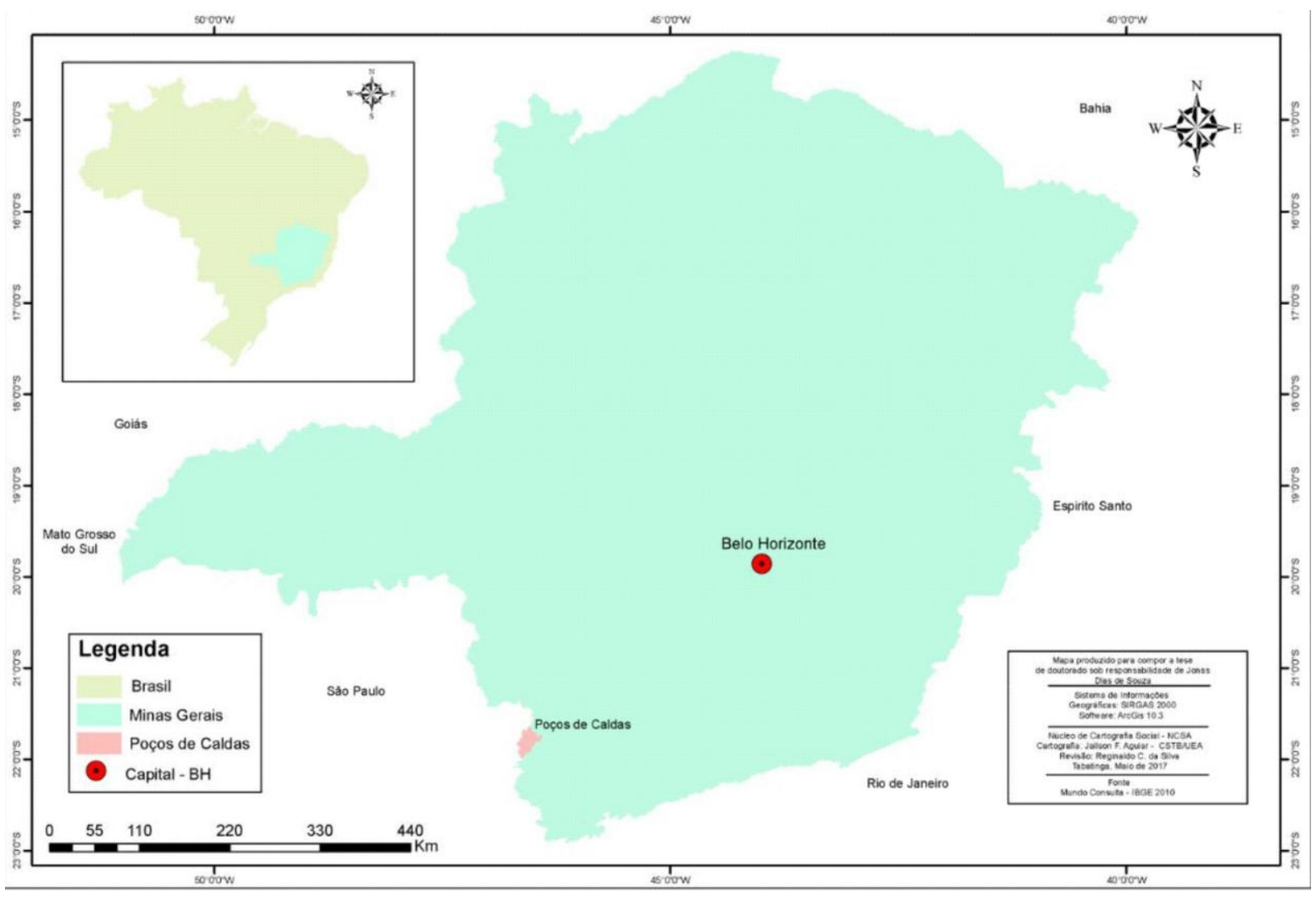

Fonte: IBGE, 2010. Elaborado por Jailson F. Aguiar, 2017.

O município aproveitou as fontes de água termal para promover o crescimento e desenvolvimento da cidade, aliando terapia hidrotermal com a exploração de jogos de azar. Ainda no final do século XIX e na primeira metade do século XX, projetos urbanos para a cidade foram elaborados e aplicados, culminando numa urbanização planejada do centro da cidade e na construção de grandes hotéis, cassinos e 
balneários. Atualmente, a cidade aproveita o potencial do turismo termal como um dos eixos econômicos do município.

A área escolhida pela Comissão Especial para receber o Paço Municipal localiza-se na zona sul de Poços de Caldas. O local escolhido foi, contudo, logo questionado por uma série de organizações e associações da sociedade civil devido às características naturais da área, dando origem a uma ação civil pública proposta pelo Ministério Público de Minas Gerais. As discussões no processo versaram principalmente sobre a exigência ou não de licenciamento ambiental para o empreendimento e o órgão competente para expedir o documento, mas no fundo questionava-se a própria área escolhida para abrigar o Paço.

$\mathrm{Na}$ zona sul da cidade, o Paço Municipal estaria localizado dentro da subbacia do ribeirão das Vargens (Mapa 2). A sub-bacia possui área de aproximadamente $42,45 \mathrm{Km}^{2}$, sendo o ribeirão afluente do ribeirão das Antas, este tributário do rio Pardo, na bacia do rio Grande.

Mapa 2 - Localização da sub-bacia do ribeirão das Vargens

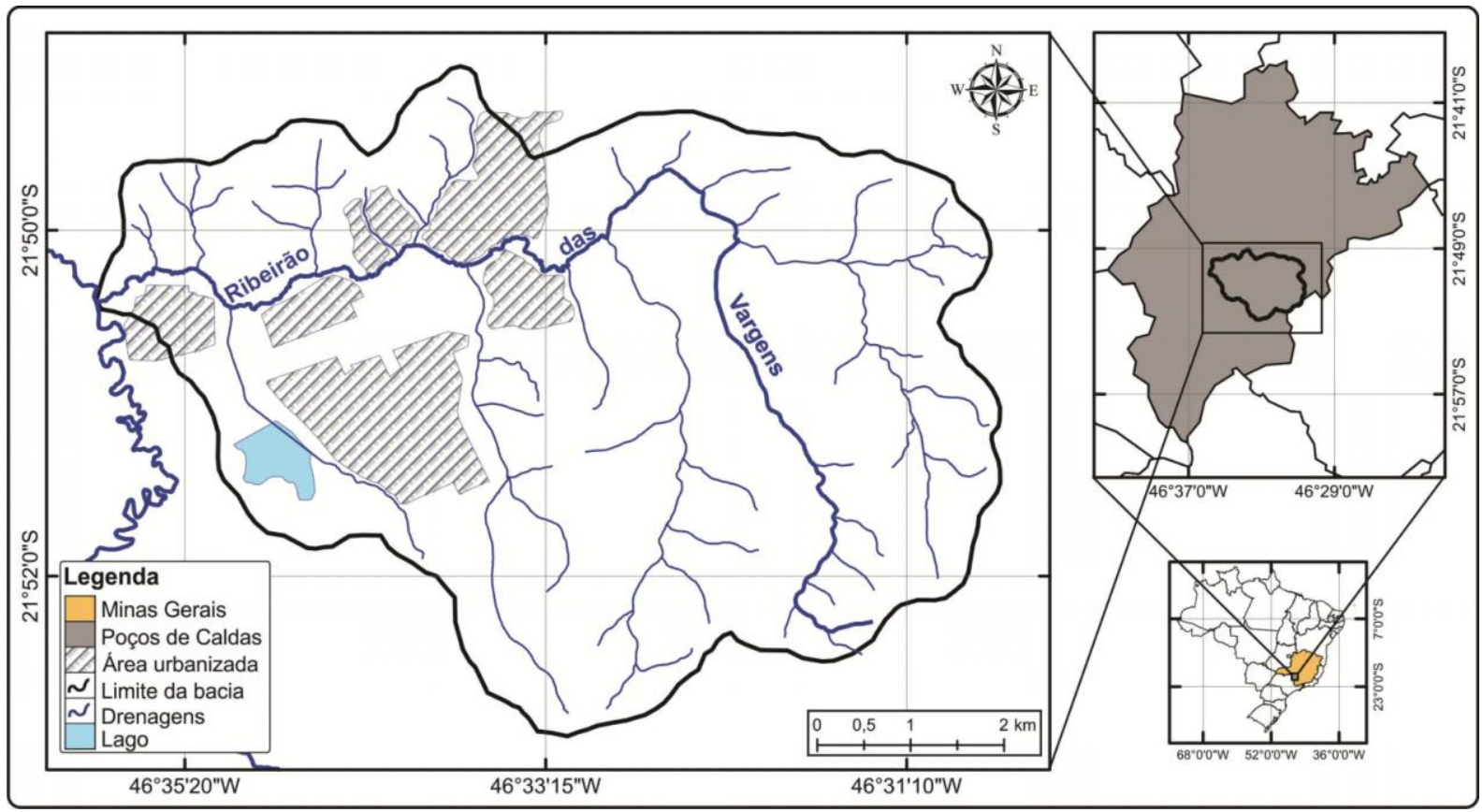

Elaborado por: Gilbey Pereira, 2017.

Historicamente, a região conheceu as primeiras ocupações urbanas ainda na década de 60 do século XX. A urbanização expandiu-se durante as décadas de 70 e 80 com a implantação dos loteamentos Jardim Kennedy I (1966), Jardim Kennedy II 
(1970), Jardim Esperança (1979), Cohab Eng. Pedro Affonso Junqueira (1979), Parque das Nações (1980) e Jardim Paraíso (1984), ocupação composta sobretudo de famílias de baixa renda.

Os loteamentos ocuparam área a jusante da sub-bacia, assentando-se sobre planícies aluviais, colinas de topo aplainado e cristas de colinas, em terreno recoberto por depósitos colúvio-eluviais de natureza argilosa e argilo-siltosa (os pacotes argilosos alcançam 9,5 $\mathrm{m}$ a 15,5 $\mathrm{m}$ de profundidade) (POÇOS DE CALDAS; GOERCIEX, 2010).

As características naturais da sub-bacia do ribeirão das Vargens a tornam sensível às atividades humanas aí desenvolvidas, especialmente quanto às formas de ocupação e atividades potencialmente poluidoras. A construção do Paço Municipal não fugiu às preocupações ambientais: receava-se que as intervenções humanas pudessem alterar quantitativamente a circulação das águas, bem como qualitativamente suas caracterísitcas físico-químicas.

Isto porque, em termos hidrogeológicos, a sub-bacia do ribeirão das Vargens faz parte do complexo sistema de infiltração e circulação profunda de água que abastece os aquíferos superficiais e profundos da região. Quer dizer, regionalmente, a sub-bacia do ribeirão das Vargens, em função do sistema de circulação e armazenamento d'água subterrânea, é considerada área de recarga dos aquíferos superficiais e profundos, aquíferos responsáveis tanto pelo fornecimento público de água quanto pela existência das fontes de águas termais na cidade.

A área da sub-bacia do ribeirão das Vargens, assim como todo o terreno do município, é cortada por falhas e fraturas que comandam os fluxos superficiais e subsuperficiais e determinam o armazenamento da água subterrânea. As fraturas e falhas foram geradas durante o processo de formação do Maciço Alcalino de Poços de Caldas em consequência da ascenção e pressão do magma intrusivo sobre as rochas cristalinas encaixantes, reativando antigas falhas ou gerando novas fissuras no terreno, as quais condicionam a circulação e armazenamento d’água na região.

A ocorrência de água subterrânea na região de Poços de Caldas está condicionada, principalmente, aos sistemas de fraturamento desenvolvidos sobre as rochas do Complexo Alcalino. Especificamente, a circulação e o armazenamento das águas subterrâneas hipotermais e termais estão restritos ao sistema aqüífero fraturado ou fissurado, cabendo aos aqüíferos granulares superficiais apenas parte da restituição relativa as águas de temperaturas normais. A infiltração, o escoamento e 0 
armazenamento das águas subterrâneas processam-se através das descontinuidades criadas ou reativadas pelos eventos tectônicos que afetaram a chaminé alcalina (COMIG, 2001, p. 36).

As fraturas coincidem frequentemente com o leito dos cursos d'água: o curso do córrego Vai-e-Volta, por exemplo, está ajustado à linha de fratura de direção N14트 enquanto o ribeirão de Poços coincide com a fratura de direção E-W.

Em relação ao armazenamento d'água em subsuperfície, três zonas aquíferas são identificadas. Uma primeira criada pelo sistema de fraturas que controla o sistema de circulação profunda e atinge em torno de três mil metros. Uma segunda zona aquífera está também associada ao fissuramento do terreno, mas alcança profundidades mais modestas, de cem a duzentos metros de profundidade. A terceira zona aquífera é uma zona aquífera rasa do tipo granular e atinge profundidades de até trinta metros.

Na sub-bacia do Ribeirão das Vargens, a água subterrânea está associada ao aquífero granular, de circulação rasa, e ao aquífero intermediário, de circulação mais profunda (GORCIEX, 2010). A linha de fraturamento de direção N14ํE, porém, alcança a sub-bacia do ribeirão das Vargens e a torna área de recarga do aquífero profundo responsável pela ocorrência das fontes hidrotermais do município.

Sobre as áreas de recarga dos aquíferos profundos, o Estudo Hidrogeoambiental sobre a Estância Hidromineral de Poços de Caldas, elaborado pela COMIG (Companhia Mineradora de Minas Gerais), afirma:

A recarga dos aquíferos do Planalto de Poços de Caldas se dá por infiltração direta nas fraturas que controlam a rede de drenagem superficial ou "per decensum", através dos sedimentos e manto de alteração das rochas alcalinas. Assim, as principais áreas de recarga estão na serra de São Domingos e nos vales dos ribeirão da Serra e do córrego Vai e Volta, coincidindo com a área mais urbanizada do maciço alcalino da cidade de Poços de Caldas (COMIG, 2001, p. 11).

Noutro trecho complementa:

Todo o leito do ribeirão Vai-e-Volta é encaixado e controlado por uma dessas fraturas N14으. Essa estrutura, possivelmente, constitui-se em uma zona preferencial de recarga que se prolonga até 0 vale do ribeirão das Vargens, com o qual se intercomunicaria pelas fraturas que transpõem 0 divisor de águas superficiais. O lineamento de direção $\mathrm{E}-\mathrm{W}$ coincide com $\mathrm{o}$ curso dos ribeirões dos Poços/Serra e se interconecta com os outros traços de fraturas secundárias, em direção à serra de São Domingos que, inequivocamente, constitui-se em outra zona de recarga.

As fontes do conjunto Pedro Botelho e dos Macacos são o resultado da interseção de três sistemas de fraturas, todos controlando direções de drenagens que influem decisivamente na recarga dos aqüíferos sotopostos aos de natureza granular. A recarga é proveniente, na maior parte, da 
precipitação pluviométrica que ocorre dentro da bacia hidrográfica do ribeirão de Caldas, mas, pode ser complementada por contribuições de fendas profundas que interconectam as bacias hidrográficas do córrego Vai e Volta com o ribeirão das Vargens, aumentando substancialmente a área de contribuição (COMIG, 2001, p. 36).

Apesar das condições naturais particulares da sub-bacia do ribeirão das Vargens, dispositivos legais de salvaguarda ambiental do sistema hidrogeológico só aparecem de forma definida a partir do Plano Diretor de 1992.

No Plano de Desenvolvimento Integrado de Poços de Caldas (PDI) de 1970/71, aprovado pela Lei 2.056/1973, as condições naturais gerais do território municipal não eram colocadas como restritivas ou condicionantes à atividade humana; por outro lado, o zoneamento proposto (mapa 3) também não alcança a sub-bacia do ribeirão das Vargens (SOUZA, 2012). 
Mapa 3 - Zoneamento municipal de 1970

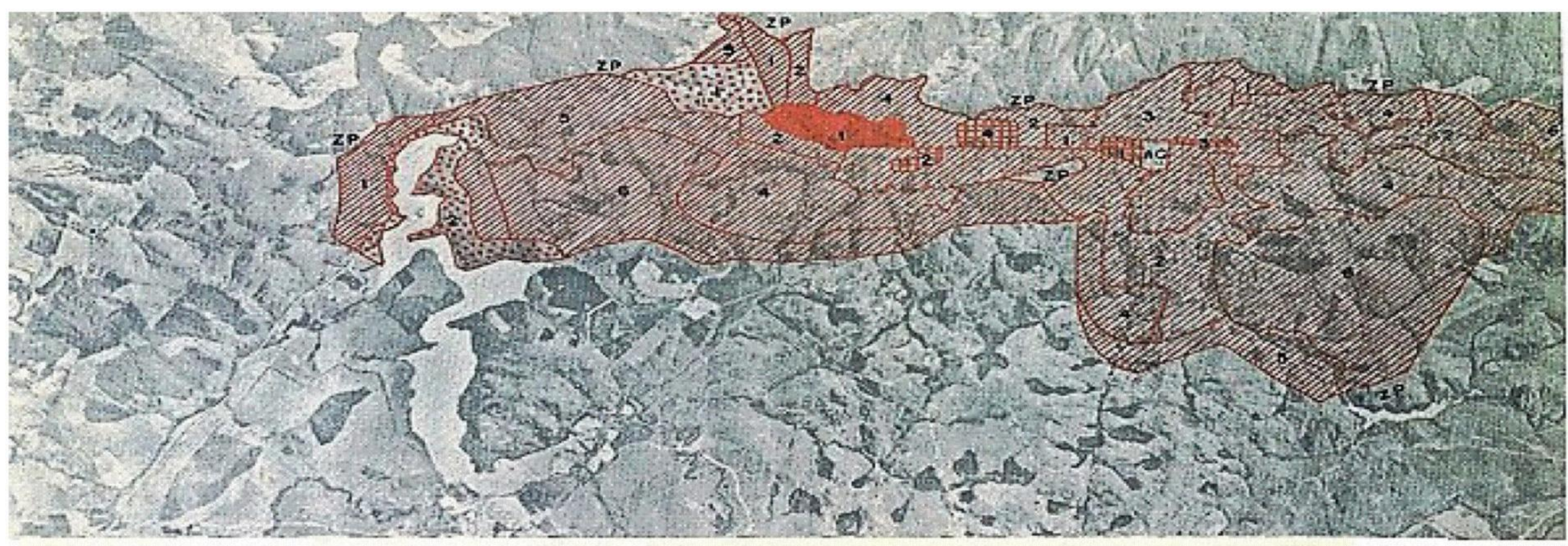

\section{LEGENDA}

$\begin{array}{llll}\text { ZT - ZONA TURISTICA } & \mathscr{Z} & \text { ZH - ZONA HABITACIONAL } \\ \text { AC - ÁREA CENTRAL } & \text { ZP - ZONA DE PROTEÇĀO } \\ \text { 国田 ZE - ZONA ESPECIAL } & \square & \text { ZI - ZONA INDUSTRIAL }\end{array}$

I SEM ESCALA

Fonte: Poços de Caldas. Plano de Desenvolvimento Integrado de Poços de Caldas, 1970 
Nem a Lei de Parcelamento do Solo de 1976 (Lei 2.420/76) regulava - de alguma forma direta e especificamente - os loteamentos e lotes frente a questões ambientais, permitindo, do contrário, o arruamento dos terrenos baixos, alagadiços ou sujeitos a inundações, desde que fossem drenados e aterrados (art. $8^{\circ}$ ). Ademais, a Lei 2.420/1976 nada dizia da reserva de áreas verdes nos loteamentos.

Em 1985, a nova lei de parcelamento do solo de Poços de Caldas, Lei Municipal $n^{\circ}$ 3.639/1985, proíbe parcelamentos em áreas non aedificandi, consideradas essas as faixas marginais ao longo de águas correntes e dormentes e áreas de preservação natural, histórica, paisagística, bem como as áreas consideradas de segurança. A lei 3.639/1985 também prevê reserva de áreas verdes nos loteamentos, numa razão de 12\% do total (Lei oㅡ 3.639/1985, art. 5ํe e 9 ).

Editada a lei municipal 5.488/1994 que aprova o Plano Diretor de Poços de Caldas, a preocupação com a preservação dos aquíferos, mananciais e fontes d'água fica evidenciada, embora o Plano receie a falta de trabalhos científicos que permitam conhecer o desempenho das atividades humanas frente ao meio físico existente (POÇOS DE CALDAS, 1992, p. 188).

Desse modo, são instituídas mais zonas de preservação permanente no zoneamento municipal, voltadas para a proteção de áreas responsáveis pela recarga dos aquíferos (lei 5.488/1994, art. 5) e proposto o controle da execução de loteamentos em áreas de mananciais (lei 5.488/1994, art. 22).

Em relação à zona sul, especificamente, o macrozoneamento do Plano Diretor de 92 divide a região em Zona Rural Agrícola (ZRA) e Zona de Proteção de Mananciais (ZRP; mapa 4).

A primeira ocupa maior parte da área e é destinada ao incentivo e instalação de produção agrícola primária. A área também se destina ao incentivo de atividades extrativas, estando vinculado, porém, a proteção dos recursos naturais porquanto submetido a controle, monitoramento e fiscalização das atividades por parte do município visando a recuperação das áreas atingidas, a proteção da cobertura vegetal e a preservação dos cursos d'água (Lei 5.488/1994, art. 5ํㅡ, inciso III, 3). 
Mapa 4 - Macrozoneamento municipal de Poços de Caldas - 1992

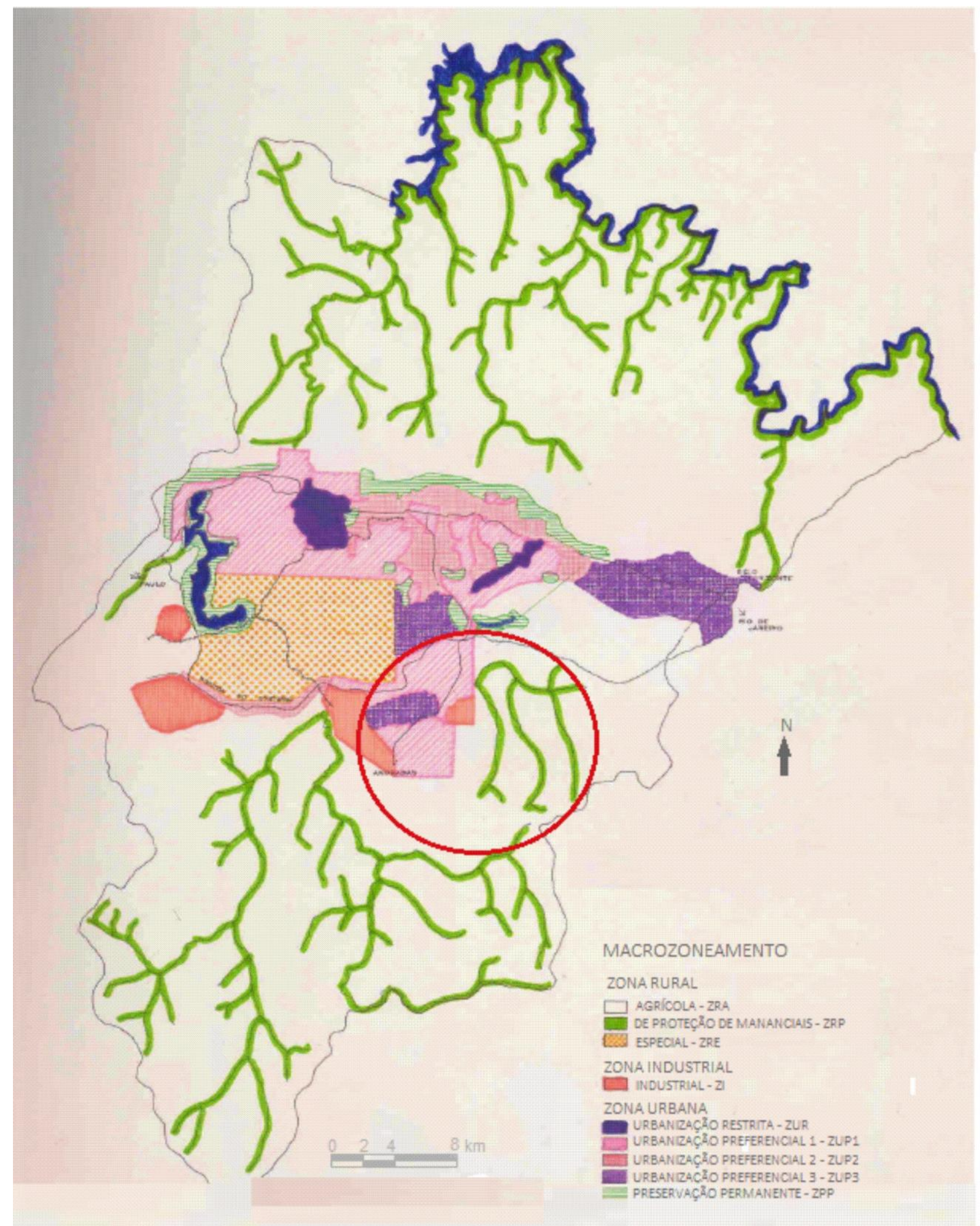

O círculo vermelho destaca a zona sul de Poços de Caldas.

Fonte: Poços de Caldas. Plano Diretor de Poços de Caldas, 1992. 
A proteção ambiental é reforçada com a ZRP que qualifica parte do terreno como de preservação e proteção dos cursos d'água, especialmente nas cabeceiras dos mananciais de abastecimento (Lei 5.488/1994, art. 5o, inciso III, 1).

O Plano veda ainda o parcelamento do solo para fins urbanos, tanto na Zona Rural Agrícola quanto nas Zonas de Proteção de Mananciais (Lei 5.488/1994, art. 6ㅇ).

A proteção ambiental fica por conta também da delimitação, na zona sul, de uma zona de urbanização restrita, classe do zoneamento cujo objetivo era desestimular a ocupação urbana em função da proteção de mananciais, rios e preservação de encostas, e da zona de urbanização preferencial 1, que permite ocupações urbanas com restrições quanto ao adensamento face aos interesses de preservação ambiental.

Na revisão feita no Plano Diretor em 2006, promovido pela Lei Complementar no 74 de 2006, a qualificação da área muda inicialmente para Zona Rural de Proteção Ambiental (ZRPA) (mapa 5) definida como áreas de alto grau de proteção ambiental, caracterizadas como bacias de mananciais de abastecimento de água, não admitidos parcelamento do solo para fins urbanos, com rigoroso controle de intervenções antrópicas e limitações ao uso e ocupação do solo, cuja instalação deve ser precedida de licenciamento para avaliação de impacto ambiental (Lei Complementar 74/2006, art. 6--A, inciso IX).

Existem alguns trechos classificados como Zona de Preservação Permanente (ZPP) onde não é permitido ocupação em função das suas características físicas e ambientais (Lei Complementar 74/2006, art. 6-A, inciso I).

Na mesma lei que revisou o Plano Diretor, disposições expressas em relação ao controle do adensamento e impermeabilização em bacias de recarga de aquíferos hídricos e termais são introduzidas na política de macrozoneamento e zoneamento urbano (L. C. № 74, art. 5을 ). E nas diretrizes da política de meio ambiente figura a adoção de parâmetros urbanísticos que ampliem as condições de permeabilização nas bacias do ribeirão da Serra, do córrego Vai-e-Volta e do córrego das Pitangueiras (Lei Complementar ํㅡㄴ 74, art. 22, e). 
Mapa 5 - Zoneamento municipal de Poços de Caldas, 2006

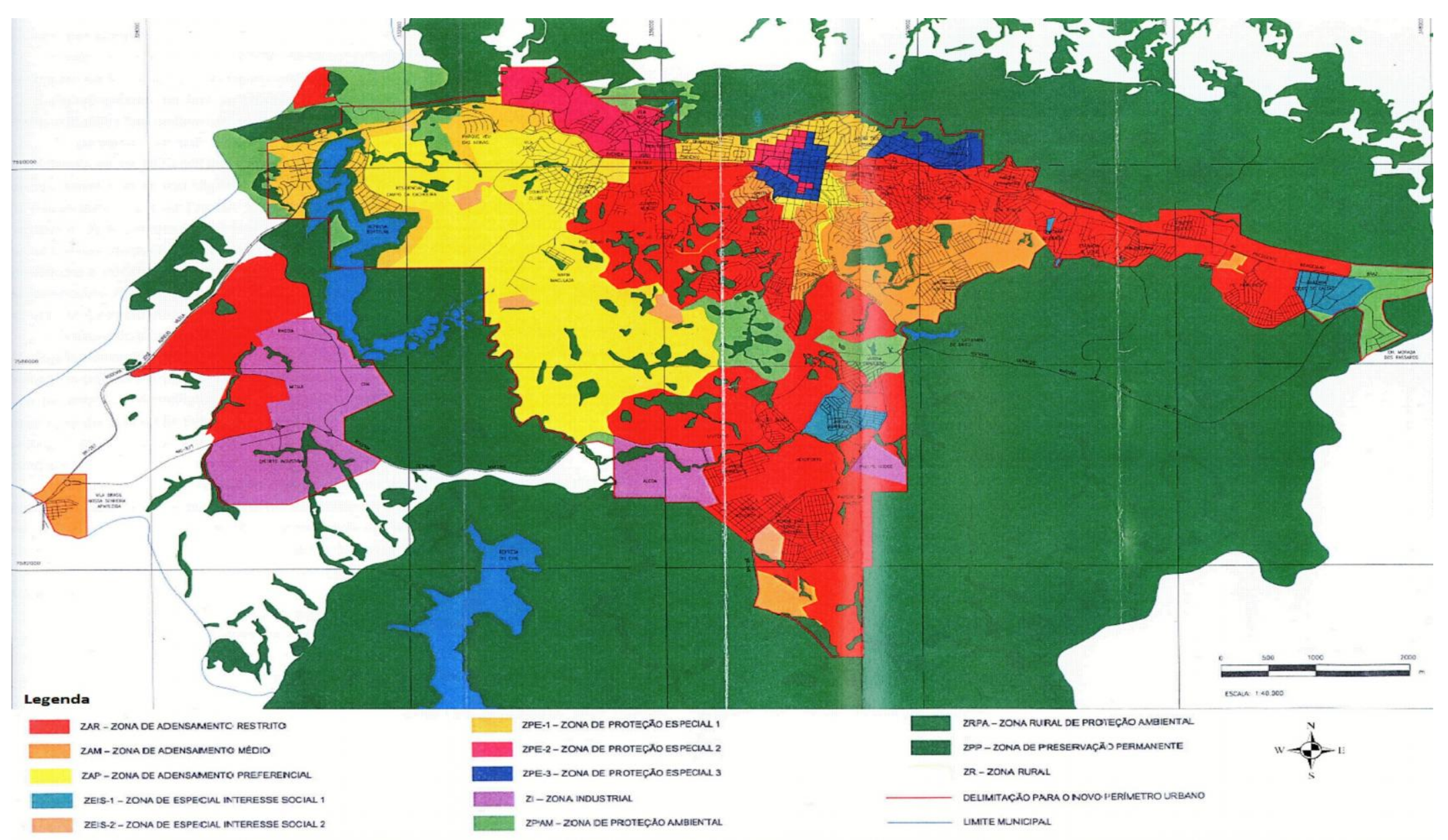

Fonte: Poços de Caldas. Lei Complementar no 74/2006. 
Na sub-bacia do ribeirão das Vargens, a proteção ambiental também está inserida nos parâmetros da zona de adensamento restrito (antiga zona de urbanização restrita), que compreende áreas caracterizadas como áreas de recarga dos aquíferos hídricos e termais ou com necessidade de controle do escoamento superficial (Lei complementar ํㅜ 74, art. 6으. AV). As construções nesta zona foram submetidas também a novos padrões urbanísticos que visam dar efetividade aos objetivos do zoneamento, como o coeficiente de aproveitamento (relação entre a área total construída e a área total do terreno), taxa de ocupação máxima do terreno, taxa mínima de permeabilidade e área mínima para os lotes (art. 6A).

A sub-bacia do ribeirão das Vargens, enfim, ganhou densidade normativa no que se refere à proteção das condições naturais da área a partir do Plano Diretor de 1992 com vistas a preservar, sobretudo, os processos hidrogeológicos (escoamento d'água superficial, infiltração e circulação d'água subterrânea, capacidade de recarga dos aquíferos, etc.).

Os parcelamentos do solo na área para fins de loteamento urbanos, porém, são na maioria anteriores à legislação municipal que protegeu as características naturais da área, não obedecendo, assim, aos parâmetros urbanísticos ambientais dispostos na lei.

A área urbana ocupa aproximadamente $12 \%$ da área total da bacia (GORCIEX, 2010), mas os loteamentos localizam-se em porção sensível em termos de enchente e alagamento, como comprovam as frequentes inundações do bairro Jardim Kennedy II.

Com efeito, em análise morfométrica da sub-bacia do ribeirão das Vargens, Sampaio et al. (2016) concluíram que parte considerável dos assentamentos encontram-se sobre as planícies fluviais do curso principal da bacia e em terreno de baixa declividade, de 0 a $3 \%$, "o que reduz a velocidade do escoamento superficial e favorece a deposição de sedimentos que se acumulam no leito das drenagens e potencializam a chance de ocorrência de cheias" (SAMPAIO, 2016, p. 241).

É possível que os perigos de enchentes talvez só não sejam maiores devido ao volume de lotes vagos (mapa 6) e o baixo coeficiente de aproveitamento (mapa 7) praticado na bacia em questão (quanto menor o coeficiente, menor a relação entre a área construída e a área total do terreno. Na sub-bacia predominam lotes com coeficiente de aproveitamento de 0 a $1 \%$ ). 
Mapa 6 - Lotes vagos no município de Poços de Caldas

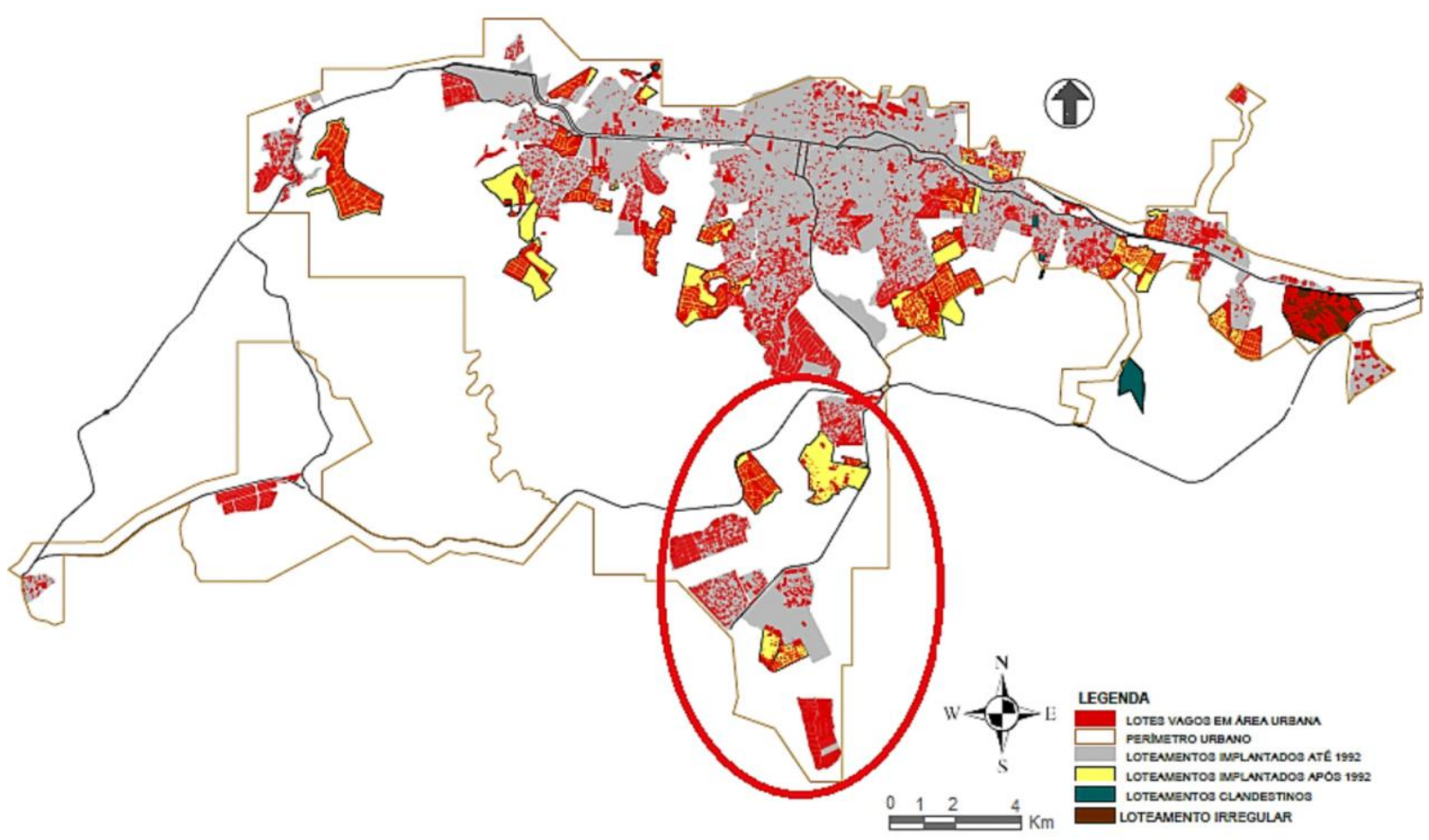

Em destaque, no círculo vermelho, a zona sul da cidade.

Fonte: Exatus 2006

Mapa 7 - Coeficiente de aproveitamento praticado nos lotes em Poços de Caldas

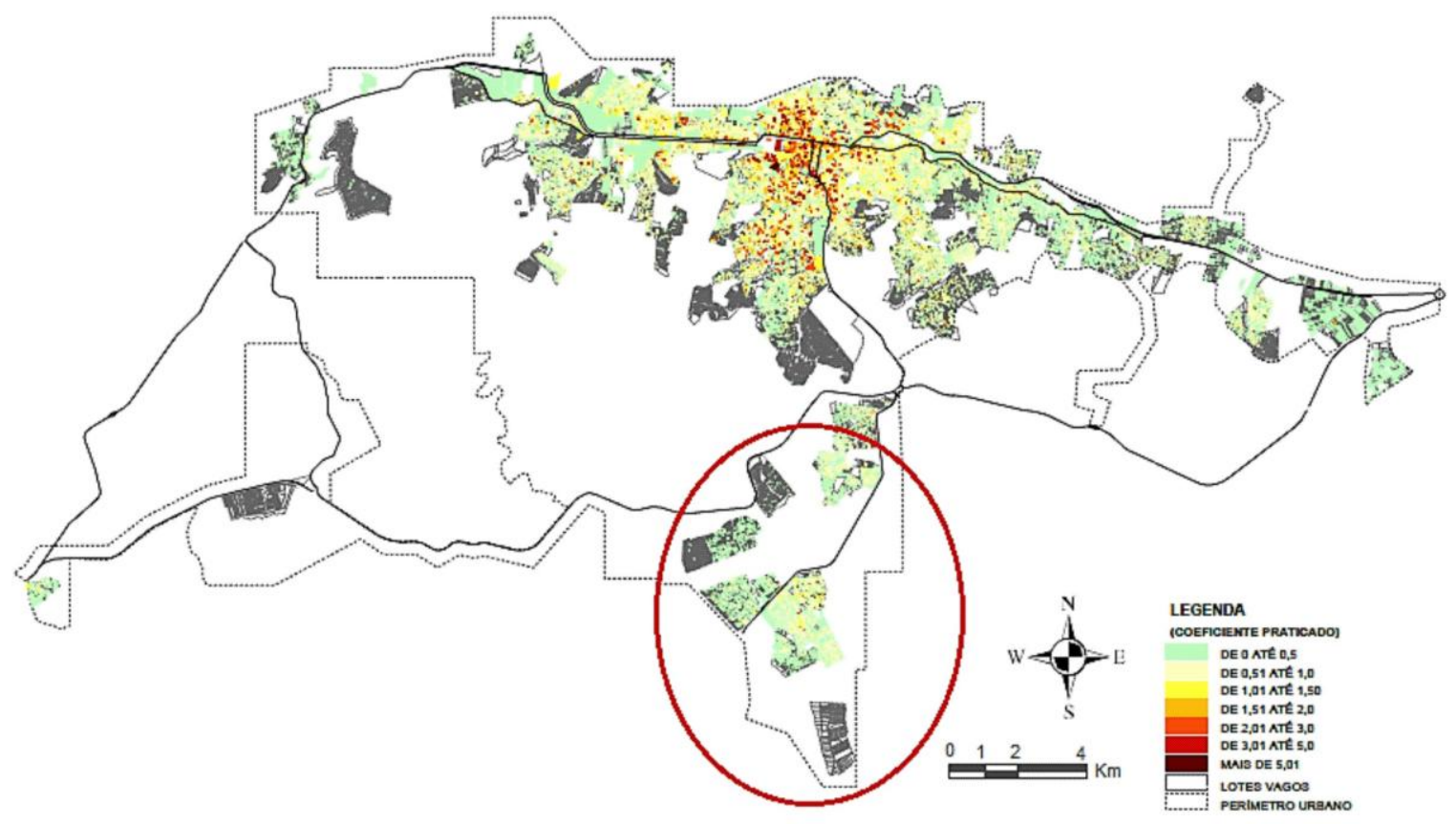

Em destaque, no círculo vermelho, a zona sul da cidade.

Fonte: Exatus 2006 
Além dos usos urbanos, a sub-bacia do ribeirão das Vargens encerra também usos industriais, agropecuários, áreas verdes e de preservação permanente, configurando um ambiente onde a ação antrópica se estende por toda a bacia.

Segundo o mapa de uso e ocupação do solo elaborado pela Fundação Gorciex (2010) (mapa 8), existem lavras de mineração na porção central e extremo leste da sub-bacia, perfazendo um total de 90 hectares, e solos expostos por atividades de aterro ou processos erosivos (121 hectares), na porção centro oeste da bacia. Área considerável também é usada por lavouras de milho, num total de 252 hectares, ocupando manchas na parte oriental da bacia.

Mapa 8 - Uso e ocupação do solo praticado na sub-bacia do ribeirão das Vargens, Poços de Caldas

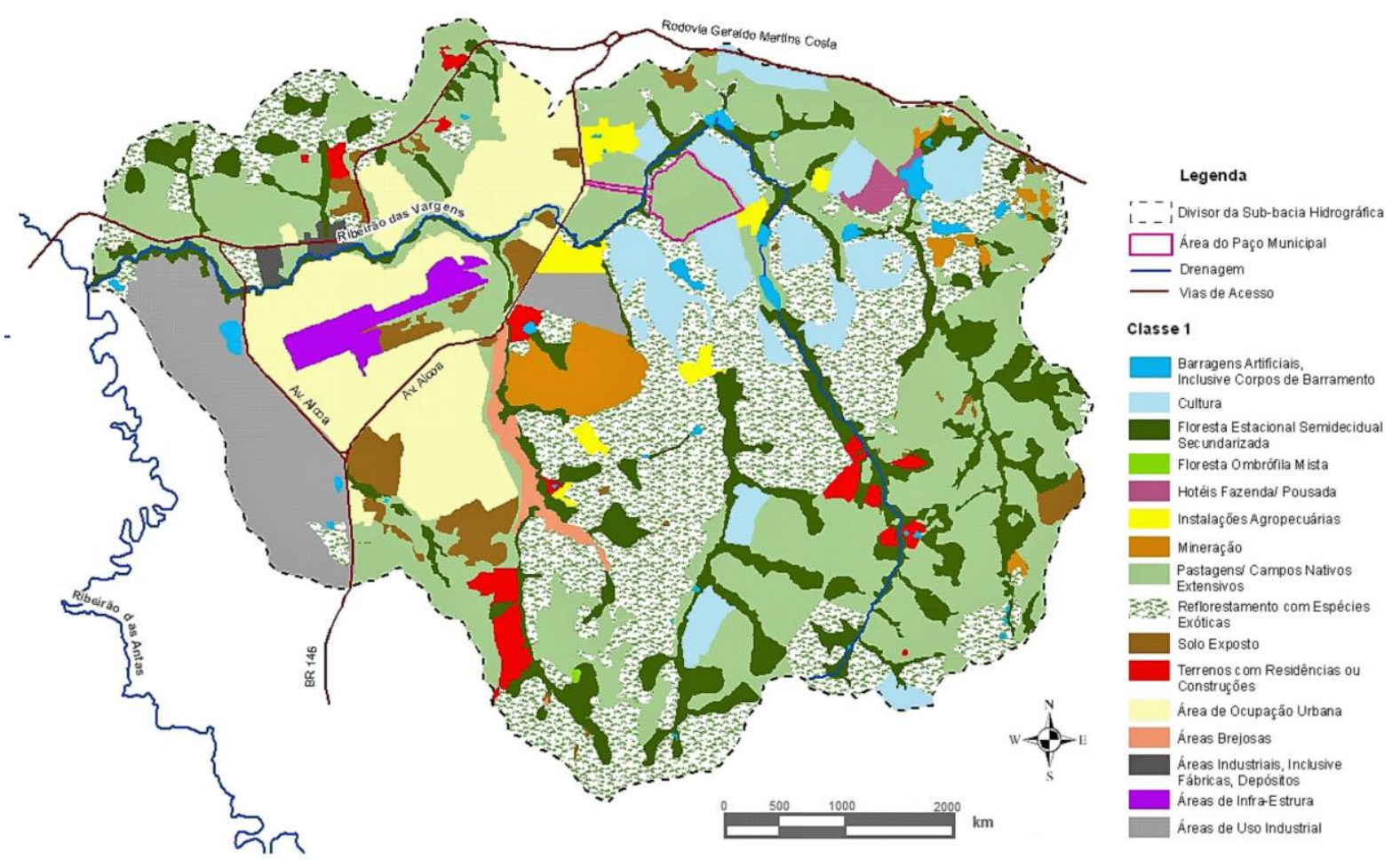

Fonte: GORCIEX, 2010.

$\mathrm{Na}$ borda interior dos divisores de água, margeando os limites internos da sub-bacia, ocorrem formações vegetais características de áreas onde ocorreu intervenção na vegetação natural, categorizados como pasto sujo (1.086 hectares), e pastagens nativas de uso extensivo (114 hectares). 
Os ambientes classificados como naturais incluem floresta estacional semidecidual secundarizada (capoeirinha, capoeira, capoeirão), floresta ombrófila mista, ou floresta de araucária, reflorestamento com espécies exóticas, e biótopos úmidos como barragens artificiais e áreas brejosas. Esses usos ocupam um total de 1067 hectares dentro da sub-bacia. O ambiente natural, entretanto, como ressalva o estudo da Fundação Gorciex, é consideravelmente alterado pela atividade humana, demonstrando alto grau de intervenção antrópica na área.

O desenvolvimento de atividades humanas notadamente observadas na
área em questão descaracterizou drasticamente a cobertura vegetal original,
da qual restam escassos remanescentes, em sua maioria profundamente
alterados. O resultado disso é que, ao longo de toda a Sub-Bacia
Hidrográfica do Ribeirão das Vargens predominam diferentes fases de
sucessão vegetal, dentre elas (capoeirinha, capoeira e capoeirão). Essas
faixas de vegetação são entremeadas principalmente por pastagens,
reflorestamento com espécies exóticas e monoculturas, principalmente
milharais (GORCIEX, 2010, p. 170).

O meio ecológico da sub-bacia do ribeirão das Vargens encontra-se, enfim, já impregnado da presença humana. Os parcelamentos do solo, a ocupação do terreno com moradias e atividades industriais, a introdução de sistemas de drenagem, distribuição e coleta d'água fazem parte do conjunto de sistemas técnicos que se agregam à dinâmica do meio ecológico e dão a medida da profundidade das alterações ambientais processadas. Ao mesmo tempo, a legislação municipal define o caráter ambiental da área ao destacar proteger os processos e elementos naturais da bacia, imprimindo valores ambientais a região.

\subsection{ESCOLHA DA ÁREA PARA IMPLANTAÇÃO DO PAÇO MUNICIPAL}

O objetivo do projeto de implantação de um Paço Municipal em Poços de Caldas foi reunir os vários órgãos públicos em um único lugar, atualmente espalhados pela cidade com alto custo de aluguéis, facilitando o acesso e otimizando a administração pela concentração das atividades num mesmo local. $O$ Paço Municipal compreenderia a instalação do Poder Executivo, Legislativo e Cidade Judiciária, um Centro de Convenções e órgãos de apoio e atividades correlatas (GORCIEX, 2010). 
A ideia da implantação de um centro cívico $^{19}$ foi aventada ainda no Plano de Desenvolvimento Integrado da década de 70. O Plano indicava a zona oeste da cidade como local de implantação do centro cívico, visando promover o adensamento nesta região.

No Plano Diretor de 1992, o projeto de um centro cívico municipal foi considerado como um dos eixos para a estruturação do espaço urbano e para a distribuição das atividades econômicas. O Plano indicava, na época, a Zona de Urbanização Preferencial 3, na zona oeste da cidade (ver mapa 3), como de preferência para localização da área a ser adquirida para instalação do centro cívico, entendendo este como "equipamento indutor de urbanização" (POÇOS DE CALDAS, 1992, p. 216). Outra região foi escolhida, contudo.

Em 2006, foi nomeada uma Comissão Especial (Decreto no 8.536/2006) responsável pela análise dos aspectos urbanísticos e dos custos estimados da área onde seria implantado o Paço Municipal. Foram consideradas inicialmente seis áreas para implantação do projeto (Tabela 1; mapa 9). As áreas foram identificadas a princípio procurando atender as regiões indicadas no Plano Diretor de 1992 para adensamento e expansão urbana, assim como a disponibilidade de área, com boa topografia e condições para expansão futura, e áreas cujos proprietários manifestaram interesse de doação. As áreas selecionadas inicialmente foram:

Tabela 1 - Áreas selecionadas para abrigar o Paço Municipal

\begin{tabular}{|c|c|}
\hline Área & Localização \\
\hline A1 & Próxima ao Country Club, ao lado da garagem municipal. \\
\hline $\mathrm{A} 2$ & $\begin{array}{l}\text { Entre e ao lado do almoxarifado do Departamento Municipal de Eletricidade (DME) e o Shopping } \\
\text { Center Minas Sul }\end{array}$ \\
\hline A3 & Próxima ao trevo de acesso à empresa Mitsui com acesso à Rodovia José Aurélio Vilela - BR 267 \\
\hline A4 & Retiro dos Carneiros e aproximadamente 2 km após o Conjunto Habitacional Maria Imaculada \\
\hline A5 & Entre a Av. Liliza Ottoni, a Subestação Furnas e a Represa Bortolan \\
\hline A6 & Entre a estrada de acesso ao Santuário da Mãe Rainha e a Av. Alcoa \\
\hline
\end{tabular}

19 Centro cívico é o termo usado pelo Plano de Desenvolvimento Integrado de 1970 e na Lei $5.488 / 1994$ e refere-se à área ou região onde se concentram órgãos e entidades da administração pública. O termo Paço Municipal passa a ser usado na Lei 5.488/1994 com a redação dada pela Lei Complementar no 74 e refere-se a local ou edifício usado pela administração pública para suas atividades. 
Para a escolha da área que abrigaria o Paço Municipal, foi empregada técnica de escolha baseada em análise multicriterial, elencados os seguintes fatores: I) distância geográfica média ponderada; II) facilidade de acesso; III) topografia do terreno; IV) disponibilidade de área para expansão e; V) custo com infraestrutura e aquisição da área. Os resultados foram analisados utilizando lógica comparativa pareada, denominada Processo Analítico Hierárquico (PAH).

Os fatores elencados na análise multicriterial atendiam aos seguintes interesses: custo baixo do terreno e disponibilidade de expansão; localização equidistante entre os loteamentos da cidade; condições do relevo que minimizassem os custos das edificações e vias de acesso; custos com a implantação de sistema viário e ampliações e melhorias nas vias existentes (POÇOS DE CALDAS, 2006a, p. 11; GORCIEX, 2010, p. 8).

Das seis áreas indicadas e após discussão dos membros da comissão, votouse entre três áreas selecionadas (Áreas 1, 4 e 6), segundo a pontuação atingida pelo processo analítico (tabelas 2, 3, 4 e 5). Foram obtidas as seguintes classificações:

Tabela 2 - Pontuação para fator distância geográfica média ponderada

\begin{tabular}{|c|c|c|}
\hline Áreas & $\begin{array}{c}\text { Distância geográfica média } \\
\text { ponderada }\end{array}$ & Pontuação \\
\hline Área 1 & 4409 & 10,00 \\
\hline Área 4 & 5850 & 7,54 \\
\hline Área 6 & 4788 & 9,21 \\
\hline
\end{tabular}

Fonte: Poços de Caldas, 2006a; GORCIEX, 2010.

Tabela 3 - Ponderação e pontuação final, considerando custos de desapropriação e construção de vias

\begin{tabular}{|c|c|c|c|c|c|c|}
\hline & $\begin{array}{c}\text { Distância } \\
\text { geográfica } \\
\text { média } \\
\text { ponderada }\end{array}$ & Acesso & Topografia & $\begin{array}{l}\text { Disponibilidade de } \\
\text { área para expansão }\end{array}$ & Custo & $\begin{array}{l}\text { Pontuação } \\
\text { ponderada }\end{array}$ \\
\hline Peso & 0,344 & 0,300 & 0,122 & 0,122 & 0,111 & --- \\
\hline Área 1 & 10,00 & 7,00 & 4,00 & 3,00 & 5,06 & 6,96 \\
\hline Área 4 & 7,54 & 6,33 & 9,00 & 10,00 & 2,09 & 7,04 \\
\hline Área 6 & 9,21 & 8,33 & 10,00 & 5,50 & 10,00 & 8,67 \\
\hline
\end{tabular}

Fonte: Poços de Caldas, 2006a; GORCIEX, 2010. 
Tabela 4 - Ponderação e pontuação final, suprimindo os custos de desapropriação das áreas 4 e 6

\begin{tabular}{|c|c|c|c|c|c|c|}
\hline & $\begin{array}{l}\text { Distância } \\
\text { geográfica } \\
\text { média } \\
\text { ponderada }\end{array}$ & Acesso & Topografia & $\begin{array}{c}\text { Disponibilidade de } \\
\text { área para } \\
\text { expansão }\end{array}$ & Custo & $\begin{array}{l}\text { Pontuação } \\
\text { ponderada }\end{array}$ \\
\hline Peso & 0,344 & 0,300 & 0,122 & 0,122 & 0,111 & --- \\
\hline ÁREA 1 & 10,00 & 7,00 & 4,00 & 3,00 & $\begin{array}{c}2,66 \\
(3,57)\end{array}$ & 6,69 \\
\hline ÁREA 4 & 7,54 & 6,33 & 9,00 & 10,00 & $\begin{array}{c}1,13 \\
(1,52)\end{array}$ & 6,94 \\
\hline ÁREA 6 & 9,21 & 8,33 & 10,00 & 5,50 & $\begin{array}{c}5,26 \\
(10,00)\end{array}$ & 8,14 \\
\hline
\end{tabular}

Fonte: Poços de Caldas, 2006a; GORCIEX, 2010.

Tabela 5 - Ponderação e pontuação final, suprimindo os custos de desapropriação das áreas 4 e 6 e construção de vias das áreas 1 e 4

\begin{tabular}{|c|c|c|c|c|c|c|}
\hline & $\begin{array}{c}\text { Distância } \\
\text { geográfica } \\
\begin{array}{c}\text { média } \\
\text { monderada }\end{array}\end{array}$ & Acesso & Topografia & $\begin{array}{c}\text { Disponibilidade } \\
\text { de área para } \\
\text { expansão }\end{array}$ & Custo & $\begin{array}{c}\text { Pontuação } \\
\text { ponderada }\end{array}$ \\
\hline Peso & 0,344 & 0,300 & 0,122 & 0,122 & 0,111 & --- \\
\hline ÁREA 1 & 10,00 & 7,00 & 4,00 & 3,00 & 10,00 & 7,50 \\
\hline ÁREA 4 & 7,54 & 6,33 & 9,00 & 10,00 & 0,25 & 6,84 \\
\hline ÁREA 6 & 9,21 & 8,33 & 10,00 & 5,50 & 0,10 & 7,57 \\
\hline
\end{tabular}

Fonte: Poços de Caldas, 2006a; GORCIEX, 2010.

Talvez prevendo a série de questionamentos que seriam feitos à implantação do projeto na área escolhida, a Comissão Técnica salientou que a construção do Paço deveria observar os dispositivos legais que preservassem a ocupação da região sul e que o projeto do Paço previsse dispositivos de contenção de águas pluviais e permeabilização do solo (POÇOS DE CALDAS, 2006).

A escolha final da Comissão Especial recaiu, na verdade, sobre área inserida às cinco primeiras áreas selecionadas, não constando o terreno 6 do primeiro estudo técnico para definição da área para implantação do Paço Municipal. A inclusão foi feita por sugestão de membro da Comissão Especial, Sr. João José Ferreira (então secretário municipal de administração) com o argumento de que "o fato de não se considerar área na zona sul, implicará em perda de oportunidade de se beneficiar a população da zona sul" (POÇOS DE CALDAS, 2006, s/n), sendo a sugestão depois acolhida pelo presidente. Um segundo estudo técnico foi elaborado e finalmente a área 6 foi selecionada. 
Ainda em 2006, foi realizada revisão do Plano Diretor pela Lei Complementar no 74, onde as diretrizes da política de estruturação do espaço urbano (art. 23) buscavam viabilizar a implantação do Paço Municipal, sem rever ou indicar, contudo, a localização dada pelo Plano Diretor anterior. A Lei Complementar deixa em aberto tal questão, pois permite a inserção da área onde seria instalado o paço municipal no perímetro urbano, se fosse o caso (Lei Complementar 74 de 2006, art. 23, inciso X).

Por fim, a Lei Complementar no 84 de 2007 estabelece o novo perímetro urbano e indica a área 5 (correspondente à área 6 dos Estudos Técnicos) para a instalação do Paço, visando contemplar a escolha realizada pela Comissão Especial.

\subsection{QUALIFICAÇÕES LEGAIS DA ÁREA}

Do conflito de interesses envolvendo a construção do Paço Municipal, identificam-se diferentes qualificações envolvendo a área escolhida. São posições não necessariamente antagônicas, mas que dão peso a certos atributos em preferência a outros.

I - Comissão Técnica de Parcelamento, Uso e Ocupação do Solo e Planejamento Urbano

A qualificação da área localizada na sub-bacia do ribeirão das Vargens resultou da quantificação dos cinco fatores intervenientes acima mencionados. Todos os fatores foram previamente selecionados e receberam pontuação conforme os aspectos pertinentes a cada um, formando uma matriz de dados base da análise multicriterial. Assim, por exemplo, no tocante ao fator acesso, recebeu maior pontuação a área que apresentava melhor condição de: I) proximidade com os eixos viários principais; II) facilidade de localização e; III) facilidade de deslocamento após investimentos em infraestruturas. Em relação ao fator custo, os valores estimados de desapropriação, implantação de sistema de abastecimento e tratamento de água e esgoto e implantação do sistema viário foram pontuados segundo fórmula matemática que considerou o valor inverso entre pontuação e custo (quanto maior o valor, menor a pontuação e vice-versa).

As áreas inicialmente escolhidas foram, portanto, qualificadas conforme critério matemático de classificação segundo os fatores previamente selecionados - 
fatores que destacavam sobretudo as qualidades econômicas da área. A sub-bacia do ribeirão das Vargens, assim como as outras áreas, tiveram suas características transformadas em dados numéricos, mesuráveis e comparáveis, sendo a localização do Paço subordinada à melhor classificação dentro da matriz de avaliação.

\section{II - Comissão Especial}

Embora fundamentada nos estudos da Comissão Técnica, a Comissão Especial responsável pela escolha da área onde seria implantado o Paço Municipal destacou mais a função que o Paço Municipal exerceria do que a melhor combinação de fatores elencados e matematicamente ponderados.

A Comissão Especial definiu a área supondo um bom atendimento à população que o Paço deveria oferecer e tentando favorecer socialmente a região sul da cidade. Na ata de reunião da Comissão Especial, consta que:

\footnotetext{
De um modo geral, a impressão da maioria dos membros da Comissão Especial, foi no sentido de que o Paço Municipal não deveria ser usado como indutor de crescimento da cidade, mas sim para bem atender a seus usuários, além do que a localização do Paço na zona sul representará importante equipamento público para valorizar socialmente toda aquela região, atraindo novos padrões de uso e ocupação e proporcionando expressiva melhoria na qualidade de vida da população adjacente (POÇOS DE CALDAS, 2006, s/n).
}

Apesar dos debates nas reuniões versarem sobre todos os fatores intervenientes e a votação se dar dentro do quadro classificatório promovido pelo estudo da Comissão Técnica, a qualificação da área realizada pela Comissão Especial deu-se em função das qualidades do Paço, quer dizer, se no Estudo Técnico a localização do Paço está em função da qualidade fatorial da área (distância geográfica, acesso, custo, etc.), na Comissão Especial é a área que está subordinada às funções do Paço, qual seja, de bem atender a população e valorizar socialmente a zona sul da cidade.

\section{III - Ministério Público de Minas Gerais}

Em 2011, O Ministério Público (MP) propôs ação civil pública em face do estado de Minas Gerais e do município de Poços de Caldas contra a instalação do Paço Municipal no local selecionado pela Comissão Especial. Na petição inicial, os fundamentos fáticos que embasaram os pedidos do MP versavam principalmente sobre as características ambientais da área e a necessidade legal de licenciamento 
ambiental para o empreendimento. Pede o Parquet que o município interrompa as atividades de intervenção na área e que o estado de Minas Gerais assuma a regularização ambiental através do licenciamento. Pede também, dada as características naturais, que a Zona Rural de Proteção Ambiental seja declarada e reconhecida judicialmente como espaço territorial especialmente protegido.

Na petição inicial, nos pressupostos fáticos do pedido, o Ministério Público elenca os argumentos de diversas associações da sociedade civil organizada, no sentido de ressaltar a qualidade ambiental da área em apreço como local de recarga dos aquíferos e de mananciais de abastecimento. São, desse modo, trazidos aos fundamentos fáticos da petição inicial os argumentos da Associação Ambiental do Sul de Minas Gerais (AASMIG - ONG Mãos da Terra); do Comitê de Bacia Hidrográfica dos Afluentes Mineiros dos Rios Mogi-Guaçu e Pardo (CBH - MogiGuaçu Pardo); do Instituto de Arquitetos do Brasil (IAB); da Agência para o Desenvolvimento Integrado do Sul e Sudoeste de Minas Gerais (ADISMIG); da Associação das Empresas de Loteamento e Desenvolvimento Urbano de Poços de Caldas (AELO); da Associação Sulmineira de Engenharia, Arquitetura e Agronomia (ASEAA); da ONG Planeta Solidário; do Sindicato da Indústria da Construção Civil de Poços de Caldas (SINDUSCON) e do CREA Poços de Caldas. O Ministério Público também valeu-se do relatório produzido por técnicos do próprio órgão, o Centro de Apoio Técnico do Ministério Público (CEAT) e o estudo elaborado pela Fundação Gorceix e encomendado pela prefeitura municipal como Estudo de Impacto Ambiental para o empreendimento.

Os trabalhos realizados por essas entidades sublinham principalmente as fragilidades ambientais da área escolhida para instalação do Paço Municipal e os perigos ou ilegalidades de aumentar o perímetro urbano sobre a Zona Rural de Proteção Ambiental. Subentende-se que a região que abrigaria o Paço Municipal tem uma qualidade ambiental intrínseca pela função de área de recarga dos aquíferos que desempenha e pelos mananciais de abastecimento que encerra.

"Desde a elaboração do primeiro Plano Diretor da cidade de Poços de Caldas a área (...) é considerada como área de proteção ambiental" diz o relatório produzido pelo Comitê de Bacia Hidrográfica dos Rios Mogi-Guaçu e Pardo citado pelo MINISTÉRIO PÚBLICO (2011 p.9). O Córrego Várzea de Caldas é zona de recarga de água, lembram a AELO, a ASEAA, o SINDUSCON, a Ong Planeta Solidário e o CREA Poços de Caldas. Segundo a AASMIG, a instalação do Paço no local 
determinado será feita em área de proteção ambiental e de mananciais (MINISTÉRIO PÚBLICO, 2011).

Já o estudo da Fundação Gorceix é de matriz negativa, considera o Ministério Público, quer dizer, os impactos ambientais apontados pelo estudo são na sua maioria negativos (alteração da paisagem, supressão de solo agrícola, alteração da qualidade das águas superficiais e subterrâneas, aumento da suscetibilidade à erosão, alteração das propriedade do solo, alteração da área de recarga, etc.).

Nos pressupostos jurídicos, a subsunção das caracteríticas locais é feita, consequentemente, em termos ambientais. O Ministério Público lembra do Direito Constitucional de todos ao meio ambiente ecologicamente equilibrado que impõe ao administrador público a observância do meio ambiente na salvaguarda dos sistemas naturais e da biodiversidade (MINISTÉRIO PÚBLICO, 2011, p. 40). São levantados também o artigo 170 da Lei Orgânica Municipal e o artigo $2^{\circ}$ da Lei Complementar $n^{\circ}$ 84/2007 como fundamentos para a exigência do licenciamento ambiental.

Os argumentos do Ministério Público, em suma, apoiam-se na caracterização ambiental da área, especialmente sua delimitação enquanto zona rural de proteção ambiental.

\section{IV - PODER JUDICIÁRIO}

A sentença que julgou a Ação Civil Pública promovida pelo Ministério Público mineiro, contudo, indeferiu os pedidos feitos.

$\mathrm{Na}$ decisão, o magistrado vale-se do mesmo estudo elaborado pela Fundação Gorceix e usado pelo Ministério Público para fundamentar os perdidos da ação para assumir o não impacto ambiental causado pelo empreendimento. A decisão cita trecho do estudo onde se afirma:

\footnotetext{
Assim, sob o ponto de vista em análise de impacto para o empreendimento, a construção do Paço Municipal no local pretendido, não constitui problemas para o ambiente e a população da cidade, devendo contudo serem conduzidas medidas compensatórias com o intuito de melhorar a sua condição ambiental, em curto, médio e longo prazos (MINAS GERAIS, 2011, p. 3).
}

Sob esse argumento, a sentença ampara-se, então, nas competências do CONAMA para negar o pedido de liminar, especialmente na competência de determinar a realização de estudos das alternativas e das possíveis consequências ambientais de projetos públicos e privados no caso de obras ou atividades de 
significativa degradação ambiental, especialmente nas áreas consideradas

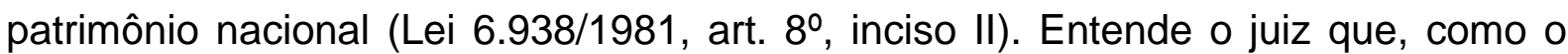
Paço não causaria danos ambientais nem se encontra em área considerada de patrimônio nacional, não há fundamentos para deferimento da liminar.

Decide e conclui a juíza:

Ao contexto das disposições transcritas, considerando que não se trata de local de patrimônio nacional ou de instalações de atividades efetivas ou potenciais poluidoras, em análise dos Estudos realizados (...) de modo que não já norma cogente ao objeto da liminar (...) não desprezando o interesse maior da coletividade e de medidas compensatórias, em caráter mitigador ao intuito de melhorar a condição ambiental, quando já enfatizado pelo Estudo do local que não constitui problemas de meio ambiente e a população da cidade (MINAS GERAIS, 2011 p. 6).

Recorrida a sentença, o processo segue para o Tribunal de Justiça de Minas Gerais. No relatório da decisão, lembra o magistrado os argumentos e pedidos do Ministério Público e as contrarrazões apresentadas pelo estado de Minas Gerais e pelo município de Poços de Caldas, salientando que "tanto a parte autora, quanto a parte ré instruiu o feito com diversos documentos consistentes em estudo ambiental, o primeiro no sentido de inviabilidade do empreendimento, e, o segundo, no sentido de sua adequação" (MINAS GERAIS, 2016, p. 13-14).

Para averiguar a exigência do licenciamento ambiental e o ente federativo responsável pela sua emissão, a decisão em $2^{\circ}$ grau fundamenta-se na extensão do dano ambiental decorrente da intervenção humana. Por ser um dano local, o magistrado conclui pela regularidade do projeto e a legalidade dos atos praticados pelo poder público municipal.

Embora o mérito das decisões esteja na legalidade dos atos praticados pelo poder público municipal e na obrigatoriedade e órgão competente para expedir o licenciamento ambiental, a sub-bacia do ribeirão das Vargens é tomada em termos naturais enquanto degradação e danos ambientais. No horizonte do discurso da justiça são os elementos naturais, nomeadamente os processos hidrogeológicos de circulação e armazenamento d’água, que traduzem a qualificação dada à região. 


\section{DISCUSSÃO DOS RESULTADOS}

Como situar a regulamentação levada a cabo pelo Direito Ambiental dentro da relação ecumenal do homem com a superfície terrestre? De que forma os princípios e conceitos informativos da interpretação e aplicação das normas ambientais e a jurisprudência do Tribunal de Justiça de Minas Gerais podem ser encarados frente à compreensão da substância ecológica, técnica e simbólica que envolve a presença humana na Terra?

A análise do material pesquisado neste trabalho permite especificar o Direito Ambiental em razão: I) do conteúdo conotativo do meio ambiente; II) da totalização homogeneizante de suas características; III) da construção jurídica da realidade geográfica e; IV) da participação a identidade subjetiva e material da paisagem.

\subsection{MEIO AMBIENTE ENQUANTO NATUREZA}

No horizonte da hipótese levantada no começo do trabalho, mostram a doutrina e jurisprudência pesquisadas uma naturalização do meio ambiente? Tem o Direito Ambiental tomado o meio ambiente precipuamente na sua dimensão natural e ecológica, apesar do conceito abrangente defendido pela doutrina?

O conjunto da doutrina selecionada e a sistematização da jurisprudência do Tribunal mineiro mostrou, realmente, um meio ambiente que se refere, sobretudo, às águas, aos rios, ao ar, solo, à vegetação e à fauna, os quais fazem ressaltar o conteúdo natural do meio ambiente, a natureza que o constitui. Em outras palavras, o meio ambiente acaba se assentando sob uma base ecológica ou natural da realidade.

Com efeito, há uma tendência, no geral, de definir os princípios e conceitos apenas quanto aos aspectos naturais, embora a definição legal de meio ambiente tente conjugar homem e natureza. Fala-se, essencialmente, em florestas, paisagens, diversidade biológica, flora, processos ecológicos e funções naturais do meio. É assim que Machado (2010) refere-se ao princípio da qualidade de vida, ao princípio do acesso equitativo aos recursos naturais e ao princípio da informação.

O princípio do meio ambiente ecologicamente equilibrado, outro exemplo, é definido "do ponto de vista ecológico" e relaciona-se à "conservação das propriedades e funções naturais desse meio" (MACHADO, 2010). Ademais, vincula- 
se a ideia de "ambiente saudável" à noção de ambiente "ecologicamente equilibrado" unicamente (MILARÉ, 2013).

Quanto à qualidade ambiental, mesmo Derani (2001), ao interpretar a qualidade de vida como ampliação do sentido dado pela economia, dá a entender que, embora o meio ambiente não diga respeito à "natureza isolada" e se vincule a produção, trabalho e lazer do homem, as condições externas de bem-estar do homem referem-se aos elementos naturais tais como "um ar puro e de uma bela paisagem".

Se pensarmos no princípio do desenvolvimento sustentável veremos, por um lado, a tentativa de equalização das atividades humanas face ao uso dos recursos naturais, mas, por outro, da forma como está definida, ele reproduz a visão do meio ambiente como natureza.

Desse modo, ao mesmo tempo em que se procura evitar os efeitos deletérios da atividade antrópica sobre o meio ambiente, este é entendido como um ecossistema que possui certa resiliência (taxa de suporte) e capacidade de renovação material (WEISS, 2005; WINTER, 2005; FIORILLO, 2013 SIRVINSKAS, 2016).

Assim também no que se refere ao princípios da capacidade de suporte (ANTUNES, 2013), ao princípio do limite (SIRVINSKAS, 2016) e aos princípios da precaução e da prevenção. A atividade econômica, segundo tais princípios, pode ser desenvolvida até o limite dos ecossistemas, de forma que eles tenham capacidade de suportar as novas entradas de matéria e energia. Caso reste dúvida quando aos impactos, prevalece o in dubio pro natura (ANTUNES, 2013) ou o in dubio pro ambiente (SIRVINSKAS, 2016).

Percebe-se um reforço dessa tendência em naturalizar o meio ambiente quando avaliamos os conceitos do Direito Ambiental. De fato, os conceitos de Direito Ambiental nos trazem ainda mais perto de uma dimensão natural do meio ambiente, completando o sentido dos princípios enumerados.

Vale começar pelo termo ecossistema, expressão muito usada em outras definições. Sirvinskas (2016) diz que é a ecologia que nos fornece o conceito de ecossistema e, nesse sentido, temos que lembrar, na história da ecologia um dos fundamentos do ecossistema é a aplicação dos conceitos e métodos da física, da matemática e da química na descrição dos fluxos energéticos e materiais entre a biocenose e o biótopo (ACOT, 1990; WORSTER, 1994). 
Cunhado em 1935 por Tansley, o conceito de ecossistema permitiu integrar os fatores físicos à biocenose mediante a medição dos valores energéticos que circulam na cadeia trófica. Os métodos, os modelos e a linguagem mecanicistas passam a descrever as interações entre biótopo e biocenose, analisados agora sob uma mesma matriz metodológica (ACOT, 1990).

Segundo Donaldo Worster, o objetivo de Tansley era afastar a ecologia da influência da filosofia organicista e das comparações da natureza com as comunidades humanas. "Tansley queria purgar da ecologia tudo que não fosse sujeito de quantificação e análise" assevera Worster: "ele a recuperaria do seu status de um mistério vago, um ponto de vista moralizante" (WORSTER, 1994, p. 301). Tansley, então, propôs um novo modelo de organização da natureza: o ecossistema.

\footnotetext{
Usando o ecossistema, todas as relações entre organismos podem ser descritas em termos de trocas energéticas puramente materiais e substâncias químicas como água, fósforo, nitrogênio, e outros nutrientes que são os constitutivos da "comida" (...). O ecossistema de Tansley trouxe toda natureza - rochas e gases bem como a biota - dentro de uma ordem comum de recursos materiais (WORSTER, 1994, p.302).
}

Deslocada para o Direito Ambiental, a doutrina não parece se afastar deste entendimento cunhado na ecologia. Inexiste interpretação sistemática que adapte o conceito ecológico de ecossistema à ideia de meio ambiente natural e humano. Novamente encontramos nas definições doutrinárias de ecossistema referência a elementos da natureza como fauna, flora, solo, água, etc. (SILVA, 2009; ANTUNES, 2013; SIRVINSKAS, 2016).

A ideia de ecossistema irradia-se, por outro lado, também na definição de outros conceitos, a exemplo de processos ecológicos essenciais, equilíbrio ecológico e mesmo em diversidade biológica, recursos ambientais ou espaços territoriais especialmente protegidos.

Equilíbrio ecológico são os fatores do ecossistema ou habitat em equilíbrio (MACHADO, 2010), a regulação e manutenção da biota, com seus fluxos de matéria, energia e informações genéticas (MILARÉ, 2013) e a harmonia entre os bens que compõe a biota (SIRVINSKAS, 2016).

Já na expressão processos ecológicos essenciais podemos encontrar um conceito "eminentemente ecológico" (SIRVINSKAS, 2016) voltado à preservação e restauração de uma "estrutura natural mínima" (ANTUNES, 2013), a qual cabe ao Poder Público assegurar. Processos ecológicos essenciais são, essencialmente, o 
transporte e transformação da energia e matéria que ocorrem entre os elementos biótico e abióticos (MILARÉ, 2013).

A doutrina brasileira usa frequentemente a expressão recursos ambientais. $\mathrm{Na}$ lei 9.985/2000, contudo, ela é definida em termos puramente naturais porquanto denota o solo, a atmosfera, as águas, a fauna e a flora. A preservação, recuperação e restauração dos recursos naturais (ou outro bem ambiental interesse de proteção) é também definido na lei tendo em vista os ecossistemas, a diversidade biológica e os processos ecológicos essenciais. E é este o sentido que predomina, pois a doutrina não amplia substancialmente o significado dado pelo texto da lei.

Os espaços territoriais especialmente protegidos, por fim, também são postos em termos de ecossistema. Historicamente, a defesa dos espaços especialmente protegidos já mantinha fortes vínculos com a proteção da natureza e dos elementos propriamente naturais. Nesse sentido, cabe reproduzir aqui, a citação, trazida por Milaré, de Miguel Sereduik Milano, sobre a evolução histórica e conceitual de áreas protegidas. Diz Milano ${ }^{20}$ :

desde o início da criação das primeiras áreas protegidas, as preocupações com a conservação da natureza evoluíram, transcendendo o conceito original, um tanto emocional, de área silvestre. Além de preservar belezas cênicas e bucólicos ambientes históricos para as gerações futuras, as áreas protegidas assumiram objetivos, como a proteção de recursos hídricos, manejo de recursos naturais, desenvolvimento de pesquisas científicas, manutenção do equilíbrio climático e ecológico, preservação dos recursos genéticos, e, atualmente, constituem o eixo da estruturação da preservação in situ da biodiversidade como um todo (MILANO, 2001 apud MILARÉ, 2013, p. 183).

$\mathrm{Na}$ definição hodierna, eles objetivam proteger os ecossistemas que os compõem (SILVA, 2009; MILARÉ, 2013; SIRVINSKAS, 2016). Tal situação fica mais evidente, é verdade, nas definições das unidades de conservação de proteção integral em comparação com as de uso sustentável, uma vez que estas incluem a preocupação com as populações tradicionais e o uso sustentável que se fazem das áreas. Entretanto, a importância das características naturais relevantes de tais áreas é que ditam as atividades permitidas no local, pois, natureza não se confunde nem se integra à dimensão humana.

${ }^{20}$ MILANO, M.S. 2001. Unidades de Conservação - Técnica, Lei e Ética para a Conservação da Biodiversidade. In: In: BENJAMIN, A.H. (org.) Direito Ambiental das Áreas Protegidas. Rio de Janeiro: Ed. Forense Universitária, 2001, p. 03-41. 
O sentido atribuído ao termo poluição, devemos ponderar na mesma direção, pois também engloba aspectos sociais e não somente aqueles referentes à natureza: as leis mais atuais, com efeito, incluem questões de saúde humana, segurança e bem-estar das populações, mostrando que meio ambiente não se reduz aos elementos da natureza (solo, água, atmosfera, etc.).

$O$ argumento aqui desenvolvido, contudo, sem demérito nenhum aos autores de Direito Ambiental e suas contribuições doutrinárias, é que se configura nas leis e nos discurso da doutrina a imagem de um meio ambiente essencialmente natural; isto é, a impressão dominante no conjunto dos princípios e conceitos, da forma como são trabalhados pela doutrina, é de um meio ambiente ocupando uma esfera separada, apartada da esfera humana, dele não fazendo parte as relações e processos sociais.

Efetivamente, o homem é quem desestabiliza o equilíbrio ecológico, desorganiza os processos ecológicos essenciais, quem põe em risco a biodiversidade, causa poluição, sendo necessários territórios especiais, reservas legais ou áreas de preservação permanente para proteger as características naturais do meio. O uso do termo restaurar, per si, nos remete à ideia de processos ecológicos existentes antes do homem, a um meio ambiente que se constitui sem o homem, algo como um "mito moderno da natureza intocada" (DIEGUES, 2004).

Falta nas pertinentes considerações ecológicas do meio ambiente sua devida integração com a dimensão social enquanto elemento de apreensão histórica, simbólica e de manipulação tecnológica. A caracterização ambiental em termos naturais tem sentido ao revelar processos físico-químicos globais dos ecossistemas, mas as linhas de fluxo, as quantidades e trocas energéticas, os equilíbrios e a percepção de qualidade de vida são apreendidas em função de especificidades técnico e histórico particulares, paisagisticamente circunscritas.

Os conceitos e jurisprudência dos processos que tratam de paisagem e dano ambiental e dano moral ambiental sustentam este argumento, contudo?

Em relação à paisagem, se tentamos assimilar o significado de meio ambiente através do uso do termo na jurisprudência do Tribunal de Justiça de Minas Gerais, a pesquisa nos mostra que a paisagem participa do meio ambiente enquanto conteúdo material e estético. Sem revelar exatamente uma naturalização do meio ambiente, a paisagem indica, entretanto, uma porção da superfície terrestre e uma fisionomia, 
uma estética visual, as quais, objetivamente consideradas, importa proteger ambientalmente.

Por outro lado, os julgamentos parecem assumir a existência objetiva da paisagem, essencialmente seu cunho material, sendo suas características adotadas como subsistentes em si mesmo e, em consequência, também o meio ambiente. De fato, no universo dos processos pesquisados, não há reflexões específicas acerca do caráter relativo e subjetivo da configuração da paisagem, principalmente quanto à valorização estética.

Em outras palavras meio ambiente apreendido enquanto paisagem é um espaço concreto tomado como relevante para a preservação e proteção dos sistemas naturais; é também uma ordem estética, visual deste espaço concreto.

Em relação ao conceito de dano ambiental e dano moral ambiental, temos que os conceitos são abertos para interpretações que considerem a lesão ambiental causada para além de seu caráter natural, pois permite o vínculo do ecológico com valores sociais.

De fato, o meio ambiente incorpora neste caso tanto a natureza (dano ecológico puro, segundo classificação de Leite e Ayala (2015)) quanto os valores humanos vinculados à natureza. São afetados assim, em consonância com a lesão ecológica pura, valores culturais ligados aos componentes ambientais, como o equilíbrio ecológico e a qualidade de vida.

A jurisprudência do tribunal mineiro mostra que esta ligação é considerada na decisão de mérito dos juízes, porém, os valores associados aos danos ambientais tendem a restringir-se, em geral, ao equilíbrio ecológico, aos valores ecológicos da comunidade, ou ao direito difuso ao meio ambiente, enfim. Isto é, tem-se como valores sociais reconhecidos, a serem tutelados pelo Direito, a manutenção dos equilíbrios naturais, das funções ecológicas que as espécies animais e vegetais mantêm com o meio, e dos processos ecológicos essenciais cuja lesão causem dor, sofrimento e angústia na comunidade.

Por outro lado, os danos ambientais são, na sua maioria, vinculados a prejuízos, degradações nas condições da natureza, de seus elementos naturais. Realmente, no elenco de danos ambientais listados de acordo com a jurisprudência do Tribunal de Minas Gerais, figura a matança de animais e o aprisionamento de pássaros silvestres, o desmatamento ou corte da vegetação nativa. Outros danos derivados de barulho excessivo, irregularidade em loteamento, extração mineral, 
atividade de empresa transportadora reportam-se, da mesma forma, a prejuízos causados à natureza, como o rebaixamento e poluição do lençol freático, erosão do solo e assoreamento de rios, supressão da vegetação, poluição atmosférica, modificação da morfologia (paisagem) da área e danos à fauna e a flora.

Ou seja, há o reconhecimento de que o meio ambiente constitui-se também de valores sociais; estes, contudo são descritos em termos naturais. Configura-se uma limitação no sentido de que os laços valorativos com meio ambiente, assim considerados, apreendem meio ambiente na sua unidade natural, ecológica, representação simétrica local de processos e modelos ecológicos reprodutíveis em diversas escalas. Todos necessários à proteção do meio ambiente, mas resta ausente perspectiva que os coloque em termos paisagísticos locais, de apropriações comunitárias em diversos níveis técnicos e simbólicos.

A ideia de meio ambiente apreendido enquanto natureza torna-se mais próxima nas discussões em torno do Paço Municipal de Poços de Caldas. Com efeito, não é outro o entendimento de fundo posto tanto na petição inicial do Ministério Público quanto nas decisões judiciais finais. No caso, a sub-bacia foi narrada, descrita pelos processos hidrogeológicos locais e, assim, enquadrada na legislação. É nesse sentido também que o estudo da Fundação Gorceix e os argumentos das diversas associações e organizações da sociedade civil são destacados.

Se, de fato, a sub-bacia do ribeirão das Vargens contêm os processos hidrogeológicos considerados, como descrevê-la em termos da apropriação humana realizada? Os fundamentos naturais pelos quais são descritos a sub-bacia devem ser redimensionados na medida em que a ocupação urbana, as atividades mineradoras e a produção agropecuária ali existentes amalgamam ao meio os componentes técnicos e simbólicos.

Em suma, o que o conjunto do material pesquisado mostra, enfim, é a repetição do paradigma dicotômico homem-natureza tanto nos princípios e conceitos quanto na jurisprudência trabalhada. Definidos dentro de concepções ecológicas do meio ambiente, os processos naturais, os equilíbrios e interdependências biocenóticas, os movimentos físicos e químicos entre o mundo físico e a fauna e flora dão o contorno do meio ambiente como entendido pelo Direito Ambiental. No conjunto da doutrina e jurisprudência descrita, enfim, o meio ambiente confunde-se com os ecossistemas, com a natureza enquanto algo concreto, traduzida no seu 
caráter material, comandada por processos físicos e bioquímicos, cuja fisionomia e visual por vezes, segundo necessidades de ordem natural ou estética, convêm preservar.

Poder-se-ia argumentar que é realmente do meio ambiente natural de que se trata e que a participação humana estaria expressa no meio ambiente artificial, cultural ou do trabalho, algo que desconsideraríamos. Ademais, estaríamos supondo ou privilegiando apenas a interpretação dogmática gramatical e não levaríamos na devida conta uma interpretação sistemática entre as normas, o que talvez trouxesse maior humanização do meio ambiente e seus elementos (pensando no desenvolvimento do socioambientalismo no Brasil, como defende Santilli (2005)).

No primeiro caso, porém, teríamos um Direito Ecológico e não um Direito Ambiental; quer dizer, os princípios e conceitos do Direito Ambiental se colocam para todo o meio ambiente: seja ele meio ambiente natural, artificial, cultural ou do trabalho, são todos regidos pelos mesmos princípios do Direito Ambiental.

Cabe mais razão no segundo caso porquanto uma interpretação sistemática realmente levaria a conceituações menos naturalizantes. Todavia, nem a pesquisa na doutrina brasileira nem na jurisprudência mineira mostra esta interpretação sistemática das normas.

A propósito, no âmbito geral da legislação ambiental, não é novo desconsiderar a dimensão social na normatização e aplicação das exigências ambientais. De fato, Ariella Kreitlon Carolino (2016), em recente estudo sobre a inclusão do social na avaliação de impacto ambiental, conclui justamente pela fragilidade e subordinação do social no interior dos estudos de impacto de grandes obras de infraestrutura sobre o meio ambiente.

A falta de precisão conceitual de meio ambiente, a exclusão de questões de equidade e justiça social nas lutas históricas dos movimentos ambientalistas (geralmente conservacionistas) em defesa do meio ambiente, a visão tecnocrática e reducionista que predominou na política ambiental brasileira são algumas das razões apontadas pela autora para explicar tal fragilidade e subordinação encontradas (CAROLINO, 2016).

Mesmo em face dos avanços promovidos com a Constituição de 1988, quando o socioambientalismo emergente ganhou força normativa e institucional, predominou ainda visões restritivas acerca do meio ambiente: 
Destarte, ainda que tenha angariado consideráveis adeptos e conquistado influência na virada para os anos 90 (tendo a Constituição de 1988 como um dos seus principais trunfos), não parece claro que o setor representativo do socioambientalismo tenha logrado estabelecer o domínio de seu viés holístico na conformação do principal arcabouço jurídico da regulação ambiental brasileira. (CAROLINO, 2016, p. 62).

Se falta a devida consideração do componente social nos estudos de impacto ambiental, o mesmo pode ser dito em relação aos conceitos e princípios de Direito Ambiental. Quer dizer, o meio ambiente visto pela definição dos seus elementos pouco ou nada incorpora da dimensão humana e social, ficando restrita ou limitada ao seu substrato ecológico e natural.

Enquanto pela teoria do ecúmeno o homem, individual ou socialmente, se relaciona com os espaços onde habita, produz e vive suas relações sociais sob uma comunhão ecológica mas não menos simbólica, ética, histórica e técnica, no Direito Ambiental a sociedade se relaciona com o meio ambiente, este bem jurídico que se quer que integre o natural e artificial, predominantemente na sua dimensão natural e material.

\subsection{MEIO AMBIENTE ENQUANTO TOTALIDADE NATURAL.}

Em outra perspectiva, o meio ambiente visto enquanto natureza dá uniformidade ao discurso jurídico na medida em que esse meio ambiente é capturado na totalidade natural terrestre que coforma. É o meio ambiente entendido na unidade da "Mãe Terra". Desse modo, a universalidade dos processos naturais, a igualdade das leis bio-físio-químicas gerais que regem o funcionamento dos ecossistemas desenham uma homogeneidade ambiental passível de apreensão pelo Direito.

Realmente, analisando os princípios e conceitos, suas definições refletem modelos teóricos de validade universal em detrimento das apreensões particulares que assumem.

Priorizam-se os fenômenos ambientais mais na sua dimensão de totalidades naturais e menos nas particularidades paisagísticas que assumem, contribuindo, assim, para uma contingência naturalizante do meio ambiente e pondo em segundo plano a especificidade simbólica, técnica, histórica que carregam.

A jurisprudência sobre dano ambiental no Tribunal de Justiça de Minas Gerais é exemplificativo, nesse sentido, como no caso da condenação pela manutenção de 
pássaros da fauna silvestre em cativeiro: o dano está vinculado ao equilíbrio e funções ecológicas gerais que os animais desempenham, não alcançando os danos morais ambientais a esfera de valores comunitários manifestados localmente, senão ao direito difuso ao meio ambiente equilibrado.

Nos casos de poluição dos recursos hídricos pela instalação de loteamentos irregulares ou pela limpeza de caminhões, nos processos que cuidam de intervenções em áreas de preservação permanente, também os danos ambientais são associados a estruturas e processos naturais gerais, uniformes, reprodutíveis em outras escalas; as considerações do mérito da lide pouco descendo para escalas de vivência particulares de grupos sociais.

A narrativa desenvolvida é de espaços, de uma realidade geográfica onde o meio ambiente é padrão, uniforme, onde a naturalização dos fenômenos torna possível a totalização dos processos ambientais em detrimento de sua manifestação numa escala paisagística local ou reginonal. O meio ambiente torna-se restrito porque desconsidera a esfera de integração social - e homogêneo, uma vez que isônomico em qualquer contexto paisagístico.

A propósito, retomando os estudos interdisciplinares entre a Geografia e o Direito, Bartel e Graham (2013) insistem precisamente nesta universalidade do Direito e na superposição das normas sobre a heterogeneidade espacial dos lugares. O que as pesquisas tem demostrado, dizem os autores, é um Direito "universal e universalizante", homogêneo, no estilo "'one-size-fits-all' law"21: "Ele [Direito] tende a passar por cima da heterogeneidade espacial e da natureza do fundamento geográfico do seu próprio processo" (BARTEL; GRAHAM, 2013, p. 340).

Essa restrição e homogeneidade na descrição do meio ambiente é objeto inclusive de crítica que Patrícia Bressan da Silva dirige ao Direito Ambiental. A autora considera-o como um "novo discurso ideologizante" nascido a serviço da cultura econômica globalmente voraz e protecionista: "o Direito do Ambiente é sistemática jurídica fabricada para regular a expectativa de se criar um eixo comum de valores internacionais em torno de práticas interessada a respeito do uso sustentado dos recursos ecológicos". Desse modo, a literatura de Direito Ambiental é "política e conjuntural" e a política socioambiental ao agregar valores de "ambiente exigido

21 "Um tamanho cabe em tudo" em tradução livre. 
saudável ou ecologicamente equilibrado, se pousa como conceitos que apenas viabilizam um fim determinado" (SILVA, 2004, p. 269).

De acordo com Afrânio Nardy (2003), por outro lado, a uniformização do meio ambiente pode ser encarada pela perspectiva de topos e chôra. Assevera o autor que existe uma visão do espaço enquanto topos, simples continente, palco "dos processos naturais, dos dramas humanos e das tramas sociais", quando, na verdade, o espaço é constitutivo da vivência e geograficidade dos homens. Nesse sentido, o meio ambiente está "impregnado de valores variados" que dialogam com quadros experienciais específicos, "compostos pelas formas peculiares de interação desses grupos com outros elementos dos sistemas ambientais" (NARDY, 2003, p. 172).

Encarado no contexto do Direito, desse modo, o espaço deve traduzir a alteridade do chôra dos grupos sociais "como parte inseparável do pleno exercício por esses grupos de seus direitos culturais" (NARDY, 2003, p. 158). Afirma:

De fato, assumindo o espaço como nota intrínseca da existência do homem, pode-se afirmar que um dos papeis fundamentais do Direito Ambiental consiste precisamente em assegurar que as práticas sociais se revistam da devida preocupação com a proteção da geograficidade específica dos grupos humanos (NARDY, 2003, p. 171).

Analisando o princípio da precaução no Direito Ambiental, Nardy conclui:

O sentido do dever de cautela preconizado pelo princípio da precaução não pode ser decotado em um discurso jurídico que tenha como pano de fundo uma concepção reificada do espaço, pela qual este é pressuposto como topos (...). Somente por intermédio da recuperação da geograficidade dos grupos sociais se pode alcançar simultaneamnte a substantivação do dever de cautela subjacente ao princípio da precaução e a significação dos riscos socioambientais que por sua aplicação se pretende extirpar (NARDY, 2003, p. 196).

Os princípios e conceitos de Direito Ambiental, com efeito, pela necessidade de isonima territoral requerida pelos sistemas jurídicos nacionais, suprimem as diversidades paisagísiticas que porventura ocorram sobre 0 território e as diversidades de interações técnicas e simbólicas com os sistemas ecológicos. $\mathrm{Na}$ disciplina ambiental, a isonomia do meio ambiente para realidades paisagísticas diversas é conseguida pela sua restrição à totalidade da natureza e seus processos ecológicos universais.

A análise da jurisprudência não diverge muito desta perspectiva: no conjunto dos processos, o meio ambiente é menos o universo simbólico e vivencial dos 
grupos envolvidos e mais seu substrato ecológico. A relação da comunidade com o meio ambiente é substantivada, principalmente, pelo conteúdo natural, porquanto é a ele que se reportam os princípios e conceitos que norteiam o Direito Ambiental.

A menção à dor, sofrimento e angústia experimentados pelos indivíduos ou grupos podem ser consideradas incipientes na inclusão da dimensão humana no meio ambiente, uma vez que eles não se desenvolvem no sentido de chôra. Isto é, apesar do aspecto social fazer-se presente no entendimento de dano ambiental, falta-lhes desenvolverem-se como conteúdo histórico, técnico, simbólico particulares. Realmente, observando a jurisprudência trabalhada, o elemento social é considerado de maneira abstrata e uniforme, onde população ou comunidade comungam de valores comuns em relação ao meio ambiente mas não forjam suas próprias geograficidades.

Deve-se ser menos enfático com relação à jurisprudência de paisagem: a ideia de paisagem como um aspecto material do meio ambiente trabalhado ou valorizado estéticamente pelo homem traz de forma tácita o empreendimento técnico, cultural e histórico de sua formação. Mas essa relação é antes presumida do que demostrada, pelo menos nos processos analisados. A paisagem da Praça Monsenhor Pedro Cintra, a paisagem urbana de Belo Horizonte, a paisagem da Serra dos Cristais foram reconhecidos como objeto de tutela ambiental sem se estabelecer os nexos que se formam com a comunidade em questão, ou pelo menos a decisão de mérito assim não se baseou.

\subsection{FUNDAMENTOS DOS FATOS: NARRATIVA JURÍDICO-GEOGRÁFICA DO MUNDO}

Na medida em que os princípios e conceitos ambientais dão os contornos do meio ambiente, eles forjam concomitantemente uma narrativa do mundo - narrativa geográfica - do que seria meio ambiente e da sua relação com o homem.

Essa construção discursiva da realidade geográfica operada pelo Direito já era sublinhada, inclusive, nos estudos de Geografia do Direito desenvolvidos por Ronen Shamir (2001), Nicholas Blomley (2001), David Delaney (2001) Sarah Whatmore (2003). Cria-se uma narrativa jurídica sob o meio ambiente, dos seus elementos componentes e como deveria ser a relação da sociedade com esse meio: 
o que é permitido ou proibido fazer; as áreas que devem ser preservadas; as qualificações que se devem ser imputadas.

O que se observa no conjunto de dados analisados é um meio ambiente descrito em termos naturais que trabalha no sentido de construção de uma realidade regida somente por processos mecânicos e biológicos; olvida-se a variedade de processos sociais na conformação de diferentes realidades ambientais onde 0 equilíbrio ecológico, os processos ecológicos essenciais, a biodiversidade constituem-se na emergência trajetiva com as sociedades, as técnicas, com seus valores culturais e simbólicos.

Ao configurar este universo semântico, os princípios e conceitos de Direito Ambiental traçam os limites da descrição jurídica da realidade geográfica. É, em outras palavras, a acomodação da realidade geográfica do mundo à dimensão dos significados principiológicos e conceituais adotados no Direito Ambiental. Nesse sentido, de fato, já se observou que "a linguagem do Direito nega a linguagem diária da experiência social substituindo-a pela linguagem formal da lei" (FORD, 2001, p. 111) onde "o sistema de representação jurídica assim criado permite deslocar o debate do mundo complexo 'real' a um mundo abstrato 'jurídico' onde o jogo simbólico tem lugar (PERRET, 1994, 522).

Configura-se um universo semântico de operação da hermenêutica e da aplicação do Direito e, no caso do Direito Ambiental, uma interpretação predominantemente naturalizante do mundo.

Com efeito, os princípios conformam um entendimento sobre o meio ambiente que atua na correta "compreensão e inteligência" da norma (MELLO, 1980 apud MILARÉ, 2013).

Os conceitos operam na mesma direção de produzir uma esfera de significação do meio ambiente, refletindo assim nas formas de interpretação e na aplicação do Direito. Seja o núcleo rígido de significação dos conceitos, seja nas suas ideias conexas, nas suas indeterminações passíveis de exegética hermenêutica (MAXIMILIANO, 2010), idealiza-se um campo de compreensão, um limite conotativo e de adequação do caso concreto à norma jurídica.

Assim, os processos de interpretação das normas, de preenchimento de lacunas ou a subsunção de casos concretos à lei acabam orbitando no entorno deste universo semântico restrito do meio ambiente, construído na confluência da doutrina e da jurisprudência (e na verdade também da legislação). 
É no sentido de compor o espírito da norma, de preencher-lhe as lacunas ou de categorizar os fatos aos fundamentos jurídicos que os princípios e conceitos de Direito Ambiental engendram um universo de entendimento geográfico do mundo, do meio ambiente especificamente, de interpretação e operação do Direito. É sob o intervalo semântico dos princípios, concepções legais e doutrinárias e do conjunto da jurisrudência que o jurista intenta interpretar a lei e fazer a subsunção do caso geográfico concreto à geografia da norma legal abstrata para que, assim, o fato narrado tenha validade. É um verdadeira operação de qualificação jurídica onde o fato é considerado sob certa categoria legal (TROPER, 2008).

Por esse processo, a indicação dos fatos (geográficos) ficam adstritos às fundamentações jurídicas das categorias do meio ambiente (natural), devida e geograficamente caracterizados no Direito Ambiental.

Com efeito, questões como desequilíbrios ecológicos do meio ambiente, alterações nos processos ecológicos essenciais danos ambientais não são compostas em termos de experiência paisagística do grupo, mas nas categorias jurídicas predominantemente ecológicas.

Nessa direção, o Direito Ambiental contem as possibilidades segundo as quais a composição de interesses pode ser equacionada. Conforme afirma Enrique Leff:

As próprias formas do ordenamento jurídico e os tempos dos procedimentos legais são um obstáculo à tradução do discurso à eficácia de um instrumento jurídico que na prática viabilize a defesa legal dos direitos ambientais e coletivos (LEFF, 2011, p. 353).

Afrânio Nardy, por outro lado, sustenta:

Torna-se muito delicada a tarefa de elaborar e implementar políticas de proteção do meio ambiente, pois é possível afirmar que, quando a geograficidade de determinado grupo social é suprimida ou deixa de ser considerada em qualquer desses processos decisórios ocorrerá, consequentemente, uma espécie de 'dano socioambiental', mesmo que estes não se revele perceptível para outros grupos, dotados de diferentes padrões de experiência espacial [pois] a afirmação do Direito fundamental ao meio ambiente ecologicamente equilibrado exige, de modo inarredável, tanto o explícito reconhecimento das formas particulares de interação entre o homem e seu meio quanto o respeito às paisagens culturais por seu intermédio constituídas (...) (NARDY, 2003, p. 172-173).

Afinal, é uma geografia que se impõe: são formas de entender o meio ambiente, de qualificar as paisagens, de tornar proibidos ou permitidos determinados 
comportamentos que se sobrepõem sobre outros modos de conhecer, ser e agir no espaço.

"O Direito está preferencialmente conectado, e portanto perpetua, certos valores a outros", nos dizem Bartel e Graham (2013. p. 344). Para os autores, o Direito faz o mundo à sua própria imagem, "nem sempre conscientemente e frequentemente com efeitos desconhecidos", onde alguns valores como a certeza e a universalidade da lei devem manter-se proeminentes de forma a garantir a totalidade da lei. Contudo, esta homogenização da lei pode gerar injustiças, ponderam:

Esta generalização e normalização das forças do Direito pode render injustiças, se através da aplicação das categorizações de diferença sobre as quais práticas exclusivas são exercidas, tais como othering e limites, ou ignorando diferenças (por exemplo a heterogeneidade dos ambientes e das pessoas) e promovendo (aparentemente) tratamento justo mas na realidade causando egregious injustos efeitos (BARTEL; GRAHAM, 2013, p. 344).

Veja o caso da paisagem e dano ambiental: aquela é subsumida nos processos enquanto dimensão visual, fisionômica e estética do meio ambiente. As lides não são compostas tendo a paisagem como mediadora do espaço existencial do homem. Os processos mostram que são descaracterizações nas formas ou no visual aparente do meio ambiente que são equacionados enquanto paisagem; já lesões de ordem valorativa ou simbólica - restritos, como argumentou-se, a fundamentos naturais - são categorizados como danos morais ambientais.

Quando a querela jurídica envolvia o Sítio do Gogô, por exemplo, mesmo reconhecida como paisagem cultural, a construção da escola foi proibida face "à descaracterização da topografia e do aspecto visual natural da área".

Nos fundamentos de fato da ação promovida pelo Ministério Público a respeito do Paço Municipal de Poços de Caldas, os conceitos e princípios ambientais (naturais) foram as categorias sob as quais a sub-bacia do ribeirão das Vargens foi descrita. No entanto, o Paço iria instalar-se não sobre um espaço puramente natural que passivamente receberia as obras do empreendimento. Marcas da ocupação urbano, industrial e agrária é que caracterizam a região. Os limites ecológicos dos conceitos e princípios ambientais deixaram pouco espaço para considerações de ordem paisagística local. 


\subsection{COMPOSIÇÃO DA MEDIANCE E DA PAISAGEM}

Considerando os conceitos, princípios e a jurisprudência trabalhada, como o Direito Ambiental participa da composição da mediance e da paisagem? Qual o sentido introduzido pelo Direito Ambiental nas relações da sociedade com o meio que ocupa e produz e qual a concretude assumida pela disciplina normativa ambiental?

Ao menos subjetivamente, nos arranjos paisagísticos em cada caso, foram incorporados valores provenientes do Direito Ambiental nos sentidos desenvolvidos na relação com o meio. E, se assumidas as análises anteriores, foram introduzidas apreensões de ordem naturalizante e uniforme do meio ambiente considerado.

Destarte, um valor ecossimbólico jurídico está a balizar (ou coargir, conforme as decisões judiciais) a relação com a fauna silvestre, o uso de áreas verdes, a utilização dos recursos hídricos e do relevo e, no sentido da jurisprudência, a apropriação estética do meio ambiente.

Assim, a vivência social subjetiva com os espaços representados nos processos está embebida num "invólucro jurídico" forjado no seio do Direito Ambiental que norteia a trajeção em função dos equilíbrios ecológicos e processos naturais ecossistêmicos como forma de manutenção da qualidade de vida.

Em conjunto, os sujeitos passam a experienciar as paisagens como ambientes de proteção ecológica, sendo os elementos desta paisagem (os pássaros, os rios e lagos, as formações florestais, as formas do relevo, o ambiente atmosférico e sonórico), em grande medida, assimilados como componentes simbólicos dos valores jurídico-ambientais que se quer tutelar (direito ao meio ambiente equilibrado e sadio).

Talvez os processos sejam um outro momento na conformação de uma temisfera ambiental com relação aos locais de litígio, somando-se a preocupações preexistentes mais do que inovando na percepção ambiental, como no caso envolvendo a construção do Paço Municipal de Poços de Caldas. Um valor ambiental (natural) já vinha sendo forjado desde o Plano Diretor Municipal de 1992, quando às atividade econômicas e à ocupação urbana são acrescentadas preocupações com os cursos d'água e a cobertura vegetal.

Em todo caso, modelada legalmente nas narrativas de fato e na decisão de mérito, os processos também fizeram ressaltar e consubstanciaram uma temisfera 
em sentido ecológico (hidrológico e hidrogeológico, especificamente) em relação à paisagem da sub-bacia do ribeirão das Vargens.

Nesta direção, o empreendimento de construção do Paço Municipal ficou agravado, porquanto incondizente com a esfera de valores jurídicos/legais assimilados a área. Uma mediance ecológica foi a narrativa das relações com o local, e sua defesa e proteção os objetivos que fundamentaram os pedidos de licenciamento ambiental.

Mas qual a correspondência material de tal mediance na paisagem? Como, no contexto do Direito Ambiental, a maneira naturalizante de apreender, apropriar-se e vivenciar o meio ambiente desdobra-se materialmente na paisagem?

$\mathrm{Na}$ sub-bacia do ribeirão das Vargens, o processo judicial não teve como corolário intervenções antrópicas que conformassem transformações no ambiente de forma a caracterizar as marcas humanas na paisagem. Do contrário, embora se decidisse, ao final, pela não obrigatoriedade do licenciamento ambiental e da regularidade das ações praticadas pela prefeitura municipal, a judicialização do processo desestimulou qualquer intenvenção do poder público no local (imagens 1; $2 ; 3 ; 4 ; 5)$.

Figura 1 - Imagem de satélite de parte da sub-bacia do ribeirão das Vargens

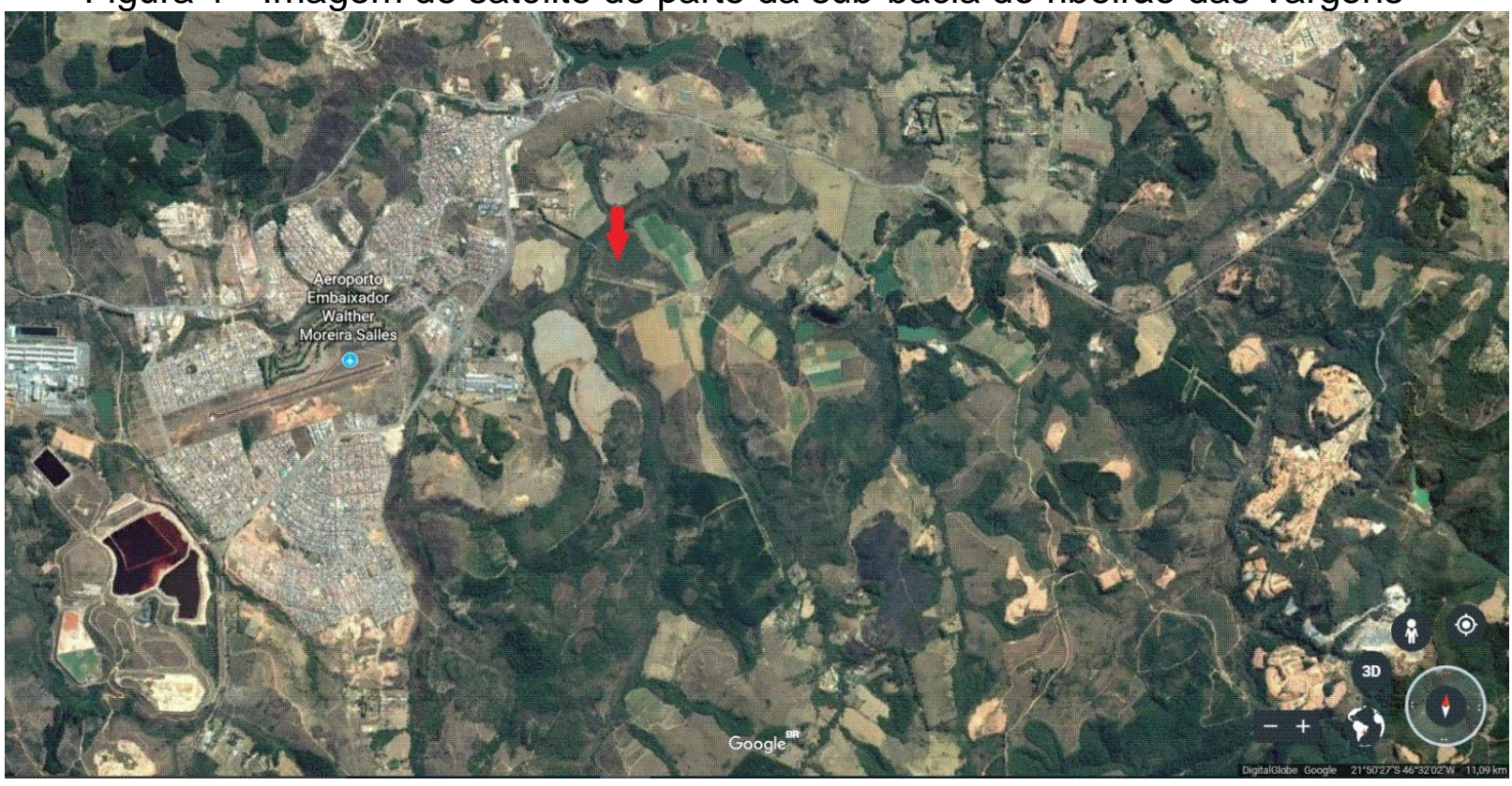

A seta vermelha indica o local onde seria construído o Paço Municipal.

Fonte: GoogleEarth, 2017. 
Figura 2 - Área onde seria implantado o Paço Municipal

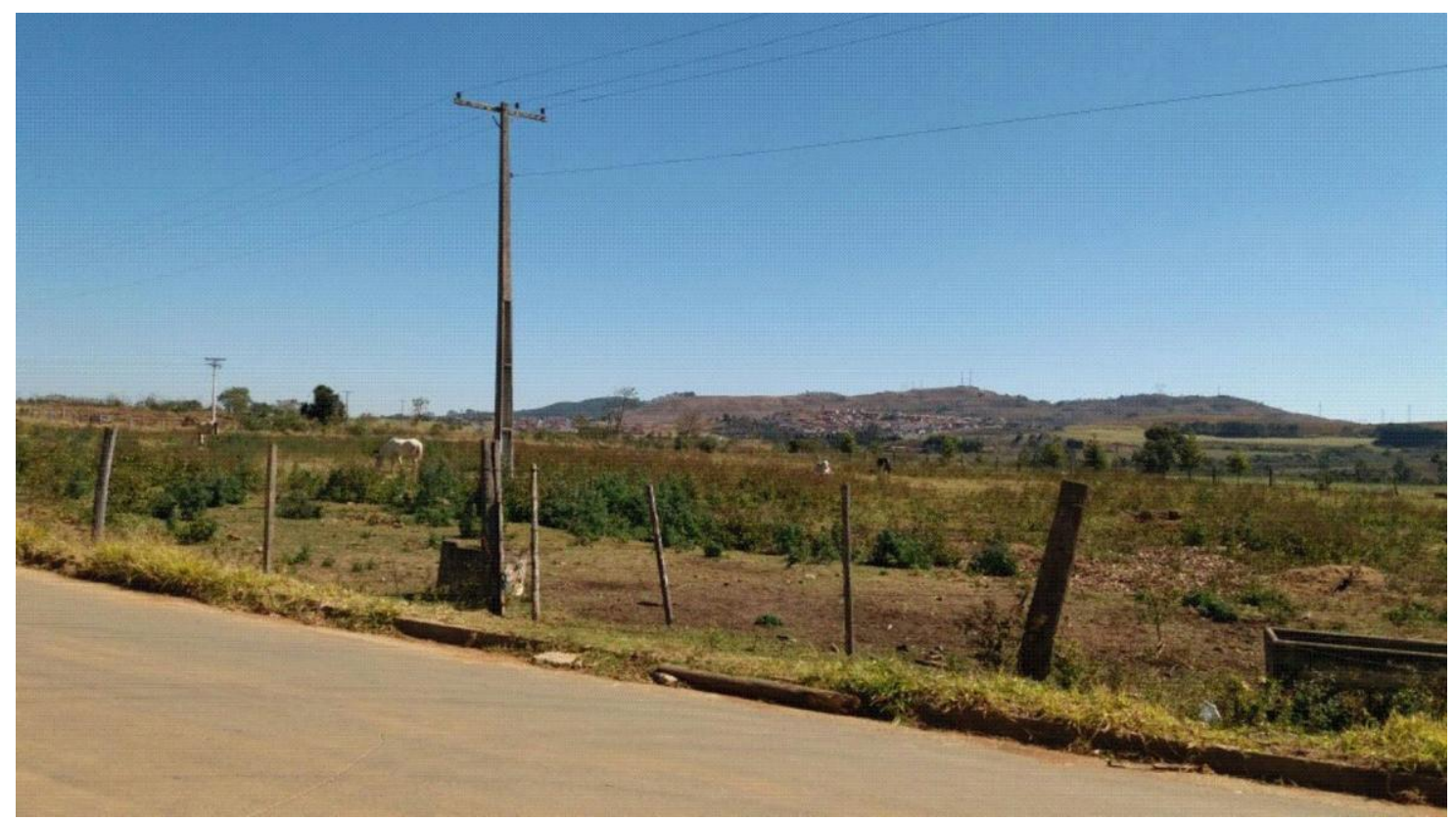

Fonte: Fotografia tirada pelo autor, 2017.

Figura 3 - Silvicultura e plantação de aveia

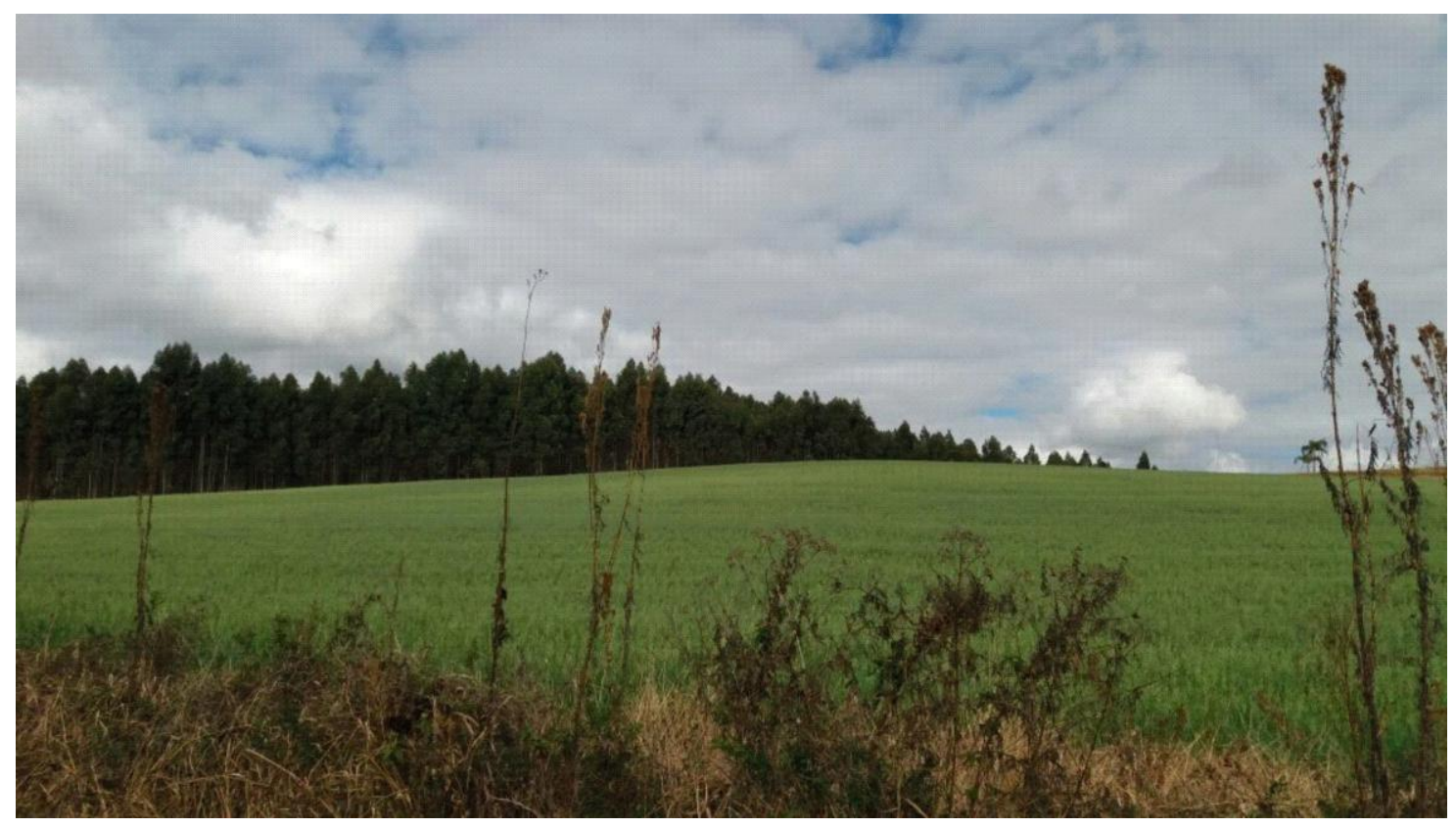

A foto mostra, em primeiro plano, plantação de aveia e, em segundo plano, plantação de eucalipto. Fonte: Fotografia tirada pelo autor, 2017. 
Figura 4 - Vista parcial da sub-bacia do ribeirão das Vargens

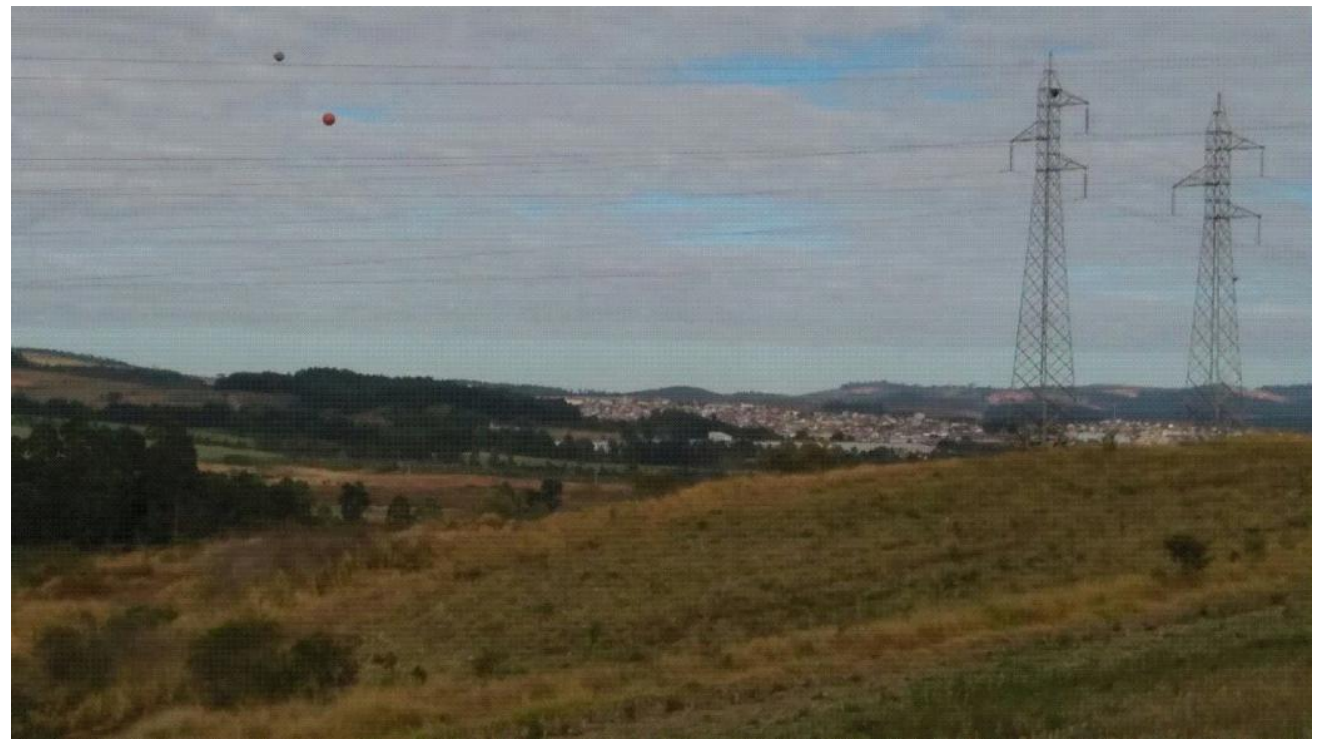

No primeiro plano da foto, pasto sujo; no segundo plano, área urbana ocupando a jusante da subbacia do ribeirão das Vargens.

Fonte: Fotografia tirada pelo autor, 2017.

Figura 5 - Mineração e aterro

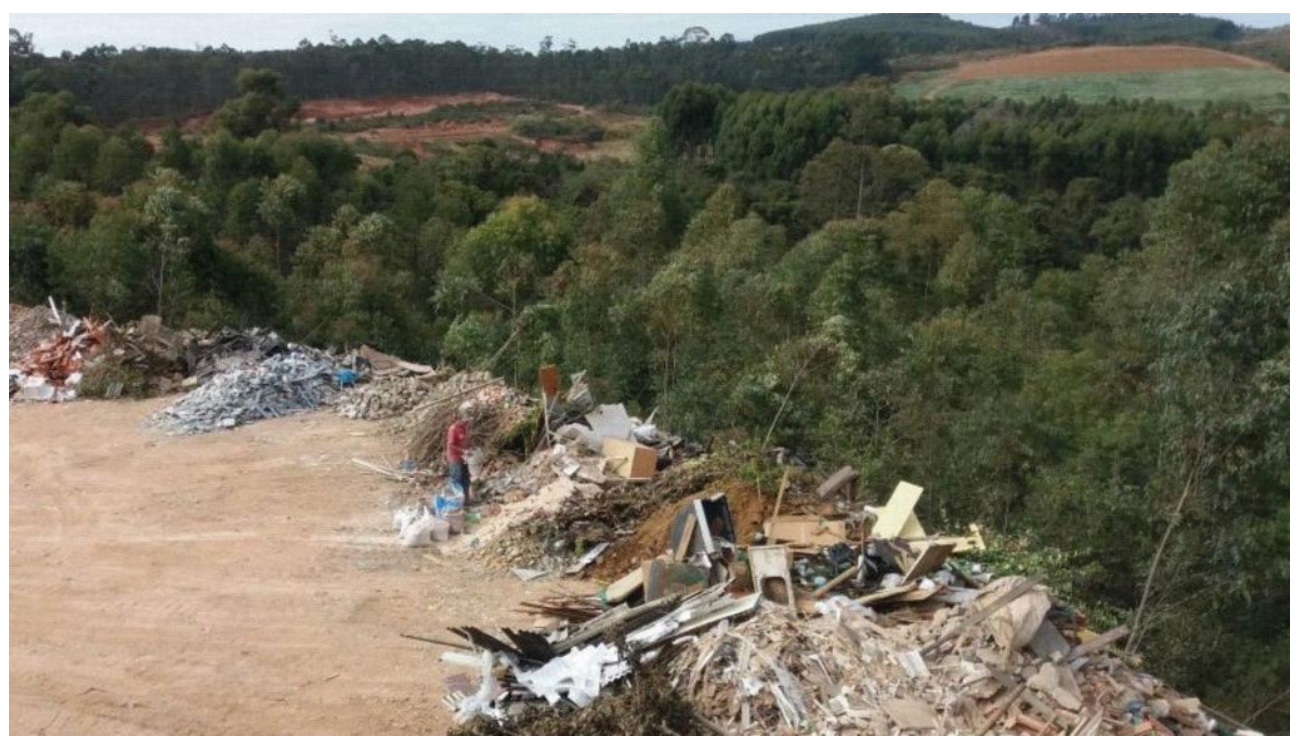

Área de aterro de entulhos com solo exposto em primeiro plano. Ao fundo, no segundo plano, lavra de mineração.

Fonte: Fotografia tirada pelo autor, 2017.

Nesse sentido, a ação judicial promovida pelo Ministério Público contribuiu, mais do que decidiu ou determinou, para manutenção e permanência das formas existentes, apesar de reforçar o conteúdo simbólico ecológico que carregam (paisagem como matriz). Com efeito, a proeminência de uma mediance ecológica 
contruída juridicamente levou à continuidade do quadro paisagístico existente frente aos potenciais danos causados pela instalação do Paço Municipal.

Interessante papel desempenhado pelo processo a respeito do Paço sobre a paisagem local. Assentado sobre as características naturais da sub-bacia, a decisão judicial indeferiu os pedidos do Ministério Público assegurando as legalidades e correções das ações do poder público municipal. Apesar disso, o processo serviu como catalizador da mediance ambiental/natural que recobre a área e para fixidez temporária da materialidade paisagística existente, embora os valores de direito ambiental the dêem novas qualidades e permeiem seus usos.

O mesmo acontece a respeito da proibição de instalação de antenas de rádio base em Belo Horizonte, da construção de concha acústica na Praça Pedro Cintra em Borda da Mata ou de escola no Sítio do Gôgo em Mariana: nestes casos, o Direito, na figura dos processos, agiu no sentido de coibir ou mesmo barrar transformações concretas na paisagem ao mesmo tempo que garantiu a permanência desta mesma paisagem.

A propósito da manutenção da paisagem, os estudos sobre a influência das leis na formação da paisagem de Poços de Caldas, realizado durante o mestrado, revelou um conjunto de normas que, igualmente, sem desdobrarem-se em intervenções antrópicas diretas, trabalharam para a manutenção do quadro paisagístico presente no centro da cidade.

Realmente, um conjunto de leis de proteção ao patrimônio histórico, cultural e estético coibe transformações na paisagem urbana do centro municipal frente às descaracterizações arquitetônicas e verticalizações observadas no entorno da área central, a exemplo das leis de proteção patrimonial e das leis que proibem a verticalização do centro municipal (SOUZA, 2012). 


\section{CONCLUSÕES}

A análise do Direito Ambiental empreendida neste trabalho teve como objeto principal a construção doutrinária dos conceitos e princípios ambientais e os processos existentes no Tribunal de Justiça de Minas Gerais relativos ao uso dos termos paisagem e dano ambiental. Trouxemos para análise mais próxima, também, o processo envolvendo a construção do Paço Municipal de Poços de Caldas.

Os dados permitiram sublinhar os entendimentos e interpretações jurídicas sobre meio ambiente e os elementos a ele pertencentes (ecossistema, paisagem, equilíbrio ecológico, processos ecológicos essenciais, etc.), de forma a caracterizar os significados comuns subjacentes a eles.

Os resultados são restritos, porém, ao universo do material pesquisado, sendo que generalizações devem ser tomadas com constantes ressalvas. A própria diferença na distribuição quantitativa do uso do termo paisagem pelos Tribunais de Justiça do país aponta e sugere desigualdades na aplicação das técnicas, instrumentos e princípios de Direito Ambiental.

Ademais, a concentração da pesquisa nas faculdades das regiões Sul e Sudeste, em relação aos doutrinadores mais citados, e na jurisprudência do Tribunal de Justiça de Minas Gerais contribuem para limitações de análises generalizantes.

Críticas também poderiam ser estendidas para os métodos de pesquisa dos processos: primeiro porque a análise da fase final, a decisão de mérito das ações pela Corte, deixou de fora o exame da petição inicial, amputando as interpretações de um momento importante de narrativa dos "fatos ambientais", de subsunção do caso concreto às hipóteses abstratas da lei e de aplicação dos princípios e instrumentos de Direito Ambiental. Ademais, porque os termos pesquisados, escolhidos pela abertura semântica extensiva que possibilitam do conceito de meio ambiente, não dizem de todo o Direito Ambiental e talvez nem sejam os conceitos mais importantes dentro do sistema jurídico considerado.

De qualquer forma, e atentando para generalizações falaciosas, o conjunto de dados analisados, quando tomados historicamente, mostrou certa continuidade com o paradigma dicotômico da ciência moderna tendo em vista que identifica o meio ambiente com a natureza propriamente dita, divorciada e diferente da esfera humana e social. Isto a despeito das leituras extensivas da doutrina do conceito legal de meio 
ambiente. Reproduz-se no Direito Ambiental a separação entre a esfera do mundo natural e a esfera humana.

Realmente, permanece na regulamentação da relação do homem com o meio ambiente descrições e interpretações dos fatos ambientais segundo relações biocenóticas, as funções desempenhadas pelos organismos e o meio físico nos ecossistemas ou dos movimentos de matéria e energia que se operam entre a biocenose e o biótopo. Os fatos ambientais são assim entendidos tendo como valores precípuos a proteção que se quer do quadro natural.

$\mathrm{Na}$ compreensão das relações estabelecidas com o meio ambiente, o Direito Ambiental sofre, então, considerável influência das Ciências Biológicas e Ecológicas na definição de um dos polos que se quer regulamentar na relação - o meio ambiente. O Direito Ambiental adota os conceitos da biologia e da ecologia como um dos seus fundamentos, sem realizar adaptações ou interpretações extensivas que redimensionem as definições bioecológicas em razão da sua existência em simbiose com a presença humana.

Historicamente ainda, é possível identificar a permanência de uma visão econômica em relação ao meio ambiente na medida em que este se torna traduzível e mensurável nas suas diversas quantificações, isto é, nos índices de poluição, nas taxas de desmatamento, nas concentrações químicas, nos volumes de biomassa, etc. É a corrente instrumental, como denominam Cunha e Coelho (2012), que se revela na disciplina normativa ambiental.

Se é a relação do homem com o meio ambiente que o Direito Ambiental almeja regulamentar, visando a qualidade de vida, o equilíbrio ecológico e a sustentabilidade para as futuras gerações, o meio ambiente, dessa forma, já é algo dado a priori, pronto, mensurável, pois ele não passa da identificação, nos casos concretos, do meio ambiente jurídico previamente definido.

Em analogia com a ideia de espaço que predominou e ainda predomina como sendo simples palco, objeto passivo sobre o qual age a força humana, também o meio ambiente no Direito Ambiental é a natureza passiva sobre a qual a ação antrópica se dá, sem alteridade senão aquela advinda dos próprios arranjos ecossistêmicos.

Não se quer dizer que o conhecimento do substrato ecológico seja desnecessário ou inválido para compreensão e regulamentação da relação do homem com o meio ambiente, mas compreender que o meio onde o homem vive, 
habita e produz é um meio social; ou seja, entender que o substrato terrestre apresenta-se antes socialmente, na medida da interiorização simbólica e do desenvolvimento técnico a ele incorporado.

Nesta direção, foi possível problematizar o Direito Ambiental assinalando a restrição semântica do meio ambiente operada pela elaboração, interpretação conceitual e aplicações das leis ambientais. Em outras palavras, a natureza técnica na integração com o meio, bem como o assenhoramento simbólico realizado pelos grupos sociais, ambos na sua substância temporal e nas especificidades paisagísticas, são pouco - ou quase nada - considerados na doutrina e na jurisprudência, ficando $o$ meio ambiente preenchido e reduzido às suas características naturais. De certa forma, o Direito Ambiental confirma as impressões de Bartel e Graham (2013) quando dizem que o Direito possui concepções básicas dos problemas geográficos, a exemplo da relação do homem com o meio.

Vale lembrar, igualmente, a clausura operativa do sistema jurídico como percebido por Niklas Luhmann (VILLAS BOAS FILHO 2009; NEVES, 2009). Para o sociólogo, a disciplina jurídica opera segundo sua própria lógica interna de funcionamento, autorreferenciando-se sem recorrer a conceitos e julgamentos valorativos externos a ele. $\mathrm{Na}$ construção discursiva sobre o meio ambiente, apropriações jurídicas que extrapolem as conceituações do Direito Ambiental e tragam elementos valorativos de ordem geográfica (no sentido do ecúmeno adotado neste trabalho) são ignoradas e permanecem na margem das compreensões sobre meio ambiente. Mas talvez seja melhor limitar essas afirmações ao conjunto do material pesquisado já que exegeses extensivas e inclusivas do aspecto social poderiam ser encontradas na jurisprudência nacional.

De toda forma, um forte sentido (mediance) natural é introduzido nas relações com o meio, reorganizando valores pretéritos e os arranjos materiais paisagísticos em função da defesa dos ecossistemas naturais.

Nesta ordem de ideias, poder-se-ia ensaiar uma redefinição ou reinterpretação dos princípios de Direito Ambiental tentando incluir de alguma forma a esfera social, então, embora este não seja o escopo do trabalho. Destarte, poderse-ia falar em princípio do meio ambiente socioecologicamente equilibrado, significando a conservação das propriedades e funções naturais em harmonia e concordância com o implemento técnico e valorativo simbólico dos espaços onde se apresentam. 
O princípio da sadia qualidade de vida, por sua vez, pode ser entendido para além da manutenção da salubridade e das bases ecológicas do meio, incluindo também o respeito e adequação à natureza da integração ecumenal, nos seus diferentes níveis técnicos e apropriações simbólicas do meio onde vivem os homens, desde que não atentem contra princípios e direitos constitucionalmente protegidos.

Prevenir e precaver alcançaria não só danos aos processos e estruturas naturais mas também rupturas fundamentais nas relações técnico axiológicas com o meio, de forma a evitar desequilíbrios na relação do ecúmeno formado e perda de referência paisagística de existência da sociedade, garantindo justiça e equidade ambiental. É dizer que obras ou empreendimentos de grande porte devem resguardar as adaptações e conhecimentos sociais vinculados ao meio e que permitem a sobrevivência e desenvolvimento da comunidade.

Mais complicado, no âmbito deste trabalho, foi a observação da correspondência material do conjunto da doutrina e jurisprudência analisados. De fato, foi difícil capturar marcas antrópicas na paisagem a denunciar os desdobramentos da disciplina ambiental.

A dificuldade decorreu, em parte, da escolha do processo em torno do Paço Municipal para avaliações mais demoradas. Destarte, no estudo do processo judicial sobre o empreendimento, nenhuma forma antrópica concreta foi produzida na paisagem como resultado da ação levada a cabo pelo Ministério Público. Pelo contrário, houve inibição das intervenções da prefeitura que pudessem modificar o quadro natural existente, conquanto a decisão de mérito não reconheça nenhuma ilegalidade por parte do poder público.

O processo contribui, contudo, nas discussões sobre o "como a lei funciona" ("how law happens") mais do que sobre a "onde a lei incide" ("where of law") (BRAVERMAN, s/d).

$\mathrm{Na}$ literatura sobre a interdisciplinaridade entre Geografia e Direito, uma das tendências que podem ser identificadas nas pesquisas é a busca de formas ou padrões paisagísticos que são consequência dos mandamentos legais. Formas corresponderiam a normas, assim. Por um lado, procura-se formas produzidas diretamente pela atividade social, produto da transformação legalmente regulamentada do substrato material do espaço. O Direito age, nesse sentido, impondo modos de fazer, definindo o alcance espacial das intervenções e os limites das apropriações e modificações pretendidas. 
Mas, por outro lado, o Direito age também no sentido do não fazer, de proibir ações humanas transformadoras diretas sobre a paisagem. Seja sobre formas naturais, seja sobre formas construídas, o Direito coibe certas apropriações materialmente modificativas e nega a atuações ativas da sociedade sobre o meio.

No caso do processo sobre o Paço Municipal, o Direito atuou no sentido de preservação e manutenção das formas existentes e da paisagem em geral, embora, repita-se, a decisão final ateste pela legalidade das ações do poder público.

O processo nos mostra, contudo, este modus operandi do Direito: não foi rigorosamente uma lei que incidiu sobre a sub-bacia e proibiu ou impediu a instalação do Paço, mas um apoderamento jurídico que edificou simbolicamente a sub-bacia conforme seus atributos naturais, apoiando-se, ademais, em mapas (mapa de fraturas, mapa de zoneamento urbano), estudos técnicos (estudo hidrogeológico, estudo de impacto ambiental) e opinição de especialistas (audiências públicas).

A influência do Direito Ambiental na produção e formação da paisagem, portanto, é mais complexa que a simples incidência da lei sobre o espaço já que envolve outros momentos da operação interna do Direito, como a narração e valoração jurídica dos fatos geográficos dentro do processo associado com aporte de mapas e documentos técnicos que enquadram os fatos às categorias legalmente definidas (conceitos e princípios de Direito Ambiental) (BLOMLEY, 2008).

À guisa de conclusão, enfim, o Direito Ambiental participa da formação das paisagens não apenas na confluência direta das leis sobre determinadas áreas a definir formas (paisagem como marca), mas também atua na dimensão subjetiva da mediance das paisagens (paisagem como matriz) , acentuando sua esfera simbólica e fornecendo os parâmetros legais de sua apropriação. 


\section{REFERÊNCIAS}

ACOT, Pascal. História da ecologia. Trad. Carlota Gomes. Rio de Janeiro: Campus, 1990.

AKAL/DICCIONARIOS. Diccionario de geografía. Bajo la dirección de Pierre George. Madrid - Espanha: Ediciones Akal, 1991.

ANTAS JUNIOR, Ricardo Mendes. Território e regulação: espaço geográfico, fonte material e não formal do Direito. São Paulo: Associação Editorial Humanitas: Fapesp, 2005.

ANTUNES, Paulo de Bessa. Direito ambiental. 15 ed. São Paulo: Editora Atlas, 2013.

BARTEL, Robyn; GRAHAM, Nicole et al. Legal Geography: an Australian perspective. Geographical research. 51(4). Institute of Australian Geographers, 2013, 339-353.

BELTRÃO, Antonio F. G. Curso de Direito Ambiental. São Paulo: Elsevier/Método, 2009.

BERQUE, Augustin. Cinq propositions pour une théorie du paysage. Paris: Editions Champ Vallon, 1994.

. Écumène: introduction à l'étude des miliex humains. $2^{\underline{a}}$ ed. Paris: Belin, 2010.

Être humains sur la terre: principes d'étique de l'écoumène. Paris: Gallimard, 1996.

Médiance: de milieux en paysage. Paris: Belin/Reclus, 1990.

. Thinking through landscape. New York: Routledge, 2013.

BESSE, Jean-Marc. geografia e existência a partir da obra de Eric Dardel. In: DARDEL, Éric. O homem e a terra: natureza da realidade geográfica. Trad. Werther Holzer. São Paulo: Perspectiva, 2011. 
. Ver a terra: seis ensaios sobre a paisagem e a geografia. Trad. Vladimir Bartalini. São Paulo: Perspectiva, 2006.

BIRNFELD, Dionísio Renz. Dano moral ou extrapatrimonial ambiental. São Paulo: Ltr, 2009.

BLOMLEY, N.; DELANEY, D. FORD, R. The legal geographies reader: law, power, and space. Oxford:, Blackwell Publishers, 2001.

BLOMLEY, Nicholas; CLARK, Gordon.Law, theory, and geography. Urban Geography. 1990, V.11, 5, pp. 433-446. Disponível em: http://bellwether.metapress.com/content/0733m436v5563013/fulltext.pdf

BLOMLEY, Nicholas. From 'what' to 'só what': law ando geography in retrospect. In: HOLDER, J. HARRISON, Carolyn. Law and geography: current legal issues. V.5. New York: Oxford University Press, 2003.

BLOMLEY, Nicholas. Landscape of property. In: BLOMLEY, N.; DELANEY, D. FORD, R. The legal geographies reader: law, power, and space. Oxford:, Blackwell Publishers, 2001.

BLOMLEY, Nicholas. Simplification is complicated: property, naturem and the rivers of law. In: Environment and Planning A. 2008, V.40, pp. 1825-1842. Disponível em: http://www.sfu.ca/ blomley/swproxy.pdf

BOBBIO, Norberto. O positivismo jurídico: lições de filosofia do Direito. Compiladas por Nello Morra; trad. e notas Márcio Pugliesi, Edson Bini, Carlos E. Rodrigues. São Paulo: Ícone, 2006.

BONAVIDES, Paulo. Ciência Política. 20ª ed. São Paulo: Malheiros Editores, 2013.

BRASIL. Constituição (1988). Constituição da República Federativa do Brasil. Brasília, DF: Senado, 1988.

BRASIL. Lei no 6.938, de 31 de agosto de 1981. Dispõe sobre a Política Nacional do Meio Ambiente, seus fins e mecanismos de formulação e aplicação, e dá outras providências. Brasília, DF, 31 de agosto de 1981. Disponível em: 
<http://www.planalto.gov.br/ccivil 03/leis/L6938compilada.htm>. Acessado em: fevereiro 2014.

BRAVERMAN, Irus; BLOMLEY, Nicholas, DELANEY, David; KEDAR, Alexandre. The expanding spaces of law: a timely legal geography. Buffalo, Legal Studies Research Paper Series. Paper no 2013-032. Disponível em: http://ssrn.com/abstract=2235164.

CANOTILHO, José Joaquim Gomes. Estado Constitucional Ecológico e Democracia Sustentada. IN: FERREIRA, Heline Silvini; LEITE, José Rubens Morato (org). Estado de Direito Ambiental: tendências: aspectos constitucionais e diagnósticos. Rio de Janeiro: Forense Universitária, 2004.

CAROLINO, Ariella Kreitlon. O lugar do social na avaliação de impacto ambiental: regulação pública no Brasil, avanços teóricos e desafios para o planejamento regional. Dissertação (Mestrado) - Área de Concentração: Planejamento urbano e regional. FAUUSP. São Paulo, 2016.

CLAVAL, Paul. Epistemologia da geografia. $2^{a}$ ed. Trad. Margareth de Castro Afeche Pimenta e Joana Afeche Pimenta. Florianópolis: Ed. da UFSC, 2014.

COMIG. Projeto Hidrogeoambiental das Estâncias Hidrominerais da Companhia Mineradora de Minas Gerais. Belo Horizonte: 2001

CORDANI, Umberto G.; MARCOVITCH, Jacques and SALATI, Eneas. Avaliação das ações brasileiras após a Rio-92. Estud. av.[online]. 1997, vol.11, n.29, pp.399-408. ISSN 0103-4014. http://dx.doi.org/10.1590/S0103-40141997000100019.

CORRÊA, Roberto Lobato. A paisagem urbana brasileira: tipos ideais. GEOUSP Espaço e Tempo, São Paulo, v. 19, n. 1, p. 008-010, 2015.

CUNHA, Luís Henrique; COELHO, Maria Célia Nunes. Política e gestão ambiental. IN: CUNHA, Sandra Baptista da; GUERRA, Antonio José Teixeira (orgs). A questão ambiental: diferentes abordagens. 8르 ed. Rio de Janeiro: Bertrand Brasil, 2012. 
CUSTÓDIO, Helita Barreira. Direito ambiental e questões jurídicas relevantes. Campinas, SP: Millennium Editora, 2005.

CUSTÓDIO, Maraluce Maria. Conceito jurídico de paisagem: contribuições ao seu estudo no Direito brasileiro. Tese (doutorado em geografia) - UFMG, Instituto de Geociências, 2012.

DARDEL, Éric. O homem e a terra: natureza da realidade geográfica. Trad. Werther Holzer. São Paulo: Perspectiva, 2011.

DELANEY, David. Beyond the word: law as a thing of this world. In: HOLDER, J. HARRISON, Carolyn. Law and geography: current legal issues. V.5. New York: Oxford University Press, 2003.

DELANEY, David. Le jurique, le spatial et la pragmatique de la constrution de la réalité. In : FOREST, Patric. Géographie du droit: épistémologie, développement et perspectives. Canadá: Les presses de l'Université Laval, 2009.

DELANEY, David. The boundaries of responsibility: interpretations of geography in school desegregation cases. In: BLOMLEY, N.; DELANEY, D. FORD, R. The legal geographies reader: law, power, and space. Oxford: Blackwell Publishers, 2001.

DELGADO, José Augusto. Responsabilidade civil por dano moral ambiental. Informativo jurídico da biblioteca ministro Oscar Saraiva, v.19, n. 1, 2008.

DEMANGEON, Albert. Problemas de Geografía Humana. Traducción de Rocío de Terán. Barcelona: Ediciones Omega, 1942.

DERANI, Cristiane. Direito ambiental econômico. $2^{\underline{a}}$ ed. Prefácio de Eros Roberto Grau. São Paulo: Editora Max Limonad, 2001.

DIEGUES, A. C. Sant'Ana. O mito moderno da natureza intocada. $4^{a}$ ed. São Paulo: Hucitec: Núcleo de Apoio à Pesquisa sobre Populações Humanas e Áreas Úmidas Brasileiras, USP, 2004.

DINAMARCO, Cândido Rangel; CITRA, Antonio Carlos de Araújo; GRINOVER, Ada Pellegrini. Teoria geral do processo. 26 ed. rev. e atual. São Paulo: Ed. Malheiros, 2010. 
DINAMARCO, Cândido Rangel. Instituições de Direito procesual civil, $5^{\mathfrak{a}}$ ed. rev. e atual. De acordo com a emenda constitucional n 45, de 8.12.2004. São Paulo: Malheiros Editores, 2005.

DINIZ, Maria Helena. Compêndio de introdução à ciência do Direito. 16 ed. à luz da lei n. 10.406/02. São Paulo: Saraiva, 2004.

DREW, David. Processos interativos homem-meio ambiente. 9a ed. Trad. João Alves dos Santos. Rio de Janeiro: Bertrand Brasil, 2014.

EXATUS. Revisão do Plano Diretor do Município de Poços de Caldas: diagnóstico preliminar. Poços de Caldas: Secretaria de Planejamento e Coordenação, 2006.

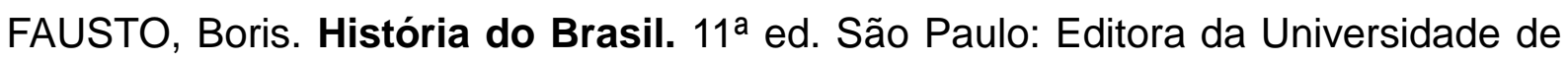
São Paulo, 2003.

FERIANI, Luiz Arlindo. Manual de Direito processual civil. Campinas: Bookseller, 2000.

FERREIRA, Aurélio Buarque de Holanda. Novo dicionário da língua portuguesa. $2^{\underline{a}}$ ed. 36 impressão. Rio de Janeiro: Editora Nova Fronteira, 1986.

FIORILlO, Celso Antonio Pacheco. Curso de Direito Ambiental brasileiro. 14 ed. rev. ampl. e atual. em face da Rio + 20 e do novo "Código" Florestal. São Paulo: Saraiva, 2013.

FORD, Richard T. The boundaries of race: political geography in legal analysis. In: BLOMLEY, N.; DELANEY, D. FORD, R. The legal geographies reader: law, power, and space. Oxford: Blackwell Publishers, 2001.

FOREST, Patric. Géographie du droit: épistémologie, développement et perspectives. Canadá : Les presses de I'Université Laval, 2009.

FRAXE, Jaiza Maria Pinto. Do geodireito ao conselho de gestão do patrimônio genético - CGEN: caminhos e instrumentos de gestão do conhecimento biotecnológico na Amazônia. Manaus: FUA, 2012. 
FRIEDMANN, Georges. 7 Estudos sôbre o homem e a técnica. Trad. Antonio Eduardo Vieira de Almeida e Eduardo de Oliveira e Oliveira. São Paulo: Difusão Européia do Livro, 1968.

GARCIER, Romain. Le droit et la fabrique de l'espace: aperçus méthodologiques sur l'usage des sources juridiques en géographie. In: FOREST, Patric. Géographie du droit : épistémologie, développement et perspectives. Canadá: Les presses de l'Université Laval, 2009.

GONÇALVES, Carlos Walter Porto. Os (des)caminhos do meio ambiente. 14를 ed. São Paulo: Contexto, 2010.

GORCIEX. Estudos ambientais para o Paço Municipal de Poços de Caldas. Volumes 1 e 2. Poços de Caldas, Secretaria Municipal de Planejamento, Desenvolvimento Urbano e Meio Ambiente; NUMAM - Núcleo de Meio Ambiente, 2010.

HARTSHORNE, Richard. Propósito e natureza da geografia. $2^{\underline{a}}$ ed. Trad.: Thomaz Newland Neto. São Paulo: Editora Hucitec: Editora da Universidade de São Paulo, 1978.

HOLDER, J. HARRISON, Carolyn. Law and geography: current legal issues. V.5. New York: Oxford University Press, 2003.

JAMIESON, Dale. Ética e meio ambiente: uma introdução. Trad. de André Luiz de Alvarenga. São Paulo: Editora Senac São Paulo, 2010.

LA BLACHE, Vidal de. A geografia Humana: suas relações com a geografia da Vida [1903]. In: HAESBAERT, Rogério; PEREIRA, Sérgio Nunes; RIBEIRO, Guilherme (orgs.). Vidal, vidais: textos de geografia humana, regional e política. Rio de Janeiro: Bertrand Brasil, 2012.

LA BLACHE, Vidal de. As condições geográficas dos fatos sociais [1902]. In: HAESBAERT, Rogério; PEREIRA, Sérgio Nunes; RIBEIRO, Guilherme (orgs.). Vidal, vidais: textos de geografia humana, regional e política. Rio de Janeiro: Bertrand Brasil, 2012. 
LA BLACHE, Vidal de. Aula inaugural do curso de geografia [1899]. IN: HAESBAERT, Rogério; PEREIRA, Sérgio Nunes; RIBEIRO, Guilherme (orgs.). Vidal, vidais: textos de geografia humana, regional e política. Rio de Janeiro: Bertrand Brasil, 2012.

LA BLACHE, Vidal de. Os gêneros de vida na geografia humana - segundo artigo [1911]. IN: HAESBAERT, Rogério; PEREIRA, Sérgio Nunes; RIBEIRO, Guilherme (orgs.). Vidal, vidais: textos de geografia humana, regional e política. Rio de Janeiro: Bertrand Brasil, 2012.

LA BLACHE, Vidal de. Prefácio ao Atlas Geral Vidal-LaBlache: História e geografia [1894]. IN: HAESBAERT, Rogério; PEREIRA, Sérgio Nunes; RIBEIRO, Guilherme (orgs.). Vidal, vidais: textos de geografia humana, regional e política. Rio de Janeiro: Bertrand Brasil, 2012.

LEFF, Enrique. Epistemologia ambiental. $5^{\underline{a}}$ ed. Trad. Sandras Valenzula. Rev. Téc. de Paulo Freire Vieira. São Paulo: Cortez, 2010.

LEFF, Enrique. Saber ambiental: sustentabilidade, racionalidade, complexidade, poder. $8^{a}$ ed. Trad. Lúcia Mathilde Endlich Orth. Petrópolis, RJ: Vozes, 2011.

LEITE, José Rubens Morato; AYALA, Patryck de Araújo. Dano ambiental: do individual ao coletivo extrapatrimonial. Teoria e prática. $7^{\underline{a}}$ ed. revista, atualizada e ampliada. São Paulo: Editora revista dos Tribunais, 2015.

LEITE, José Rubens Morato; PILATI, Luciana Cardoso; JUMANDÁ, Woldemar. Estado de Direito Ambiental no Brasil. In: KISHI, Sandra Akemi Shimida; SILVA, Solange Teles da; SOARES; Inês Virgínia Prado (org). Desafios do Direito Ambiental no século XXI: estudos em homenagem a Paulo Affonso Leme Machado. São Paulo: Malheiros Editores, 2005.

LEMOS, Pedro Sanches. As águas Thermaes de Poços de Caldas. Belo Horizonte: Imprensa Official do Estado de MG, 1904.

LENOBLE, Robert. História da ideia de natureza. Trad. Teresa Louro Pérez. Lisboa: Edições 70, 2002. 
LEOPOLD, Aldo. La ética de la tierra. In: VALDÉS, Margarida M. Naturaleza y valor: una aproximación a la ética ambiental. México, D.F.: UNAM, Instituto de Investigaciones Filosóficas, 2004.

LIRA, Larissa Alves. O primeiro esboço do método geográfico de Vidal de la Blache a partir dos estudos do Mediterrâneo. Permanências e rupturas no contexto da institucionalização da geografia (1872-1918). Dissertação (Mestrado em geografia). Faculdade de Filosofia, Letras e Ciências Humanas da Universidade de São Paulo. São Paulo, 2012.

MACHADO, Paulo Affonso Leme. Direito ambiental Brasileiro. 18 ${ }^{\underline{a}}$ ed. São Paulo: Malheiros Editores, 2010.

MARÍAS, Julián. História da filosofia. Prólogo de Xavier Zubiri; epílogo de José Ortega y Gasset. Trad. Claudia Berliner. São Paulo: Martins Fontes, 2004.

MARRAS, Stelio. A propósito de águas virtuosas: formação e ocorrência de uma estação balneária no Brasil. Belo Horizonte, Ed. UFMG, 2004.

MASSON, Cleber Rogério. Interesses Difusos e Coletivos - Esquematizado. 3. ed. São Paulo: Editora Método, 2013.

MAXIMILIANO, C. Hermenêutica e aplicação do Direito. 20ª ed. Rio de Janeiro: Forense, 2011.

MILARÉ, Édis. Direito do ambiente. 8o ed. rev. atual. e ampl. São Paulo: Editora Revista dos Tribunais, 2013.

MINAS GERAIS. Tribunal de Justiça, Agravo de Instrumento no 1.0400.05.0180738/001. Relator: Des. Mota da Silva. Comarca de Mariana, 7 de junho de 2006a. Disponível

em:

http://www5.tjmg.jus.br/jurisprudencia/pesquisaNumeroCNJEspelhoAcordao.do?num eroRegistro $=1$ \&totalLinhas $=1$ \&linhasPorPagina $=10$ \& numeroUnico $=1.0400 .05 .01807$ 3-8\%2F001\&pesquisaNumeroCNJ=Pesquisar. Acessado em: dezembro 2014.

MINAS GERAIS. Tribunal de Justiça, Agravo de Instrumento no 1.0400.07.0271293/001. Relator: Des. Alberto Vilas Boas. Comarca de Mariana, 21 de maio de 2008a. Disponível em: 
http://www5.tjmg.jus.br/jurisprudencia/pesquisaNumeroCNJEspelhoAcordao.do?num eroRegistro=1\&totalLinhas $=1$ \&linhasPorPagina=10\&numeroUnico=1.0400.07.02712 9-3\%2F001\&pesquisaNumeroCNJ=Pesquisar. Acessado em: dezembro 2014.

MINAS GERAIS. Tribunal de Justiça, Agravo de Instrumento no 1.0024.13.1297277/001. Relatora: Des. Ana Paula Caixeta. Comarca de Belo Horizonte, 1 de novembro de 2013c. Disponível em: http://www5.tjmg.jus.br/jurisprudencia/pesquisaNumeroCNJEspelhoAcordao.do?num eroRegistro=1\&totalLinhas=1 \&linhasPorPagina=10\&numeroUnico=1.0024.13.12972 7-7\%2F001\&pesquisaNumeroCNJ=Pesquisar. Acessado em: dezembro 2014.

MINAS GERAIS. Tribunal de Justiça, Apelação Cível no 1.0439.07.070302-0/001. Relator: Des. João Cancio. COMARCA DE MURIAÉ, 20 de abril de 2012a. Disponível

em:

http://www5.tjmg.jus.br/jurisprudencia/pesquisaNumeroCNJEspelhoAcordao.do;jsess ionid=C53F2A01606A4A2C47B5DAE26E49CFAC.juri node1 ? numeroRegistro=1\&tot alLinhas=1\&linhasPorPagina=10\&numeroUnico=1.0439.07.070302-

0\%2F001\&pesquisaNumeroCNJ=Pesquisar . Acessado em: agosto 2016.

MINAS GERAIS. Tribunal de Justiça, Apelação Civil no 1.0024.05.685939-0/001. Relator: Des. Caetano Levi Lopes. Comarca de Belo Horizonte, 9 de março de 2007a.

Disponível

em:

http://www5.tjmg.jus.br/jurisprudencia/pesquisaNumeroCNJEspelhoAcordao.do?num eroRegistro=1\&totalLinhas=1 \&linhasPorPagina=10\&numeroUnico=1.0024.05.68593 9-0\%2F001\&pesquisaNumeroCNJ=Pesquisar. Acessado em: janeiro 2015.

MINAS GERAIS. Tribunal de Justiça, Apelação Civil no 1.0086.11.001987-3/001. Relator: Des. Tiago Pinto. Comarca de Brasília de Minas, 21 de junho de 2013b. Disponível em: http://www5.tjmg.jus.br/jurisprudencia/pesquisaNumeroCNJEspelhoAcordao.do?num eroRegistro=1\&totalLinhas $=1$ \&linhasPorPagina $=10 \&$ numeroUnico $=1.0086 .11 .001987$ -3\%2F001\&pesquisaNumeroCNJ=Pesquisar. Acessado em: dezembro 2014.

MINAS GERAIS. Tribunal de Justiça, Apelação Civil/Reex Necessário no 1.0083.12.001095-0/001. Relatora: Des. Hilda Teixeira da Costa. Comarca de Borda da Mata, 21 de agosto de 2013a. Disponível em: 
http://www5.tjmg.jus.br/jurisprudencia/pesquisaNumeroCNJEspelhoAcordao.do?num eroRegistro $=1$ \&totalLinhas $=1$ \&linhasPorPagina $=10$ \&numeroUnico $=1.0083 .12 .00109$ 5-0\%2F001\&pesquisaNumeroCNJ=Pesquisar. Acessado em: janeiro 2015.

MINAS GERAIS. Tribunal de Justiça, Apelação Criminal no 1.0386.07.0070373/001. Relatora: Des. Beatriz Pinheiro Caires. Comarca de Lima Duarte, 30 de junho de 2014b.

Disponível

em:

http://www5.tjmg.jus.br/jurisprudencia/pesquisaNumeroCNJEspelhoAcordao.do?num eroRegistro=1\&totalLinhas=1 \&linhasPorPagina=10\&numeroUnico=1.0518.06.10593 4-2\%2F001\&pesquisaNumeroCNJ=Pesquisar. Acessado em: dezembro 2014.

MINAS GERAIS. Tribunal de Justiça. Apelação Cível nº 1.0518.11.011756-2/003. Relator: Des. Jair Varão. Comarca de Poços de Caldas, 04 de março de 2016. Disponível

em:

http://www5.tjmg.jus.br/jurisprudencia/pesquisaPalavrasEspelhoAcordao.do?\&numer oRegistro=1\&totalLinhas $=1$ \&paginaNumero=1 \&linhasPorPagina $=1$ \&palavras $=\mathrm{Pa} \% \mathrm{E}$ 70\%20Municipal\%20E\%20Po\%E7os\%20Caldas\&pesquisarPor=ementa\&pesquisaTe sauro=true\&orderByData=1\&referenciaLegislativa=Clique\%20na\%20lupa\%20para\% 20pesquisar\%20as\%20refer\%Eancias\%20cadastradas...\&pesquisaPalavras=Pesqui sar\&. Acessado em abril 2017.

MINAS GERAIS. Tribunal de Justiça, Apelação Criminal no 1.0518.06.1059342/001. Relator: Des. Herbert Carneiro. Comarca de Poços de Caldas, 18 de maio de 2011a. Disponível

em:

http://www5.tjmg.jus.br/jurisprudencia/pesquisaNumeroCNJEspelhoAcordao.do?num eroRegistro=1\&totalLinhas $=1$ \&linhasPorPagina=10\&numeroUnico=1 0518.06 .10593 4-2\%2F001\&pesquisaNumeroCNJ=Pesquisar. Acessado em: janeiro 2015.

MINAS GERAIS. Tribunal de Justiça, Apelação Criminal no 1.0879.08.0006569/001. Relator: Des. Marcílio Eustáquio Santos. Comarca de Carmópolis de Minas, 12 de março de 2014a. Disponível em: http://www5.tjmg.jus.br/jurisprudencia/pesquisaNumeroCNJEspelhoAcordao.do?num eroRegistro=1\&totalLinhas $=1$ \&linhasPorPagina $=10$ \& numeroUnico=1 0400.05 .01807 \&pesquisaNumeroCNJ=Pesquisar. Acessado em: dezembro 2014. 
MINAS GERAIS. Tribunal de Justiça, Mandado de Segurança no 1.0216.06.040037-3/001. Relator: Des. Nepomuceno Silva. Comarca de Diamantina, 21 de setembro de 2007b. Disponível em: http://www5.tjmg.jus.br/jurisprudencia/pesquisaNumeroCNJEspelhoAcordao.do?num eroRegistro $=1$ \&totalLinhas $=1$ \&linhasPorPagina $=10$ \& numeroUnico $=1.0216 .06 .04003$ 7-3\%2F001\&pesquisaNumeroCNJ=Pesquisar. Acessado em: janeiro 2015.

MINAS GERAIS. Tribunal de Justiça. Ação Cível Pública no 1.0024.03.1159783/001. Relator: Des. Geraldo Augusto. Comarca de Belo Horizonte, 18 de julho de 2008b.

Disponível

em:

http://www5.tjmg.jus.br/jurisprudencia/pesquisaNumeroCNJEspelhoAcordao.do?num eroRegistro=1\&totalLinhas $=1$ \&linhasPorPagina $=10$ \& numeroUnico=1.0024.03.115978 -3\%2F001\&pesquisaNumeroCNJ=Pesquisar. Acessado em: agosto 2016.

MINAS GERAIS. Tribunal de Justiça. Ação Civil Pública no 1.0024.13.3777391/001. Relator: Des. Raimundo Messias Júnior. Comarca de Belo Horizonte, 29 de outubro de 2015b. Disponível em: http://www5.tjmg.jus.br/jurisprudencia/pesquisaNumeroCNJEspelhoAcordao.do?num eroRegistro=1\&totalLinhas $=1$ \&linhasPorPagina=10\&numeroUnico=1.0024.13.37773 9-1\%2F001\&pesquisaNumeroCNJ=Pesquisar. Acessado em: agosto 2016.

MINAS GERAIS. Tribunal de Justiça. Apelação Cével $n^{\circ}$ 1.0024.03.131618-5/001. Relator: Des. Geraldo Augusto. Comarca de Belo Horizonte, 10 de fevereiro de 2006b. Disponível

em: http://www5.tjmg.jus.br/jurisprudencia/pesquisaNumeroCNJEspelhoAcordao.do?num eroRegistro=1\&totalLinhas $=1$ \&linhasPorPagina $=10$ \& numeroUnico=1.0024.03.13161 8-5\%2F001\&pesquisaNumeroCNJ=Pesquisar. Acessado em: agosto 2016.

MINAS GERAIS. Tribunal de Justiça. Apelação Cível $\mathbf{n}^{\circ}$ 1.0132.05.002117-0/001. Relator: Des. Carreira Machado. Comarca de Carandaí, 22 de outubro de 2008e. Disponível em: http://www5.tjmg.jus.br/jurisprudencia/pesquisaNumeroCNJEspelhoAcordao.do?num eroRegistro=1\&totalLinhas $=1$ \&linhasPorPagina $=10$ \& numeroUnico $=1.0132 .05 .002117$ -0\%2F001\&pesquisaNumeroCNJ=Pesquisar. Acessado em: agosto 2016. 
MINAS GERAIS. Tribunal de Justiça. Apelação Cível no 1.0024.03.971351-6/001. Relator: Des. Geraldo Augusto. Comarca de Belo Horizonte, 24 de junho de 2008d. Disponível em: http://www5.tjmg.jus.br/jurisprudencia/pesquisaNumeroCNJEspelhoAcordao.do?num eroRegistro=1\&totalLinhas $=1$ \&linhasPorPagina $=10$ \& numeroUnico=1.0024.03.97135 1-6\%2F001\&pesquisaNumeroCNJ=Pesquisar. Acessado em: agosto 2016.

MINAS GERAIS. Tribunal de Justiça. Apelação Cível nº 1.0024.05.700750-2/001. Relator: Des. Mauro Soares de Freitas. Comarca de Belo Horizonte, 14 de agosto de 2008c. Disponível

em:

http://www5.tjmg.jus.br/jurisprudencia/pesquisaNumeroCNJEspelhoAcordao.do?num eroRegistro=1\&totalLinhas $=1$ \&linhasPorPagina=10\&numeroUnico=1.0024.05.70075 0-2\%2F001\&pesquisaNumeroCNJ=Pesquisar. Acessado em: agosto 2016.

MINAS GERAIS. Tribunal de Justiça. Apelação Cível nº 1.0024.06.069158-1/001. Relator: Des. Luiz Artur Hilário. Comarca de Belo Horizonte, 11 de dezembro de $2015 a$.

em:

http://www5.tjmg.jus.br/jurisprudencia/pesquisaNumeroCNJEspelhoAcordao.do?num eroRegistro=1\&totalLinhas=1\&linhasPorPagina=10\&numeroUnico=1.0024.06.06915 8-1\%2F001\&pesquisaNumeroCNJ=Pesquisar. Acessado em: agosto 2016.

MINAS GERAIS. Tribunal de Justiça. Apelação Cível no 1.0132.05.001724-4/001. Relator: Des. Brandão Teixeira. Comarca de Carandaí, 1 de julho de 2013d. Disponível

em:

http://www5.tjmg.jus.br/jurisprudencia/pesquisaNumeroCNJEspelhoAcordao.do?\&nu $\underline{\text { meroRegistro }=2 \& \text { totalLinhas }=2 \text { \&paginaNumero }=2 \text { \&linhasPorPagina }=1 \text { \&numeroUnic }}$

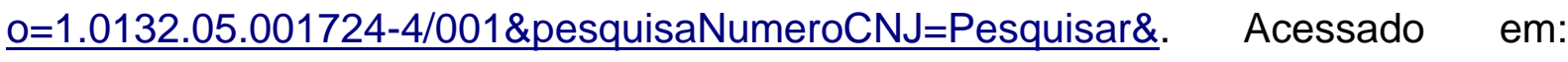
agosto 2016.

MINAS GERAIS. Tribunal de Justiça. Apelação Cível no 1.0388.03.004015-7/001. Relator: Des. (a) Tereza Cristina da Cunha Peixoto. Comarca de Luz, 4 de dezembro de 2012d. Disponível em: http://www5.tjmg.jus.br/jurisprudencia/pesquisaNumeroCNJEspelhoAcordao.do?num eroRegistro=1\&totalLinhas=1 \&linhasPorPagina=10\&numeroUnico=1.0388.03.00401 5-7\%2F001\&pesquisaNumeroCNJ=Pesquisar. Acessado em: agosto 2016. 
MINAS GERAIS. Tribunal de Justiça. Apelação Cível no 1.0625.11.003277-2/002. Relator: Des. (a): Vanessa Verdolim Hudson Andrade. Comarca de São João DelRei, 28 de maio de 2014c. Disponível em: http://www5.tjmg.jus.br/jurisprudencia/pesquisaNumeroCNJEspelhoAcordao.do?num eroRegistro $=1$ \&totalLinhas $=1$ \&linhasPorPagina $=10$ \& numeroUnico $=1.0625 .11 .003277$ -2\%2F002\&pesquisaNumeroCNJ=Pesquisar. Acessado em: agosto 2016.

MINAS GERAIS. Tribunal de Justiça. Apelação Cível no 1.0701.09.260144-5/001. Relator: Des. Belizário de Lacerda. Comarca de Uberaba, 22 de agosto de 2014e. Disponível

em:

http://www5.tjmg.jus.br/jurisprudencia/pesquisaNumeroCNJEspelhoAcordao.do?num eroRegistro=1\&totalLinhas $=1$ \&linhasPorPagina $=10$ \&numeroUnico=1.0701.09.26014 4-5\%2F001\&pesquisaNumeroCNJ=Pesquisar. Acessado em: agosto 2016.

MINAS GERAIS. Tribunal de Justiça. Apelação Cível no 1.0702.09.604039-0/001. Relator: Des. Armando Freire. Comarca de Uberlândia, 6 de julho de 2012c. Disponível em: http://www5.tjmg.jus.br/jurisprudencia/pesquisaNumeroCNJEspelhoAcordao.do?num eroRegistro=1\&totalLinhas=1\&linhasPorPagina=10\&numeroUnico=1.0702.09.60403 9-0\%2F001\&pesquisaNumeroCNJ=Pesquisar. Acessado em: agosto 2016.

MINAS GERAIS. Tribunal de Justiça. Apelação Cível no 1.0702.10.005258-9/003. Relator: Des. Luís Carlos Gambogi. Comarca de Uberlândia, 23 de setembro de $2013 e$. Disponível

em:

http://www5.tjmg.jus.br/jurisprudencia/pesquisaNumeroCNJEspelhoAcordao.do?num eroRegistro=1\&totalLinhas $=1$ \&linhasPorPagina $=10$ \& numeroUnico $=1.0702 .10 .00525$ 8-9\%2F003\&pesquisaNumeroCNJ=Pesquisar. Acessado em: agosto 2016.

MINAS GERAIS. Tribunal de Justiça. Apelação Cível no 1.0702.11.041283-1/001. Relator: Des. Corrêa Junior. Comarca de Uberlândia, 6 de junho de $2014 f$. Disponível em: http://www5.tjmg.jus.br/jurisprudencia/pesquisaNumeroCNJEspelhoAcordao.do?num eroRegistro=1\&totalLinhas $=1$ \&linhasPorPagina $=10 \&$ numeroUnico=1 0702.11 .041283 -1\%2F001\&pesquisaNumeroCNJ=Pesquisar. Acessado em: agosto 2016. 
MINAS GERAIS. Tribunal de Justiça. Apelação Cível no 1.0702.11.045745-5/001. Relator: Des. Renato Dresch. Comarca de Uberlândia, 25 de novembro de 2015c. Disponível em: http://www5.tjmg.jus.br/jurisprudencia/pesquisaNumeroCNJEspelhoAcordao.do?num eroRegistro $=1$ \&totalLinhas $=1$ \&linhasPorPagina $=10$ \& numeroUnico=1.0702.11.045745 -5\%2F001\&pesquisaNumeroCNJ=Pesquisar. Acessado em: agosto 2016.

MINAS GERAIS. Tribunal de Justiça. Apelação Cível nº 1.0702.96.002497-5/002. Relator: Des. Caetano Levi Lopes. Comarca de Uberlândia, 27 de agosto de 2004. Disponível

em:

http://www5.tjmg.jus.br/jurisprudencia/pesquisaNumeroCNJEspelhoAcordao.do?num eroRegistro=1\&totalLinhas $=1$ \&linhasPorPagina $=10$ \& numeroUnico=1 0702.96 .00249 7-5\%2F002\&pesquisaNumeroCNJ=Pesquisar. Acessado em: agosto 2016.

MINAS GERAIS. Tribunal de Justiça. Apelação Cível no 1.0103.06.000376-3/001. Relator: Des. (a). Teresa Cristina da Cunha Peixoto. Comarca de Caldas, 13 de fevereiro de

2012b. http://www5.tjmg.jus.br/jurisprudencia/pesquisaNumeroCNJEspelhoAcordao.do?num eroRegistro=1\&totalLinhas $=1$ \&linhasPorPagina $=10$ \& numeroUnico=1 0103.06 .00037 6-3\%2F001\&pesquisaNumeroCNJ=Pesquisar. Acessado em: agosto 2016.

MINAS GERAIS. Tribunal de Justiça. Embargo de Declaração no 1.0132.06.003144-1/002. Relator: Des. Edgard Penna Amorim. Comarca de Carandaí, 29 de setembro de 2014d. Disponível em: http://www5.tjmg.jus.br/jurisprudencia/pesquisaNumeroCNJEspelhoAcordao.do?\&nu $\underline{\text { meroRegistro }=2 \& \text { totalLinhas }=2 \text { \&paginaNumero }=2 \text { \&linhasPorPagina }=1 \text { \& numeroUnic }}$

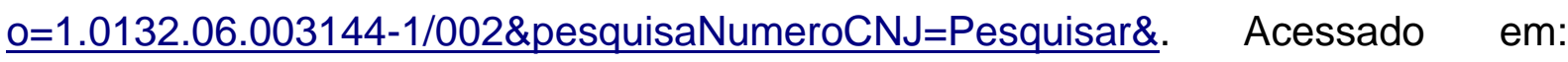
agosto 2016.

MINAS GERAIS. Tribunal de Justiça. Recurso em sentido estrito no 1.0702.09.598762-5/001. Relator: Des. Herbet Carneiro. Comarca de Uberlândia, 27 de janeiro de 2010.2 Disponível em: http://www5.tjmg.jus.br/jurisprudencia/pesquisaNumeroCNJEspelhoAcordao.do?num eroRegistro=1\&totalLinhas $=1$ \&linhasPorPagina=10\&numeroUnico=1 0702.09 .59876 2-5\%2F001\&pesquisaNumeroCNJ=Pesquisar. Acessado em: agosto 2016. 
MORAES, Antonio Carlos Robert. Ideologias geográficas. São Paulo: Annablume, 2005.

MORAES, Antonio Carlos Robert. Território e história no Brasil. 3 Ed. São Paulo, Annablume, 2008.

MOREIRA NETO, Diogo de Figueiredo. Introdução ao Direito ecológico e ao Direito Urbanístico. Instrumentos jurídicos para um futuro melhor. Rio de Janeiro São Paulo: Forense, 1975.

NAESS, Arne. La crisis del medio ambiente y el movimento ecológico profundo. In: VALDÉS, Margarida M. Naturaleza y valor: una aproximación a la ética ambiental. México, D.F.: UNAM, Instituto de Investigaciones Filosóficas, 2004.

NALINI, José Renato. Ética ambiental. 4a ed. rev. atual. e ampl. São Paulo: Editora Revista dos Tribunais, 2015.

NARDY, A. J. F. Uma leitura transdisciplinar do princípio da precaução. In: SAMPAIO, J. A. L.; WOLD, C.; NARDY, A. J. F. Princípios de Direito Ambiental. Belo Horizonte: Del Rey: 2003. p.117-249.

NASCIMENTO E SILVA, Geraldo Eulálio do. Direito ambiental Internacional: meio ambiente, desenvolvimento sustentável e os desafios da nova ordem mundial: uma reconstituição da Conferência do Rio de Janeiro sobre o meio ambiente e desenvolvimento. Rio de Janeiro: Thex Ed.: Biblioteca Estácio de Sá, 1995.

NEVES, Marcelo. Niklas Luhmann: "Eu vejo o que tu não vês". In: Jorge de Almeida e Wolfang Bader (Org.). Pensamento alemão no século XX. Vol. I. São Paulo: Ed. Cosac Naif, 2009.

NORTHROP, F. S. C. Man's relation to the Earth in its bearing on his aesthetic, ethical, and legal values. In: THOMAS, Willian L. Man's role in changing the face of the earth. Chicago: The University of Chicago Press, 1956.

PÁDUA, José Augusto (org). et al. Ecologia e política no Brasil. Rio de Janeiro: Espaço e Tempo: IUPERJ, 1987. 
PÁDUA, José Augusto. Natureza e sociedade no Brasil monárquico. In: SALLES, Ricardo; GRINBERG, Keila. O Brasil imperial, volume III: 1870-1889. Rio de Janeiro: Civilização Brasileira, 2009.

PERRET, Jean Marie. Pour une géographie juridique. Ánnales de géographie. 1994, t.103, ํo 579. pp. 520-526. Disponível em: http://www.persee.fr/web/revues/home/prescript/article/geo 000340101994 num 10357913809

PHILIPPI JR; Arlindo; RODRIGUES, José Eduardo R. Uma introdução ao Direito Ambiental: conceitos e princípios. In: PHILIPPI JR, A.; ALVES, Alaôr Caffé. Curso interdisciplinar de Direito Ambiental. Barueri - SP: Manole, 2005, p. 3-26.

PLANO DIRETOR. Poços de Caldas: Secretaria de Planejamento e Coordenação, março de 1992.

PLATT, R. H. Land use and society: geography, law and public policy.Washington: Island Press, 2004.

PLATT, R. H. Land use control: interface of law and geography. Washington: Association of American Geographers, 1976.

POÇOS DE CALDAS. Comissão Especial. Poços de Caldas, 2006. Documento disponível no arquivo público da Prefeitura de Poços de Caldas.

POÇOS DE CALDAS. Comissão técnica de parcelamento, uso e ocupação do solo e planejamento urbano. Poços de Caldas, 2006. Documento disponível no arquivo público da Prefeitura de Poços de Caldas.

POÇOS DE CALDAS. Decreto municipal o 8.536, de 8 de agosto de 2006. Dispõe sobre a definição de área para instalação do futuro Paço Municipal. Poços de Caldas, MG. Jornal de Poços, ed. № 2485, de 8 de agosto de 2006.

POÇOS DE CALDAS. Lei 3.639 de 4 de janeiro de 1985. Dispõe sobre o Parcelamento do Solo Urbano no Município de Poços de Caldas e dá outras providências. Mensagem no 00110/84. Arquivos da Câmara Municipal de Poços de Caldas. Consulta: junho 2011. 
POÇOS DE CALDAS. Lei Complementar n 5.488, de 30 de dezembro de 1993. Aprova o Plano Diretor do Município de Poços de Caldas e dá outras providências. Jornal da Cidade, Poços de Caldas, MG, 04 jan. 1994.

POÇOS DE CALDAS. Lei Complementar nำ 74, de 29 de dezembro de 2006. Dispõe sobre a revisão do Plano Diretor do Município de Poços de Caldas nos termos da Lei Federal n. 10.257/2001, altera, revoga e acrescenta dispositivos à Lei 5488, de 4 de janeiro de 1.994 e dá outras providências. Poços de Caldas, MG. Jornal de Poços, de 29 de dezembro de 2006.

POÇOS DE CALDAS. Lei Complementar no 84, de 26 de julho de 2007. Altera os Anexos I, II e III de que trata o Art. $2^{\circ}$ da Lei Complementar n. 74, de 29/12/2006 e fixa o novo perímetro urbano para o município de Poços de Caldas, com base na Lei Complementar n. 74, de 29 de dezembro de 2006, que "Dispõe sobre a revisão do Plano Diretor do Município de Poços de Caldas e dá outras providências". Poços de Caldas, MG. Jornal de Poços, de 26 de julho de 2007.

POÇOS DE CALDAS. Lei no 157 de 30 de setembro de 1921. Autoriza o Prefeito municipal a organizar plantas de habitações higiênicas. Livro de Leis do Conselho Deliberativo - 1918 a 1929. Localizado no Arquivo Público da Câmara Municipal de Poços de Caldas.

POÇOS DE CALDAS. Lei no 157 de 30 de setembro de 1921. Autoriza o Prefeito municipal a organizar plantas de habitações higiênicas. Livro de Leis do Conselho Deliberativo - 1918 a 1929. Localizado no Arquivo Público da Câmara Municipal de Poços de Caldas.

POÇOS DE CALDAS. Lei no 2.056 de 12 de maio de 1973. Fixa os objetivos e as diretrizes básicas do Plano Urbanístico de Poços de Caldas. Diário de Poços de Caldas, 12 de maio de 1973.

POÇOS DE CALDAS. Plano de Desenvolvimento Integrado - PDI. 1970/1971. 6 Volumes. Poços de Caldas: Consultec, 1970/1971.

POÇOS DE CALDAS. Plano de Desenvolvimento Integrado: Diagnóstico Preliminar - 1968. 2 Volumes. Poços de Caldas: Consultec, 1968, p. 2-153. 
PONTING, Clive. Uma história verde do mundo. Trad. Ana Zelma Campos. Rio de Janeiro: Civilização Brasileira, 1995.

PRADO JUNIOR, Caio. Formação do Brasil contemporâneo: colônia. São Paulo: Brasiliense, 2008.

RATZEL, Friedrich. A relação entre o solo e o Estado - capítulo I: o Estado como organismo ligado ao solo. GEOUSP - Espaço e Tempo, São Paulo, no 29, pp. 5158, 2011.

REALE, Miguel. Filosofia do Direito. 20 ed. São Paulo: Saraiva, 2002.

REALE, Miguel. Lições preliminares de Direito. 25 ed. São Paulo: Saraiva, 2000.

REALE, Miguel. O Direito como experiência: introdução à epistemologia jurídica. $2^{a}$ ed. São Paulo: Saraiva, 1992.

RIBEIRO, Guilherme. geografia humana: fundamentos epistemológicos de uma ciência. IN: HAESBAERT, Rogério; PEREIRA, Sérgio Nunes; RIBEIRO, Guilherme (orgs.). Vidal, vidais: textos de geografia humana, regional e política. Rio de Janeiro: Bertrand Brasil, 2012.

RIVELLI, Elvino Antonio Lopes. Evolução da legislação ambiental no Brasil: políticas de meio ambiente, educação ambiental e desenvolvimento urbano. IN: PHILIPPI Jr, Arlindo; PELICIONI, Maria Cecília Focesi. Educação ambiental e sustentabilidade. Barueri, SP: Manole, 2005.

RONAI, Maurice. Paisagens II. GEOgraphia. Rio de Janeiro, v. 17, n. 34, pp. 2472612015.

ROTHENBURG, Walter Claudius. A Constituição Ecológica. In: KISHI, Sandra Akemi Shimida; SILVA, Solange Teles da; SOARES; Inês Virgínia Prado (org). Desafios do Direito Ambiental no século XXI: estudos em homenagem a Paulo Affonso Leme Machado. São Paulo: Malheiros Editores, 2005.

SÁ, Alcindo José de. Geografia do Direito: as normas como formas sócio-espaciais. $2^{\underline{a}}$ ed. Recife: Editora Universitária, 2013. 
SÁ, Alcindo José de. Perspectivas da Geografia do Direito em uma geografia filosófica. Praxis. 67, 2011.

SAMPAIO, Maria Fernanda de Oliveira; GUIDI, Marina Elvira; SANTOS, Clibson Alves dos. Análise morfométrica e revitalização da bacia hidrográfica do Ribeirão das Vargens de Caldas, Poços de Caldas - MG: uma contribuição ao planejamento urbano. Revista Interface (Porto Nacional), [S.I.], n. 11, jun. 2016. ISSN 24482064.

Disponível

em:

<https://sistemas.uft.edu.br/periodicos/index.php/interface/article/view/2145>. Acesso em: 10 maio 2017.

SANCHES, Luiz Antonio M. Ugeda. Geodireito e a divisão do trabalho. Dissertação (Mestrado em Direito). Pontifícia Universidade Católica de São Paulo, 2009.

SANCHES, Luiz Antonio M. Ugeda. O geodireito enquanto identificação do conteúdo Geográfico no Direito. Dissertação (Mestrado em geografia). Pontifícia Universidade Católica de São Paulo, 2010.

SANTILLI, Juliana. Socioambientalismo e novos direitos. São Paulo: Peirópolis, 2005.

SANTOS, José Nicolau dos. As migrações do Direito. Revista da Faculdade de Direito da UFPR, Paraná, v. 4, p. 307-322, 1956.

SANTOS, José Nicolau dos. Fundamentos da geografia Jurídica. Revista da Faculdade de Direito da UFPR, Paraná, v. 2, p. 174-261, 1954.

SANTOS, Milton. A natureza do espaço: técnica e tempo, razão e emoção. 4⿳亠丷a ed. São Paulo: Editora da Universidade de São Paulo, 2004.

SANTOS, Milton. Espaço e método. 5ª ed. São Paulo: Editora da Universidade de São Paulo, 2014.

SANTOS, Milton. Pensando o espaço do homem. São Paulo: Editora da Universidade de São Paulo, 2004a. 
SARAIVA, F. R. dos Santos. Novíssimo dicionário latino-português. $11^{\mathrm{a}}$ ed. Redigido segundo o Plano de L. Quicherat. Rio de Janeiro - Belo Horizonte: Livraria Garnier, 2000.

SEEMANN, Jörn. Friedrich Ratzel entre Tradições e Traduções. Terra Brasilis (Nova Série) [Online], 1 | 2012, posto online no dia 05 Novembro 2012, consultado o 24 Dezembro 2014. Disponível em: http://terrabrasilis.revues.org/180

SHAMIR, Ronen. Suspended in space: bedouins under the law of Israel. In: BLOMLEY, N.; DELANEY, D. FORD, R. The legal geographies reader: law, power, and space. Oxfor:,Blackwell Publishers, 2001.

SHOCKEY, Frank Clinton. Geography and the Rule of Law in the Making of Two American Indian Reservations: a Geographic Study of Law as a Social System. University of Minnesota, PhD.Dissertation in Philosophy , 2008. Disponível em http://conservancy.umn.edu/handle/91518 Último acesso: dezembro 2011.

SILVA, De Plácido e. Vocabulário Jurídico. 27ํㅡㄹ ed. Atualizadores: Nagib Slaibi Filho e Gláucia Carvalho. Rio de Janeiro: Companhia Editora Forense, 2008.

SILVA, José Afonso. Direito ambiental constitucional. $7^{\circ}$ ed. São Paulo: Malheiros Editores, 2009.

SILVA, P. B. da. Aspectos semiológicos do Direito do ambiente. Belo Horizonte: Del Rey, 2004.

SIRVINSKAS, Luís Paulo. Manual de Direito Ambiental. 14aㅗ ed. São Paulo: Saraiva, 2016.

SOARES, Paulo R. Rodrigues. LA DIFUSIÓN DEL HIGIENISMO EN BRASIL Y EL SANEAMIENTO DE PELOTAS (1880-1930). Scripta Nova. Universidad de Barcelona. № 69 (38), 2000.

SORRE, Max. El hombre em la tierra. Barcelona: Editorial Labor, 1967.

SORRE, Max. Les fondements de la géographie humaine. Tome I et II. Paris: Librarie Armand Colin, 1948. 
SOUZA SANTOS, Boaventura. Um discurso sobre as ciências. $7^{\underline{a}}$ ed. Porto: Afrontamento, 1995.

SOUZA, Jonas Dias de. A influência das leis municipais na estruturação da paisagem urbana da cidade de Poços de Caldas - Minas Gerais. Dissertação (Mestrado em geografia) - Faculdade de Filosofia, Letras e Ciências Humanas da Universidade de São Paulo. Departamento de geografia. São Paulo, 2012.

SPRIGGE, T. L. S. U. ¿Hay valores intrínsecos en la naturaleza? In: VALDÉS, Margarida M. Naturaleza y valor: una aproximación a la ética ambiental. México, D.F.: UNAM, Instituto de Investigaciones Filosóficas, 2004.

THEODORO JÚNIOR, Humberto. Curso de Direito Processual Civil - teoria geral do Direito processual civil e processo de conhecimento. 52 ed. Rio de Janeiro, 2011.

TISSIER, Jean Louis. Oekoumène. Hypergéo. Maio, 2004. Disponível em: <http://www.hypergeo.eu/spip.php?article302\#>. Acessado em: janeiro 2017.

TROPER, M. A filosofia do Direito. Trad. Ana Deiró. São Paulo: Martins, 2008.

VILLAS BÔAS FILHO, Orlando. Teoria dos sistemas e o Direito brasileiro. São Paulo: Saraiva, 2009.

VIOLA, Eduardo. O movimento ecológico no Brasil: do ambientalismo à ecopolítica. IN: PÁDUA, José Augusto (org). et al. Ecologia e política no Brasil. Rio de Janeiro: Espaço e Tempo: IUPERJ, 1987.

UGEDA, Luiz. Direito administrativo geográfico: fundamentos na geografia e na cartografia oficial do Brasil. Brasília: Geodireito, 2017.

WAINER, Ann Helen. Legislação ambiental brasileira: subsídios para a história do Direito Ambiental. Rio de Janeiro: Revista forense, 1999.

WEYERMÜLLER, André R. Direito Ambiental e aquecimento global. São Paulo: Atlas, 2010.

WHATMORE, Sarah. De/Re-territorializing possession: The shifting spaces of property rights. In: HOLDER, J. HARRISON, Carolyn. Law and geography: current legal issues. V.5. New York: Oxford University Press, 2003. 
WINTER, Gerd. A natureza jurídica dos princípios ambientais em Direito internacional, Direito da comunidade européia e Direito nacional. In: KISHI, Sandra Akemi Shimida; SILVA, Solange Teles; SOARES, Inês Virgínia Prado (org). Desafios do Direito Ambiental no século XXI: estudos em homenagem a Paulo Affonso Leme Machado. São Paulo: Malheiros, 2005, p. 120-150.

WORSTER, Donald. Nature's economy: a history of ecological ideas. $2^{\mathrm{a}}$ ed. Cambridge: Cambridge University Press, 1994. 